\title{
AVALIAÇÃO DA QUALIDADE DA ÁGUA DA BACIA DO ALTO JACARÉ-GUAÇU/SP (RIBEIRÃO DO FEIJÃO E RIO DO MONJOLINHO) ATRAVÉS DE VARIÁVEIS FÍSICAS, QUÍMICAS E BIOLÓGICAS
}

\section{MARLON PELÁEZ RODRÍGUEZ}

\begin{abstract}
Tese apresentada à Escola de Engenharia de São Carlos, Universidade de São Paulo, como parte dos requisitos para obtenção do título de Doutor em Ciências da Engenharia Ambiental.
\end{abstract}

Orientadora: Prof ${ }^{\mathrm{a}}$. Dr ${ }^{\mathrm{a}}$. TAKAKO MATSUMURA-TUNDISI

São Carlos 


\section{AGRADECIMENTOS}

À todas aquelas pessoas e instituições, que de uma forma ou de outra, colaboraram para a realização do presente trabalho, e também aquelas que facilitaram minha permanência no Brasil, em especial:

Ao Convênio Brasil-Colômbia (PEC-PGpela bolsa concedida.

À minha Orientadora Prof.a. Dra. Takako Matsumura-Tundisi e ao Prof. Dr. José Galizia Tundisi, pela oportunidade e confiança dadas, as quais permitiram a concretização de mais uma etapa na minha formação profissional.

Ao Prof. Dr. Evaldo Luíz Gaeta Espíndola pela revisão e sugestões dos Capítulos 1, 2 e 3 .

Ao Prof. Dr. Alberto Carvalho Peret pela análise estatística do Capítulo 3.

A Profa. Dra. Maria Olímpia de Oliveira Rezende que me agregou em seu laboratório brindando-me com a oportunidade de conhecer o mundo da química analítica, além da revisão dos Capítulos 4 e 5 .

A Profa. Dra. Susana Trivinho Strixino, pelo auxilio na identificação dos macroinvertebrados coletados, além da contribuição no desenvolvimento do capitulo 6 .

À Profa. Dra. Odete Rocha, pela constante colaboração durante o desenvolvimento da Tese.

Ao Prof. Dr. Marcelo Pereira de Souza, pela infra-estrutura cedida do Laboratório de Sistemas de Informação Geográfica (SIG) do Departamento de Hidráulica e Saneamento, para a digitalização e confecção dos diferentes mapas temáticos.

Ao SAAE de São Carlos, pela imagem de satélite cedida. 
Ao Químico Edson Copi do Instituto de Química de São Carlos/USP, pela colaboração na análise de metais.

Ao Marcelo Tavoni da Seção de Bolsas e Auxílios da EESC.

A Claudete, secretária do Programa de Pós-graduação em Ciências da Engenharia Ambiental e a Mara, bibliotecária do BICRHEA, pela colaboração prestada no decorrer deste trabalho.

Aos técnicos e funcionários do CRHEA/Departamento de Hidráulica e Saneamento (SHS)/EESC/USP.

Aos técnicos do Laboratório de Saneamento do SHS/EESC/USP.

Ao grupo de Radioquímica e Química Ambiental do Instituto de Química de São Carlos/USP.

Aos profissionais do Laboratório de Macroinvertebrados e Entomologia Aquática do Departamento de Hidrobiologia da UFSCar.

Aos técnicos e funcionários do Departamento de Ecologia e Biologia Evolutiva da UFSCar.

Aos colegas do Laboratório de Geoprocessamento/SHS/EESC/USP.

Aos amigos pela colaboração nos trabalhos de campo e laboratório, bem como pelo auxílio constante na utilização de recursos computacionais e na revisão dos textos, em especial a Corina, Donato, Sônia, Míriam, Leny, Eva, Alexandre, Antônio, William (Brasileiro), Mariana, Américo, Diogenes e William (Colombiano). 


\section{TABELAS}

Capítulo 1

pág.

Tabela I. Qualidade da água de um rio e maiores campos 3 científicos de estudo (MEYBECK, 1996).

\section{Capítulo 2}

Tabela I. Características dos pontos de amostragem, do 16 presente trabalho, no Alto Jacaré-Guaçu.

Tabela II. Porcentagem (\%) de matéria orgânica do sedimento 19 nos pontos de amostragem, nos dois períodos estudados, na bacia do Alto Jacaré-Guaçu.

Tabela III. Porcentagens de areia e fração fina (silte + argila) do 20 sedimento, dos pontos de amostragem, nos dois períodos estudados, da bacia do Alto Jacaré-Guaçu.

Capítulo 3

Tabela I. Classificação do estado trófico segundo o índice de Carlson, modificado.

Tabela II. Resultado das análises físicas e químicas da águanexo realizadas nos diferentes pontos de amostragem da bacia do Alto Jacaré-Guaçu em março/99.

Tabela III. Resultado das análises físicas e químicas da águanexo realizadas nos diferentes pontos de coleta da bacia do alto Jacaré-Guaçu em agosto/99.

Tabela IV. Hora da medição e temperatura da água na bacia 25 hidrográfica do Alto Jacaré-Guaçu.

Tabela V. Valores de turbidez (NTU), na bacia hidrográfica do 31 Alto Jacaré-Guaçu, nos dois períodos amostrados.

Tabela VI. Concentrações de carbono total e inorgânico (nh)g๕ 31 porcentagem do carbono inorgânico em relação ao total (\%), na bacia do Alto Jacaré-Guaçu, no período de março de 1999. 
Tabela VII. Valores de alcalinidade e dureza total da água, na 33 bacia hidrográfica do Alto Jacaré-Guaçu, em agosto de 1999.

Tabela VIII. Concentrações de carbono total e orgânico em (H)gL 36 e porcentagem do carbono orgânico em relação ao total (\%), na bacia hidrográfica do Alto Jacaré-Guaçu, em março de 1999.

Tabela IX. Valores de Demanda Química de Oxigênio, na bacia 38 hidrográfica do Alto Jacaré-Guaçu, em agosto de 1999.

Tabela X. Valores da Demanda Bioquímica de Oxigênio, na 39 bacia hidrográfica do Alto Jacaré-Guaçu, nos dois períodos estudados.

Tabela XI. Classificação do estado trófico, segundo o Índice de 46 Carlson, modificado, para o período chuvoso, na bacia do Alto Jacaré-Guaçu.

Tabela XII. Classificação do estado trófico, segundo o Índice de 46 Carlson, modificado, para o período seco, na bacia do Alto Jacaré-Guaçu.

Tabela XIII. Valores das variáveis analisadas no período das 49 chuvas na bacia do Alto Jacaré-Guaçu.

Tabela XIV. Valores das variáveis analisadas na análise de 51 componentes principais, para o período de inverno, na bacia do Alto Jacaré-Guaçu.

Tabela XV. Faixa de concentrações de íons dos principais rios do mundo, concentração natural mais comum (CNMC) e pontos amostrados no Alto Jacaré-Guaçu, sem influência urbana (M1, M2, F1, F2, F3, F4, F5, J1, J2, J3) e com influência (M3, M4 e M5), valores em $\mathrm{mgL}^{-1}$.

Tabela XVI. Valores de condutividade e nutrientes do Rio do 57 Monjolinho e Ribeirão do Feijão em coletânea de vários trabalhos na literatura para intercomparação com os resultados encontrados no presente trabalho. 
Capítulo 4

Tabela I. Concentração de metais na águanexo (mgL-1), em março/99 (chuva) e agosto/99 (seca), na bacia do Alto Jacaré-Guaçu.

Tabela II. Concentração de metais biodisponiveis no sedimeatrexo (mgL-1), em março/99 (chuva) e agosto/99 (seca), na bacia do Alto Jacaré-Guaçu.

Tabela III. Porcentagem referente à fração do conteúdo total de 79 metais do sedimento com potencial para ser incorporado pelos organismos e ordem decrescente de biodisponibilidade do metal, no período de estiagem de 1999, na bacia hidrográfica do Alto Jacaré-Guaçu.

Tabela IV. Concentração de metais biodisponiveis em 83 mgkg-1 de sedimento seco em coletânea de vários trabalhos na literatura para intercomparação com os resultados encontrados na bacia do Alto JacaréGuaçu.

\section{Capítulo 5}

Tabela I. Concentração de organoclorados na águạgL $\mathrm{L}^{-1}$ ), em anexo março/99 (chuva) e agosto/99 (seca), na bacia do Alto Jacaré-Guaçu.

Tabela II. Concentração máxima de organoclorado\$g( $\left.\mathrm{L}^{-1}\right)$ em coletânea de vários trabalhos na literatura para intercomparação com os resultados encontrados na bacia do Alto Jacaré-Guaçu.

\section{Capítulo 6}

Tabela I. Diagrama para determinação do Índice Biótico Belga 117 (IBB) com modificações (FONTURA, 1985 e TRIVINHO-STRIXINO \& NASCIMENTO, 2000).

Tabela II. Classificação de qualidade da água conforme o IBB. 
Tabela III. Famílias coletadas na bacia do Alto Jacaré-Guaçu e 119 seus respectivos valores de tolerância, segundo o método BMWP, com modificações.

Tabela IV. Classificação de qualidade da água conforme o 120 BMWP.

Tabela V. Valores indicativos de Porcentagem de Similaridade 121 (PSc) e sua respectiva classe de qualidade de água.

Tabela VI. Famílias de insetos aquáticos coletados na bacia do 122 Alto Jacaré-Guaçu nos períodos de estiagem e chuva de 1999.

Tabela VII. Géneros de Chironomidae (Diptera) coletados na 123 bacia do Alto Jacaré-Guaçu nos períodos de estiagem e chuva de 1999.

Tabela VIII. Outros macroinvertebrados aquáticos coletados na 124 bacia do Alto Jacaré-Guaçu nos períodos de estiagem e chuva de 1999.

Tabela IX. Classes de dominância dos diferentes táxons, naAnexo chuvas (Ch) e na Estiagem (Es), coletados na bacia.

Tabela X. Número de táxons e táxons eudominantes (>10) nos 125 pontos amostrados da bacia hidrográfica do Alto Jacaré-Guaçu, nos períodos de chuva e de estiagem de 1999.

Tabela XI. Valores dos índices de diversidade (Shannon), 128 Equitatividade (Pielou), Riqueza e Dominância (McNaughton), no período chuvoso ( $\mathrm{Ch}$ ) e de estiagem (Es) de 1999, na bacia do Alto Jacaré-Guaçu. 


\section{FIGURAS}

\section{Capítulo 2}

Figura 1. Localização da bacia hidrográfica do Alto JacaréGuaçu.

Figura 2. Tendências da precipitação pluviométrica e 11 temperatura do ar na bacia do Alto Jacaré-Guaçu, no período de agosto/98 a agosto/99.

Figura 3. Imagem de satélite da bacia hidrográfica do Alto 13 Jacaré-Guaçu, indicando, em vermelho, os pontos de amostragem.

Figura 4. Rede hidrográfica da bacia do Alto Jacaré-Guaçu 15 indicando os pontos de amostragem e suas respectivas áreas de drenagem.

\section{Capítulo 3}

Figura 1. Valores de $\mathrm{pH}$ da água, na bacia hidrográfica do Alto Jacaré-Guaçu, nos dois períodos amostrados.

Figura 2. Concentrações de oxigênio dissolvido, na bacia 29 hidrográfica do Alto Jacaré-Guaçu, nos dois períodos amostrados.

Figura 3. Valores de condutividade elétrica, na bacia 30 hidrográfica do Alto Jacaré-Guaçu, nos dois períodos amostrados.

Figura 4. Concentrações de materiais em suspensão 32 inorgânicos, na bacia hidrográfica do Alto JacaréGuaçu, nos dois períodos amostrados.

Figura 5. Concentrações de íons na água, na bacia hidrográfica 35 do Alto Jacaré-Guaçu, em agosto de 1999.

Figura 6. Concentrações de materiais em suspensão orgânicos, 37 na bacia hidrográfica do Alto Jacaré-Guaçu, nos dois períodos amostrados. 
Figura 7. Tendência das concentrações de nitrogênio orgânico 40 total, na bacia hidrográfica do Alto Jacaré-Guaçu, nos dois períodos amostrados.

Figura 8. Tendência das concentrações de amônia, na bacia 41 hidrográfica do Alto Jacaré-Guaçu, nos dois períodos amostrados.

Figura 9. Tendência das concentrações de nitrito, na bacia 43 hidrográfica do Alto Jacaré-Guaçu, nos dois períodos amostrados.

Figura 10. Tendência das concentrações de nitrato, na bacia 44 hidrográfica do Alto Jacaré-Guaçu, nos dois períodos amostrados.

Figura 11. Tendência das concentrações de fósforo total, na 45 bacia hidrográfica do Alto Jacaré-Guaçu, nos dois períodos amostrados.

Figura 12. Gráfico da análise de componentes principais, para o 47 período das chuvas, na bacia do Alto Jacaré-Guaçu.

Figura 13. Gráfico da análise de componentes principais,50 para o período de estiagem, na bacia do Alto Jacaré-Guaçu.

Capítulo 4

Figura 1. Concentração de chumbo (mgll), na bacia 67 hidrográfica do Alto Jacaré-Guaçu no período de chuvas.

Figura 2. Concentração de cobalto (mgL, na bacia 68 hidrográfica do Alto Jacaré-Guaçu no período de chuvas.

Figura 3. $\quad$ Concentração de cobre (mgll), na bacia hidrográfica do Alto Jacaré-Guaçu no período de chuvas.

$\begin{array}{lll}\text { Figura 4. Concentração de prata (mgll), na bacia hidrográfica } & 70\end{array}$ do Alto Jacaré-Guaçu no período de chuvas.

Figura 5. Concentração de ferro (mgl) na bacia hidrográfica do Alto Jacaré-Guaçu nos períodos de estudo. 
Figura 6. Concentração de manganês (mgI), na bacia 72 hidrográfica do Alto Jacaré-Guaçu nos períodos de estudo.

$\begin{array}{lll}\text { Figura 7. Concentração de zinco (mgL, na bacia hidrográfica } & 73\end{array}$ do Alto Jacaré-Guaçu nos períodos de estudo.

Figura 8. Concentração de chumbo potencialmente 74 biodisponível na bacia hidrográfica do Alto JacaréGuaçu.

Figura 9. Concentração de cobalto potencialmente 75 biodisponível na bacia hidrográfica do Alto JacaréGuaçu.

Figura 10. Concentração de cobre potencialmente biodisponível 75 na bacia hidrográfica do Alto Jacaré-Guaçu.

Figura 11. Concentração de cromo potencialmente biodisponível 76 na bacia hidrográfica do Alto Jacaré-Guaçu.

Figura 12. Concentração de ferro potencialmente biodisponível 76 na bacia hidrográfica do Alto Jacaré-Guaçu.

Figura 13. Concentração de manganês potencialmente 77 biodisponível na bacia hidrográfica do Alto JacaréGuaçu.

Figura 14. Concentração de níquel potencialmente biodisponível 77 na bacia hidrográfica do Alto Jacaré-Guaçu.

Figura 15. Concentração de prata potencialmente biodisponível 78 na bacia hidrográfica do Alto Jacaré-Guaçu.

Figura 16. Concentração de zinco potencialmente biodisponível 78 na bacia hidrográfica do Alto Jacaré-Guaçu.

\section{Capítulo 5}

Figura 1. Concentração de 4,4 DDE + Dieldrin, 4,4 DDD e 93 Metoxicloro na água $\mu\left(\mathrm{gL}^{-1}\right)$, na bacia hidrográfica do Alto Jacaré-Guaçu, nas chuvas (Ch) e na estiagem (Es) no presente estudo. 
Figura 2. Concentração de Aldrin, Endrin e Endrin-aldeído na 95 água ( $\left.\mu \mathrm{gL}^{-1}\right)$, na bacia hidrográfica do Alto JacaréGuaçu, nas chuvas (Ch) e na estiagem (Es) no presente estudo.

Figura 3. Concentração de alfa-endosulfan, beta-Endosulfan e 96 Endosulfan-sulfato na água $\left(\mathrm{gL}^{-1}\right)$, na bacia hidrográfica do Alto Jacaré-Guaçu, nas chuvas (Ch) e na estiagem (Es) no presente estudo.

Figura 4. Concentração de Heptacloro e Epóxido de heptacloro 98 na água ( $\left.\mu \mathrm{gL}^{-1}\right)$, na bacia hidrográfica do Alto JacaréGuaçu, nas chuvas (Ch) e na estiagem (Es) no presente estudo.

Figura 5. Concentração de alfa-HCH, gama-HCH e bata-HCH 99 na água $\left(\mu \mathrm{gL}^{-1}\right)$, na bacia hidrográfica do Alto JacaréGuaçu, nas chuvas (Ch) e na estiagem (Es) no presente estudo.

Figura 6. Concentração $\mathrm{HCB}$ e PCBs na água $\mu\left(\mathrm{gL}^{-1}\right)$, na bacia 100 hidrográfica do Alto Jacaré-Guaçu, nas chuvas (Ch) e na estiagem (Es) no presente estudo.

Capítulo 6

Figura 1. Mapa da qualidade da água, da bacia hidrográfica do 129 Alto Jacaré-Guaçu, classificada para o período de estudo, segundo o IBB.

Figura 2. Mapa da qualidade da água, da bacia hidrográfica do Alto Jacaré-Guaçu, classificada para o período de estudo segundo o BMWP.

Figura 3. Mapa da qualidade da água, da bacia hidrográfica do Alto Jacaré-Guaçu, classificada para o período de estudo segundo o Modelo de Porcentagem de Similaridade. 


\section{SUMÁRIO}

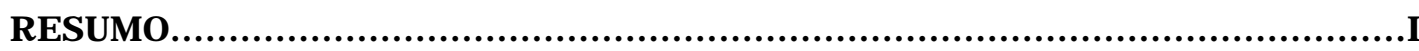

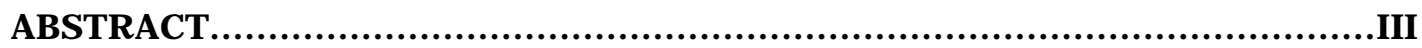

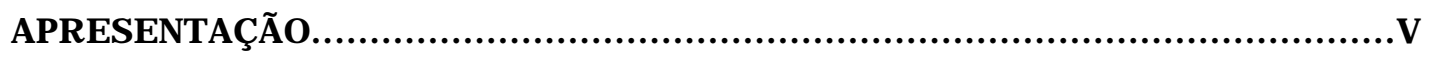

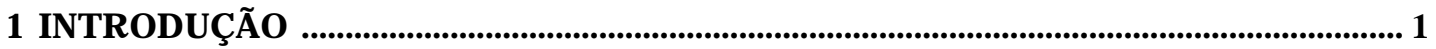

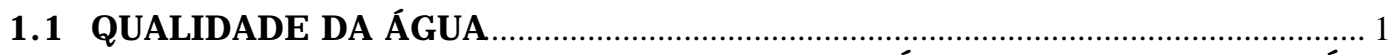

1.2 ESTUDOS REALIZADOS NA BACIA HIDROGRÁFICA DO ALTO JACARÉ

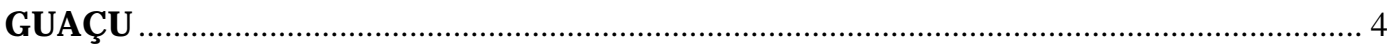

2 ÁREA DE ESTUDO E INFORMAÇÕES COMPLEMENTARES........................................... 8

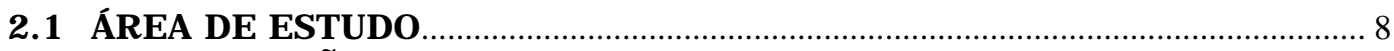

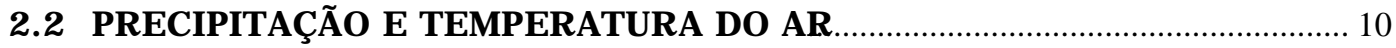

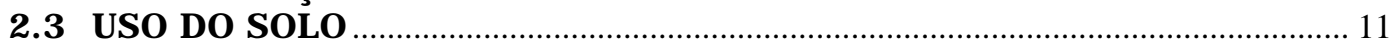

2.4 PERÍODO E PONTOS DE AMOSTRAGEM................................................................ 13

2.5 TEOR DE MATÉRIA ORGÂNICA E GRANULOMETRIA DO SEDIMENT.O.. 17

3 CARACTERÍZAÇÃO FÍSICA E QUÍMICA DA ÁGUA DA BACIA HIDROGRÁFICA

DO ALTO JACARÉ-GUAÇU ................................................................................................................ 20

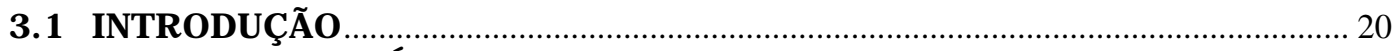

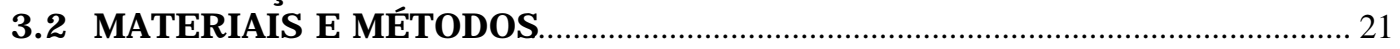

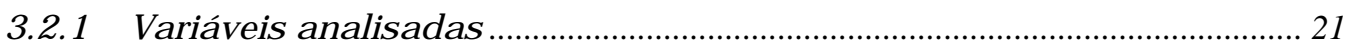

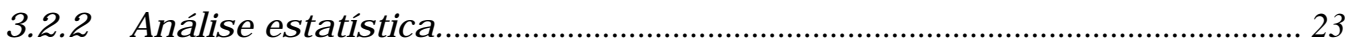

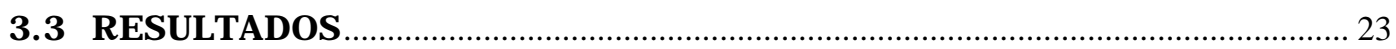

3.3.1 Temperatura da água, pH e concentração de oxigênio dissolvido............. 24

3.3.2 Variáveis que Indicam o balanço mineral: condutividade elétrica,

turbidez, material em suspensão inorgânico, alcalinidade, dureza e ions

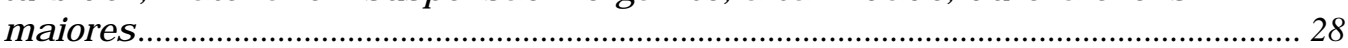

3.3.3 Variáveis que caracterizam a quantidade de matéria orgânica: carbono orgânico total, material em suspensão total, demanda química de oxigênio e

demanda bioquímica de oxigênio.............................................................................. 35

3.3.4 Variáveis indicadoras de eutrofização: nitrogênio Kjeldahl, amônia,

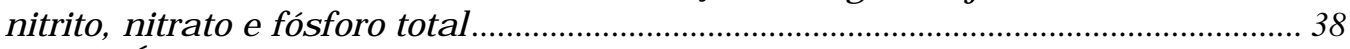

3.3.5 Índice do estado trófico.................................................................................... 45

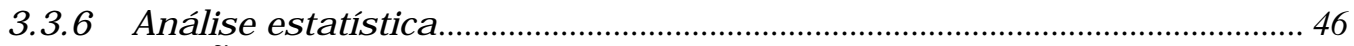

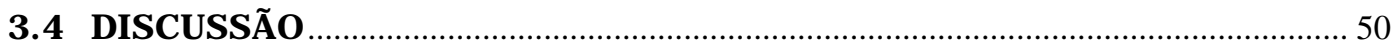

4 ANÁLISE DA CONTAMINAÇÃO POR METAIS NA BACIA HIDROGRÁFICA DO ALTO JACARÉ-GUAÇU ............................................................................................................ 58

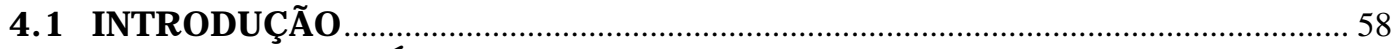

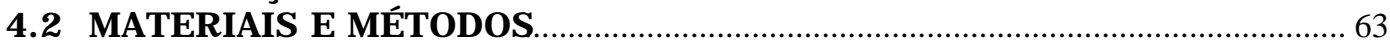

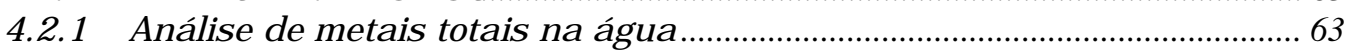

4.2.2 Análise de metais pesados no sedimento......................................................... 63

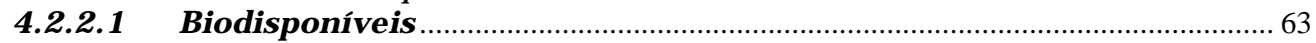

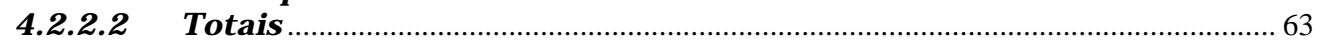

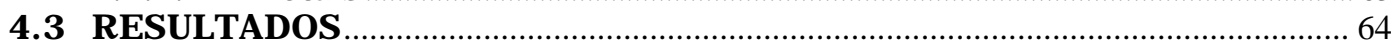

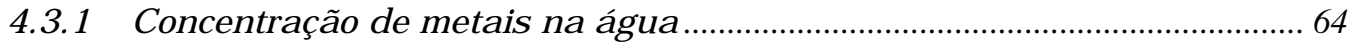

4.3.2 Análises no Sedimento …………………........................................................... 73

4.3.2.1 Biodisponiveis............................................................................................. 73

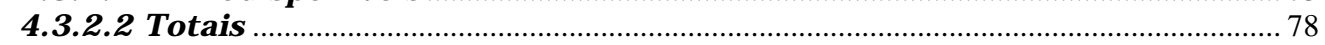

4.4 DISCUSSÃO 
5 ANÁLISE DE COMPOSTOS ORGANOCLORADOS (PESTICIDAS E BIFENILAS POLICLORADAS) NA BACIA DO ALTO JACARÉ-GUAÇU, SÃO PAULO....................... 84

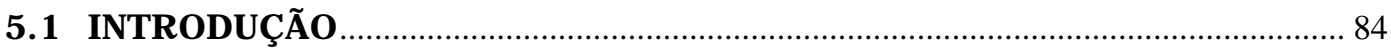

5.2 METODOLOGIA PARA A ANÁLISE DE COMPOSTOS ORGANOCLORADO\$7

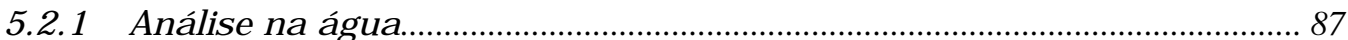

5.2.1.1 Amostragem coleta e estocagem da amostra ................................................8 87

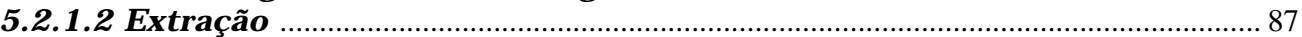

5.2.1.3 "Clean-up" e eluição …………………………………………………………….... 88

5.2.1.4 Determinação e quantificação ………………………………………………….... 88

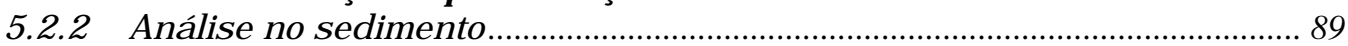

5.2.3 Determinação do conteúdo de umidade do sedimento por gravimetria... 91

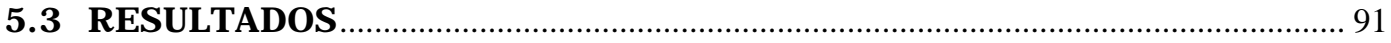

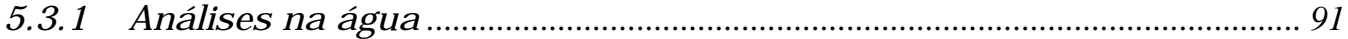

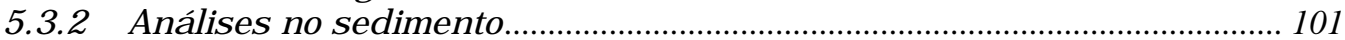

5.4 DISCUSSÃO

6 ANÁLISE DA COMUNIDADE DE MACROINVERTEBRADOS NA BACIA DO ALTO JACARÉ-GUAÇU (SP) ........................................................................................................................ 110

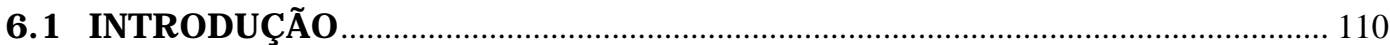

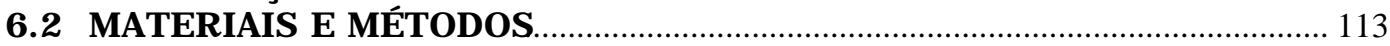

6.2.1 Amostragem, triagem e identificação......................................................... 113

6.2.2 Índices da estrutura da comunidade.......................................................... 114

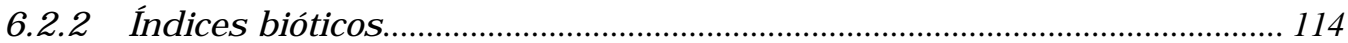

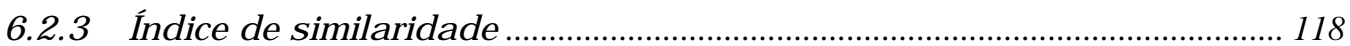

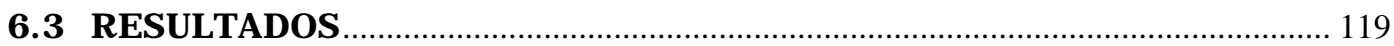

6.3.1 Estrutura taxonômica............................................................................. 119

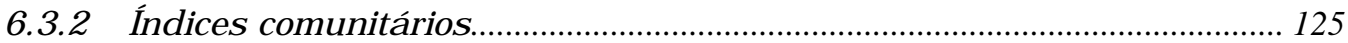

6.3.3 Índices bióticos.................................................................................. 127

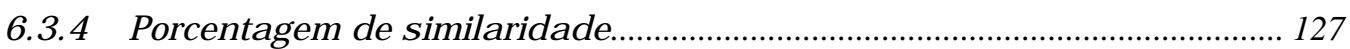

6.4 DISCUSSÃO

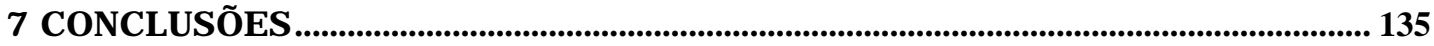

REFERÊNCIAS BIBLIOGRÁFICAS ................................................................................................. 139 


\section{RESUMO}

PELÁEZ-RODRÍGUEZ, M. Avaliação da qualidade da água da bacia do Alto Jacaré-Guaçu/SP (Ribeirão do Feijão e Rio do Monjolinho) através de variáveis físicas, químicas e biológicas. São Carlos, 2001. 147p. Tese (Doutorado). Escola de Engenharia de São Carlos, Universidade de São Paulo.

Os recursos hídricos urbanos são de grande importância para os municípios que têm desenvolvimento econômico crescente e aumento demográfico, sendo que a manutenção da qualidade da água dos mananciais de abastecimento para a população é imprescindível para a saúde e para diminuir o custo econômico. A bacia do Alto Jacaré-Guaçu, em cuja área está inserido o município de São Carlos/SP, tem como principais sub bacias a do Rio do Monjolinho e a do Ribeirão do Feijão, sendo este a principal fonte de abastecimento de água para a cidade.

O trabalho foi proposto para avaliar a qualidade da água dos recursos hídricos da bacia do Alto Jacaré-Guaçu, através da análise das características limnológicas, das substâncias tóxicas e da comunidade de macroinvertebrados que permitem a indicação da qualidade da água.

Foram efetuadas duas campanhas de amostragem em 1999: a) no período chuvoso (em março) e b) no período de estiagem (em agosto). Em março foram realizadas amostragens em 8 pontos e, em agosto, foram acrescidos mais 6 pontos, totalizando 14 . Paralelamente, com o intuito de visualizar espacialmente os resultados e desta forma identificar as áreas com maior ou menor grau de impacto, foi elaborado um mapa com as sub-bacias correspondentes às áreas cuja água drena para cada um dos pontos de coleta. 
Os resultados obtidos demonstram que a qualidade da água no período da estiagem se torna mais critica devido à diminuição do fluxo da água.

Com relação à poluição orgânica, a sub bacia do Monjolinho pode ser classificada em 3 grupos: atrecho sem influência urbana, portanto não poluída ou ligeiramente poluída; brecho com influência da área urbana da cidade de São Carlos, sendo assim, fortemente poluída e cltrecho final do Rio Monjolinho, com uma poluição moderada ou em processo de recuperação.

Quanto à presença de substâncias tóxicas analisadas as concentrações dos metais, em geral, apresentaram-se dentro dos limites da Resolução CONAMA 20/86, exceto o cobre, ferro, manganês e zinco. Já para os organoclorados, a maior parte da área da bacia não atende a Resolução Brasileira, detectando-se concentrações acima dos limites permitidos.

Quanto à identificação dos diferentes impactos no uso da terra e da água na bacia do Alto Jacaré-Guaçu, pode-se citar, entre as atividades antrópicas que vem acelerando o processo de degradação ambiental, principalmente a qualidade da água :1- Falta de tratamento do esgoto doméstico, principalmente na área urbana; 2Desmatamento contínuo levando a substituição da vegetação natural por monoculturas e pastagens; 3- Uso irregular do solo, causando erosão e assoreamento nos corpos de água; 4- Expansão sem controle da área urbana próximo às margens e principalmente nas nascentes dos corpos de água e 5-Falta de controle na comercialização e uso de defensivos agrícolas.

Palavras chave: Avaliação da qualidade da água, análises físicas e químicas das águas, metais traço, organoclorados e bioindicadores. 


\section{ABSTRACT}

PELÁEZ-RODRÍGUEZ, M. Evaluation of the water quality of Alto Jacaré-Guaçu Basin (Ribeirão do Feijão and Rio do Monjolinho), São Paulo State, by the physical, chemical and biological conditions. São Carlos, 2001. 147p. Ph.D. thesis. Escola de Engenharia de São Carlos, Universidade de São Paulo.

The water resources in urban areas are important for the municipalities in stage of economical development and demographic increase. The maintenance of quality of the water sources is indispensable for the human health and to reduce the economic costs. The Alto Jacaré-Guaçu basin, situated in São Carlos municipality, has as principal sub-basins the Monjolinho River and Ribeirão do Feijão basins. Both are the main source of water supply for the city.

This study was proposed to analyze the water quality of the Alto Jacaré-Guaçu basin, according to the limnological conditions, toxic substances and utilization of macroinvertebrates as indicative of the water quality.

Sampling was carried out in two periods: a) in the rainy season (March 1999) and b) in the dry season (August 1999). In March 8 stations were sampled, while in August 6 more stations were sampled, totalizing 14 stations. In parallel, a map was elaborated with the sub-basins corresponding to the drainage area for each station in order to show spatially the results and to identify the areas with bigger or minor degree of impact.

The results demonstrated that the water quality in the dry period became critical due to decreasing of the water flow.

Concerning to the organic pollution, the sub-basin of Monjolinho can be classified under 3 groups: a) section without 
urban influence, with no or few pollution; b) section with influence of the urban area of São Carlos city, being strongly contaminated and c) final section the Monjolinho River, with a moderate pollution or in process of recovery.

In relation to the presence of toxic substances analyzed, the concentrations of metals generally appeared inside the limits of the Resolution CONAMA 20/86, except for copper, iron, manganese and zinc. For the organochlorine pesticides, the concentrations observed do not attend to the Brazilian Resolution, because the values were higher than the acceptable limits.

Concerning to the identification of different impacts of the land and water uses in the Alto Jacaré-Guaçu basin, it is possible to identify the human activities that accelerate the process of environmental degradation, specially for the water quality: 1- The lack of treatment of the domestic residues, specially in the urban area; 2-Continuous deforestation and changing of natural vegetation to monocultures and pastures; 3-Irregular uses of the soil causing erosion and collapsing the water bodies; 4-Expansion without control of the urban area next to the margins and specially in the headwaters, and 5-Lack of control in the selling and uses of agricultural pesticides.

Key words: Evaluation of the water quality, physical and chemical analysis of waters, trace metals, organochlorine pesticides and bioindicators. 


\section{APRESENTAÇÃO}

Nos últimos anos muitos estudos têm sido realizados para investigar o problema da redução da qualidade da água para o abastecimento, lazer, irrigação, entre outros, levando à identificação das fontes poluidoras, bem como à elaboração de propostas para o seu controle, o que gera subsídios para programas de monitoramento da qualidade da água. Outra prática bastante utilizada é o estabelecimento de indicadores da qualidade da água (físicos, químicos e biológicos). PEDROSO,et al. (1988) relaciona as características das águas dos rios como sendo conseqüência do tipo de solo que atravessam em suas bacias de drenagem, cobertura vegetal e, principalmente, dos diversos tipos de ação antrópica.

Para uma melhor compreensão dos ecossistemas aquáticos é preciso avaliar a bacia hidrográfica onde está inserido o corpo de água, integrando e interagindo, simultaneamente, o ambiente aquático ao terrestre (LINKENS \& BORMANN, 1974). As bacias hidrográficas constituem paisagens ou unidades ambientais, nas quais todos os elementos naturais ou humanos se relacionam de maneira efetiva e inseparável. Nos últimos anos, os estudos de bacias hidrográficas têm-se destacado entre as pesquisas ambientais elaboradas dentro de uma visão holística do meio ambiente.

Nesse contexto, insere-se a importância do estudo na bacia hidrográfica do alto Jacaré-Guaçu, em cuja área está inserida a cidade de São Carlos/SP, o qual, apesar de ser considerada como relevante centro de pesquisa e tecnologia no Brasil, promove profundas alterações ambientais, decorrentes das atividades humanas, em seus corpos de água, como é o caso do Rio do Monjolinho, que tem como principal impacto o desenvolvimento urbano da cidade, e o Ribeirão do Feijão, que é a principal fonte de abastecimento de água para a cidade. 
Considerando-se os problemas derivados do processo de desenvolvimento da cidade, esta Tese tem como objetivo caracterizar física, química e biologicamente a bacia do alto Jacaré-Guaçu-SP (Ribeirão do Feijão e Rio do Monjolinho), visando o conhecimento do estado atual da qualidade da água e identificando os diferentes impactos no uso da terra e da água na bacia hidrográfica.

Para atender este objetivo e confirmar a hipótese de que os diferentes usos da terra e da água refletem nas características físicas e químicas e consequentemente, na biota da bacia hidrográfica, esta pesquisa foi desenvolvida com uma abordagem ecosistémica, considerando-se a bacia hidrográfica como unidade de estudo. Dentro desse escopo, coletas foram efetuadas para avaliação do sistema hídrico, acoplando-se informações sobre e uso do solo, além de dados da literatura existentes. Com as informações obtidas, procurou-se apresentar esta Tese em 7 capítulos, os quais abordam os seguintes tópicos:

- Capitulo 1: qualidade da água, formas de avaliação e síntese dos trabalhos desenvolvidos na bacia do Alto Jacaré-Guaçu.

- Capitulo 2: descrição da bacia do Alto Jacaré-Guaçu, com informações sobre clima da região, uso do solo e caracterização do sedimento.

- Capitulo 3: análises das características físicas e químicas da água em relação ao uso da bacia hidrográfica e comparação com os Padrões Brasileiros de Qualidade Ambiental (Resolução CONAMA $20 / 86)$.

- Capitulo 4: análise da contaminação da água por metais e comparação com os Padrões de Qualidade Ambiental (PQA). Além disso, apresentam-se os resultados das análises de metais nos sedimentos e sua possível disponibilidade para a coluna da água e/ou biota presente. 
- Capitulo 5: análise da contaminação da água e sedimento, por compostos organoclorados, relacionando-a com uso da bacia, comparando-a com os PQA da Legislação Brasileira.

- Capitulo 6: avaliação da qualidade da água através da análise da comunidade de macroinvertebrados em locais com diferentes usos da terra e da água, enfatizando aspectos como composição taxonômica, estrutura da comunidade e aplicação de índices bióticos e de similaridade.

- Capitulo 7: conclusões gerais do estudo.

Parte dos resultados desta Tese já foram apresentados em simpósios e similares, sendo publicados ou enviados à publicação:

- PElÁEZ-ROdRÍGUEZ, M.; PERET, A. M., MATSUMURA-TUNDISI, T. \& ROCHA, O.Análise da qualidade da água e aplicação do índice de proteção da vida aquática (IVA) em duas sub-bacias da bacia hidrográfica do Rio Jacaré-Guaçu. In: ESPÍNDOLA, et. al. 2000. ECOTOXICOLOGIA. Perspectivas para o Século XXI. São Carlos, RIMA, v.1. p. 95 - 114. 2000.

- PELÁEZ-RODRÍGUEZ, M., MATSUMURA-TUNDISI, T. \& REZENDE, M. O. de O. Análise de pesticidas organoclorados nos corpos de água das bacias hidrográficas do Rio Monjolinho e do Ribeirão do Feijão (Alto Jacaré-Guaçu, São Paulo). (aceito para publicação). In: Livro REPRESA DO LOBO-BROA 30 ANOS DE PESQUISA EM LIMNOLOGIA, GERENCIAMENTO E PARTICIPAÇÃO DA COMUNIDADE.

- PElÁEZ-RodrígueZ, M., TRIVINHOS-TRIXINO, S. \& MATSUMURA-TUNDISI, T. Avaliação da qualidade da água da bacia hidrográfica do alto Jacaré-Guaçu, (SP) através da 
comunidade de macroinvertebrados bentônicos. (aceito para publicação). In: Livro REPRESA DO LOBO-BROA 30 ANOS DE PESQUISA EM LIMNOLOGIA, GERENCIAMENTO E PARTICIPAÇÃO DA COMUNIDADE. 


\section{INTRODUÇÃO}

\subsection{QUALIDADE DA ÁGUA}

Os ecossistemas aquáticos acabam, de uma forma ou de outra, servindo como reservatórios temporários ou finais de uma grande variedade e quantidade de poluentes lançados no ar, no solo ou diretamente nos corpos de água. Desta forma, a poluição do ambiente aquático, provocada pelo homem, de uma forma direta ou indireta, através da introdução de substâncias inorgânicas ou orgânicas, produz efeitos deletérios tais como: I) prejuízo aos seres vivos, II) perigo a saúde humana, III) efeitos negativos as atividades aquáticas (pesca, lazer, etc.) e IV) prejuízo a qualidade da água com respeito ao uso na agricultura, indústria e outras atividades econômicas (MEYBECK \& HELMER, 1992).

Segundo MEYBECK \& HELMER (op. cit.), a qualidade de um ambiente aquático pode ser definida: I) segundo a presença de substâncias inorgânicas ou orgânicas em diferentes concentrações e especiações e II) segundo a composição e estrutura da biota aquática presente no corpo de água. A qualidade das águas superficiais depende do clima e do solo da região, da vegetação circundante, do ecossistema aquático e da influência do homem. Portanto, sofre variações temporais e espaciais em decorrência de processos internos e externos ao corpo de água.

Para BRANCO (1991), a expressão "qualidade da água” não se refere a um grau de pureza absoluto ou mesmo próximo do absoluto, mas sim a um padrão tão próximo quanto possível do "natural", isto é, tal como se encontra nas nascentes, antes do contato com o homem. Além disso, há um grau de pureza desejável, o qual depende 
do seu uso, que inclui abastecimento, irrigação, industrial, pesca, entre outros.

De acordo com MEYBECK \& HELMER (1992) a qualidade do ambiente aquático pode ser determinada através de medidas quantitativas, como determinações físicas e químicas (na água, no material particulado e nos organismos) e/ou testes bioquímicos/biológicos (medidas de $\mathrm{DBO}_{5}$, testes de toxicidade), ou através de medidas semiquantitativas e qualitativas, tais como índices bióticos, aspectos visuais, inventário de espécies, odor, etc. Estas determinações são realizadas no campo e no laboratório e produzem vários tipos de informações, fornecendo diferentes interpretações técnicas.

Em decorrência das múltiplas atividades humanas, crescentes exponencialmente, mais rios no mundo estão sendo impactados, inclusive aqueles que ficam longe das áreas industriais, por meio do transporte atmosférico de contaminantes. Estes impactos, nos sistemas aquáticos, podem ser considerados como um assunto de preocupação mundial. Atividades de monitoramento de rios estão crescendo rapidamente, particularmente sob pressão de organizações nacionais e internacionais, entre elas a Organização Mundial da Saúde (OMS), que dita uma série de padrões para a água potável. Como resultado, o número de descritores da qualidade da água excede normalmente mais de 100 (MEYBECK, 1996).

As análises químicas das águas tiveram início com o estudo do Lago Léman, feitas por TINGRY em 1808. FOREL, considerado o pai da Limnologia, também estudou as variações químicas do Alpine Rhone e, provavelmente, foi o primeiro a considerar o tempo como uma variável importante. Em 1924, com o compêndio CLARKE'S, de Geoquímica, nasce a era moderna da química das águas em escala mundial (MEYBECK, 1996). Desde FOREL, a caracterização das águas tem continuamente evoluído devido ao desenvolvimento, além 
da química analítica, de muitas outras ciências relacionadas com a água. Atualmente os estudos de qualidade da água relacionam-se a geociências, biociências e ciências da engenharia, como pode ser observado na Tabela I.

Tabela I. Qualidade da água de um rio e maiores campos científicos de estudo (MEYBECK, 1996).

\begin{tabular}{|c|c|c|c|c|}
\hline & & Campo & Tópico & Ponto de convergência \\
\hline $\begin{array}{l}\text { G } \\
E\end{array}$ & & \multirow[t]{3}{*}{ Geoquímica } & \multirow[t]{3}{*}{ Origens/processos } & $\begin{array}{l}\text { Influências do pH e do } \\
\text { potencial redox }\end{array}$ \\
\hline $\mathrm{O}$ & & & & $\begin{array}{l}\text { Especiação de compostos } \\
\text { traço }\end{array}$ \\
\hline I & & & & Dissolvidos vs. Particulados \\
\hline$\hat{\mathrm{E}}$ & & \multirow{3}{*}{$\begin{array}{l}\text { Geografia } \\
\text { Física }\end{array}$} & \multirow{3}{*}{$\begin{array}{l}\text { Taxas de transporte } \\
\text { Erosão química vs. } \\
\text { mecânica }\end{array}$} & Variações de elementos \\
\hline $\mathrm{N}$ & & & & maiores; Fluxos anuais, \\
\hline $\mathrm{C}$ & & & & Variações no regime de \\
\hline $\begin{array}{l}\mathrm{I} \\
\mathrm{A}\end{array}$ & & Hidrologia & $\begin{array}{l}\text { Decomposição } \\
\text { hidrográfica }\end{array}$ & transporte de traço químicos \\
\hline \multirow[t]{6}{*}{$\mathrm{S}$} & $\mathrm{B}$ & & & \\
\hline & $\begin{array}{l}\mathrm{I} \\
\mathrm{O} \\
\mathrm{C}\end{array}$ & Oceanografia & $\begin{array}{l}\text { Entradas aos oceanos e } \\
\text { mares }\end{array}$ & $\begin{array}{l}\text { Nutrientes; contaminantes; } \\
\text { matéria Orgânica;.fluxos } \\
\text { regional e global }\end{array}$ \\
\hline & $\mathrm{I}$ & Biogeoquímica & Ciclagem de nutrientes & Entradas de C, N, P, Si \\
\hline & $\begin{array}{l}\hat{\mathrm{E}} \\
\mathrm{N}\end{array}$ & & Interação biológica & $\begin{array}{l}\text { Deterioração da matéria } \\
\text { orgânica Ciclos do Fe, Mn e S }\end{array}$ \\
\hline & $\mathrm{C}$ & Hidrobiologia & Qualidade do ambiente & Faixas de concentrações \\
\hline & $\begin{array}{l}\mathrm{I} \\
\mathrm{A}\end{array}$ & & Qualidade extrema & Estrutura: tempo/espacial. \\
\hline $\mathrm{E}$ & $\mathrm{S}$ & Ecotoxicologia & $\begin{array}{l}\text { Bioacumulação } \\
\text { Biomagnificação }\end{array}$ & $\begin{array}{l}\text { Contaminantes; entradas e } \\
\text { especiações; Concentrações }\end{array}$ \\
\hline $\mathrm{N}$ & & & & extremas. \\
\hline \multicolumn{5}{|l|}{$\mathrm{G}$} \\
\hline $\begin{array}{l}\mathrm{E} \\
N\end{array}$ & & \multirow[t]{4}{*}{$\begin{array}{l}\text { Engenharia } \\
\text { Ambiental }\end{array}$} & $\begin{array}{l}\text { Padrões de Qualidade } \\
\text { da água }\end{array}$ & Estrutura tempo/espacial. \\
\hline $\mathrm{H}$ & & & Inventário de poluentes & Fontes difusas/pontuais \\
\hline A & & & Tendências & Fluxos e concentrações. \\
\hline $\mathrm{R}$ & & & Taxa de recuperação & Perfis longitudinais. \\
\hline I & & Engenharia & Erosão em leitos de rios & Níveis de SST. \\
\hline A & & Hidráulica & $\begin{array}{l}\text { Assoreamento de } \\
\text { reservatórios }\end{array}$ & Fluxos e regimes. \\
\hline
\end{tabular}




\subsection{ESTUDOS REALIZADOS NA BACIA HIDROGRÁFICA DO ALTO JACARÉ GUAÇU}

Entre os principais estudos desenvolvidos, quanto a qualidade da água, na bacia hidrográfica do Alto Jacaré-Guaçu, principalmente nas sub-bacias do Rio do Monjolinho e do Ribeirão do Feijão, tem-se:

SÉ (1992) estudou o Rio Monjolinho e sua bacia hidrográfica. Uma das conclusões que chegou o autor é que o Rio Monjolinho apresenta cinco (5) subsistemas característicos, submetidos a graus variados de intervenção antrópica. $\mathrm{O}$ primeiro subsistema possui uma menor ocupação e atividade; o segundo engloba a maior parte da ocupação e atividades urbanas da bacia (esgoto sanitário e industrial da cidade de São Carlos/SP); o terceiro apresenta sinais de recuperação da qualidade da água (vegetação nativa e pouca atividade humana); o quarto, a qualidade da água decaí novamente devido às atividades agro-industriais e ocupação rural, além da presença de lagoas de decantação de vinhoto, próximas ao rio e o quinto subsistema apresenta novamente sinais de depuração.

SANTOS (1993) estudou a bacia hidrográfica do Ribeirão do Feijão, dando uma abordagem teórica com ênfase nas fontes difusas de poluição e na caracterização da área. A erosão do solo foi especificamente investigada através da aplicação da Equação Universal de Perdas de solo - EUPS. O autor concluiu que são as sub-bacias dos Córregos do Monjolinho e São José, as que apresentam os maiores níveis de degradação ambiental, devido à extração mineral nas áreas próximas às nascentes.

RIOS (1993) realizou um estudo das variáveis físicas, químicas e biológicas (fitoplâncton e zooplâncton), com amostragens mensais no período de um ano (nov/90 a out/91), em dez pontos distribuídos nos principais córregos e ribeirões formadores da bacia do Ribeirão do Feijão. De acordo com os resultados e da análise estatística aplicada (ACP) o autor classificou, segundo o grau de trofia, os pontos 
de coleta e concluiu que a região mais comprometida da bacia era a que fica logo após o lixão de São Carlos, apresentando características estróficas.

TEIXEIRA (1993) caracterizou em relação às variáveis físicas, químicas e comunidade bentônica, durante um período de 6 meses, os sistemas lóticos da bacia do Ribeirão do Feijão. Foram considerados 10 pontos de coleta: 4 no Ribeirão do Feijão, 2 no Córrego Laranja Azeda, 3 no Córrego São José e 1 no Córrego do Monjolinho (Set/91 a Fev/92). Os resultados demonstraram a ocorrência de uma forte entrada de despejos (nitrogênio total de $9.139 \mu \mathrm{gL}^{-1}$ e fósforo total de $690 \mu \mathrm{gL}^{-1}$ ), provenientes da lavagem de currais e do lixão. O autor, entretanto, mostrou a capacidade de autodepuração do rio, o que permite uma água de boa qualidade (nitrogênio total de $397 \mu \mathrm{gL}^{-1}$ e fósforo total de $35 \mu \mathrm{gL}^{-1}$ ) no local de captação de água para a cidade de São Carlos.

FISCHER (1995) ao longo do período de um ano, efetuou o levantamento de dados quantitativos e qualitativos de água em sete pontos da bacia hidrográfica do Ribeirão do Feijão, num trecho de 20km (Ribeirão do Feijão e Córrego do Laranja-Azeda). Dos resultados obtidos o autor concluiu que apesar de ser o lixão a principal fonte de poluição das águas da bacia, a qualidade da água do Ribeirão do Feijão parece não ser afetada, apresentando, na maioria dos pontos monitorados, uma qualidade boa, atendendo à legislação ambiental vigente quanto à classificação e utilização de suas águas.

GUERESCHI (1995) realizou uma monitoração biológica da bacia hidrográfica do Rio Monjolinho pelo uso de invertebrados bentônicos, realizando coletas na estação seca e chuvosa. Entre as conclusões apresentadas, o autor concluiu que ocorre uma variação marcante das variáveis físicas e químicas do Rio Monjolinho, resultante principalmente da ação antrópica. A nascente apresenta uma diversidade de espécies significativa $\left(\mathrm{H}^{\prime}>2,5\right)$ e a presença de alguns organismos indicadores de boa qualidade da água, como 
Ephemeroptera. As demais estações de coleta apresentaram diversidade de espécies de moderada a baixa $\left(\mathrm{H}^{\prime}<1,5\right)$, estando presentes, em altas densidades, formas facultativas e tolerantes à poluição, como Chironomus e Oligochaeta.

SALAMI (1996) avaliou as influências climáticas e antropogênicas nas características físicas e químicas no Rio Monjolinho no inverno de 1991 e verão de 1992, concluindo que as condições do rio apresentam e definem um ecossistema extremamente variável no espaço e no tempo, principalmente no que diz respeito aos parâmetros de oxigênio dissolvido, $\mathrm{DBO}_{5}, \mathrm{DQO}$ e sólidos suspensos, que sofrem grandes influências climáticas. Processo este que se agrava no período de inverno por ser estação de estiagem, devido à falta de aporte de água.

CARVALHO (1996) avaliou a qualidade da água na porção final $(2,3 \mathrm{~km})$ do Ribeirão do Feijão, detectando produtos organoclorados como $\mathrm{HCH}\left(<0,001 \mu g L^{-1}\right)$, Heptacloro $\left(0,008 \mu \mathrm{gL}^{-1}\right)$ e DDT $\left(0,006 \mu \mathrm{gL}^{-1}\right)$, sendo este último composto acima dos valores recomendados pela Legislação Brasileira (CONAMA 20/86).

SILVA (1998) através de análises de alguns fatores abióticos, do uso e ocupação da bacia, além de análises estatísticas utilizando a Análise dos Componentes Principais, avaliou as condições da qualidade da água do Ribeirão do Feijão. O estudo compreendeu coletas e análises em dois períodos hidrológicos: seca (agosto/96) e chuva (fevereiro-março/97). Em cada período foram realizadas 11 coletas em dias diferentes em 7 estações, sendo que uma delas (est. 7) está situada no Ribeirão Laranja Azeda. Observando-se as condições ambientais distintas entre os dois períodos amostrados, a água de Ribeirão do Feijão apresentou pH ligeiramente ácido (5,7 a $6,3)$, baixa condutividade elétrica $\left(7,18 \mu \mathrm{Scm}^{-1}\right.$ a $\left.27,2 \mu \mathrm{Scm}^{-1}\right)$ e teores de nutrientes dentro dos padrões esperados para rios oligotróficos (com valores máximos para nitrogênio total de $363 \mu \mathrm{gL}^{-1}$ e para fósforo 
total de $\left.48 \mu \mathrm{gL}^{-1}\right)$. Os resultados obtidos neste estudo demonstraram que o Ribeirão do Feijão, apesar de uma série de fatores desfavoráveis (como o uso e ocupação desordenada de sua bacia e o desmatamento, dentre outras) ainda possui uma água de boa qualidade para os diversos usos.

MENDES (1998) avaliou os impactos sobre a comunidade macrozoobentônica no rio Monjolinho, dividindo-o em três trechos distintos: o primeiro, rural, próximo a nascente, com pouca influência antrópica; o segundo, urbanizado, que recebe vários tipos de efluentes provenientes da cidade de São Carlos e o terceiro, a foz, com características rurais, que recebe lançamentos oriundos das atividades agropastoris. Dentre as suas conclusões ressalta-se que a cidade é a principal fonte de impacto, mostrando uma relativa capacidade de autorecuperação em direção a foz, observada nos parâmetros físicos e químicos. Já a comunidade macrozoobentônica demonstrou que o impacto existente é constante, ampliando-se ao longo do rio, e reforçando que apesar da qualidade física e química da água mostrar sinais de recuperação, o sedimento é o compartimento final de grande parte dos contaminantes aí depositados.

BARRETO (1999), estudando a distribuição de metais no Rio do Monjolinho, observou que os únicos metais presentes em todas as coletas foram ferro, manganês e zinco. O zinco foi detectado em todas as coletas, provavelmente devido à presença de queimadas em plantações de cana-de-açúcar, muito comuns na região. Quanto ao ferro e manganês, estes estão associados ao tipo de solo da região.

Como se pode observar pelos trabalhos mencionados anteriormente, os estudos na bacia do Alto Jacaré-Guaçu têm sido conduzidos de forma isolada, verificando-se pouca integração das informações obtidas em cada sub-bacia, o que se pretende desenvolver neste trabalho. Para tanto, procurar-se-á conhecer o estado atual da qualidade da água, com vista a contribuir com medidas de recuperação e manejo. 


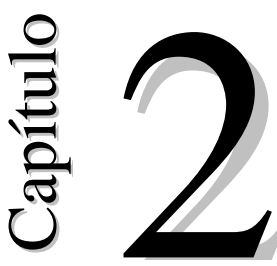

ÁREA DE ESTUDO E INFORMAÇÕES

COMPLEMENTARES

\section{1 ÁREA DE ESTUDO}

O estudo foi realizado na parte superior da bacia do Rio JacaréGuaçu, importante afluente da margem direita do rio Tietê, localizado na região Centro-oriental do Estado de São Paulo, com uma extensão aproximada de $1.100 \mathrm{Km}^{2}$, definida pelas seguintes coordenadas geográficas: $21^{\circ} 57^{\prime} 30^{\prime \prime}$ e $22^{\circ} 22^{\prime} 30^{\prime \prime}$ de latitude sul e $47^{\circ} 42^{\prime} 30^{\prime \prime}$ e $48^{\circ} 05^{\prime} 30^{\prime \prime}$ de longitude oeste. A bacia do Alto Jacaré-Guaçu limitase ao norte e nordeste com a bacia do Rio Mogi-Guaçu, ao sul e oeste com as bacias do Rio Jacaré-Pepira e do médio Jacaré-Guaçu e a leste e sudeste com a bacia do Rio Corumbataí. A área abrange, parcialmente, os municípios de Analândia, Brotas, Ibaté, Itirapina e São Carlos (Figura 1).

O Rio Jacaré-Guaçu é formado pela junção do Ribeirão do Feijão (principal fonte de abastecimento de água da cidade de São Carlos) que nasce no alto da Serra do Cuscuzeiro e o Ribeirão do Lobo (principal formador da represa do Lobo-Broa), que tem suas nascentes na Serra de Itaqueri. Tanto o Ribeirão do Feijão como o Ribeirão do Lobo estão localizados na Área de Proteção Ambiental (APA) de Corumbataí. O principal uso da terra é para pastagens, com técnicas de criação de gado bovino semi-intensiva e extensiva. Na agricultura se destacam as culturas de café, cana-de-açúcar, citrus e milho), com predomínio de pequenos e médios agricultores. Ocorrem também algumas áreas de reflorestamento (Pinus e Eucaliptus) e áreas cobertas por vegetação natural (campo e cerrado) TEIXEIRA (1993).

Após formado, o Rio Jacaré-Guaçu tem como principal afluente, na parte alta, o Rio do Monjolinho, o qual atravessa a 
cidade de São Carlos (SP), no sentido nordeste-sudoeste. O Rio Monjolinho tem como característica marcante o desenvolvimento urbano da cidade de São Carlos e, conseqüentemente, os impactos decorrentes dessas atividades, como por exemplo, o lançamento in natura de esgotos domésticos, industriais e agropastoris.
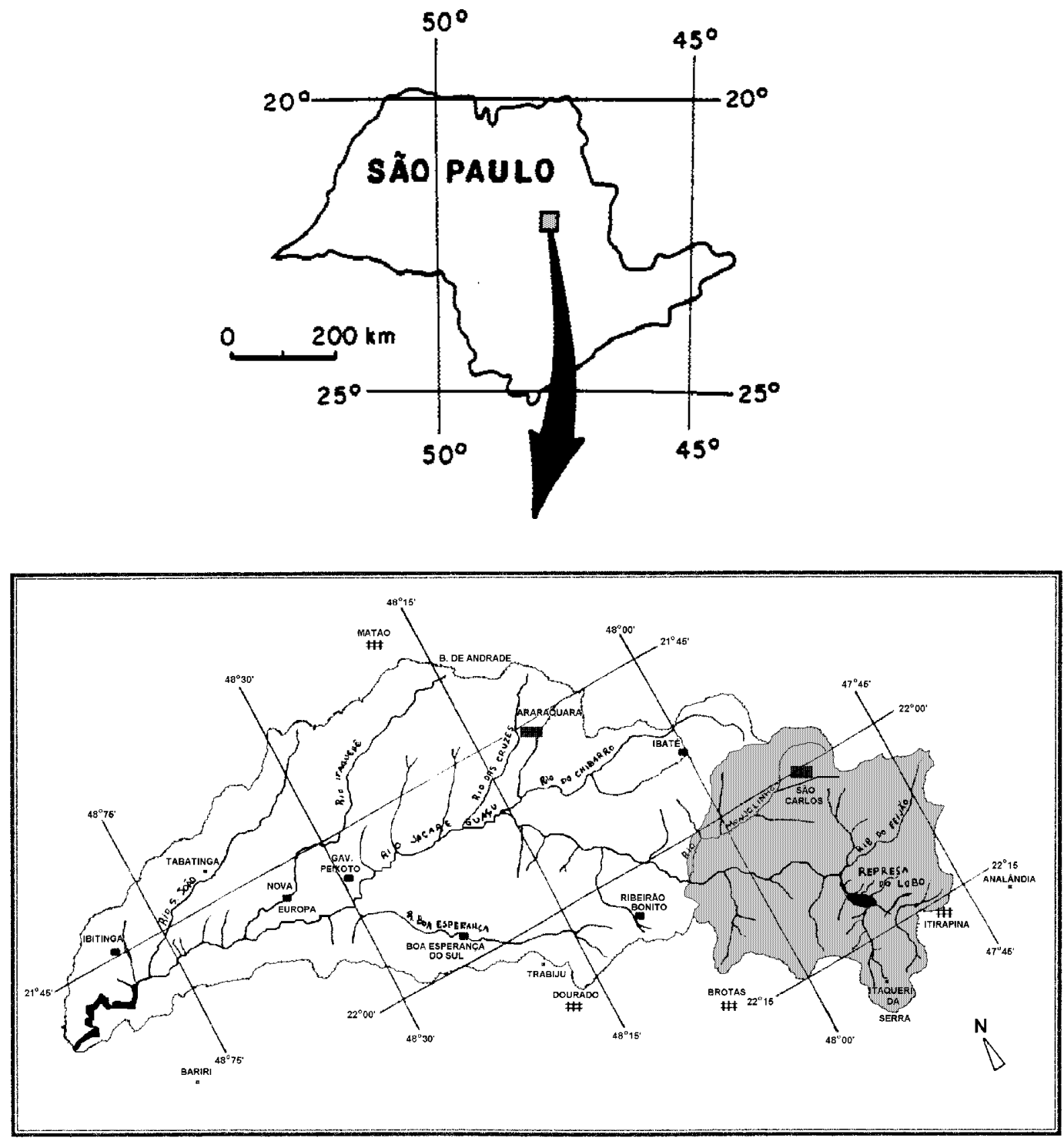

Figura 1. Localização da bacia hidrográfica do Rio Jacaré-Guaçu. 


\subsection{PRECIPITAÇÃO E TEMPERATURA DO AR}

O clima da região classifica-se como Cwb, segundo sistemática de KOPPEN, com duas estações bem definidas: a chuvosa, no verão (de outubro a março) e a seca, no inverno (de abril a setembro). A temperatura do ar acompanha as variações das duas estações gradativamente, com temperaturas mais elevadas no verão e valores mais baixos no inverno.

Na Figura 2 estão indicadas as medias mensais da precipitação pluviométrica e temperatura do ar na da bacia do Alto Jacaré-Guaçu, no período de agosto/98 a agosto/99.

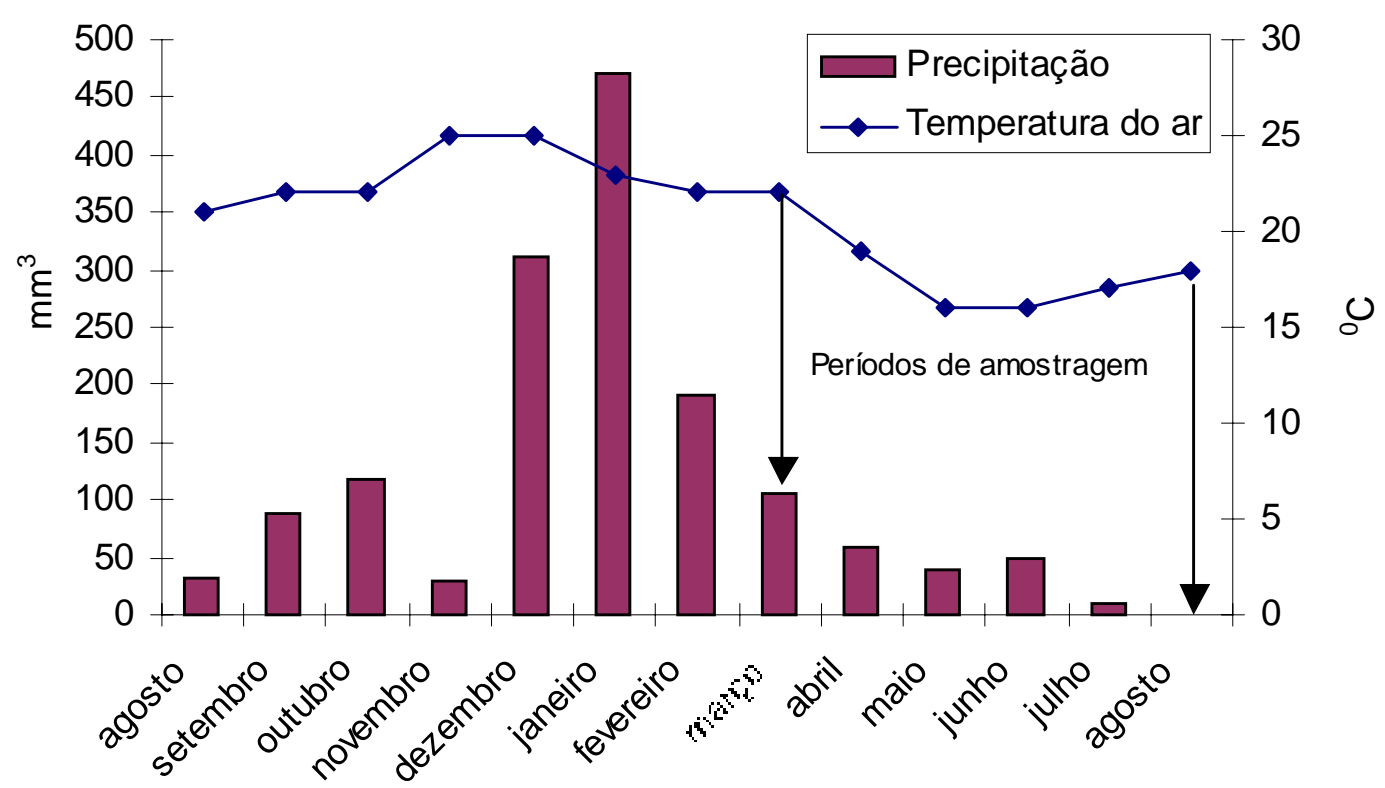

Figura 2. Medias mensais da precipitação pluviométrica e temperatura do ar na bacia do Alto Jacaré-Guaçu, no período de agosto/98 a agosto/99. 


\subsection{USO DO SOLO}

Segundo FERRANTE (1989), a vegetação primitiva da bacia era representada principalmente pelo cerrado. Entretanto, este panorama foi se modificando devido à interferência do homem, pela ocupação do solo para as diversas finalidades. Em conseqüência disso, hoje se verifica, na bacia, uma grande alteração na paisagem nesse sentido, onde somente são encontrados poucos testemunhos da vegetação original, principalmente de matas que persistem por ocupar partes mais elevadas topograficamente e de difícil ocupação.

Segundo a carta sobre o uso do solo elaborada pelo autor podem ser definidos 4 grandes tipos de ocupação:

a) Vegetação: mata densa, cerrado e campo.

b) Uso agrícola: culturas e reflorestamento.

c) Ocupação: área urbana e corpos de água.

d) Solos: hidromórficos, orgânicos, expostos e aluvião.

A partir da imagem de satélite Landsat 5 de 20/07/98 (Figura 3) podem ser observados os grandes grupos de uso e ocupação do solo e os pontos de coleta (vermelho). 


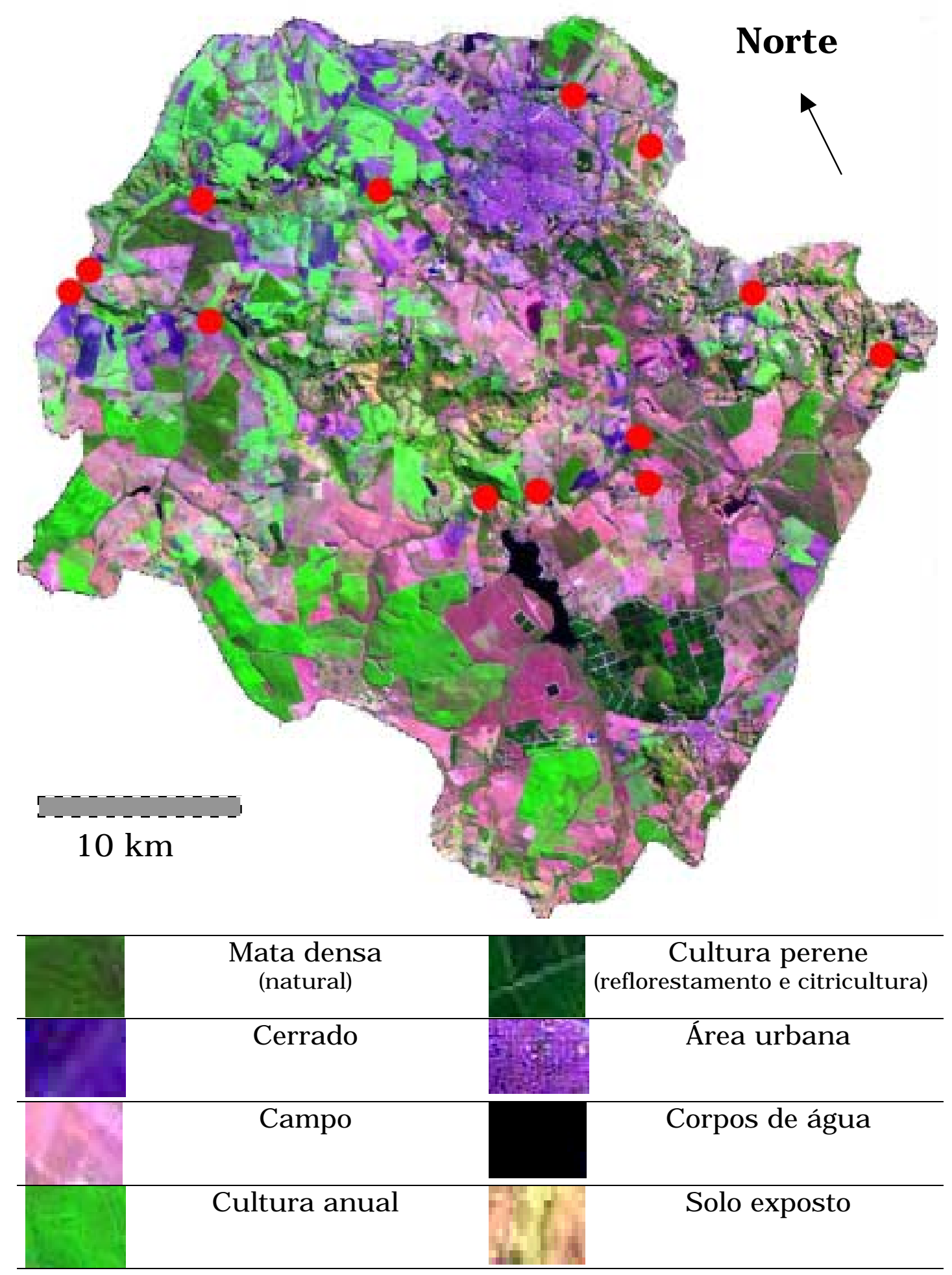

Figura 3. Imagem de satélite da bacia hidrográfica do Alto JacaréGuaçu, indicando, em vermelho, os pontos de amostragem. 


\subsection{PERÍODO E PONTOS DE AMOSTRAGEM.}

Foram efetuadas duas campanhas de amostragem: março de 1999- final do período chuvoso, e agosto de 1999- período de estiagem, de forma a abranger duas épocas extremas: chuva (verão) e estiagem (inverno). Nas coletas de verão, as amostragens foram realizadas em 8 pontos, e no inverno foram acrescidos mais 6 pontos, totalizando 14 (13 na bacia hidrográfica e um a jusante desta). O acréscimo desses 6 pontos foi feito com a finalidade de conhecer o grau de influência da cidade de São Carlos sobre o Rio do Monjolinho e posterior poder de recuperação do mesmo (pontos M3 e M4) e os pontos sobre o Jacaré-Guaçu (J1, J2, J3 e J4) foram acrescidos porque não existem, até o momento, trabalhos deste tipo na área do Jacaré-Guaçu, sendo possível, assim, quantificar o impacto do Rio do Monjolinho sobre o Rio Jacaré-Guaçu.

Paralelamente, com o intuito de visualizar espacialmente os resultados e desta forma identificar as áreas com maior ou menor grau de impacto, foi elaborado um mapa com as sub-bacias correspondentes às áreas cuja água drena para cada um dos 13 pontos de coleta. Esses pontos de coleta foram selecionados baseados em estudos anteriores realizados nessas bacias (SÉ, 1992; TEIXEIRA, 1993). A elaboração dos mapas foi feita utilizando mesa digitalizadora Summagraphics Summagrid IV, formato A1, e os software CARTALINX e IDRISI 2.0 for WINDOWS (Figura 4).

As características dos pontos de amostragem, como localização, uso do solo, latitude, longitude, altitude e área de drenagem estão apresentadas na Tabela I. 


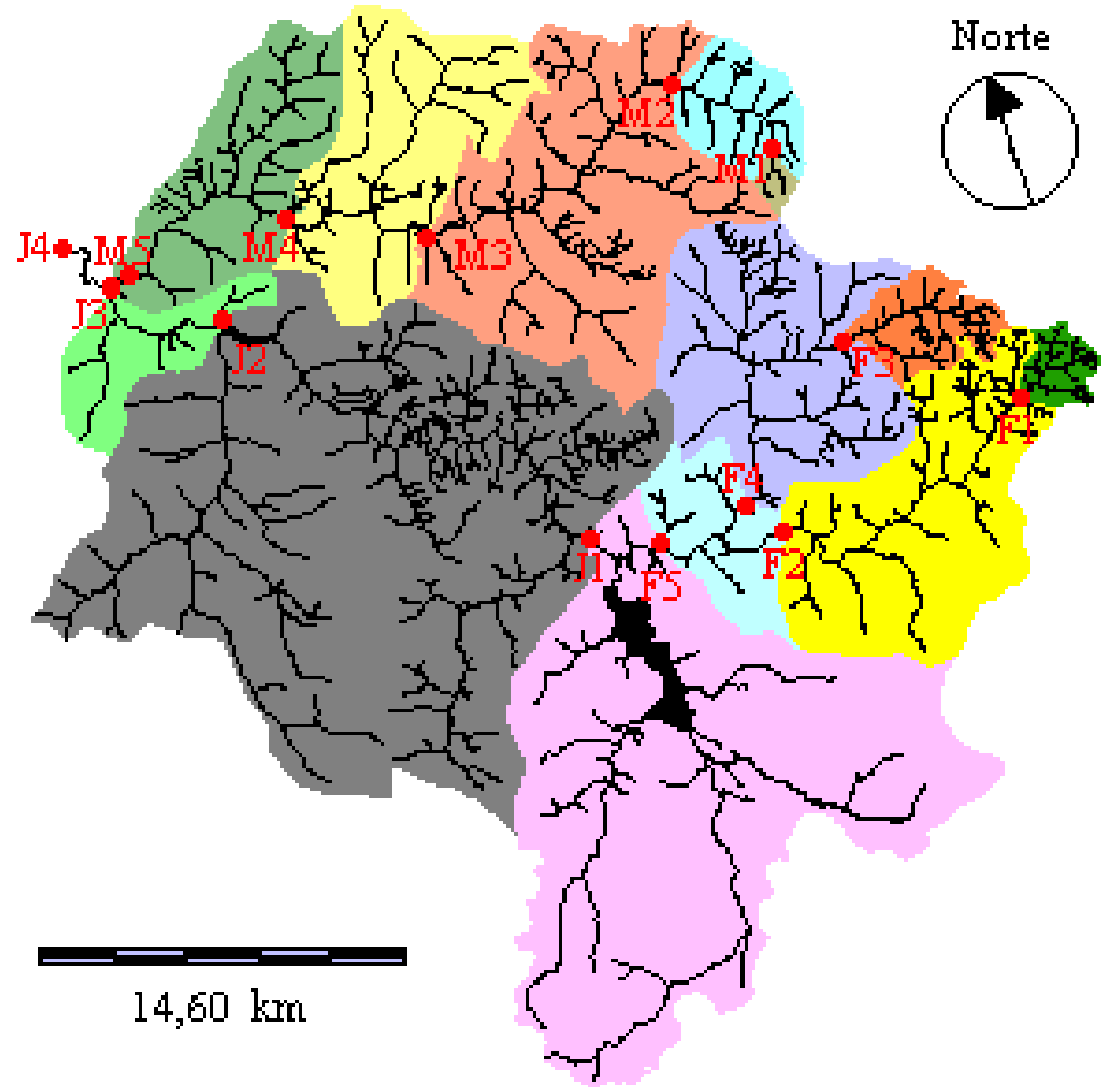

Figura 4. Rede hidrográfica da bacia do alto Jacaré-Guaçu indicando os pontos de amostragem e suas respectivas áreas de drenagem. 
TABELA I. Características dos pontos de amostragem, do presente trabalho, no Alto Jacaré-Guaçu.

\begin{tabular}{|c|c|}
\hline $\begin{array}{c}\text { Ponto de } \\
\text { amostragem }\end{array}$ & CARACTERÍSTICAS \\
\hline \multirow[t]{4}{*}{ M1 } & $\begin{array}{l}\text { Rio do Monjolinho, aproximadamente a } 2,5 \mathrm{~km} \text { da nascente, após } \\
\text { uma mata ciliar. }\end{array}$ \\
\hline & Uso do solo: pastagem. \\
\hline & Latitude: $22^{\circ} 00^{\prime} 55^{\prime \prime} \mathrm{S}$; Longitude $47^{\circ} 50^{\prime} 22^{\prime \prime} \mathrm{O}$; Altitude $880 \mathrm{~m}$. \\
\hline & Área de drenagem: aproximadamente $2.6 \mathrm{~km}^{2}$ \\
\hline \multirow[t]{4}{*}{ M2 } & $\begin{array}{l}\text { Rio do Monjolinho, a montante do local de captação de água pelo } \\
\text { Serviço Autônomo de Água e Esgoto de São Carlos (SAAE). }\end{array}$ \\
\hline & Uso do solo: pastagem. \\
\hline & Latitude: $21^{\circ}$ 59' 30" S; Longitude $47^{\circ} 52^{\prime} 60^{\prime \prime}$ O; Altitude 840 m. \\
\hline & Área de drenagem: aproximadamente $20.9 \mathrm{~km}^{2}$ \\
\hline \multirow[t]{4}{*}{ M3 } & $\begin{array}{l}\text { Rio do Monjolinho, na ponte, após a entrada do Córrego da água } \\
\text { Fria, após o matadouro municipal. }\end{array}$ \\
\hline & Uso do solo: área urbana e cultura de cana-de-açúcar. \\
\hline & Latitude: $22^{\circ} 02^{\prime} 55^{\prime \prime} \mathrm{S}$; Longitude $47^{\circ} 58^{\prime} 45^{\prime \prime} \mathrm{O}$; Altitude $700 \mathrm{~m}$. \\
\hline & Área de drenagem: aproximadamente $121.5 \mathrm{~km}^{2}$ \\
\hline \multirow[t]{4}{*}{ M4 } & $\begin{array}{l}\text { Rio do Monjolinho, sobre a ponte da estrada que vai para a Usina } \\
\text { da Serra. }\end{array}$ \\
\hline & Uso do solo: cultura de cana-de-açúcar. \\
\hline & Latitude: $22^{\circ} 02^{\prime} 10^{\prime \prime} \mathrm{S}$; Longitude $48^{\circ} 01^{\prime} 10^{\prime \prime} \mathrm{O}$; Altitude $600 \mathrm{~m}$. \\
\hline & Área de drenagem: aproximadamente $72.1 \mathrm{~km}^{2}$ \\
\hline \multirow[t]{4}{*}{ M5 } & $\begin{array}{l}\text { Rio do Monjolinho, antes da confluência com o Rio Jacaré-Guaçu } \\
\text { (aproximadamente } 20 \mathrm{~m} \text { ). }\end{array}$ \\
\hline & Uso do solo: pastagem. \\
\hline & Latitude: $22^{\circ} 03^{\prime} 45^{\prime \prime} \mathrm{S}$; Longitude $48^{\circ} 05^{\prime} 55^{\prime \prime} \mathrm{O}$; Altitude $560 \mathrm{~m}$. \\
\hline & Área de drenagem: aproximadamente $58.1 \mathrm{~km}^{2}$ \\
\hline \multirow[t]{4}{*}{$\mathrm{F} 1$} & $\begin{array}{l}\text { Ribeirão do Feijão, na ponte sobre a estrada, aproximadamente a } \\
3,5 \mathrm{~km} \text { das nascentes. }\end{array}$ \\
\hline & Uso do solo: pastagem. \\
\hline & Latitude: $22^{\circ} 06^{\prime} 16^{\prime \prime} \mathrm{S}$; Longitude $47^{\circ} 44^{\prime} 62^{\prime \prime} \mathrm{O}$; Altitude $800 \mathrm{~m}$. \\
\hline & Área de drenagem: aproximadamente $6.9 \mathrm{~km}^{2}$ \\
\hline \multirow[t]{4}{*}{ F2 } & $\begin{array}{l}\text { Ribeirão do Feijão, dentro da Fazenda Yolanda, a montante da casa } \\
\text { principal. }\end{array}$ \\
\hline & Uso do solo: pastagem e culturas temporárias. \\
\hline & Latitude: $22^{\circ} 09^{\prime} 00^{\prime \prime} \mathrm{S}$; Longitude $47^{\circ} 50^{\prime} 10^{\prime \prime} \mathrm{O}$; Altitude $700 \mathrm{~m}$. \\
\hline & Área de drenagem: aproximadamente $89.1 \mathrm{~km}^{2}$ \\
\hline
\end{tabular}


F3 Córrego do São José (formador do Córrego do Laranja Azeda, afluente do Ribeirão do Feijão), na estrada, sobre a ponte, a montante do antigo lixão de São Carlos.

Nas margens há abundante mata ciliar, com assentamento humano a aproximadamente $300 \mathrm{~m}$ à montante do ponto de coleta.

Latitude: $22^{\circ}$ 04' 79" S; Longitude $47^{\circ} 48^{\prime} 62$ ” O; Altitude 800 m.

Área de drenagem: aproximadamente $18.2 \mathrm{~km}^{2}$

F4 Córrego do Laranja Azeda, na Fazenda Yolanda, na estrada, sobre a ponte, que vai à casa principal.

Uso do solo: pastagem e culturas temporárias.

Latitude: $22^{\circ} 08^{\prime} 10^{\prime \prime} \mathrm{S}$; Longitude $47^{\circ}$ 50' 70” O; Altitude $700 \mathrm{~m}$.

Área de drenagem: aproximadamente $84.7 \mathrm{~km}^{2}$

F5 Ribeirão do Feijão, a montante da captação do SAAE.

Uso do solo: pastagem.

Latitude: $22^{\circ} 09^{\prime} 25^{\prime \prime}$ S; Longitude $47^{\circ} 52^{\prime} 80^{\prime \prime} \mathrm{O}$; Altitude $680 \mathrm{~m}$.

Área de drenagem: aproximadamente $28.1 \mathrm{~km}^{2}$

J1 Rio Jacaré-Guaçu, após a confluência dos Ribeirões do Feijão e Lobo, antes do encontro com o Ribeirão da Onça.

Uso do solo: pastagem.

Latitude: $22^{\circ}$ 09' 00” S; Longitude $47^{\circ}$ 54' 90” O; Altitude 640 m.

Área de drenagem: aproximadamente $242.9 \mathrm{~km}^{2}$

J2 Rio Jacaré-Guaçu, após a ponte a jusante da Represa de Santa Ana.

Uso do solo: pastagem, culturas temporárias e cana-de-açúcar.

Latitude: $22^{\circ} 04^{\prime} 20^{\prime \prime}$ S; Longitude $48^{\circ} 02^{\prime} 70^{\prime \prime}$ O; Altitude 620 m.

Área de drenagem: aproximadamente $322.4 \mathrm{~km}^{2}$

J3 Rio Jacaré-Guaçu, antes a confluência com o Rio do Monjolinho (aproximadamente $20 \mathrm{~m}$ ).

Uso do solo: pastagem.

Latitude: $22^{\circ} 03^{\prime} 45^{\prime \prime} \mathrm{S}$; Longitude $48^{\circ}$ 05’ 55” O; Altitude $560 \mathrm{~m}$.

Área de drenagem: aproximadamente $26.5 \mathrm{~km}^{2}$

J4 Rio Jacaré-Guaçu, aproximadamente $500 \mathrm{~m}$ após da confluência com o Rio do Monjolinho.

Uso do solo: pastagem.

Latitude: $22^{\circ} 03^{\prime}$ 00” S; Longitude $48^{\circ} 06^{\prime} 00^{\prime \prime}$ O; Altitude 520 m. 


\subsection{TEOR DE MATÉRIA ORGÂNICA E GRANULOMETRIA DO SEDIMENTO}

O teor de matéria orgânica do sedimento é resultado, geralmente, do aporte de material alóctone das áreas marginais, ação antrópica (despejos de efluentes) e processos autóctones (sedimentação e decomposição de detritos orgânicos). Trata-se de uma variável de extrema importância para os organismos bentônicos, pois pode determinar a diversidade biótica do meio. A matéria orgânica pode, também, influenciar na biodisponibilidade de metais e substâncias organocloradas no sedimento, devido à sua capacidade complexante, que age diminuindo a toxicidade destas substâncias. Outro fator importante que pode influenciar a distribuição dos organismos bentônicos e a biodisponibilidade dos tóxicos na água, é o tamanho das partículas minerais do sedimento (granulometria).

As análises da matéria orgânica e granulometria do sedimento, foram realizadas de acordo com metodologia desenvolvida pela EMBRAPA e modificada pelo Laboratório de Paleoecologia do Departamento de Ecologia e Biologia Evolutiva da Universidade Federal de São Carlos.

Na Tabela II estão indicados os valores de matéria orgânica, em porcentagem, do sedimento dos pontos de amostragem, nos dois períodos estudados, na bacia do Alto Jacaré-Guaçu. 
Tabela II. Porcentagem (\%) de matéria orgânica do sedimento nos pontos de amostragem, nos dois períodos estudados, na bacia do Alto Jacaré-Guaçu.

\begin{tabular}{ccc}
\hline $\begin{array}{c}\text { Pontos de } \\
\text { amostragem }\end{array}$ & $\begin{array}{c}\text { Período das } \\
\text { chuvas }\end{array}$ & $\begin{array}{c}\text { Período de } \\
\text { estiagem }\end{array}$ \\
\hline M1 & 1,84 & 0,62 \\
M2 & 4,49 & 0,50 \\
M3 & $*$ & 0,23 \\
M4 & $*$ & 0,43 \\
M5 & 0,19 & 0,25 \\
F1 & 0,38 & 0,41 \\
F2 & 0,10 & 0,94 \\
F3 & 1,42 & 0,55 \\
F4 & 3,47 & 0,50 \\
F5 & 6,98 & 2,57 \\
J1 & $*$ & 0,14 \\
J2 & $*$ & 0,21 \\
J3 & $*$ & 0,29 \\
J4 & $*$ & 0,23 \\
\hline
\end{tabular}

* não amostrado

De acordo a classificação para sedimentos proposta por NAUMANN in ESTEVES (1988), que classifica os sedimentos com menos de $10 \%$ de matéria orgânica como sedimentos minerais e com mais de 10\% como sedimentos orgânicos, os sedimentos da bacia, nos dois períodos estudados, são de tipo mineral.

$\mathrm{Na}$ Tabela III estão indicadas as porcentagens de areia e fração fina (silte + argila) do sedimento, dos pontos de amostragem, nos dois períodos estudados, na bacia do Alto Jacaré-Guaçu. 
Tabela III. Porcentagens de areia e fração fina (silte + argila), do sedimento dos pontos de amostragem, nos dois períodos estudados, da bacia do Alto Jacaré-Guaçu.

\begin{tabular}{ccccc}
\hline Período & \multicolumn{2}{c}{ Chuvoso } & \multicolumn{2}{c}{ Estiagem } \\
\hline $\begin{array}{c}\text { Ponto de } \\
\text { amostragem }\end{array}$ & Areia & Silte + Argila & Areia & Silte + Argila \\
\hline M1 & 93,43 & 6,57 & 95,07 & 4,93 \\
M2 & 69,59 & 30,41 & 92,42 & 7,58 \\
M3 & $*$ & $*$ & 98,33 & 1,67 \\
M4 & $*$ & $*$ & 96,30 & 3,70 \\
M5 & 97,58 & 2,42 & 98,02 & 1,98 \\
F1 & 96,79 & 3,21 & 95,71 & 4,29 \\
F2 & 98,75 & 1,25 & 97,01 & 2,99 \\
F3 & 89,23 & 10,77 & 91,82 & 8,18 \\
F4 & 97,31 & 2,69 & 92,99 & 7,01 \\
F5 & 62,90 & 37,10 & 80,99 & 19,01 \\
J1 & $*$ & $*$ & 96,57 & 3,43 \\
J2 & $*$ & $*$ & 98,39 & 1,61 \\
J3 & $*$ & $*$ & 95,51 & 4,49 \\
J4 & $*$ & $*$ & 96,30 & 3,70 \\
\hline
\end{tabular}

* não amostrado

De acordo com a classificação de SHEPARD para sedimentos (SUGUIO, 1973), as amostras no período chuvoso se classificam como arenosas (mais de $75 \%$ de fração areia), exceto as amostras dos pontos de captação, M2 e F5, que correspondem à classificação de areno-argilosa com 70\% de areia e 30\% de argila. Já no período seco as amostras não tiveram variações quanto a sua classificação, sendo todas classificadas como arenosas. 


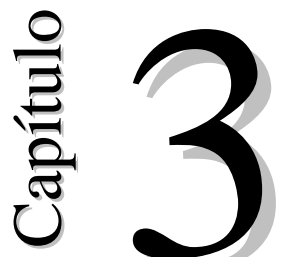

\section{CARACTERÍZAÇÃO FÍSICA E QUÍMICA DA ÁGUA DA BACIA HIDROGRÁFICA DO} ALTO JACARÉ-GUAÇU

\subsection{INTRODUÇÃO}

As características físicas e químicas de todo corpo de água são determinadas, em grande parte, pelo clima, geomorfologia e condições geoquímicas prevalecentes na bacia de drenagem. O intemperismo de rochas é, geralmente, determinante das características químicas das águas, e essas variam com a geologia e com a intensidade das entradas por outras vias, incluindo a precipitação pluviométrica e a poluição.

Segundo MEYBECK et. al. (1992) a qualidade da água em um determinado ponto de amostragem de um rio depende de muitos fatores, incluindo a proporção do escoamento superficial e água subterrânea, reações dentro do sistema rio governadas por processos internos, a mistura de águas de tributários de diferentes qualidades e da entrada de poluentes.

Os desenvolvimentos industriais, aliados à migração do homem do campo para os centros urbanos, têm gerado graves problemas para os corpos da água localizados próximos as cidades. Entre os impactos que podem ser observados destacam-se aqueles oriundos da deficiente gestão das bacias hidrográficas, como desflorestamento de áreas próximas aos corpos de água e lançamento de efluentes sem tratamento.

O conhecimento atual das características físicas e químicas da água da bacia hidrográfica do Alto Jacaré-Guaçu, sua comparação através de estudos anteriores em suas sub-bacias formadoras e a integração destas em uma só, permitirá identificar os problemas 
prioritários para o desenvolvimento de ações corretivas e de recuperação do ambiente, considerando-se seus vários usos.

O presente capítulo teve como objetivo avaliar as características físicas e químicas dos principais rios formadores da bacia do Alto Jacaré-Guaçu, em duas épocas do ano, chuva e estiagem de 1999, relacionando-a com o uso e ocupação da bacia e verificar se os valores, das variáveis analisadas, estão de acordo com os Padrões Brasileiros de Qualidade Ambiental (Resolução CONAMA 20/86), para corpos de água classe 2, a qual é a classe dos rios formadores da bacia do Alto Jacaré-Guaçu, e por último realizar uma análise temporal, através de estudos anteriores realizados nas sub-bacias do Rio do Monjolinho e Ribeirão do Feijão para conhecer, desta forma, a tendência da qualidade da água da bacia.

\subsection{MATERIAIS E MÉTODOS}

\subsubsection{Variáveis analisadas}

Foram realizadas as análises das seguintes variáveis físicas e químicas da água:

- Temperatura da água, pH e concentração de oxigênio dissolvido: determinados diretamente no campo, através de um multi-sensor (Water Quality Checker), marca HORIBA, modelo U10.

- Variáveis que indicam o balanço mineral: condutividade (HORIBA); turbidez, através de um Turbidímetro (APHA, 1989); carbono inorgânico dissolvido, através de analisador TOC 5000 Shimadzu; materiais inorgânicos em suspensão segundo a técnica descrita em APHA (1989); alcalinidade, pelo método da titulação potenciométrica (APHA, 1989); dureza, pelo método titulométrico do EDTA (APHA, 1989) e composição iónica (cálcio, magnésio, sódio, potássio, 
bicarbonato, carbonato, sulfato e cloreto) segundo APHA (1989).

- Variáveis que caracterizam a quantidade de matéria orgânica: carbono orgânico dissolvido, através de analisador TOC 5000 Shimadzu; demanda química de oxigênio (DQO), pelo método colorimétrico (APHA, 1989); demanda bioquímica de oxigênio $\left(\mathrm{DBO}_{5}\right)$ e sólidos orgânicos em suspensão, determinados segundo a técnica descrita em APHA (1989).

- Variáveis indicadoras de eutrofização: concentração de nitrogênio orgânico total, segundo método Kjeldahl (APHA, 1989); nitrito (GOLTERMAN, 1978); nitrato (MACKERETH et al. 1978); amônia (KOROLEFF, 1976) e fósforo total (APHA, 1989).

Além das análises das diferentes variáveis, foi aplicado o Índice do Estado Trófico (IET) de Carlson (1977). O IET tem por finalidade classificar os corpos da água em diferentes graus de trofia, ou seja, avaliar a qualidade da água quanto ao enriquecimento por nutrientes. TOLEDO Jr. et al. (1983) baseando-se em dados de diferentes reservatórios do Estado de São Paulo, fez alguns ajustes na fórmula original do IET de Carlson, com o intuito de caracterizar o estado trófico de reservatórios do Estado de São Paulo, utilizando as variáveis fósforo total e clorofila $a$.

Para o calculo do IET na bacia do Alto Jacaré-Guaçu (SP) foi utilizada apenas a variável fósforo total (IET $\mathrm{P}$ ). Não foi considerada a variável clorofila a pelo estudo estar sendo desenvolvido em ambientes lóticos de pequeno porte, os quais apresentam alta correnteza, turbidez e concentração de material em suspensão, o que dificultaria uma análise confiável de clorofila $a$. 
O IET para fósforo é definido como:

$$
\operatorname{IET}(\mathrm{P})=10\left(6-\frac{\ln \left(80,32 / \mathrm{P}^{*}\right)}{\ln 2} \quad \quad \quad{ }^{*} \text { unidade em } \mathrm{mgm}^{-3}\right)
$$

De acordo com os diferentes valores de IET as águas podem ser classificadas como: oligotrófica, mesotrófica, eutrófica e hipereutrófica, para as quais são dados valores de classes de IET de 1 a 4 , respectivamente (Tabela I).

Tabela I. Classificação do estado trófico segundo o índice de Carlson, modificado.

\begin{tabular}{ccc}
\hline Critério & Estado trófico & Classes do IET \\
\hline IET $\leq 44$ & Oligotrófico & 1 \\
$44<$ IET $\leq 54$ & Mesotrófico & 2 \\
$54<$ IET $\leq 74$ & Eutrófico & 3 \\
IET $>74$ & Hipereutrófico & 4 \\
\hline
\end{tabular}

\subsubsection{Análise estatística.}

Utilizou-se a Análise dos Componentes Principais (ACP) como método de ordenação, a partir das correlações entre as variáveis físicas e químicas da água para os períodos de verão e inverno, a fim de agrupar os pontos através da similaridade e da dissimilaridade apresentadas nas variáveis analisadas.

\subsection{RESULTADOS}

$\mathrm{Na}$ campanha de verão (março/99) foram coletadas amostras de água para análise de temperatura da água, $\mathrm{pH}$, concentração de oxigênio dissolvido, condutividade, turbidez, demanda bioquímica de oxigênio ( $\left.\mathrm{DBO}_{5}\right)$, material em suspensão (total, orgânico e inorgânico), carbono dissolvido (total, inorgânico e orgânico), nitrogênio orgânico 
total (Kjeldahl), amônia, nitrito, nitrato e fósforo total. Além do aumento de pontos de amostragem na campanha de inverno (agosto/99), foram acrescidos os seguintes parâmetros: alcalinidade, dureza, composição iônica (cálcio, magnésio, sódio, potássio, bicarbonato, carbonatos, sulfatos e cloretos) e demanda química de oxigênio (DQO), como apresentados nas tabelas II e III (anexo).

3.3.1 Temperatura da água, pH e concentração de oxigênio dissolvido

Durante a campanha de março o menor valor de temperatura $\left(21^{\circ} \mathrm{C}\right)$ foi registrado nos pontos $\mathrm{M} 1$ e $\mathrm{F} 1$; já o maior valor $\left(25^{\circ} \mathrm{C}\right)$ foi obtido no ponto M5. Em agosto os valores da temperatura da água estiveram entre $13^{\circ} \mathrm{C}(\mathrm{F} 1)$ e $19^{\circ} \mathrm{C}$ (M3 e M4), sendo que este aumento, de montante a jusante dos córregos, deve-se, principalmente, à hora de coleta (as coletas foram realizadas no sentido nascente-foz). Além da variação longitudinal, observou-se também uma variação temporal, ou seja, a temperatura média em março/99 foi de $23^{\circ} \mathrm{C}$ e a de agosto foi de $17^{\circ} \mathrm{C}$ (Tabela IV).

Tabela IV. Hora da medição e temperatura da água nos pontos de amostragem da bacia hidrográfica do Alto Jacaré-Guaçu.

\begin{tabular}{ccccc}
\hline $\begin{array}{c}\text { Pontos de } \\
\text { Amostragem }\end{array}$ & $\begin{array}{c}\text { Hora da } \\
\text { medição }\end{array}$ & $\begin{array}{c}\text { Verão } \\
\left({ }^{\circ} \mathrm{C}\right)\end{array}$ & $\begin{array}{c}\text { Hora da } \\
\text { medição }\end{array}$ & $\begin{array}{c}\text { Inverno } \\
\left({ }^{\circ} \mathrm{C}\right)\end{array}$ \\
\hline M1 & $8: 30$ & 20,90 & $11: 15$ & 18,10 \\
M2 & $9: 30$ & 23,90 & $11: 50$ & 18,60 \\
M3 & $*$ & $*$ & $10: 30$ & 18,60 \\
M4 & $*$ & $*$ & $10: 00$ & 17,60 \\
M5 & $11: 00$ & 24,90 & $9: 00$ & 16,80 \\
F1 & $8: 20$ & 21,40 & $9: 00$ & 13,30 \\
F2 & $9: 30$ & 23,40 & $10: 00$ & 16,00 \\
F3 & $9: 00$ & 23,30 & $10: 25$ & 15,40 \\
F4 & $10: 00$ & 23,90 & $10: 20$ & 16,40 \\
F5 & $10: 20$ & 24,30 & $10: 30$ & 16,40 \\
J1 & $*$ & $*$ & $9: 15$ & 16,80 \\
J2 & $*$ & $*$ & $8: 20$ & 17,20 \\
J3 & $*$ & $*$ & $9: 00$ & 17,60 \\
J4 & $*$ & $*$ & $9: 30$ & 17,70 \\
\hline não amostrado & & &
\end{tabular}


Com relação ao $\mathrm{pH}$ verificou-se características mais ácidas no período de verão e ligeiramente ácidas no período de inverno. No verão os valores de pH estiveram entre 4,99 (M1) e 6,64 (M5), valores, na maioria dos casos, inferiores aos estipulados pela resolução CONAMA 20, que fixa os valores de pH entre 6 e 9. Já no inverno, quando não ocorreram chuvas, os valores de $\mathrm{pH}$ evidenciaram águas ligeiramente ácidas, com variações entre 6,01 (F1) e 6,73 (F5), conforme Figura 1.

As concentrações de oxigênio dissolvido registradas no verão, não apresentaram um padrão de variação. A concentração mínima foi obtida no ponto M2 (com 5,67 $\mathrm{mgL}^{-1}$ ) e a máxima $\left(8,56 \mathrm{mgL}^{-1}\right)$ no ponto F1. Semelhante ao período chuvoso, as concentrações de oxigênio dissolvido, no período de estiagem, não apresentaram padrão definido. As concentrações variaram entre $6,20 \mathrm{mgL}^{-1}$ (no ponto M5) e 11,57 $\mathrm{mgL}^{-1}$ (no ponto F1), conforme demonstrado na Figura 2. 

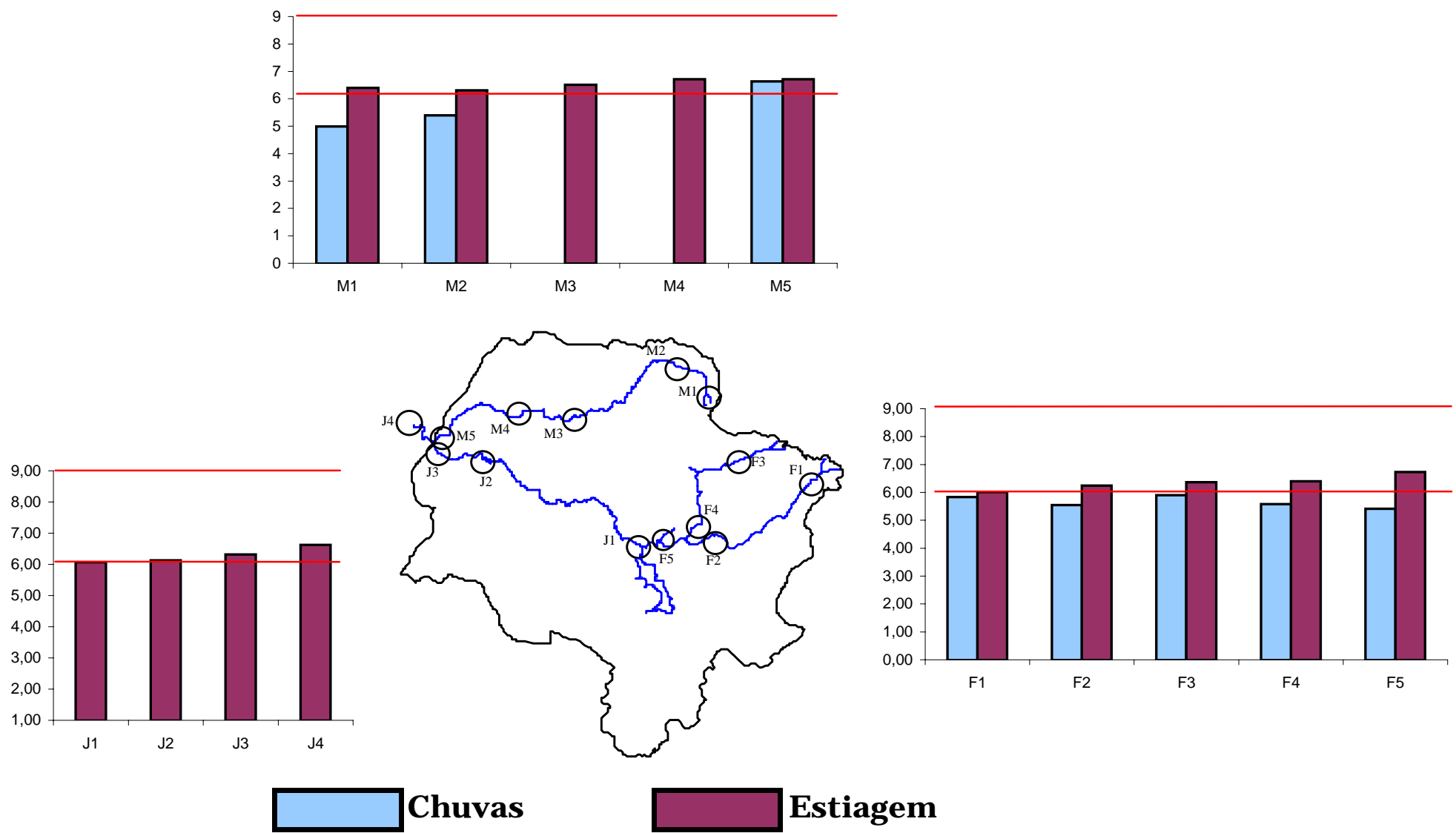

Estiagem

Faixa de Variação(6 a 9) CONAMA 20/86

Figura 1. Valores de pH da água, na bacia hidrográfica do Alto Jacaré-Guaçu, nos períodos de estudo. 

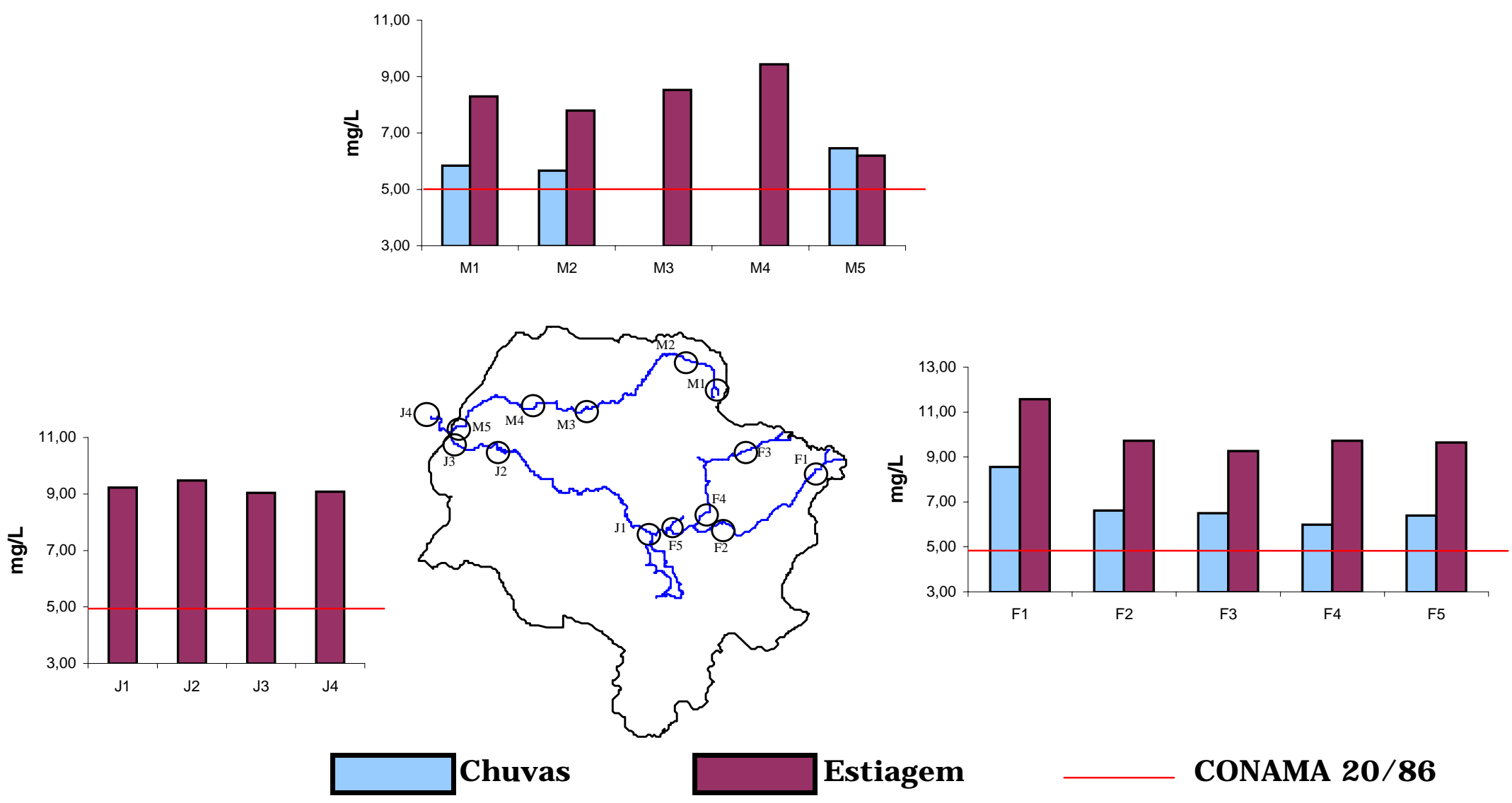

Figura 2. Concentração de oxigênio dissolvido da água, na bacia hidrográfica do Alto Jacaré-Guaçu, nos períodos de estudo. 
3.3.2 Variáveis que Indicam o balanço mineral: condutividade elétrica, turbidez, material em suspensão inorgânico, alcalinidade, dureza e ions maiores

Os valores de condutividade da água, no período de verão foram, em geral, baixos, com variações entre 11 e $33 \mu \mathrm{Scm}^{-1}$ No período de inverno, verificou-se comportamento semelhante ao período de verão, com valores de condutividade baixos (entre 6 e $27 \mu \mathrm{Scm}^{-1}$ ), com exceção novamente dos pontos localizados após a área urbana (M3, M4 e M5), com $113 \mu \mathrm{Scm}^{-1}, 119 \mu \mathrm{Scm}^{-1}$ e $133 \mu \mathrm{Scm}^{-1}$, respectivamente (Figura 3 ).

Para a turbidez foram registrados valores, no período chuvoso, entre 22 NTU (F2) e 100 NTU (M5). Este último valor é o limite máximo permitido pela Resolução CONAMA 20. No período de estiagem, verificou-se menor variação nos valores de turbidez em relação ao período chuvoso, com um valor mínimo de 3NTU no ponto F3 e um máximo de 45NTU nos pontos M3 e M4 (Tabela V).

Em março/99, nos valores de carbono inorgânico dissolvido observou-se um aumento após a área urbana, com decréscimos gradativos, tendo-se registrado valores entre $0,89 \mathrm{mgL}^{-1}$ (F2) e 5,73mgL-1 (M5) (Tabela VI). As concentrações de carbono total e inorgânico dissolvido do período de estiagem foram descartadas por problemas de calibração do equipamento. 


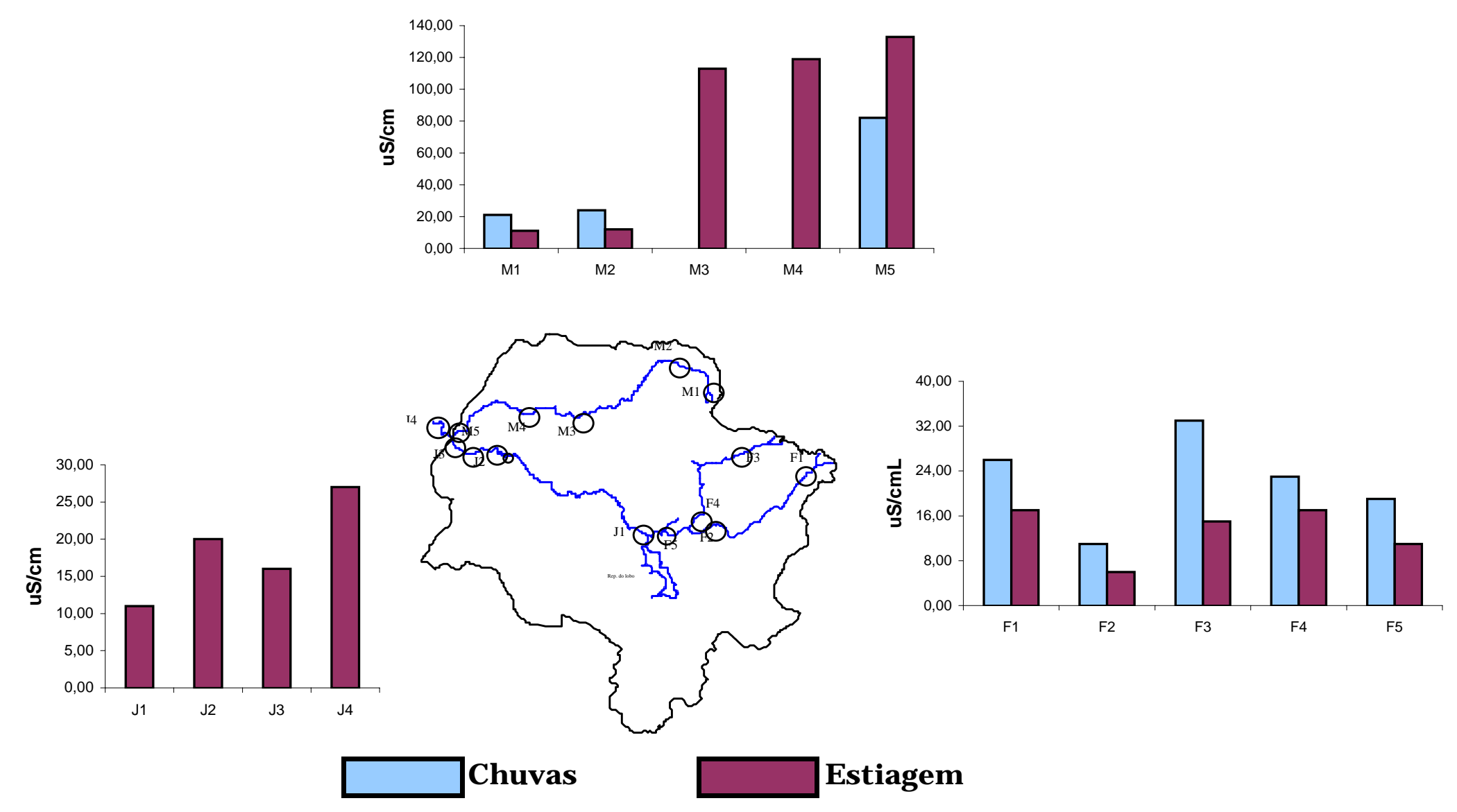

Figura 3. Valores de condutividade da água, na bacia hidrográfica do Alto Jacaré-Guaçu, nos períodos de estudo. 
Tabela V. Valores de turbidez (NTU), na bacia hidrográfica do Alto Jacaré-Guaçu, nos dois períodos amostrados.

\begin{tabular}{ccc}
\hline $\begin{array}{c}\text { Pontos de } \\
\text { Amostragem }\end{array}$ & $\begin{array}{c}\text { Período das } \\
\text { chuvas }\end{array}$ & $\begin{array}{c}\text { Período de } \\
\text { estiagem }\end{array}$ \\
\hline M1 & 62 & 4 \\
M2 & 92 & 10 \\
M3 & $*$ & 45 \\
M4 & $*$ & 45 \\
M5 & 100 & 19 \\
F1 & 26 & 5 \\
F2 & 22 & 6 \\
F3 & 24 & 3 \\
F4 & 98 & 10 \\
F5 & 58 & 11 \\
J1 & $*$ & 7 \\
J2 & $*$ & 4 \\
J3 & $*$ & 7 \\
J4 & $*$ & 8 \\
\hline * não amostrado &
\end{tabular}

Limite CONAMA 20/86: 100

Tabela VI. Concentrações de carbono total e inorgânico (mgL-1) e porcentagem do carbono inorgânico em relação ao total (\%), na bacia do Alto Jacaré-Guaçu, no período de março de 1999.

\begin{tabular}{cccc}
\hline $\begin{array}{c}\text { Pontos de } \\
\text { amostragem }\end{array}$ & $\begin{array}{c}\text { Carbono } \\
\text { Total }\end{array}$ & $\begin{array}{c}\text { Carbono } \\
\text { Inorgânico }\end{array}$ & $\begin{array}{c}\text { Porcentagem } \\
\text { (\%) }\end{array}$ \\
\hline M1 & 2,34 & 1,79 & 76,56 \\
M2 & 2,88 & 2,65 & 91,81 \\
M5 & 6,83 & 5,73 & 83,82 \\
F1 & 3,47 & 1,78 & 51,24 \\
F2 & 1,97 & 0,89 & 45,09 \\
F3 & 3,34 & 3,21 & 96,07 \\
F4 & 3,17 & 1,87 & 59,04 \\
F5 & 2,42 & 1,36 & 56,23 \\
\hline
\end{tabular}

Os valores de material em suspensão inorgânico, na época das chuvas, estiveram entre 4,38mgL-1 (F1) e 59,33mgL-1 (F4). Já na época da seca, o valor mais baixo foi obtido no ponto F3 $\left(0,40 \mathrm{mgL}^{-1}\right)$ e os valores mais altos nos pontos após a área urbana M3 (22,33mgL-1) e M4 (24,00mgL-1), conforme apresentado na Figura 4. 

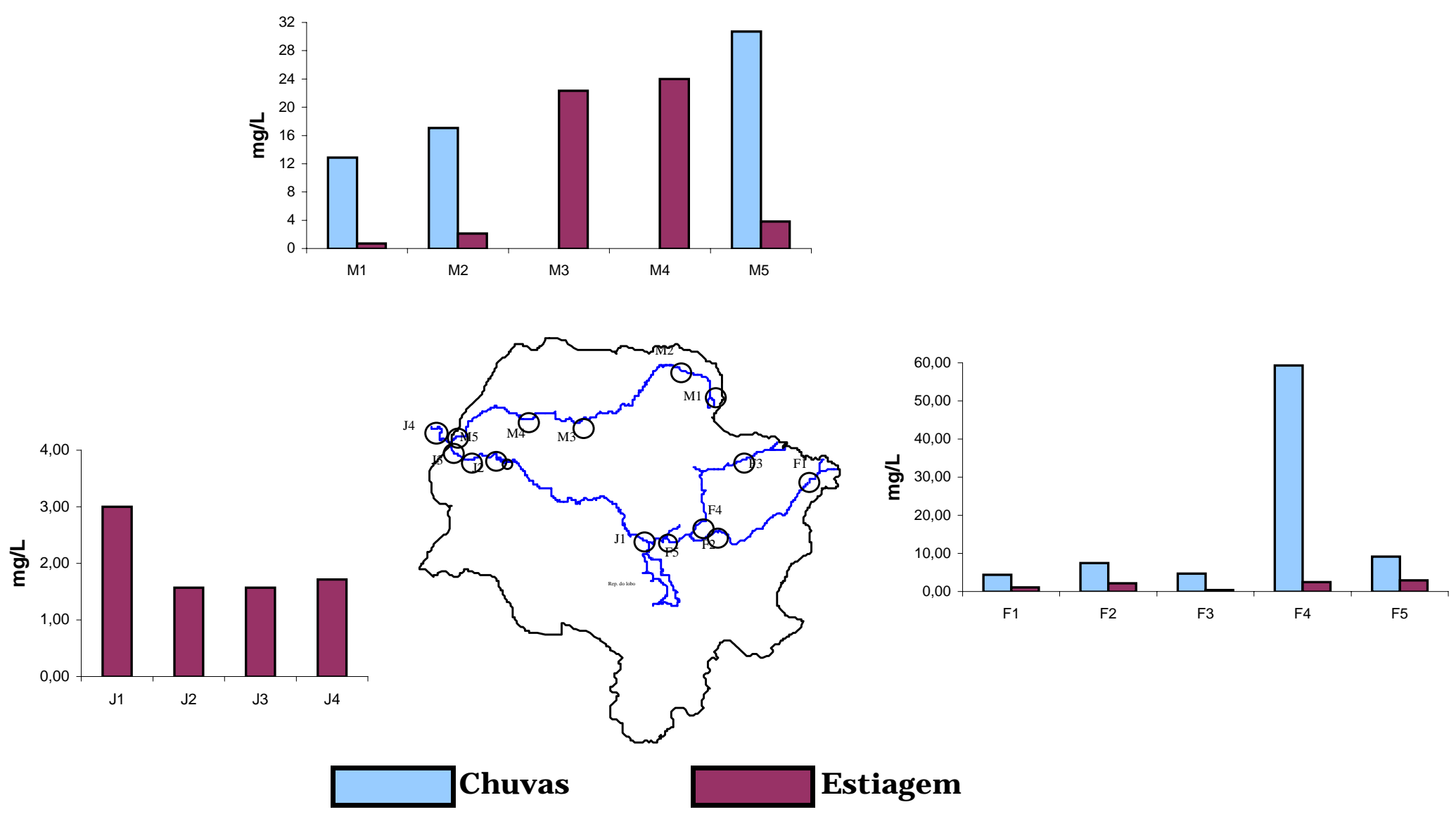

Figura 4. Valores de MSImg/L), na bacia hidrográfica do Alto Jacaré-Guaçu, nos períodos de estudo. 
Padrão semelhante ao observado para condutividade foi encontrado para alcalinidade e a dureza (analisadas só em agosto/99), com valores mínimos de $5 \mathrm{mgL}^{-1}$ (alcalinidade) e $2 \mathrm{mgL}^{-1}$ (dureza) na estação F2 e máximos de $40 \mathrm{mgL}^{-1}$, 44mgL-1 e $51 \mathrm{mgL}^{-1}$ (alcalinidade) e $28 \mathrm{mgL}^{-1}, 28 \mathrm{mgL}^{-1}$ e $30 \mathrm{mgL}^{-1}$ (dureza), nos pontos após a área urbana (M3, M4 e M5, respectivamente), conforme apresentado na Tabela VII.

Tabela VII. Valores de alcalinidade e dureza total da água, na bacia hidrográfica do Alto Jacaré-Guaçu, em agosto de 1999.

\begin{tabular}{ccc}
\hline $\begin{array}{c}\text { Pontos de } \\
\text { Amostragem }\end{array}$ & $\begin{array}{c}\text { Alcalinidade } \\
\left(\mathrm{mgL}^{-1}\right)\end{array}$ & $\begin{array}{c}\text { Dureza total } \\
\left(\mathrm{mgL}^{-1}\right)\end{array}$ \\
\hline M1 & 8 & 8 \\
M2 & 8 & 8 \\
M3 & 40 & 28 \\
M4 & 44 & 28 \\
M5 & 51 & 30 \\
F1 & 9 & 6 \\
F2 & 5 & 2 \\
F3 & 14 & 12 \\
F4 & 7 & 6 \\
F5 & 7 & 4 \\
J1 & 7 & 4 \\
J2 & 10 & 6 \\
J3 & 9 & 6 \\
J4 & 13 & 8 \\
\hline
\end{tabular}

Semelhante a alcalinidade e dureza, os íons só foram analisados em agosto/99. Para o cálcio, sódio e bicarbonato verificouse um comportamento similar a alcalinidade e a dureza, com valores máximos após a área urbana. Para potássio, além da ocorrência de valores máximos após a área urbana, também foi verificada uma alta concentração $\left(2,60 \mathrm{mgL}^{-1}\right)$ no ponto F1. Para o cloreto observou-se um padrão similar ao cálcio, sódio e bicarbonato, com as maiores concentrações após a área urbana e no ponto F3 (concentração máxima com 29,00mgL-1). Com relação aos sulfatos o comportamento 
foi semelhante à do potássio, já que para os pontos localizados no Rio Monjolinho e o ponto F1 (nascente do Ribeirão do Feijão) foram registradas concentrações de sulfatos em ordem de magnitude superior à dos outros pontos da bacia do Alto Jacaré-Guaçu. Padrão semelhante a do cloreto foi verificado para magnésio, com maiores concentrações na bacia do Monjolinho e no ponto F3, mas em geral seus valores foram baixos, estando entre $1,03 \mathrm{mgL}^{-1}$ (no ponto M5) e 0,21 $\mathrm{mgL}^{-1}$ (no ponto F2). A Resolução CONAMA 20 fixa valores das concentrações, somente para o cloreto e para o sulfato, em $250 \mathrm{mgL}^{-1}$ (Figura 5). 


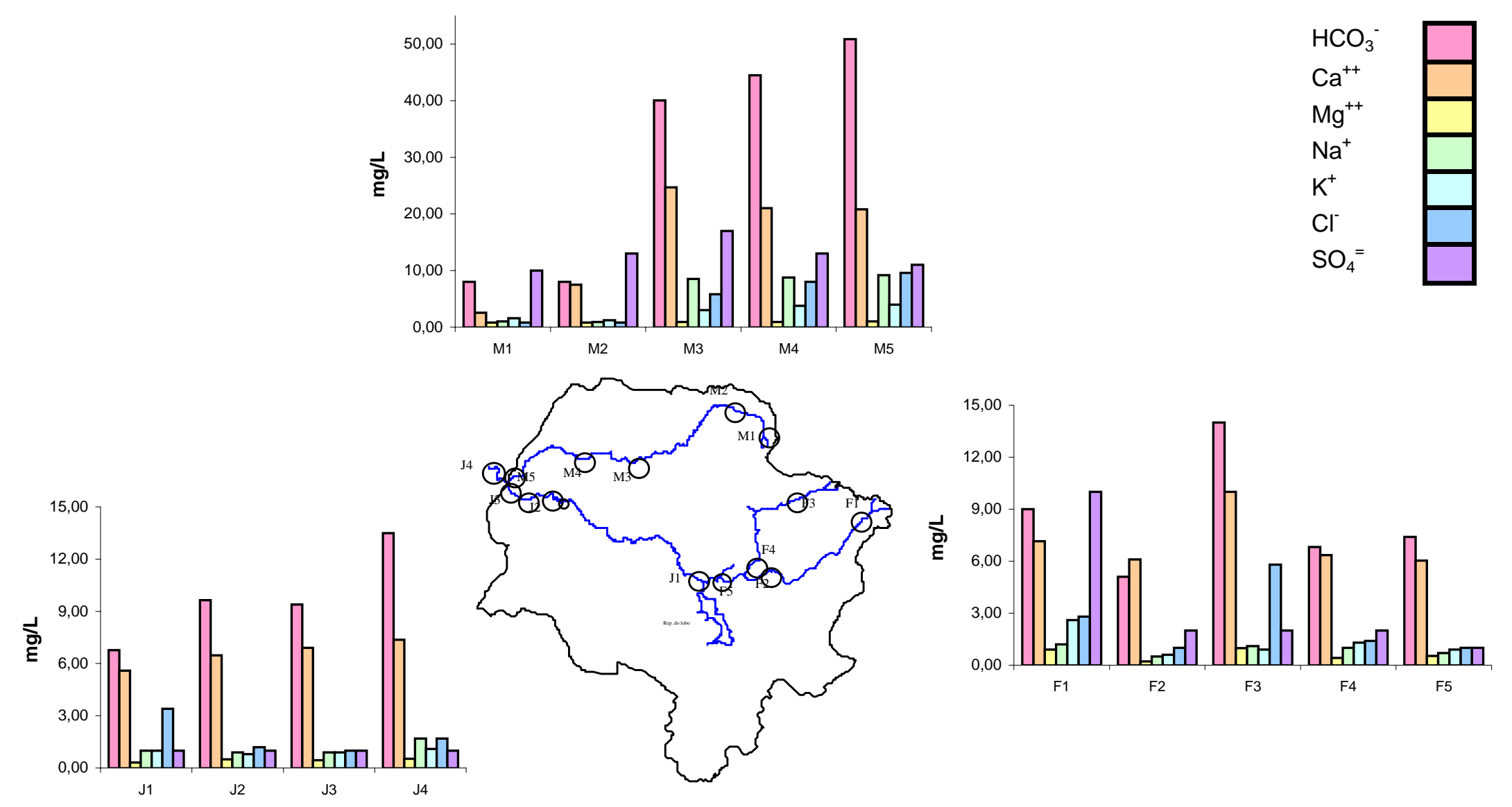

Figura 5. Valores de íons da águłmg/L), na bacia hidrográfica do Alto Jacaré-Guaçu, no período de estiagem 
3.3.3 Variáveis que caracterizam a quantidade de matéria orgânica: carbono orgânico total, material em suspensão total, demanda química de oxigênio e demanda bioquímica de oxigênio

No período chuvoso, as concentrações de carbono orgânico dissolvido variaram de $0,13 \mathrm{mgL}^{-1}$ (F3) a $1,69 \mathrm{mgL}^{-1}$ (Tabela VIII). As análises de carbono dissolvido, do período de estiagem, foram descartadas por problemas de calibração do equipamento.

Tabela VIII. Concentrações de carbono total e orgânico em (mgL-1) e porcentagem do carbono orgânico em relação ao total (\%), na bacia hidrográfica do Alto Jacaré-Guaçu, em março de 1999.

\begin{tabular}{cccc}
\hline $\begin{array}{c}\text { Pontos de } \\
\text { amostragem }\end{array}$ & $\begin{array}{c}\text { Carbono } \\
\text { Total }\end{array}$ & $\begin{array}{c}\text { Carbono } \\
\text { Orgânico }\end{array}$ & $\begin{array}{c}\text { Porcentagem } \\
(\%)\end{array}$ \\
\hline M1 & 2,34 & 0,55 & 23,44 \\
M2 & 2,884 & 0,24 & 8,19 \\
M5 & 6,83 & 1,11 & 16,18 \\
F1 & 3,47 & 1,69 & 48,76 \\
F2 & 1,97 & 1,08 & 54,91 \\
F3 & 3,34 & 0,13 & 3,93 \\
F4 & 3,17 & 1,30 & 40,96 \\
F5 & 2,42 & 1,06 & 43,77 \\
\hline
\end{tabular}

Em relação ao material em suspensão orgânico verificaram-se comportamentos semelhantes em ambos períodos estudados. No verão os valores mais baixos foram obtidos nos pontos próximos às nascentes (M1, F1 e F3), com valores de 4,70mgL-1, 2,52mgL-1 e $1,60 \mathrm{mgL}^{-1}$, respectivamente; já os mais altos ocorreram nos pontos M5 $\left(8,23 \mathrm{mgL}^{-1}\right)$ e F4 $\left(9,49 \mathrm{mgL}^{-1}\right)$. O padrão da variação do material em suspensão orgânico na estiagem foi similar a variação no período das chuvas, com os menores valores nas nascentes e os maiores após a área urbana (M3, M4 e M5) e no ponto F4 (Figura 6). 

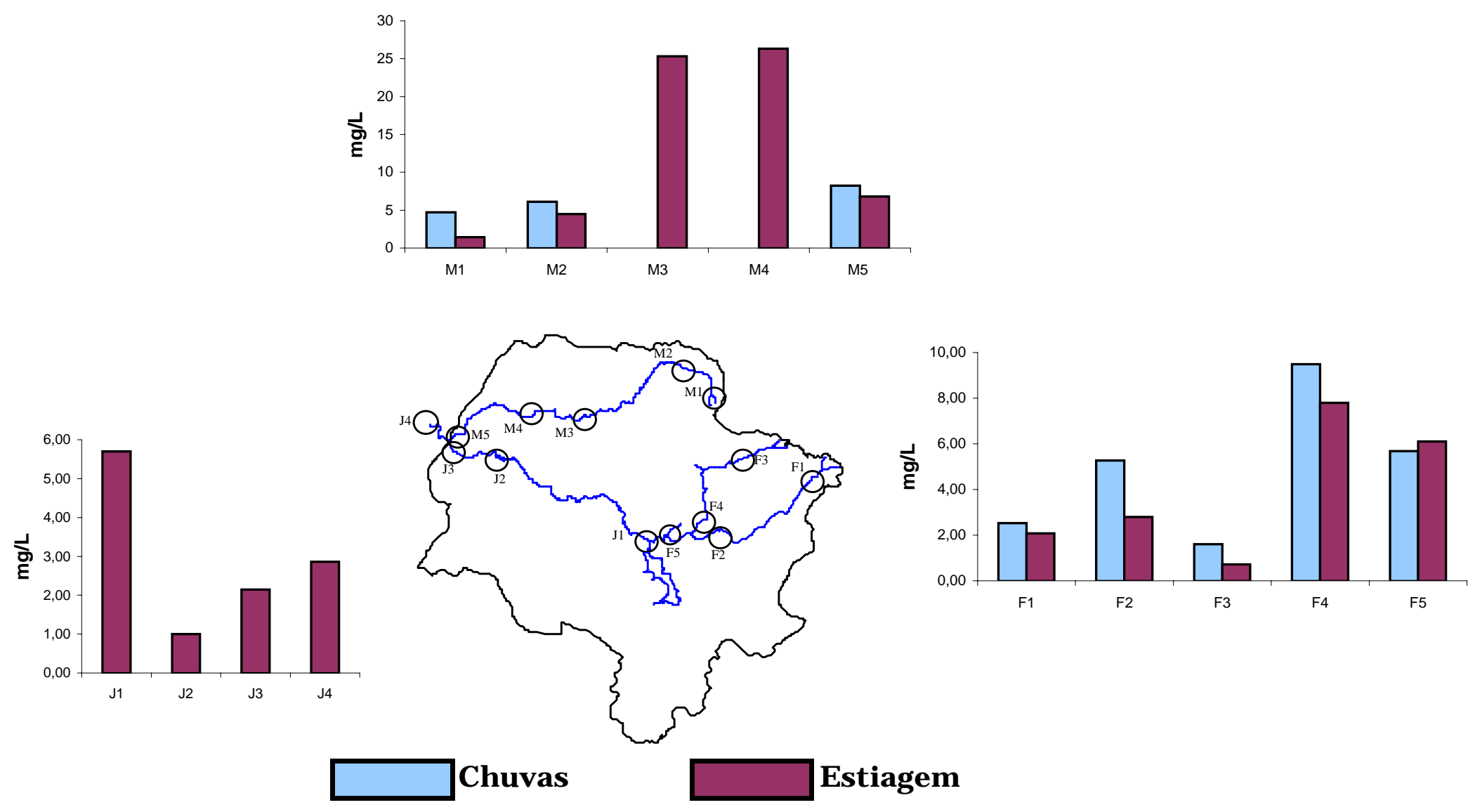

Figura 6. Valores de MSƠmg/L), na bacia hidrográfica do Alto Jacaré-Guaçu, nos períodos de estudo. 
A DQO só foi analisada no período de estiagem e seus maiores valores foram obtidos nos pontos M3 (56mgL-1), M4 (46mgL-1) e M5 (22mgL-1), localizados após a área urbana, (Tabela IX).

Tabela IX. Valores de Demanda Química de Oxigênio, na bacia hidrográfica do Alto Jacaré-Guaçu, em agosto de 1999.

\begin{tabular}{cc}
\hline $\begin{array}{c}\text { Pontos de } \\
\text { Amostragem }\end{array}$ & $\begin{array}{c}\text { DQO } \\
\left(\mathrm{mgL}^{-1}\right)\end{array}$ \\
\hline M1 & 6 \\
M2 & 6 \\
M3 & 54 \\
M4 & 46 \\
M5 & 22 \\
F1 & 9 \\
F2 & 4 \\
F3 & 4 \\
F4 & $*$ \\
F5 & 6 \\
J1 & 4 \\
J2 & 1 \\
J3 & 4 \\
J4 & 4 \\
*= não analisado &
\end{tabular}

Os valores da $\mathrm{DBO}_{5}$, no período chuvoso, de modo geral, foram muito baixos, menores do que $1 \mathrm{mgL}^{-1}$, exceção feita para o ponto M5 com $1,60 \mathrm{mgL}^{-1}$. Como já se falou no parágrafo anterior, os valores de DQO, em geral, foram menores do que $20 \mathrm{mgL}^{-1}$, indicando águas não contaminadas, exceção feita para os pontos M3, M4 e M5. Na estiagem foi decidido realizar análises de $\mathrm{DBO}_{5}$ somente nesses pontos (metodologia seguida pelo Laboratório de SaneamentoSHS/EESC). Foram obtidos valores de $\mathrm{DBO}_{5}$ de 24,00 $\mathrm{mgL}^{-1}$, 19,00 $\mathrm{mgL}^{-1}$ e $11, \mathrm{OOmgL}^{-1}$, para os pontos M3, M4 e M5, respectivamente, valores superiores ao padrão da Resolução CONAMA 20, que é de $5 \mathrm{mgL}^{-1}$ (Tabela $\mathrm{X}$ ). 
Tabela X. Valores da Demanda Bioquímica de Oxigênio, na bacia hidrográfica do Alto Jacaré-Guaçu, nos dois períodos estudados.

\begin{tabular}{|c|c|c|}
\hline $\begin{array}{c}\text { Pontos de } \\
\text { Amostragem }\end{array}$ & $\begin{array}{l}\text { Período chuvoso } \\
\qquad\left(\mathrm{mgL}^{-1}\right)\end{array}$ & $\begin{array}{l}\text { Período de estiagem } \\
\qquad\left(\mathrm{mgL}^{-1}\right)\end{array}$ \\
\hline M1 & 0,52 & $* *$ \\
\hline M2 & 0,07 & $* *$ \\
\hline M3 & $*$ & 24,00 \\
\hline M4 & $*$ & 19,00 \\
\hline M5 & 1,60 & 11,00 \\
\hline $\mathrm{F} 1$ & 0,54 & $* *$ \\
\hline $\mathrm{F} 2$ & 0,61 & $* *$ \\
\hline F3 & 0,14 & $* *$ \\
\hline $\mathrm{F} 4$ & 0,85 & $* *$ \\
\hline F5 & 0,34 & $* *$ \\
\hline $\mathrm{J} 1$ & $*$ & $* *$ \\
\hline $\mathrm{J} 2$ & * & $* *$ \\
\hline J3 & $*$ & $* *$ \\
\hline $\mathrm{J} 4$ & $*$ & $* *$ \\
\hline $\begin{array}{ll}* & = \\
* * & =\end{array}$ & $\begin{array}{l}\text { lão amostrado } \\
\text { lão analisado }\end{array}$ & \\
\hline
\end{tabular}

3.3.4 Variáveis indicadoras de eutrofização: nitrogênio Kjeldahl, amônia, nitrito, nitrato e fósforo total

Os valores de nitrogênio orgânico variaram, na época das chuvas, de $0,26 \mathrm{mgL}^{-1}$ (no ponto F1) a $1,19 \mathrm{mgL}^{-1}$ (no ponto M5). No período de estiagem, as concentrações estiveram entre $0,80 \mathrm{mgL}^{-1}$ (F2 e F3) e 5,60mgL-1 (M4 e F1), como apresentado na Figura 7.

Em relação a amônia obtiveram-se valores entre $0,034 \mathrm{mgL}^{-1}$ (F3) e $0,178 \mathrm{mgL}^{-1}$ (M5), no período chuvoso. Já no período de estiagem, os valores variaram de $0,050 \mathrm{mgL}^{-1}$ (F2) a 3,100mgL-1 (M3). A Resolução CONAMA 20 fixa um valor de 0,020mgL-1 para amônia não ionizável. No caso do ponto M3, que apresentou a máxima concentração do íon amônio $\left(3,100 \mathrm{mgL}^{-1}\right)$, o valor de amônia não ionizável é de 0,004mgL-1, (Figura 8). 

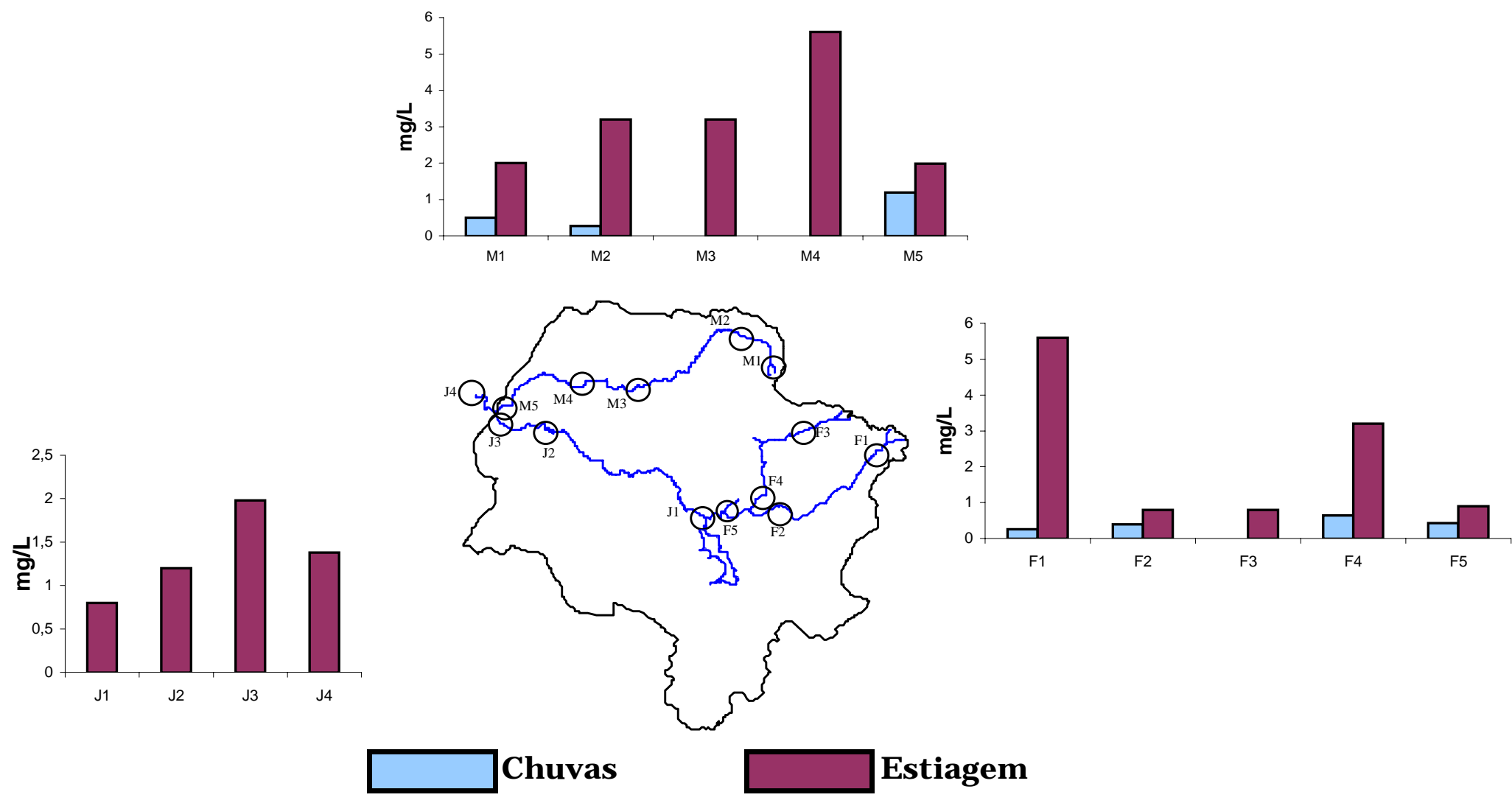

Figura 7. Concentração de nitrogênio orgâni(mg/L), na bacia hidrográfica do Alto Jacaré-Guaçu, nos períodos de estudo. 


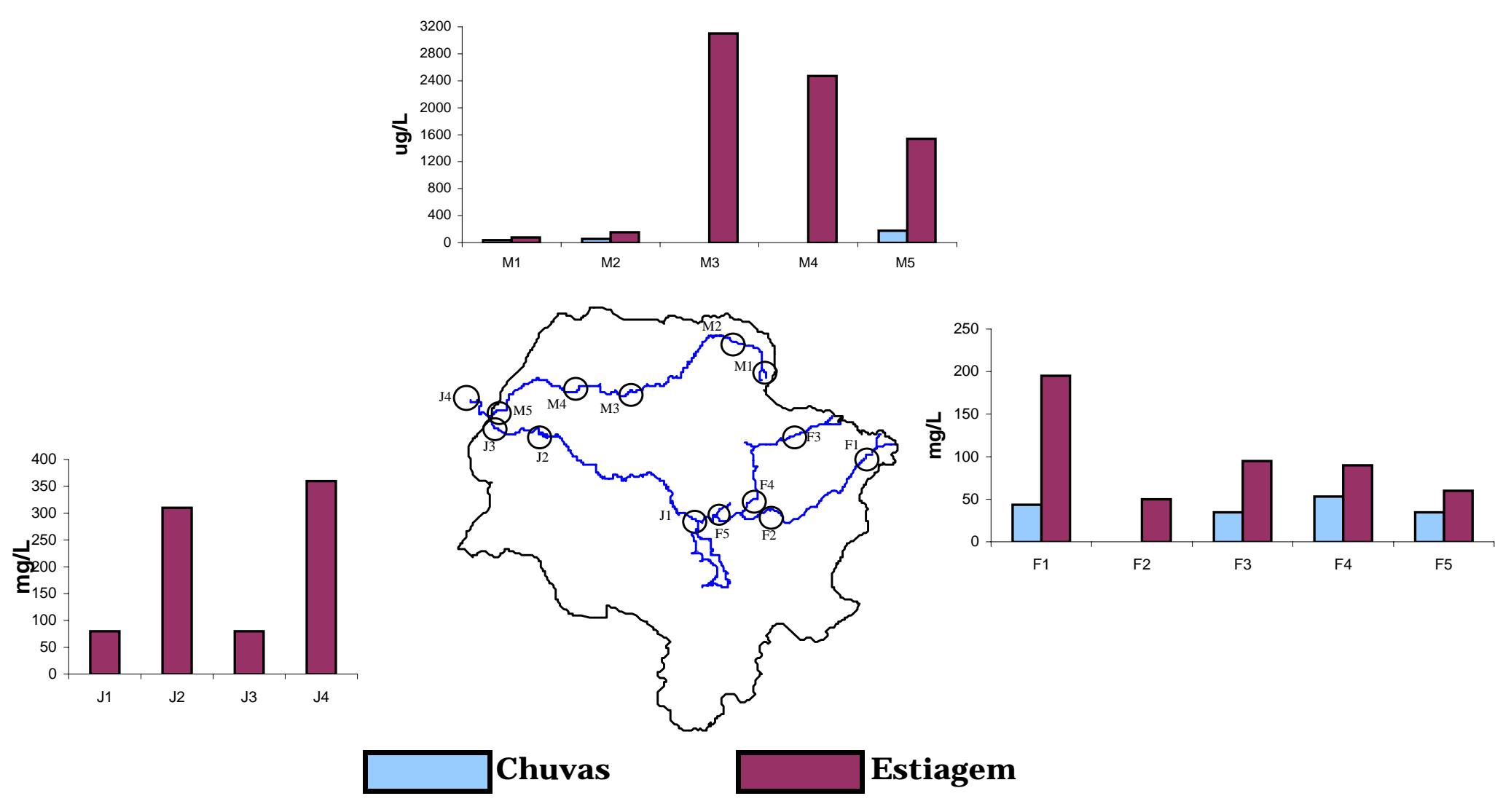

Figura 8. Concentração de íon amôn(mg/L), na bacia hidrográfica do Alto Jacaré-Guaçu, nos períodos de estudo. 
Os valores de nitrito, em geral, foram baixos nas duas épocas de coleta, variando de $0,002 \mathrm{mgL}^{-1}$ a $0,008 \mathrm{mgL}^{-1}$; com exceção do ponto M5, com uma concentração de $0,061 \mathrm{mgL}^{-1}$, no período das chuvas e de 0,070 $\mathrm{mgL}^{-1}$, na estiagem. A Resolução CONAMA 20 fixa um valor de 1,000 $\mathrm{mgL}^{-1}$ (Figura 9).

As concentrações de nitrato variaram de $0,090 \mathrm{mgL}^{-1}$ (M2) a 0,490 $\mathrm{mLL}^{-1}$ (M1), no período das chuvas. Já as concentrações no período de estiagem foram de $0,230 \mathrm{mgL}^{-1}$ (M2) a $0,930 \mathrm{mgL}^{-1}$ (F1). A Resolução CONAMA 20 fixa um valor de 10,000 mg.L.'-1 (Figura 10).

Em relação aos valores das concentrações de fósforo total, na época das chuvas não se verificou muita variação, com valores entre 0,042 $\mathrm{mgL}^{-1}$ (F2) e 0,067 $\mathrm{mgL}^{-1}$ (M5). Em agosto, as concentrações foram de 4 até 24 vezes maiores que as apresentadas no período das chuvas, com as maiores concentrações obtidas nos pontos M3, M4 e M5 (1,230 $\mathrm{mLL}^{-1}, \quad 1,550 \mathrm{mgL}^{-1}$ e $1,570 \mathrm{mgL}^{-1}$, respectivamente). A resolução CONAMA 20 estabelece um limite de $0,025 \mathrm{mgL}^{-1}$ para corpos de água Classe 2 (Figura 11). 


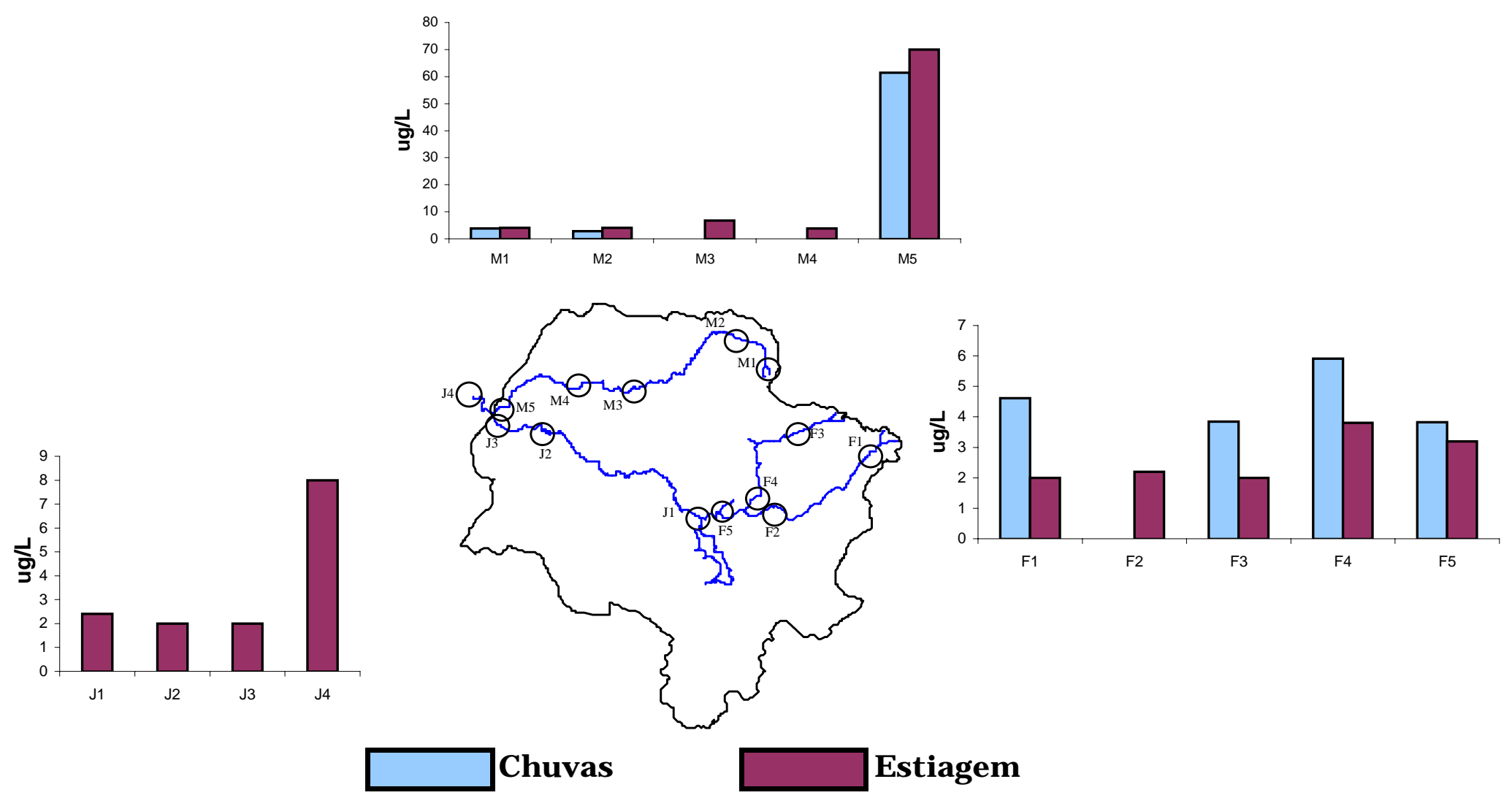

Figura 9. Concentração de nitrit(og/L), na bacia hidrográfica do Alto Jacaré-Guaçu, nos períodos de estudo. 


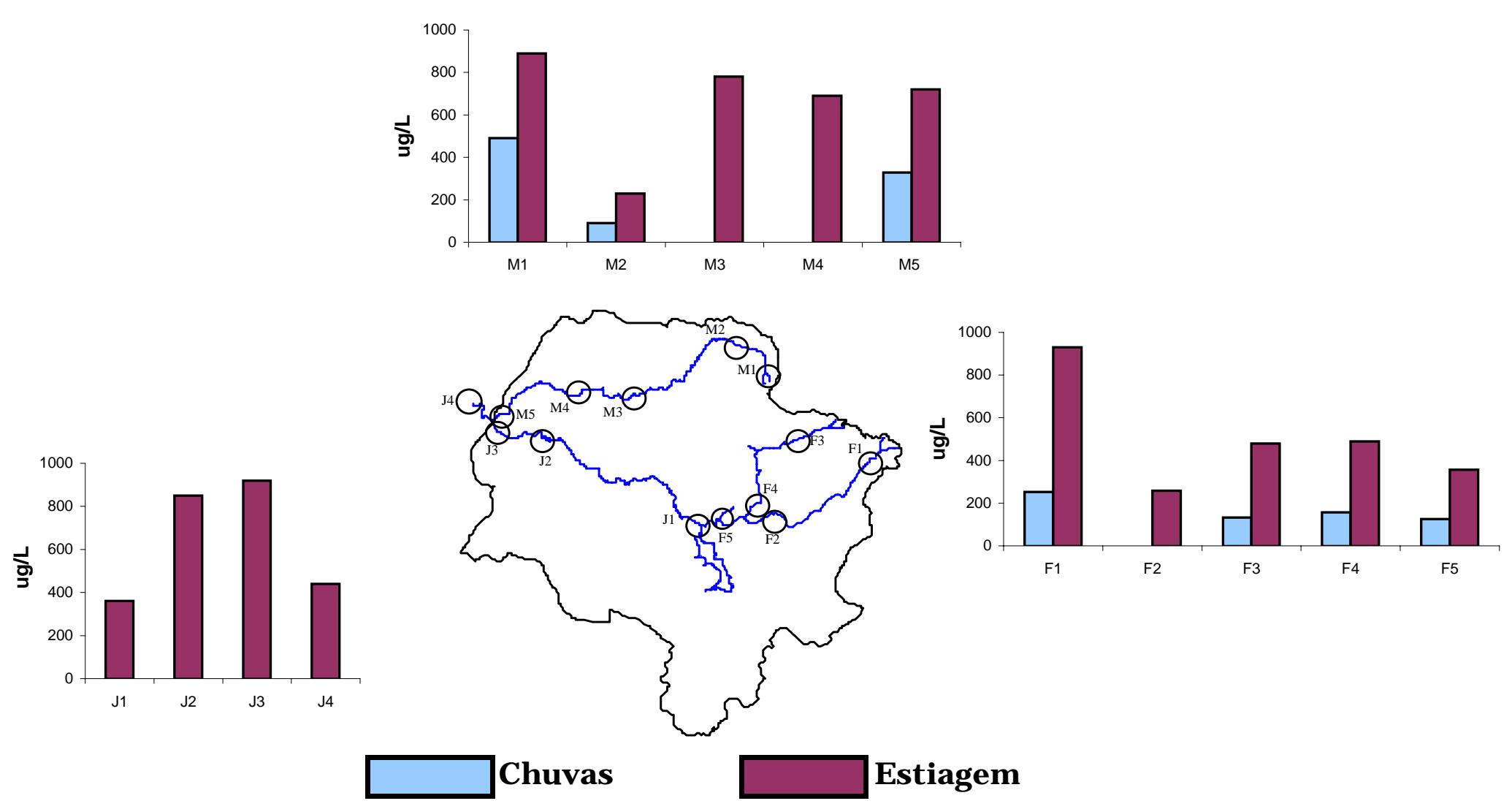

Figura 10. Concentração de nitrat(øg/L), na bacia hidrográfica do Alto Jacaré-Guaçu, nos períodos de estudo. 


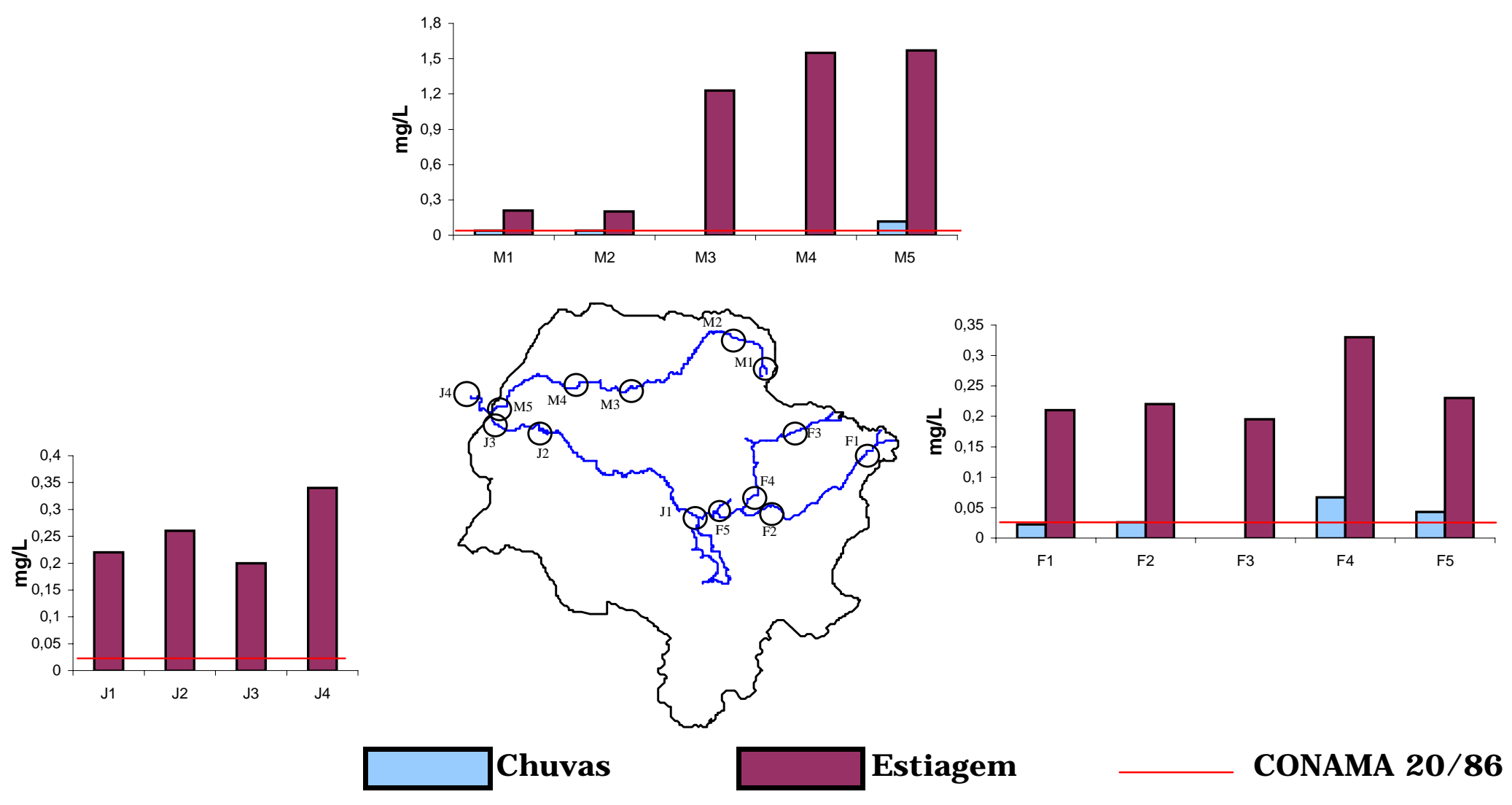

Figura 11. Concentração de fósforo tot(æhg/L), na bacia hidrográfica do Alto Jacaré-Guaçu, nos períodos de estudo. 
3.3.5 Índice do estado trófico

Os resultados referentes à classificação do estado trófico, segundo o índice de Carlson (modificado) para os dois períodos estudados, são apresentados nas tabelas IX e X.

Tabela XI. Classificação do estado trófico, segundo o Índice de Carlson (modificado) para o período chuvoso, na bacia do Alto Jacaré-Guaçu.

\begin{tabular}{cccc}
\hline $\begin{array}{c}\text { Ponto de } \\
\text { amostragem }\end{array}$ & $\begin{array}{c}\text { Fósforo total } \\
\left(\mathrm{mgm}^{-3}\right)\end{array}$ & $\begin{array}{c}\text { Índice do } \\
\text { estado trófico }\end{array}$ & Estado trófico \\
\hline M1 & 49 & 2 & Mesotrófico \\
M2 & 49 & 2 & Mesotrófico \\
M5 & 65 & 3 & Eutrófico \\
F1 & 42 & 2 & Eutrófico \\
F2 & 44 & 2 & Mesotrófico \\
F3 & $*$ & $*$ & $*$ \\
F4 & 57 & 3 & Eutrófico \\
F5 & 51 & 2 & Mesotrófico \\
\hline * não analisado & & &
\end{tabular}

Tabela XII. Classificação do estado trófico, segundo o Índice de Carlson, modificado, para o período seco, na bacia do Alto Jacaré-Guaçu.

\begin{tabular}{cccl}
\hline $\begin{array}{c}\text { Ponto de } \\
\text { amostragem }\end{array}$ & $\begin{array}{c}\text { Fósforo total } \\
\left(\mathrm{mgm}^{-3}\right)\end{array}$ & $\begin{array}{c}\text { Índice do estado } \\
\text { trófico (IET) }\end{array}$ & Estado trófico \\
\hline M1 & 210 & 3 & Eutrófico \\
M2 & 202 & 3 & Eutrófico \\
M3 & 1.230 & 4 & Hipereutrófico \\
M4 & 1.550 & 4 & Hipereutrófico \\
M5 & 1.570 & 4 & Hipereutrófico \\
F1 & 210 & 3 & Eutrófico \\
F2 & 220 & 4 & Hipereutrófico \\
F3 & 195 & 3 & Eutrófico \\
F4 & 330 & 4 & Hipereutrófico \\
F5 & 230 & 4 & Hipereutrófico \\
J1 & 220 & 4 & Hipereutrófico \\
J2 & 260 & 4 & Hipereutrófico \\
J3 & 200 & 3 & Eutrófico \\
J4 & 340 & 4 & Hipereutrófico \\
\hline
\end{tabular}


Os resultados obtidos com a aplicação do Índice de Carlson, modificado por TOLEDO et al. (1983), indicam que os corpos de água que compõem a bacia do Alto Jacaré-Guaçu, no período chuvoso, enquadram-se entre mesotróficos (valores acima de 25 até 54) e eutróficos (valores acima de 54 até 74). Já no período seco, enquadram-se como eutróficos (valores acima de 54 até 74) e hipereutróficos (valores acima de 74).

\subsubsection{Análise estatística}

A análise dos componentes principais realizada com as variáveis físicas e químicas, utilizando os locais de amostragem como variável a ser discriminada, revelou claramente as diferenças entre os pontos amostrais da bacia hidrográfica em estudo. Na figura 12 se indica a distribuição dos pontos amostrados a partir da análise de componentes principais, para o período das chuvas.

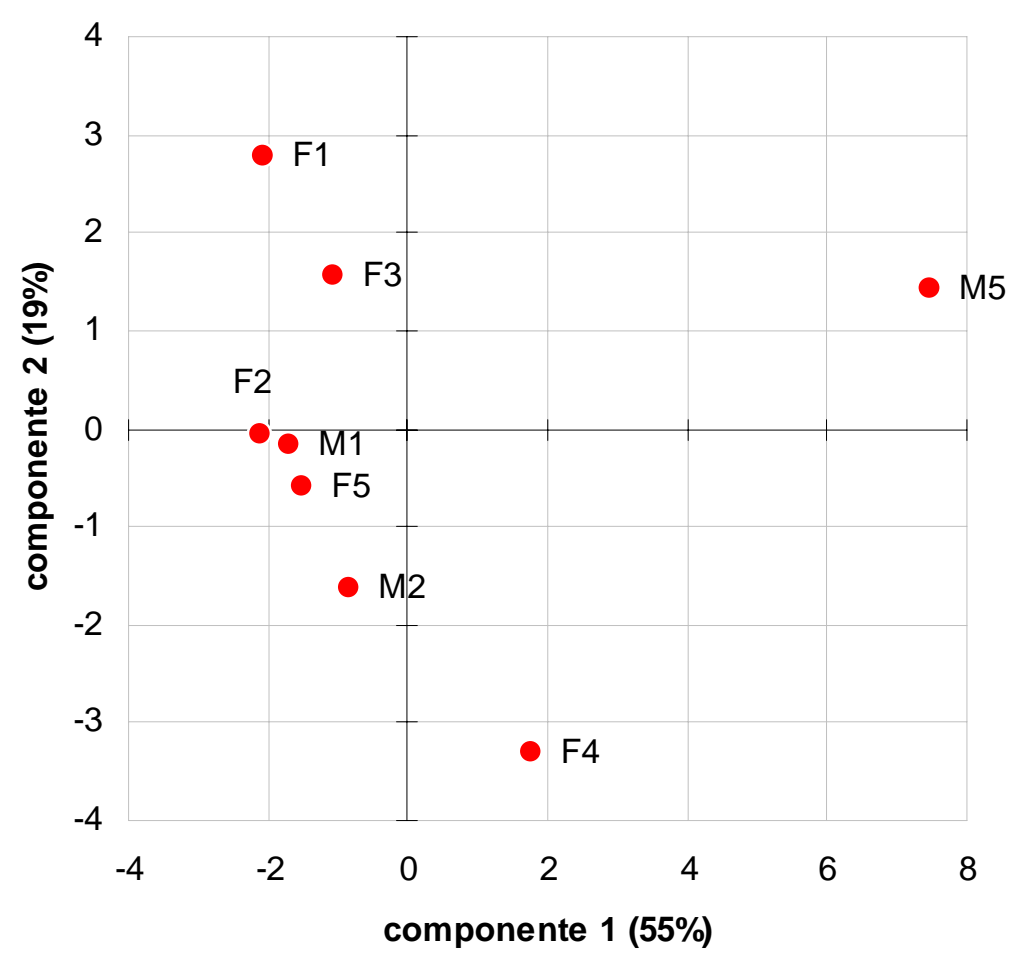

Figura 12. Gráfico da análise de componentes principais, para o período das chuvas, na bacia do Alto Jacaré-Guaçu. 
Os dois eixos explicam conjuntamente $74 \%$ da variabilidade dos agrupamentos, sendo que o eixo das abscissas é responsável pela explicação de $55 \%$ e o eixo das ordenadas por $19 \%$.

Como se pode observar na figura 12 , o componente 1 , representada no eixo das abscissas, separou os locais de coleta em 2 grupos, um correspondente à estação M5, localizada após a área urbana, e outro representando as demais estações amostrais em seqüência, que correspondem aos pontos F1, F3, F2, M1, F5, M2 e F4.

Analisando a tabela XIII, onde se encontram os valores das variáveis analisadas tem-se que no componente 1 , responsável pela explicação de 55\% do agrupamento, as variáveis que melhor explicam a separação entre o ponto M5 e os outros pontos de coleta são: oxigênio dissolvido, carbono dissolvido total e inorgânico, $\mathrm{DBO}_{5}$, fosfato total, nitrogênio Kjeldahl, íon amônio e nitrito, evidenciando que a distinção entre os grupos formados na análise é explicada pela poluição provocada pelos despejos dos esgotos (matéria orgânica e nutrientes) da cidade de São Carlos.

No eixo das ordenadas, componente 2, responsável pela explicação de 19\%, a variável que mais influencia positivamente para o deslocamento do ponto $\mathrm{F} 1$ é o oxigênio dissolvido, enquanto que o ponto F4 é deslocado negativamente pelos materiais em suspensão totais, orgânicos e inorgânicos. Tal fato provavelmente reflete a ausência de mata ciliar nas margens desse ponto (F4). 
Tabela XIII. Valores das variáveis analisadas no período das chuvas na bacia do Alto Jacaré-Guaçu.

\begin{tabular}{ccc}
\hline Variável & Componente 1 & Componente 2 \\
\hline pH & 0.2524 & 0.2700 \\
oxigênio diss. & -0.0596 & 0.4047 \\
condutividade & 0.2990 & 0.2041 \\
turbidez & 0.2243 & -0.3260 \\
MST & 0.2008 & -0.3776 \\
MSI & 0.1959 & -0.3703 \\
MSO & 0.2115 & -0.3835 \\
CDT & 0.3007 & 0.2001 \\
CDI & 0.2819 & 0.1728 \\
CDO & 0.0530 & 0.0758 \\
DBO 5 & 0.2810 & 0.0647 \\
nitrogênio kjeldahl & 0.3005 & 0.0669 \\
fósforo total & 0.3062 & 0.0213 \\
ion amonio & 0.3132 & 0.0668 \\
nitrito & 0.3063 & 0.1586 \\
nitrato & 0.0753 & 0.1615 \\
\hline
\end{tabular}

$\mathrm{Na}$ figura 13 podem ser visualizadas as diferenças para $\mathrm{o}$ período de estiagem. Como pode ser observado na figura 13, para o período de inverno a função discriminante 1 , representada no eixo das abscissas, separou os locais de coleta em 3 grupos: um correspondente aos pontos F1, F4, F2, J1, J2, J3, M1, M2, J4 e F3, localizados antes ou sem influência da área urbana; outro com os pontos localizados após a área urbana e que refletem o impacto dos despejos urbanos, pontos M3 e M4, e o último representado pelo ponto M5, que indica o processo de recuperação do Rio Monjolinho. 


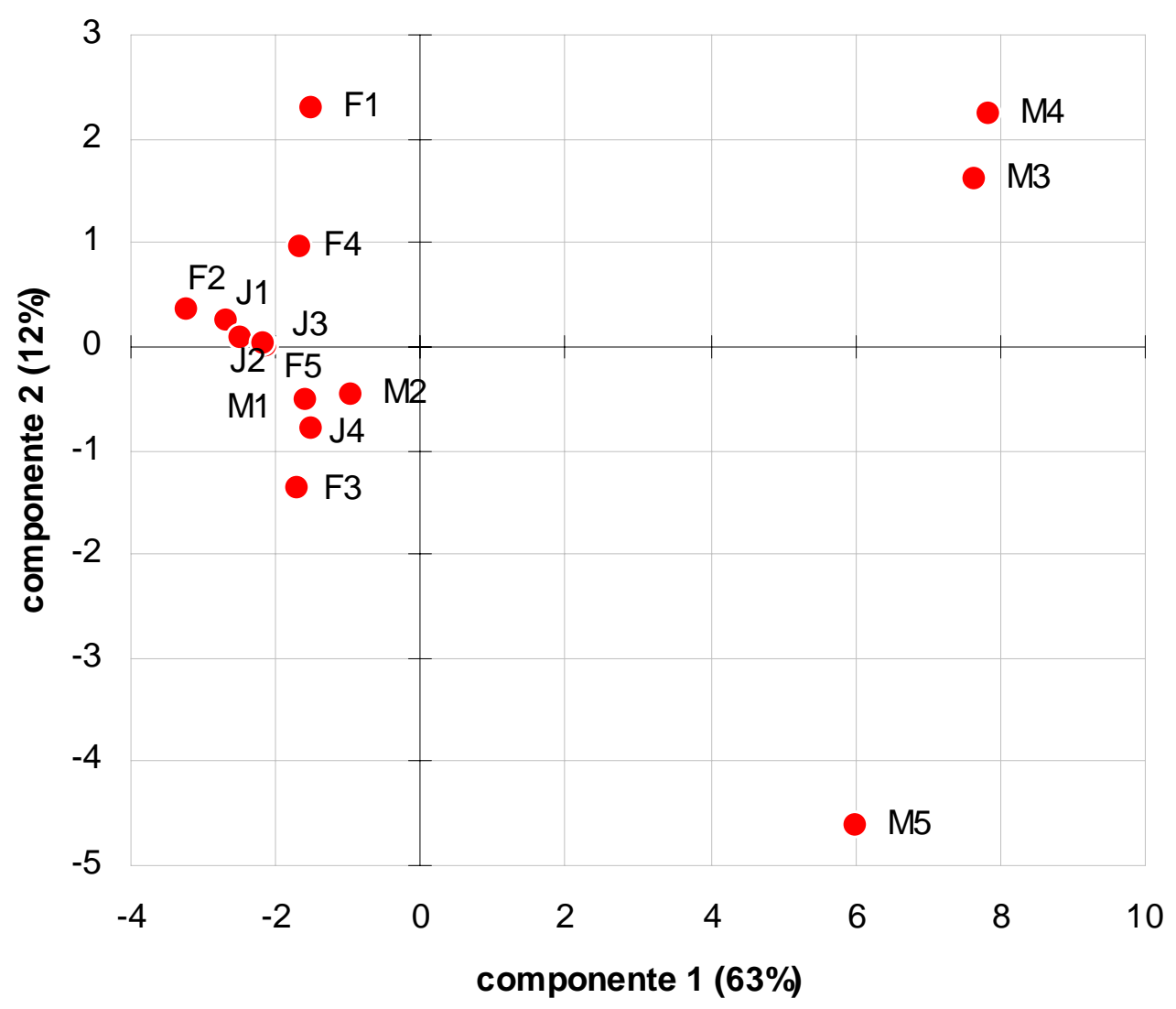

Figura 13. Gráfico da análise de componentes principais, para o período de estiagem, na bacia do Alto Jacaré-Guaçu.

Na tabela XIV, onde se encontram os valores das variáveis analisadas, tem-se que no componente 1 , responsável pela explicação de $63 \%$ do agrupamento, as variáveis que melhor explicam a separação entre os 3 grupos são condutividade elétrica, turbidez, íns, matéria orgânica, fosfato e íon amônio, evidenciando, novamente, o efeito poluidor dos esgotos urbanos.

No eixo das ordenadas, componente 2 , responsável pela explicação de $12 \%$, as variáveis que mais influenciam são o oxigênio dissolvido e o nitrogênio para os pontos M3 e M4 e o nitrito, o qual apresenta uma alta concentração $\left(0,070 \mathrm{mgL}^{-1}\right)$ para o ponto M5. 
Tabela XIV. Valores das variáveis analisadas na análise de componentes principais, para o período de inverno, na bacia do Alto Jacaré-Guaçu.

\begin{tabular}{ccc}
\hline Variável & Componente 1 & Componente 2 \\
\hline pH & 0.1522 & -0.1932 \\
oxigênio diss. & -0.1114 & 0.4665 \\
condutividade & 0.2555 & -0.0930 \\
turbidez & 0.2430 & 0.1802 \\
MST & 0.2266 & 0.2574 \\
MSI & 0.2253 & 0.2633 \\
MSO & 0.2261 & 0.2500 \\
alcalinidade & 0.2532 & -0.1406 \\
dureza & 0.2559 & -0.1105 \\
cálcio & 0.2531 & -0.0280 \\
magnésio & 0.1702 & -0.1120 \\
sódio & 0.2582 & -0.0703 \\
potássio & 0.2366 & -0.0218 \\
bicarbonatos & 0.2532 & -0.1406 \\
sulfatos & 0.2014 & 0.0766 \\
cloretos & 0.0583 & -0.1802 \\
DQO & 0.2437 & 0.1852 \\
nitrogênio kjeldahl & 0.1343 & 0.3338 \\
fósforo total & 0.2535 & -0.0824 \\
ion amonio & 0.2529 & 0.0942 \\
nitrito & 0.1267 & -0.4652 \\
nitrato & 0.0760 & 0.0789 \\
\hline
\end{tabular}

\subsection{DISCUSSÃO}

O pH é uma importante variável na avaliação da qualidade da água influenciada por processos biológicos e químicos dentro do corpo da água. A bacia do Alto Jacaré-Guaçu drena solos de cerrado cujo pH é bastante ácido (PRADO et. al. 1981), do qual resultam águas com características ácidas, principalmente no período das chuvas pela ação da lavagem dos mesmos. Além do $\mathrm{pH}$, as chuvas também influenciam os valores de turbidez, os quais, em geral, foram da ordem de cinco vezes maiores aos do período de estiagem. 
Os valores de condutividade da água nos diferentes pontos amostrados foram, em geral, baixos, devido principalmente à pedologia da região, com exceção dos pontos após área urbana, os quais refletem, além da constituição do solo, a grande contribuição dos esgotos domésticos e industriais vertidos sobre o Rio do Monjolinho.

As concentrações dos íons maiores são muito variáveis na águas superficiais devido à geologia, clima, condições geográficas e influência antrópica (CHAPMAN, 1992). Para o cálcio, sódio e bicarbonato verificou-se um comportamento similar a alcalinidade e dureza, com valores máximos após a área urbana, o que confirma o impacto dos esgotos municipais (domésticos e industriais). Para potássio, além da ocorrência de valores máximos após a área urbana, também foi verificada uma alta concentração no ponto F1 devido, provavelmente, ao uso de fertilizantes, já que próximo a este local de coleta existem culturas anuais de milho. Para o cloreto observou-se um comportamento similar ao cálcio, sódio e bicarbonato, com as maiores concentrações após a área urbana e no ponto F3, devido provavelmente a assentamentos humanos com criação de animais a montante do ponto de coleta.

Com relação aos sulfatos o comportamento foi semelhante a do potássio, já que para os pontos localizados no Rio Monjolinho e o ponto F1 (nascente do Ribeirão do Feijão) foram registradas concentrações de sulfatos em ordem de magnitude superior à dos outros pontos da bacia do Alto Jacaré-Guaçu, provavelmente devido à aplicação de adubos, a litologia do solo e, no caso do ponto M3, também aos esgotos municipais da cidade de São Carlos. Comportamento semelhante a do cloreto foi verificado para magnésio, com maiores concentrações na bacia do Monjolinho e no ponto F3, mas em geral seus valores foram baixos. 
A faixa de concentrações de íons dos principais rios do mundo e a concentração natural mais comum (CNMC) encontrada nos rios está apresentada na tabela XV (Segundo MEYBECK, 1996).

Tabela XV. Faixa de concentrações de íons dos principais rios do mundo, concentração natural mais comum (CNMC) e pontos amostrados no Alto Jacaré-Guaçu, sem influência urbana (M1, M2, F1, F2, F3, F4, F5, J1, J2, J3) e com influência (M3, M4 e M5), valores em mgL-1

\begin{tabular}{|c|c|c|c|c|}
\hline & \multirow{2}{*}{$\begin{array}{l}\text { Principais rios do } \\
\text { mundo }\end{array}$} & \multirow[t]{2}{*}{ CNMC } & \multicolumn{2}{|c|}{ Alto Jacaré-Guaçu } \\
\hline & & & $\begin{array}{c}\text { Sem influência } \\
\text { urbana }\end{array}$ & $\begin{array}{c}\text { Com influência } \\
\text { urbana }\end{array}$ \\
\hline Cálcio & $2-50$ & 8,00 & 6,50 & 22,20 \\
\hline Magnésio & $1,30-25$ & 3,70 & 0,60 & 1,00 \\
\hline Sódio & $0,85-12,10$ & 2,40 & 0,90 & 8,80 \\
\hline Potássio & $0,50-3,90$ & 1,00 & 1,20 & 3,60 \\
\hline Bicarbonato & $10-170$ & 30,50 & 8,90 & 45 \\
\hline Sulfato & $2,20-48$ & 4,80 & 4,30 & 13,70 \\
\hline Cloreto & $0,60-25$ & 3,90 & 4,20 & 7,80 \\
\hline
\end{tabular}

Segundo as concentrações de íons detectadas e tomando como base a concentração natural em rios (CNMC) apresentada na Tabela $\mathrm{XV}$, os pontos de amostragem da bacia hidrográfica do Alto JacaréGuaçu podem ser divididos em 2 grupos: os pontos sem influência urbana (M1, M2, F1, F2, F3, F4, F5, J1, J2, J3), que apresentam condições relativamente naturais e os pontos com influência urbana (M3, M4 e M5), os quais apresentam-se seriamente impactados.

Segundo CHAPMAN (1992), o termo sólidos é amplamente usado para a maioria dos compostos que estão presentes nas águas naturais e permanecem em um estado sólido após evaporação. Os sólidos possuem importante papel em estudos de ecossistemas aquáticos, sendo, em alguns casos, os maiores responsáveis pela regulação e limitação da penetração de luz (sólidos suspensos), podendo também interferir na concentração de oxigênio e na 
condutividade elétrica, contendo nutrientes e poluentes (partículas de metais, entre outros). A concentração de sólidos nos ecossistemas lóticos está ligada a inúmeros fatores, dentre eles, a precipitação pluviométrica, existência de regiões de corredeiras, alterações nas margens, desmatamento de áreas vizinhas e constituição do solo.

Pela variação da concentração do material em suspensão orgânico verificou-se os valores mais baixos nos pontos próximos às nascentes; já os mais altos ocorreram nos pontos após a área urbana (M3, M4 e M5) e no ponto F4. Tal fato pode ser explicado, nos pontos M3, M4 e M5, pelos despejos orgânicos dos esgotos da cidade de São Carlos e no ponto F4 pela da ausência de mata ciliar, característica deste ponto de amostragem.

A demanda química de oxigênio (DQO) é uma medida equivalente à matéria orgânica em amostras de água que é suscetivel à oxidação por um oxidante químico forte, como é o dicromato de potássio. A DQO é amplamente usada como uma medida da quantidade de materiais orgânicos e inorgânicos presentes no corpo de água e nos efluentes industriais e domésticos, suscetíveis à oxidação. As concentrações de DQO observadas em águas superficiais podem ser de $20 \mathrm{mgL}^{-1}$ ou menos em águas não poluídas, ou até de 200mgL-1 em água recebendo efluentes (CHAPMAN, 1992). Os valores de DQO, no sistema estudado, estiveram dentro de uma faixa normal para águas superficiais não contaminadas, com valores inferiores a 20mgL-1 (CHAPMAN, 1992), com exceção dos pontos M3 (56mgL-1), M4 (46mgL-1) e M5 (22mgL-1), localizados após a área urbana e que, portanto, revelam o excesso de matéria orgânica oriunda dos despejos urbanos não tratados. Observa-se, no entanto, uma autodepuração no corpo de água, já que os valores de DQO vão decrescendo após a área urbana.

De uma forma geral, os valores das concentrações dos nutrientes foram maiores após a área urbana de São Carlos, evidenciando o esgoto doméstico e industrial como sua principal 
fonte. Esses valores se incrementam ainda mais no período de estiagem devido à diminuição do fluxo de água, característica desse período.

O nitrogênio orgânico (nitrogênio Kjeldahl) consiste principalmente de substâncias protéicas (aminoácidos, ácidos nucleicos e urina) e o produto de transformações bioquímicas (ácidos húmicos e fúlvicos). Na água origina-se da decomposição de todos os organismos vivos. A ciclagem dentro da cadeia alimentar está sujeita a flutuações sazonais da comunidade biológica. Incrementos nas concentrações podem indicar poluição do corpo d'água. O fato do ponto F1 apresentar o menor valor em março e maior valor em agosto, deve-se, provavelmente, ao uso de compostos nitrogenados nas culturas anuais (milho) próximas ao ponto de coleta.

O íon nitrato é a forma mais comum de nitrogênio combinado encontrada nas águas naturais. Fontes naturais de nitrato nas águas superficiais incluem rochas ígneas, drenagem de solos e resíduos de animais e plantas. Niveis naturais raramente excedem $0,10 \mathrm{mgL}^{-1}$, mas podem ser aumentados por águas residuais industriais e domésticas. Em áreas rurais o uso de fertilizantes pode ser uma fonte significativa, provavelmente o que acontece nos pontos M1, F1, J2 e J3.

As concentrações de nitrito são usualmente muito baixas, $0,001 \mathrm{mgL}^{-1}$ e raramente maiores que $1,00 \mathrm{mgL}^{-1}$. Altas concentrações são geralmente indicadoras de efluentes industriais e são freqüentemente associadas com uma qualidade da água insatisfatória microbiologicamente (CHAPMAN, 1992), o que pode estar acontecendo no ponto M5, no qual verificou-se valores até 20 vezes com relação aos outros pontos amostrados, nos dois períodos de coleta, com um valor médio de 0,066mgL-1.

Em relação à amônia, a Resolução CONAMA 20 fixa um valor de $0,02 \mathrm{mgL}^{-1}$ para amônia não ionizável, a qual é tóxica para os peixes e depende principalmente do $\mathrm{pH}$. No caso do ponto M3, que 
apresentou a máxima concentração do íon amônio $\left(3100 \mu g L^{-1}\right)$, esta estaria ainda 5 vezes abaixo do limite, com um valor de $0.004 \mathrm{mgL}^{-1}$ de amônia não ionizável.

O fósforo é um nutriente essencial para os organismos vivos e existe nos corpos de água na forma dissolvida e particulada. Geralmente é o fator limitante da produtividade primária e incrementos artificiais nas concentrações podem indicar poluição, sendo a principal causa da eutrofização nos corpos de água. As fontes naturais de fósforo são principalmente as rochas (intemperismo) e a decomposição da matéria orgânica. Águas residuarias domésticas (particularmente contendo detergentes), efluentes industriais e fertilizantes (escoamento superficial) contribuem para a elevação dos niveis de fósforo nas águas superficiais.

As concentrações de fósforo, na maioria das águas naturais, encontram-se entre 0,005mgL-1 e 0,020mgL-1 (CHAPMAN, 1992). As concentrações de fósforo total foram maiores em agosto (aproximadamente 10 vezes), indicando o efeito da concentração devido a estiagem apresentada no período. As maiores concentrações foram detectadas após a área urbana e que, portanto, refletem a grande contribuição dos esgotos domésticos e industriais não tratados. Outro fator que pode elevar as concentrações de fósforo total na água no trecho após a área urbana são as atividades agroindustriais, principalmente o predomínio da monocultura de cana-deaçúcar e, por conseguinte, o uso de fertilizantes usados nas culturas, os quais, por lixiviação e falta de mata ciliar, chegam até as margens do rio e de seus afluentes. A resolução CONAMA 20 estabelece um limite de $0,025 \mathrm{mgL}^{-1}$ para corpos de água classe 2. Assim, só o ponto F1, na coleta de março, esteve dentro desse limite.

Para comparar os resultados obtidos no presente trabalho, com os reportados na literatura (SÉ, 1992; TEIXEIRA, 1993; GUERESCHI, 1995 e SILVA, 1998), elaborou-se a Tabela XVI. 
Tabela XVI. Valores de nutrientes $\left(\mu \mathrm{gL}^{-1}\right)$ do Rio do Monjolinho e Ribeirão do Feijão em coletânea de vários trabalhos na literatura para intercomparação com os resultados encontrados no presente trabalho.

\begin{tabular}{|c|c|c|c|c|c|c|}
\hline & & Fósforo total & $\begin{array}{c}\text { Nitrogênio } \\
\text { orgânico }\end{array}$ & Amônia & Nitrato & Nitrito \\
\hline \multicolumn{7}{|l|}{ Rio do Monjolinho } \\
\hline \multirow[t]{3}{*}{ Sé } & M1 & 46 & 1465 & 42 & 721 & 2 \\
\hline & M3 & 772 & 7458 & 2975 & 574 & 47 \\
\hline & M5 & 376 & 5529 & 2353 & 472 & 67 \\
\hline \multirow[t]{3}{*}{ GUERESCHI } & M1 & 29 & 718 & 27 & 483 & 1 \\
\hline & M3 & 984 & 6005 & 2325 & 294 & 3 \\
\hline & M5 & 763 & 5820 & 2937 & 272 & 44 \\
\hline \multirow[t]{3}{*}{ Presente trabalho } & M1 & 210 & 2000 & 76 & 890 & 4 \\
\hline & M3 & 1230 & 3200 & 3100 & 780 & 7 \\
\hline & M5 & 1570 & 1980 & 1540 & 720 & 70 \\
\hline \multicolumn{7}{|l|}{ Ribeirão do Feijão } \\
\hline \multirow[t]{3}{*}{ TEIXEIRA } & F1 & 23 & 293 & 48 & 167 & 2 \\
\hline & L1 & 33 & 437 & 99 & 172 & 4 \\
\hline & F3 & 31 & 389 & 53 & 124 & 2 \\
\hline \multirow[t]{3}{*}{ SILVA } & $\mathrm{F} 1$ & 26 & 328 & 56 & 73 & 1 \\
\hline & L1 & 44 & 129 & 60 & 93 & 1 \\
\hline & F3 & 40 & 88 & 30 & 68 & 1 \\
\hline \multirow[t]{3}{*}{ Presente trabalho } & F1 & 210 & 5600 & 195 & 930 & 2 \\
\hline & L1 & 330 & 3200 & 90 & 489 & 4 \\
\hline & F3 & 230 & 900 & 60 & 357 & 3 \\
\hline
\end{tabular}

(SÉ, 1992); (GUERESCHI, 1995); (TEIXEIRA, 1993); (SILVA, 1998) e (Presente trabalho).

Comparando-se os resultados das concentrações de nutrientes do presente estudo com os obtidos por Sé (1992) e GUERECHI (1995), para os pontos amostrados M1, M3 e M5 da sub-bacia do Monjolinho, verifica-se o aumento das concentrações de fósforo total e dos compostos nitrogenados, exceto para nitrogênio orgânico nos pontos M3 e M5 e amônia no ponto M5, o que significa que nessa sub-bacia, o ponto M1, nascente do Rio do Monjolinho, é o que vem apresentando um maior aumento na trofia na última década devido, 
provavelmente, às atividades agropastoris em suas margens e ausência de mata ciliar.

Com referência a sub-bacia do Feijão, o impacto das atividades agropastoris (principal uso do solo nessa sub-bacia) é ainda maior, já que os valores das concentrações dos nutrientes obtidos nos três pontos amostrados (F1, F4 e F5) foram na ordem de até 20 vezes maiores que os reportados por TEIXEIRA (1993) e SILVA FILHO (1998). 


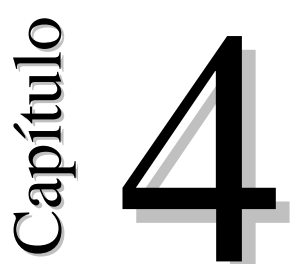

\section{ANÁLISE DA CONTAMINAÇÃO POR METAIS NA BACIA HIDROGRÁFICA DO ALTO JACARÉ-GUAÇU}

\subsection{INTRODUÇÃO}

A capacidade de um corpo de água de suportar vida aquática, como também sua conveniência para outros usos depende, entre outros, de elementos traço. Metais como, por exemplo, $\mathrm{Mn}, \mathrm{Zn}$ e $\mathrm{Cu}$ em concentrações traço são importantes para as funções fisiológicas de organismos e para regular muitos processos bioquímicos. Porém, o mesmo metal lançado em corpos da água em altas concentrações (provenientes de esgotos e efluentes industriais ou de mineração), pode ter efeitos toxicológicos severos aos organismos que vivem e/ou aos que se suprem desse corpo da água.

Os metais nos corpos da água podem existir nas formas dissolvidas, coloidais e particuladas. A proporção destas formas varia dependendo do metal e das condições ambientais do corpo da água e, conseqüentemente, a toxicidade e sedimentação potencial do metal depende destas formas. A toxicidade dos metais na água depende do grau de oxidação do íon do metal determinado junto com as formas nas quais ocorre. Por exemplo, para o cromo a Resolução CONAMA 20/86 fixa uma concentração máxima permissivel para o $\mathrm{Cr}^{6+}$ de $0,05 \mu \mathrm{gL}^{-1}$ e para o $\mathrm{Cr}^{3+}$ de $0,5 \mu \mathrm{gL}^{-1}$. Como regra, a forma iônica do metal é mais tóxica. Porém, a toxicidade é reduzida se os íons são complexados (absorvidos), como, por exemplo, pela matéria orgânica.

Dentre os vários processos poluidores a entrada e acúmulo de substâncias tóxicas nos sistemas aquáticos tem aumentado exponencialmente. Entre as substâncias tóxicas que chegam aos ecossistemas aquáticos, os metais levados por despejo de efluentes, 
transportados pela chuva e através da atmosfera, merecem especial interesse devido à ação residual e principalmente ao seu efeito cumulativo na cadeia trófica. Ultimamente, devido ao crescimento populacional e à intensificação de atividades humanas que envolvem estes elementos, a concentração de metais tem aumentado de forma generalizada nos corpos da água em níveis que ameaçam a biota aquática e também dos organismos terrestres que dela se suprem, incluindo o homem.

Uma vasta gama de atividades industriais refinam minerais metálicos, utilizam metais como matéria-prima para seus produtos ou eliminam metais como subprodutos de seus processos. As fundições (ferrosas e não ferrosas), indústrias galvanoplásticas, automobilísticas, de fertilizantes e de papel utilizam e descartam uma quantidade considerável de metais tais como cádmio, chumbo, cobre, níquel e zinco.

A poluição dos corpos da água por metais pesados resultante das atividades antrópicas está causando sérios problemas ecológicos em muitas partes do mundo. Esta situação é agravada pela falta de processos de eliminação natural dos metais (degradação). Como resultado, os metais mudam de um compartimento dentro do sistema aquático para outro, incluindo a biota (bioacumulação), através da cadeia alimentar, implicando em risco toxicológico e de saúde pública.

Como resultado de processos de adsorção e bioacumulação, a concentração de metais no sedimento é, geralmente, mais alta que a dissolvida na água. Segundo FÖRSTNER \& WITTMANN (1983) os sedimentos desempenham o papel mais importante no processo de poluição de rios por metais pesados. Eles refletem a qualidade corrente do sistema aquático e podem ser usados para detectar a presença de contaminantes que não permanecem solúveis após o seu lançamento em águas superficiais. Mais do que isso, os sedimentos agem como carreadores e possiveis fontes de poluição, pois os metais 
não são permanentemente fixados por eles e podem ser disponibilizados para a água por processos físicos, químicos, biológicos e antrópicos.

No entanto, a simples determinação da concentração total de metais nos sedimentos não traz informação, além das concentrações no referido compartimento. Ela não fornece conhecimento, por exemplo, a respeito da mobilidade ou mesmo da biodisponibilidade dos metais. Assim, a tendência de um certo elemento ser acumulado por organismos depende, em particular, da capacidade do sistema água/sedimento dispor de elementos traço removidos da solução por processos bióticos e abióticos (FORSTNER, et. al., 1990).

Portanto, nos estudos de poluição e efeitos de metais, é importante conhecer a fração móvel ou disponível destes elementos. É esta fração que será responsável pela contaminação de organismos bentônicos e da coluna da água, e que pode, conseqüentemente, acarretar a bioacumulação e a biomagnificação na biota presente.

Neste trabalho foram analisados os seguintes metais: cádmio, chumbo, cobalto, cobre, cromo, ferro, manganês, níquel, prata e zinco.

O cádmio é muito utilizado na indústria, apresenta alta afinidade pelos grupos sulfetos, o que leva a um aumento de sua solubilidade em lipídeos, sua bioacumulação e sua toxicidade. O cádmio se acumula por toda a cadeia trófica. Os valores de CL50-96h para peixes varia de 0,09 a $105 \mathrm{mgL}^{-1}$. O cádmio diminui a capacidade de osmorregulação de peixes (NAVAS-PEREIRA et. al., 1985).

O chumbo é uns dos metais tóxicos que tende a se acumular nos tecidos do homem e outros animais. No homem, a absorção do chumbo no trato digestivo varia consideravelmente com a idade: crianças absorvem até 50\%, enquanto que os adultos retêm apenas 10\% (NAVAS-PEREIRA, et. al., 1985). 
O cobalto faz parte dos oligoelementos indispensáveis ao desenvolvimento e crescimento da maior parte dos animais. Em particular, entra na composição da vitamina B12 ou cobalamina, antianémica. O cobalto não é um elemento muito abundante, mas está bastante distribuído nas rochas, no mar, em águas minerais, no carvão, nos meteoritos e em atmosferas estelares. Praticamente todo o cobalto que se utiliza no mundo provém do tratamento de minérios complexados com outros elementos, nomeadamente cobre e níquel. O cobalto e os seus compostos têm variadíssimas aplicações. São largamente usados em laboratórios e nas indústrias como catalisadores. O molibdato de cobalto, por exemplo, é um catalisador muito utilizado na indústria petrolífera para a hidrodessulfuração e reforming de petróleos (Oligoelementos On Line).

O cobre é um dos elementos essenciais para plantas e animais. É também essencial no metabolismo humano. A principal via de entrada de cobre, no homem, é pela dieta alimentar, incluindo tanto alimentos como bebidas. Entre 40\% e 70\% do cobre ingerido via oral é retido, sendo o restante eliminado pela bile, fezes e urina. O cobre acumula-se nos organismos aquáticos. Os níveis deste metal, que são tolerados sem aparecimento de sintomas de toxicidade, podem variar com a espécie animal e o período de acumulação passiva pode variar de algumas semanas a um ano (NAVAS-PEREIRA, et. al., op. cit.).

$\mathrm{O}$ cromo é encontrado na água como $\mathrm{Cr}^{3+}$ e $\mathrm{Cr}^{6+}$. $\mathrm{O} \mathrm{Cr}^{6+}$ é facilmente reduzido pelo $\mathrm{Fe}^{2+}$ e sulfetos dissolvidos. Em contraste, o $\mathrm{Cr}^{3+}$ é oxidado rapidamente pelo excesso de $\mathrm{MnO}_{2}$ e mais lentamente pelo próprio oxigênio da água. Os valores de CL50 para peixes variam de 3,5 a $118 \mathrm{mgL}^{-1}$ (NAVAS-PEREIRA, et. al., op. cit.).

O ferro e manganês são dois elementos muito freqüentes na superfície da terra. Conseqüentemente seus compostos são encontrados em todos os corpos da água, mesmo que em concentrações muito reduzidas. $O$ ferro e o manganês são micronutrientes indispensáveis ao metabolismo dos seres vivos. Estes 
elementos exercem grandes influências na ciclagem de outros nutrientes importantes como o fosfato. Além disto, têm grande relevância no metabolismo de certas bactérias capazes de obter energia necessária para a redução do $\mathrm{CO}_{2}$ a partir da oxidação das formas reduzidas de ferro e manganês mas, podem se tornar tóxicos quando estão presentes em excesso ou quando formam complexos orgânicos (NAVAS-PEREIRA, et. al. 1985).

O níquel, similarmente ao chumbo, é considerado altamente tóxico e bioacumulável. A $\mathrm{CL}_{50-96 \mathrm{~h}}$ para peixes varia de 5 a $100 \mathrm{mgL}^{-1}$ (NAVAS-PEREIRA, et. al. op. cit).

A prata pode causar argiria, de coloração azul-cinza de pele. Concentrações de 0,4 a $1 \mathrm{mgL}^{-1}$ ocasionam danos patológicos nos rins, fígado e baço de ratos. Em peixes de água doce, concentrações de $0,17 \mu \mathrm{gL}^{-1}$ podem causar efeitos toxicológicos. Baixas concentrações podem ser usadas como bactericidas para desinfecção de piscinas (APHA 1989).

O zinco é considerado como um dos elementos essenciais à saúde humana, mas também pode chegar a ser tóxico, dependendo da concentração. A bioacumulação do zinco em organismos aquáticos depende dos níveis tróficos; sendo maior nos organismos bentônicos do que nos peixes e maior em peixes onívoros do que em piscívoros. A temperatura influi na absorção do zinco, sendo maior em climas quentes (NAVAS-PEREIRA, et. al. op. cit.).

Este capítulo tem como objetivo analisar a situação da contaminação dos corpos da água da bacia hidrográfica do Alto Jacaré-Guaçu por metais traço, verificando se as concentrações, na água, estão de acordo com os Padrões de Qualidade Ambiental (PQA) da CONAMA 20/86. Além disso, procurar-se-á fornecer informações sobre as concentrações desses metais nos sedimentos e sua possível disponibilidade para a coluna da água e/ou biota. 


\subsection{MATERIAIS E MÉTODOS}

4.2.1 Análise de metais totais na água

A água para a análise de metais foi coletada superficialmente em frascos de polietileno, com capacidade para 500mL. Para sua preservação adicionou-se $\mathrm{HCl}$, sendo posteriormente refrigerada a $4^{\circ} \mathrm{C}$.

As amostras foram preservadas em isopor até sua chegada ao laboratório, onde foram congeladas em freezer, no máximo por 14 dias. Para análises dos metais na água utilizou-se uma alíquota de $400 \mathrm{~mL}$, a qual foi posteriormente digerida com $\mathrm{HNO}_{3}$ concentrado e reduzida até $50 \mathrm{~mL}$. O material digerido foi armazenado a $4^{\circ} \mathrm{C}$, até a determinação dos metais.

Os metais foram analisados em um espectrofotômetro de absorção atômica com chama, marca Hitachi, mod. Z8180, equipado com polarizador Zeeman.

\subsubsection{Análise de metais pesados no sedimento}

\subsubsection{Biodisponíveis}

Para as análises dos metais potencialmente biodisponíveis pesou-se cerca de $1,0 \mathrm{~g}$ de sedimento seco $\left(120^{\circ} \mathrm{C}, 12\right.$ horas) que, posteriormente, foi pulverizado no interior de um erlenmeyer. Em seguida, adicionou-se $25 \mathrm{~mL}$ de $\mathrm{HCl} 0,1 \mathrm{molL}^{-1}$ e a mistura foi submetida à agitação em um agitador horizontal por 2 horas. Após esta operação, a suspensão foi filtrada e o filtrado lido por espectrofotometria de absorção atômica por chama (MOZETO, 1999).

\subsubsection{Totais}

$\mathrm{Na}$ amostragem do período de seca (agosto/99) foi analisada, além dos metais potencialmente biodisponiveis, a concentração de metais totais nas amostras do sedimento e, deste modo, foi possivel 
conhecer o grau de disponibilidade de cada metal com relação à concentração total no sedimento.

Para as análises dos metais totais, o sedimento, após totalmente seco, foi triturado até pulverização. $O$ sedimento pulverizado foi então transferido para potes plásticos até a pesagem. Para a análise de metais totais, $1,0 \mathrm{~g}$ de sedimento foi pesado e colocado em tubos do aparelho digestor aquecedor, sendo adicionada uma solução concentrada de $10 \mathrm{~mL}$ de $\mathrm{HNO}_{3}$ e $5 \mathrm{~mL}$ de $\mathrm{HClO}_{4}$. Após um tempo de 2 horas de aquecimento numa temperatura de $150^{\circ} \mathrm{C}$, retirou-se o tubo do aparelho digestor e, após um breve resfriamento, adicionou-se $5 \mathrm{~mL}$ de $\mathrm{H}_{2} \mathrm{O}_{2}$. A digestão foi feita até que o conteúdo do tubo deixasse de expelir gases escuros e o sedimento perdesse a cor, adquirindo uma tonalidade clara.

Feita a digestão, esperou-se o material esfriar, filtrou-se com papel de filtro em funil de vidro e transferiu-se de 50mL, completando-se o volume. Posteriormente, o conteúdo foi colocado em frascos de polietileno e tampados. O material foi analisado no espectrômetro de absorção atômica. Quando a solução apresentou-se muito concentrada, utilizou-se água bidestilada (milli Q) para fazer as diluições necessárias. Após a análise, fizeram-se as conversões para a determinação dos metais na amostra original de sedimento.

\subsection{RESULTADOS}

4.3.1 Concentração de metais na água

Os resultados referentes às concentrações de metais na água, nos períodos amostrados (chuvas e estiagem), são apresentados na tabela I (anexo).

Dos metais analisados chumbo, cobalto, cobre e prata, foram detectados só no período das chuvas. O chumbo foi detectado com valores que variaram entre $0,001 \mathrm{mgL}^{-1}$ e $0,005 \mathrm{mgL}^{-1}$, Figura 1 . O 
cobalto foi detectado sem grandes variações em suas concentrações com valores de $0,005 \mathrm{mgL}^{-1}$ e $0,006 \mathrm{mgL}^{-1}$, Figura 2. O cobre foi detectado com valores que oscilaram entre $0,033 \mathrm{mgL}^{-1}$ e $0,044 \mathrm{mgL}^{-1}$, Figura 3. A prata foi detectada com valores de $0,008 \mathrm{mgL}^{-1}$ nas nascentes do Ribeirão do Feijão e do Córrego São José (F1 e F3) e 0,005 $\mathrm{mgL}^{-1}$ nos outros pontos de coleta (M1, M2, M5, F2, F4 e F5), figura 4.

No período das chuvas o ferro apresentou valores desde 1,319 $\mathrm{mgL}^{-1}$ no ponto M1 até 5,319mgL-1 no ponto M5. Já no período da seca apresentou as maiores variações em suas concentrações na bacia do Monjolinho, com valores desde $0,060 \mathrm{mgL}^{-1}$ no ponto M1 até 6,600mgL-1 no ponto M5, Figura 5.

O manganês no período das chuvas foi detectado em concentrações de $0,008 \mathrm{mgL}^{-1}$ até $0,063 \mathrm{mgL}^{-1}$. Já no período de estiagem as concentrações de manganês variaram de $0,110 \mathrm{mgL}^{-1}$ (M3), 0,120 $\mathrm{mgL}^{-1}$ (M4) e 0,230mgL-1 (M5), até não ser detectado em F4, F5, J1, J2, J3 e J4 (Figura 6).

O zinco, no período das chuvas, foi detectado em todos os pontos analisados, com valores que oscilaram entre $0,001 \mathrm{mgL}^{-1} \mathrm{e}$ $0,005 \mathrm{mgL}^{-1}$, concentrações abaixo do PGA $\left(0,180 \mathrm{mgL}^{-1}\right)$. No período de estiagem, o zinco só foi detectado nos pontos após da área urbana, com valores de 0,140mgL-1 (M3), 0,150mgL-1 (M4) e 0,260mgL-1 (M5), Figura 7. 

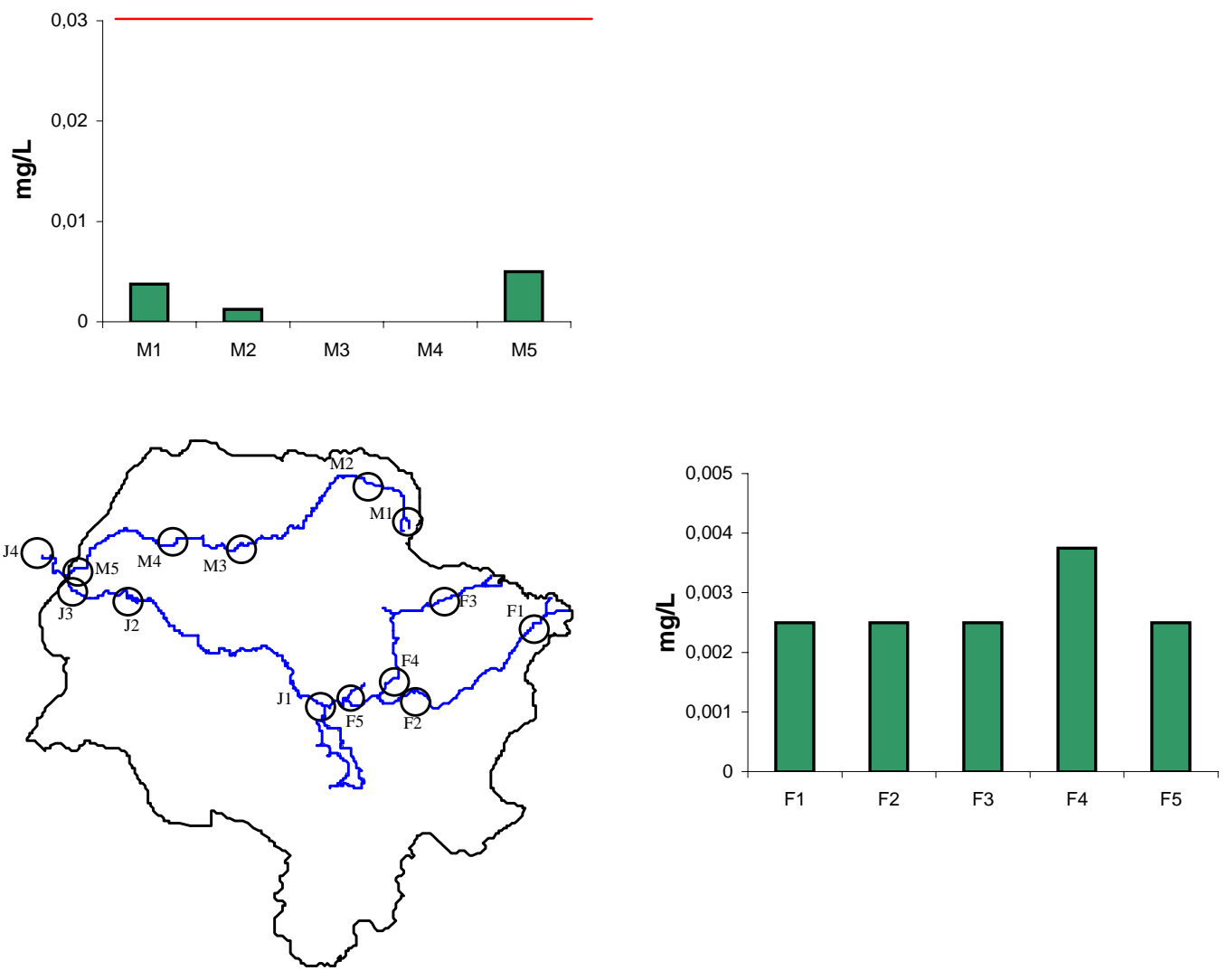

CONAMA $20 / 86=(0,030 \mathrm{mg} / \mathrm{I})$

Figura 1. Concentração de chumb(mg/L), na bacia hidrográfica do Alto Jacaré-Guaçu, no período das chuvas. 

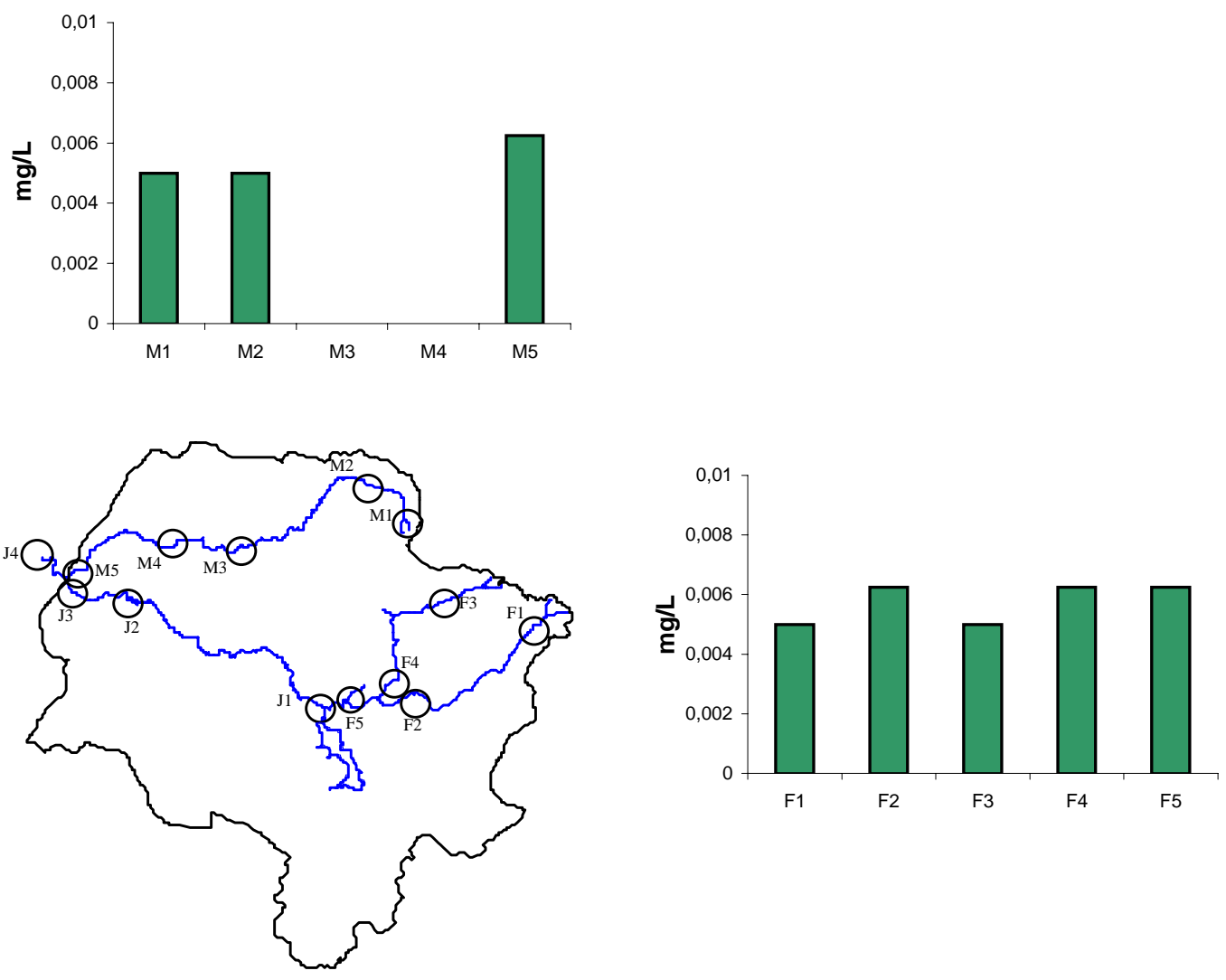

CONAMA $20 / 86=(0,20 \mathrm{mg} / \mathrm{L})$

Figura 2. Concentração de cobalt(mg/L), na bacia hidrográfica do Alto Jacaré-Guaçu, no período das chuvas. 

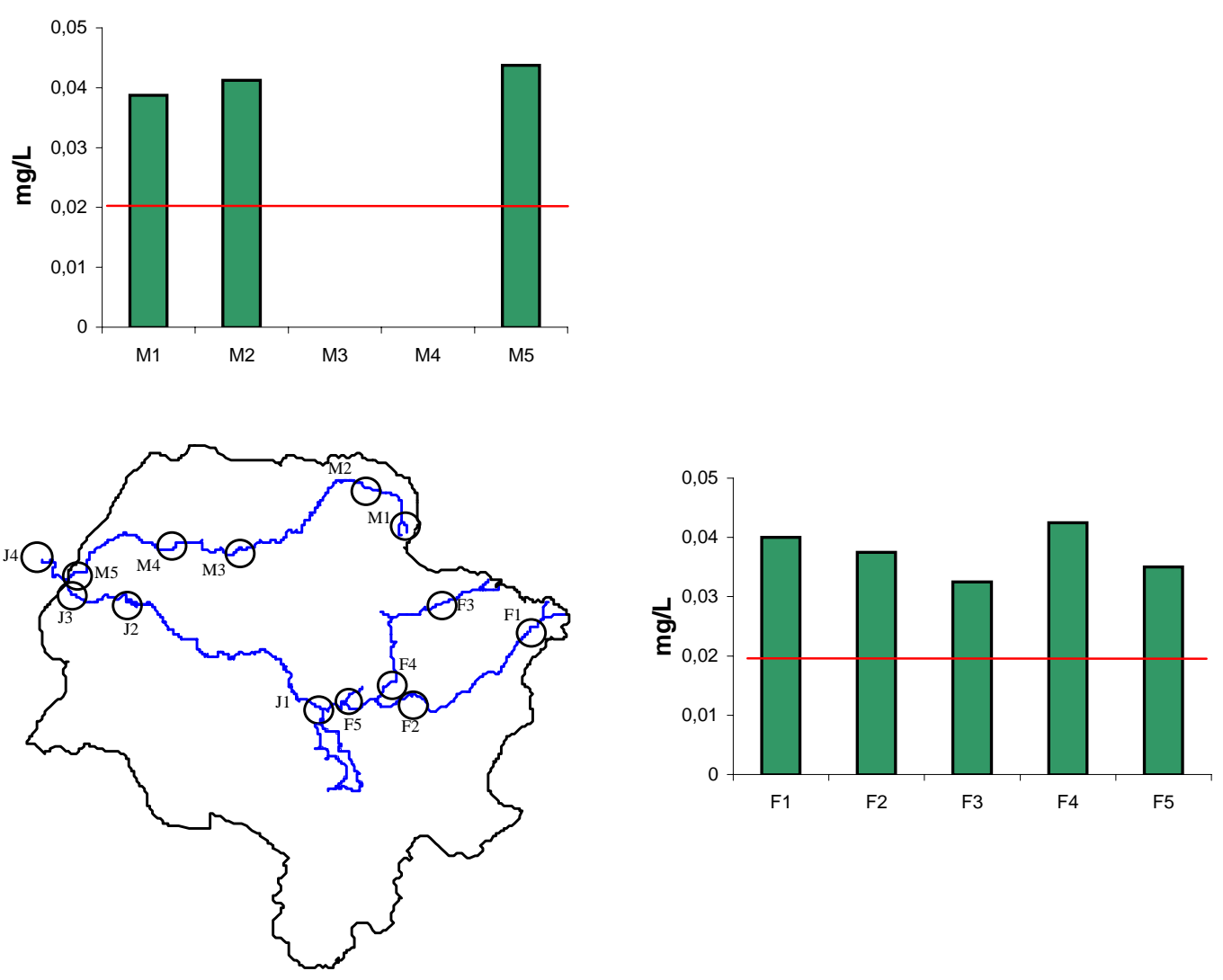

CONAMA $20 / 86=(0,020 \mathrm{mg} / \mathrm{I})$

Figura 3. Concentração de cobr(mg/L), na bacia hidrográfica do Alto Jacaré-Guaçu, no período das chuvas. 

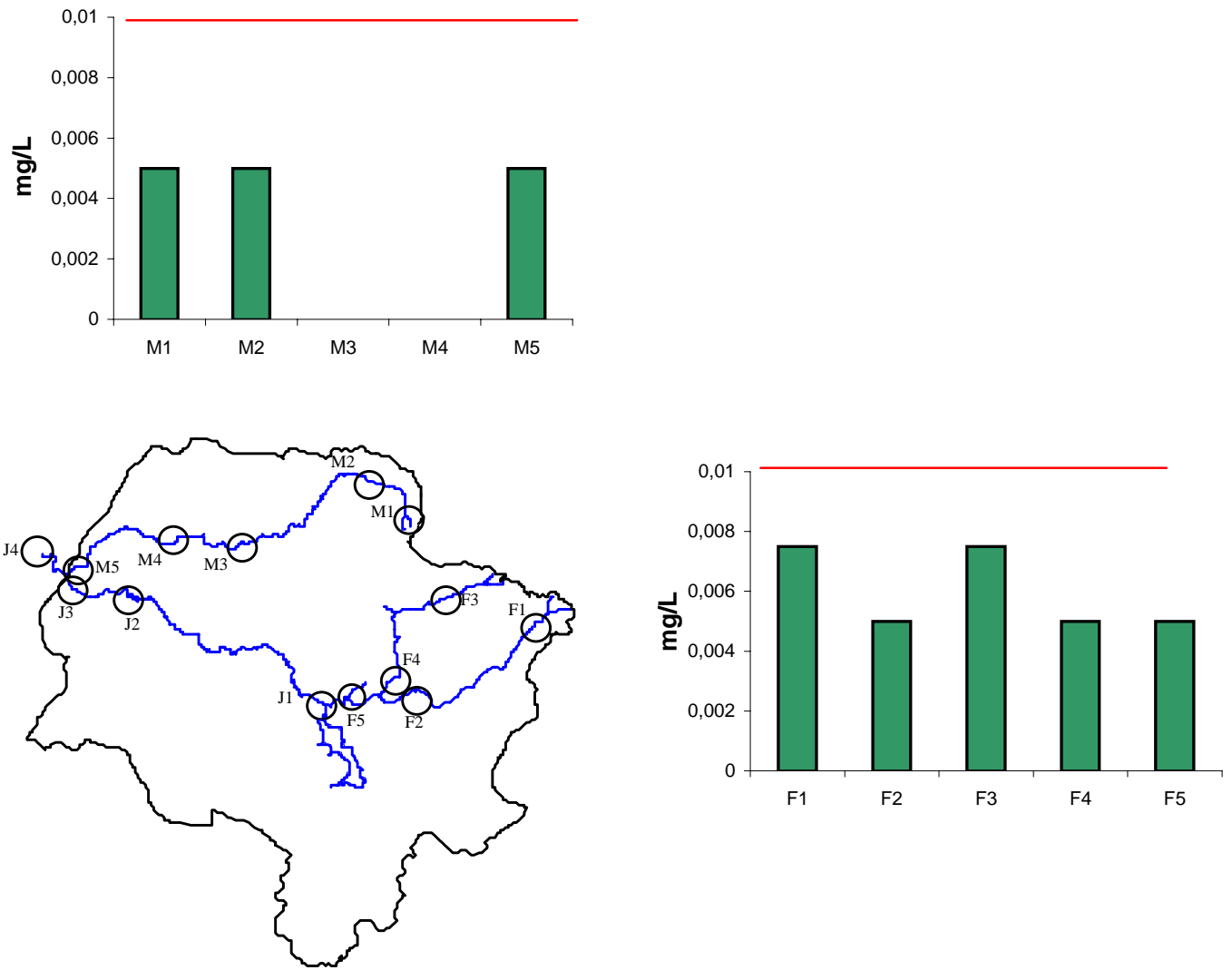

CONAMA $20 / 86=(0,010 \mathrm{mg} / \mathrm{I})$

Figura 4. Concentração de prat(̣mg/L), na bacia hidrográfica do Alto Jacaré-Guaçu, no período das chuvas. 

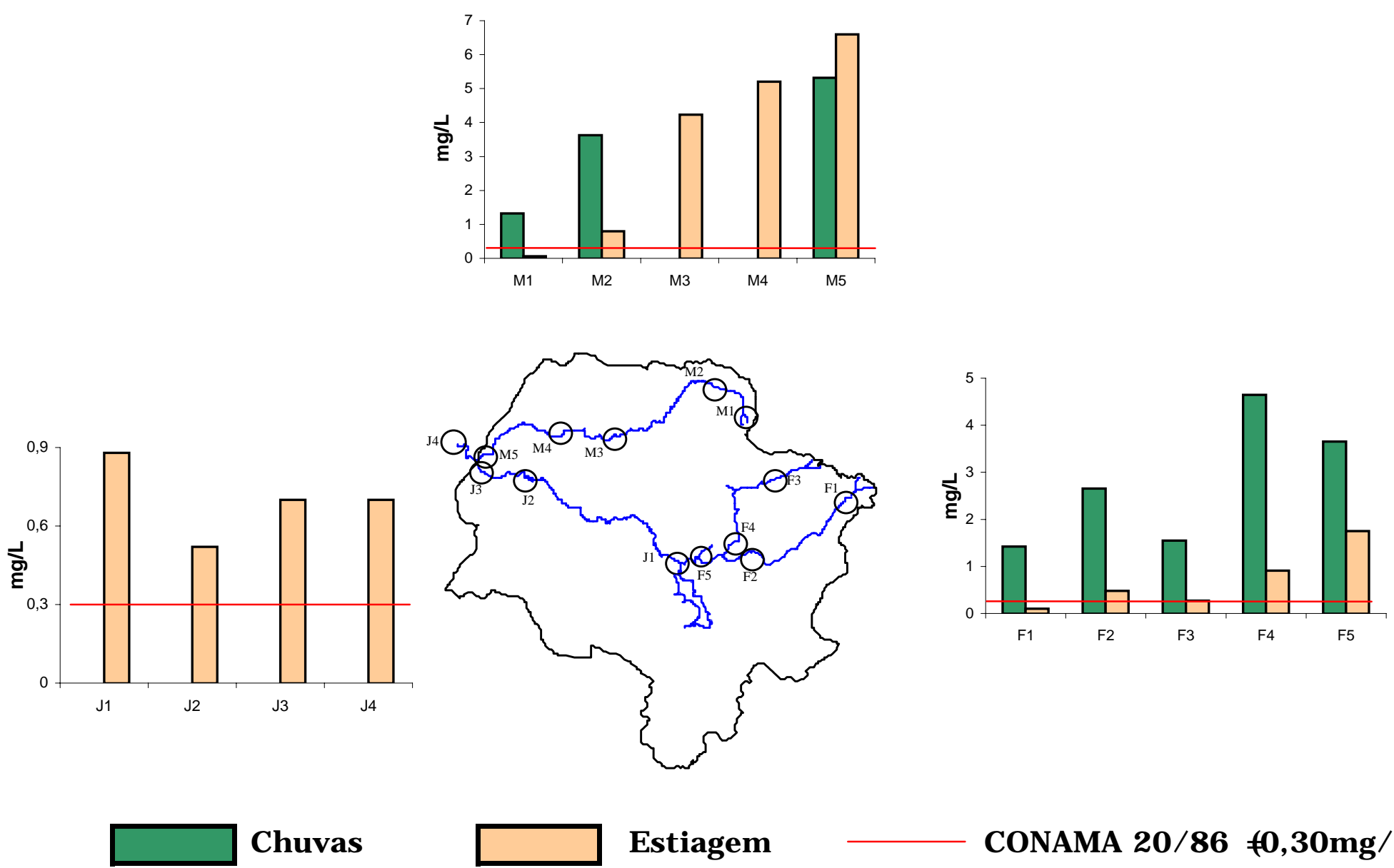

CONAMA 20/86 $\neq 0,30 \mathrm{mg} / \mathrm{L}$

Figura 5. Concentração de ferr(ong/L), na bacia hidrográfica do Alto Jacaré-Guaçu, nos período de estudo. 

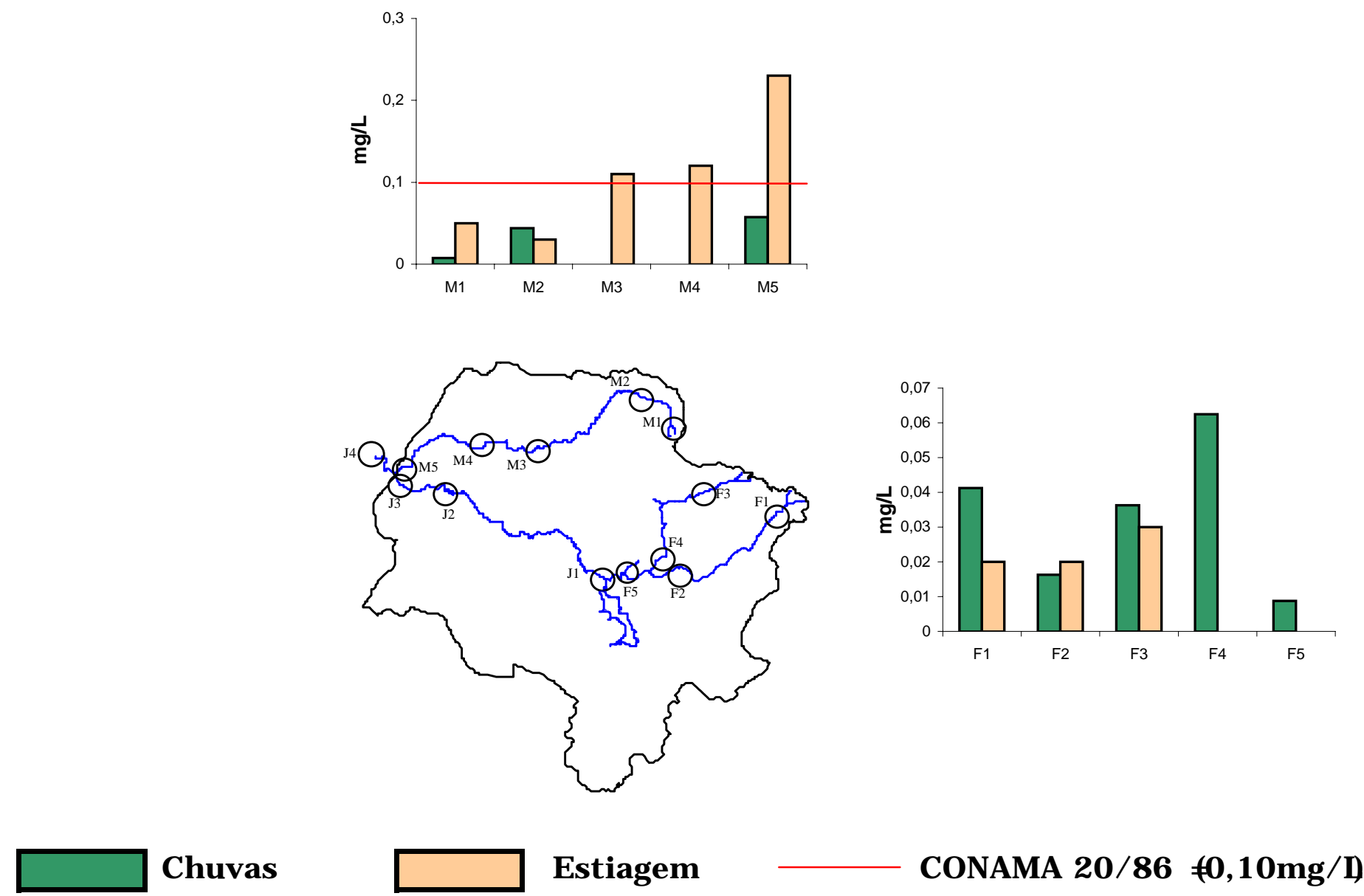

Figura 6. Concentração de manganê(\$ng/L), na bacia hidrográfica do Alto Jacaré-Guaçu, nos períodos de estudo. 

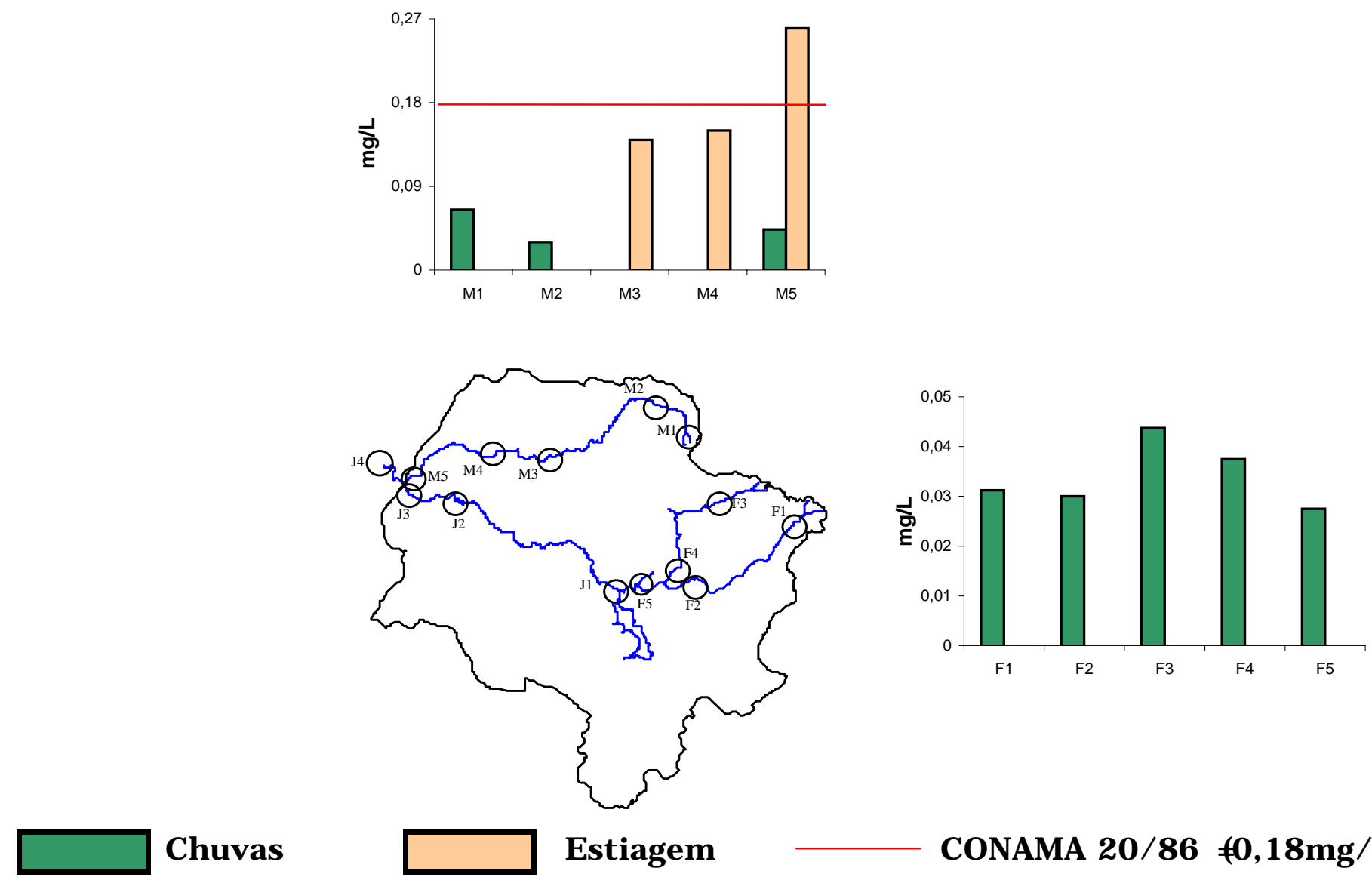

CONAMA $20 / 86 \neq 0,18 \mathrm{mg} / \mathrm{L}$

Figura 7. Concentração de zinc(mg/L), na bacia hidrográfica do Alto Jacaré-Guaçu, nos períodos de estudo. 


\subsubsection{Análises no Sedimento}

\subsubsection{Biodisponíveis}

Foram detectadas concentrações dos seguintes metais biodisponiveis: chumbo, cobalto, cobre, ferro, manganês prata e zinco. As concentrações dos metais são apresentadas na tabela II (anexo).

Em relação ao chumbo potencialmente biodisponível, este não apresentou um padrão nas concentrações, com um valor mínimo de 0,19 mgkg $^{-1}$ no ponto $F 3$, no período das chuvas e um máximo, de 2,23mgkg-1 no ponto M4, no período de estiagem (Figura 8).

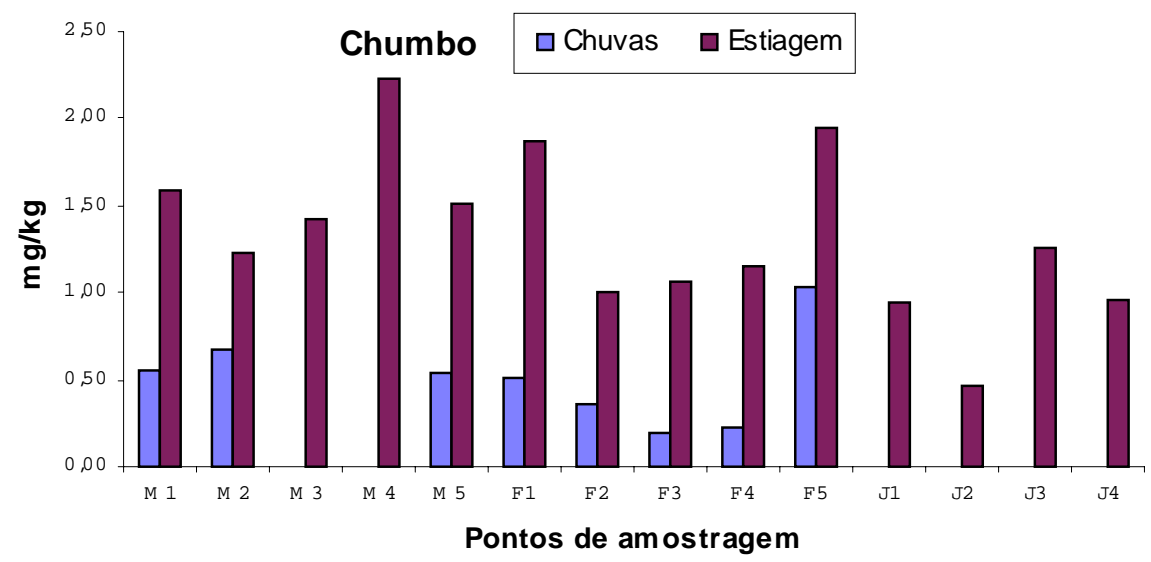

Figura 8. Concentração de chumbo potencialmente biodisponivel na bacia hidrográfica do Alto Jacaré-Guaçu.

O cobalto no período das chuvas foi detectado em todos os pontos de amostragem, com maior valor no ponto F5 (7,41 mgkg-1). Já no período de estiagem foi detectado nos pontos M3, M4 e F5, onde novamente, apresentou a máxima concentração, com um valor de 10,93mgkg-1 (F5), conforme apresentado na Figura 9. 


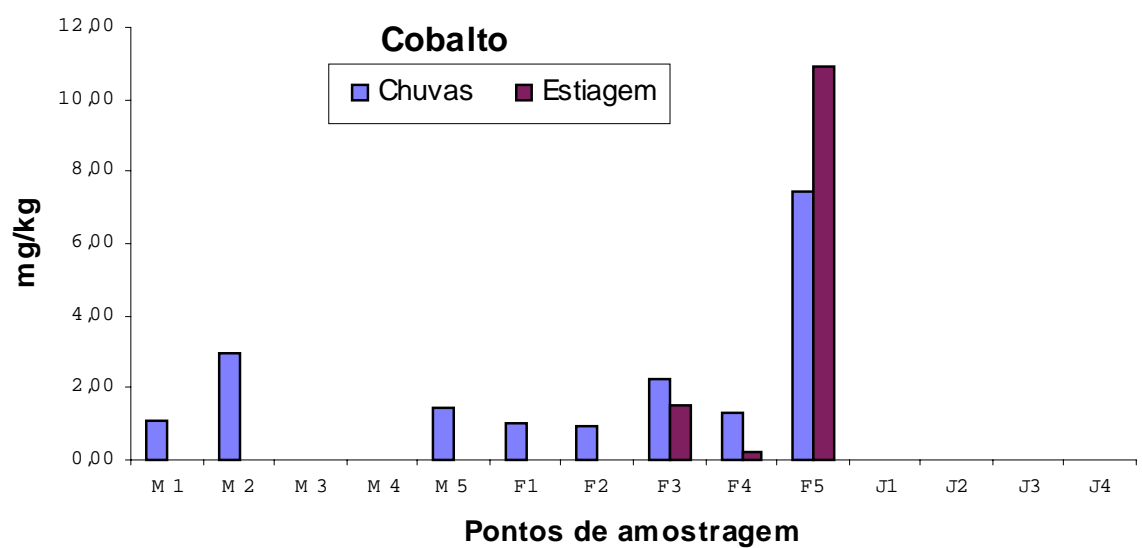

Figura 9. Concentração de cobalto potencialmente biodisponivel na bacia hidrográfica do Alto Jacaré-Guaçu.

O cobre foi detectado em todos os pontos de amostragem, apresentando seus maiores valores nos pontos de captação de água, M2 e F5, no período das chuvas, com valores de 6,33mgkg-1 e $5,86 \mathrm{mgkg}^{-1}$, respectivamente. Já no período de estiagem os maiores valores foram detectados nos pontos M4 (10,48mgkg-1) e M5 $\left(9,87 \mathrm{mgkg}^{-1}\right)$, conforme apresentado na Figura 10.

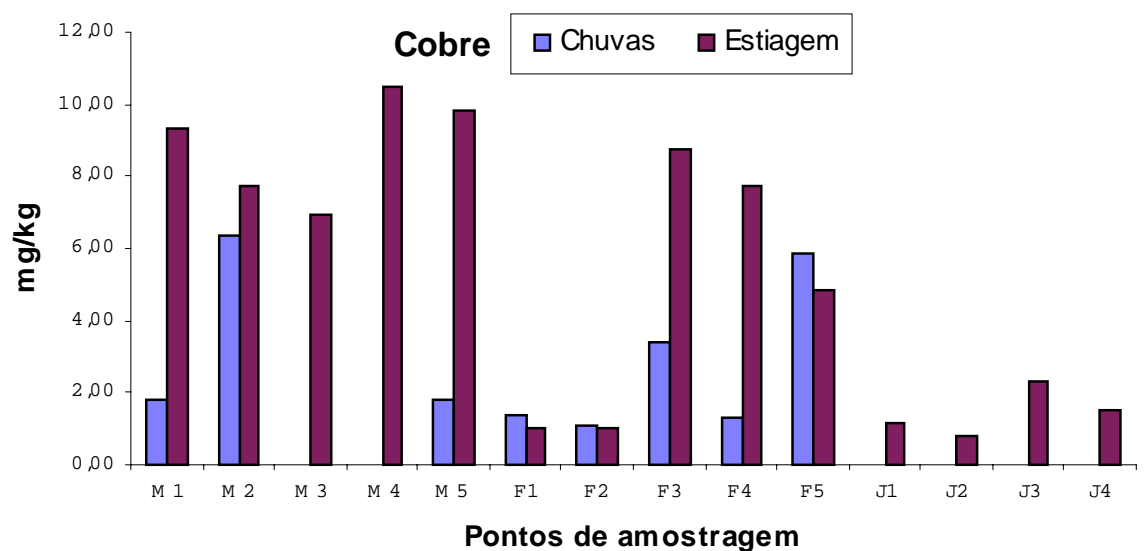

Figura 10. Concentração de cobre potencialmente biodisponivel na bacia hidrográfica do Alto Jacaré-Guaçu. 
O cromo foi detectado, no período de estiagem, apenas nos pontos M2 e F5 (Figura 11).

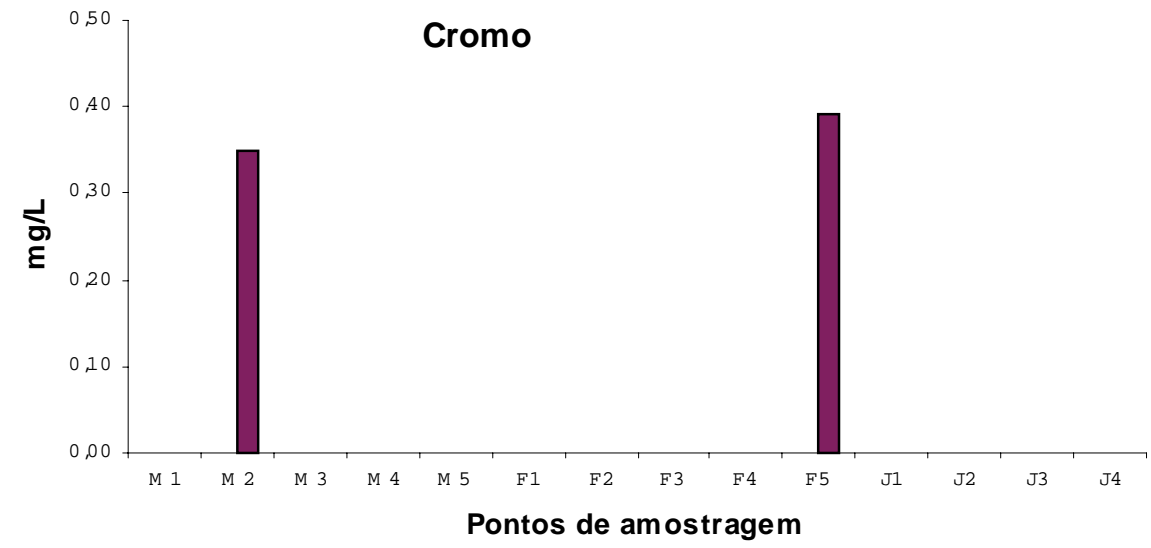

Figura 11. Concentração de cromo potencialmente biodisponível na bacia hidrográfica do Alto Jacaré-Guaçu.

O ferro teve suas maiores concentrações no período de estiagem, a exceção do ponto M2 onde a concentração do período da chuva foi um pouco maior, com 936mgkg-1 e 845mgkg-1 respectivamente (Figura 12).

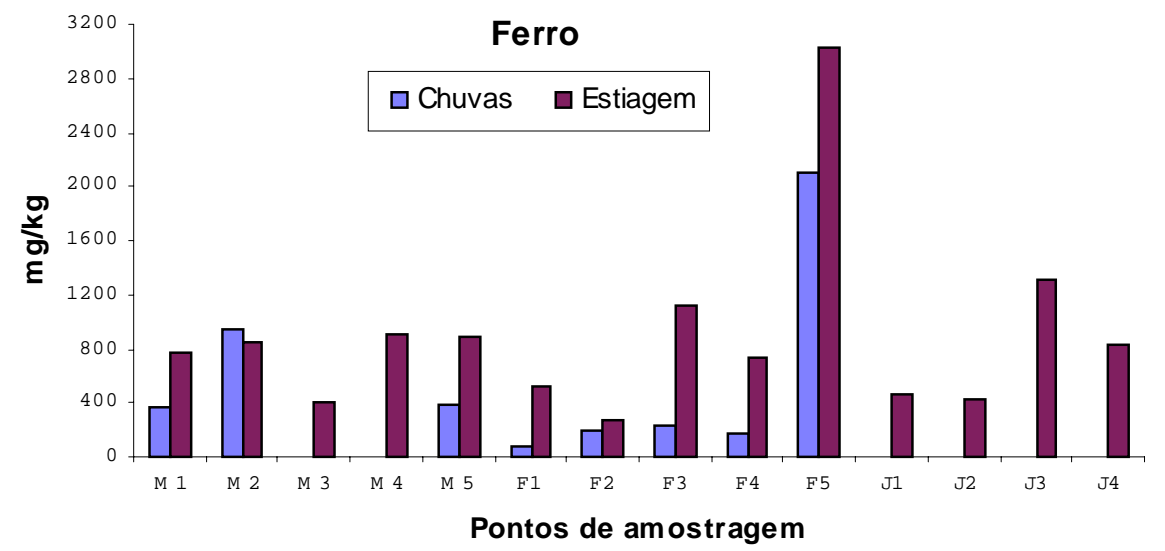

Figura 12. Concentração de ferro potencialmente biodisponível na bacia hidrográfica do Alto Jacaré-Guaçu. 
O manganês teve um comportamento similar ao do ferro com suas maiores concentrações no período de estiagem, a exceção dos pontos M2 e F5, onde as concentrações do período das chuvas foram maiores (Figura 13).

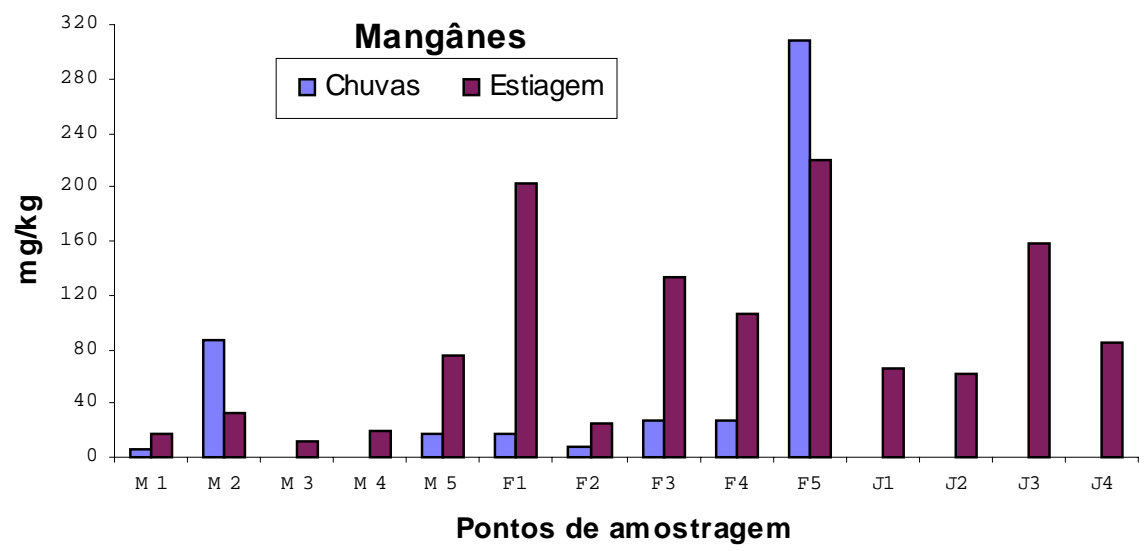

Figura 13. Concentração de manganês potencialmente biodisponível na bacia hidrográfica do Alto Jacaré-Guaçu.

O níquel, a exemplo do cromo, só foi detectado no período de estiagem, com um valor mínimo de $0,58 \mathrm{mgkg}^{-1}$, no ponto $\mathrm{J} 2$, e um máximo de 2,55mgkg-1, no ponto F3 (Figura 14).

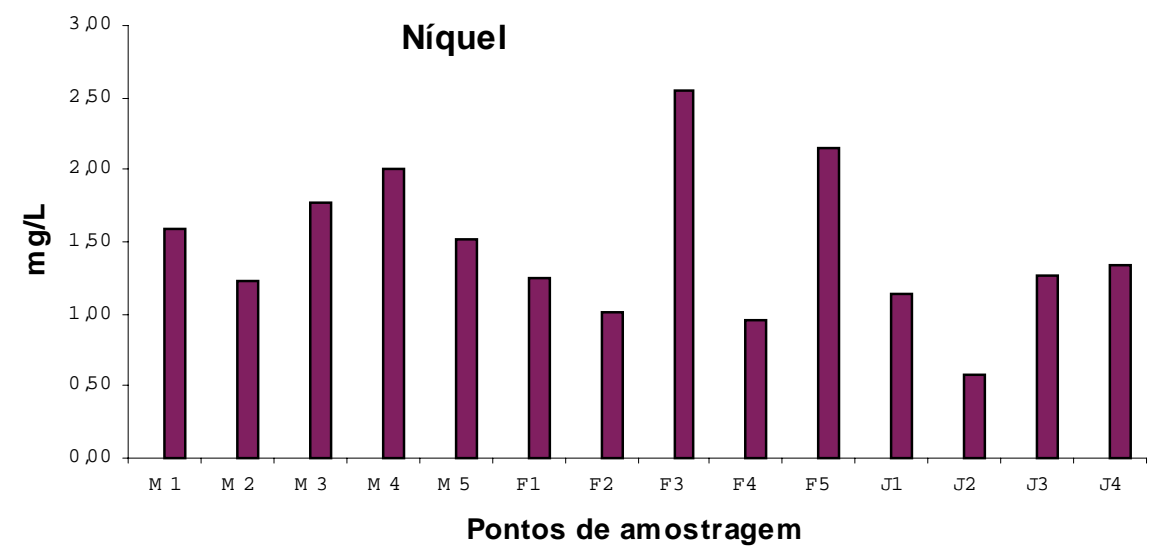

Figura 14. Concentração de níquel potencialmente biodisponível na bacia hidrográfica do Alto Jacaré-Guaçu. 
As concentrações de prata potencialmente biodisponíveis não apresentaram grandes variações, com valores entre $0,58 \mathrm{mgkg}^{-1}$ (no ponto J2) e $1,14 \mathrm{mgkg}^{-1}$ (no ponto M1), ambos na estiagem (figura 15).

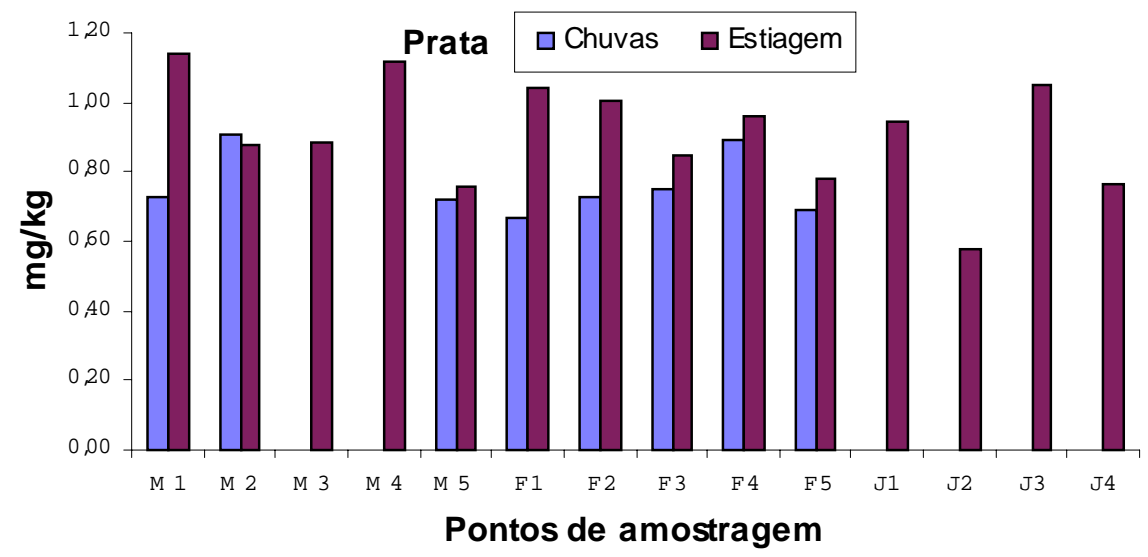

Figura 15. Concentração de prata potencialmente biodisponível na bacia hidrográfica do Alto Jacaré-Guaçu.

O zinco, da mesma forma que o cobre, apresentou suas maiores concentrações nas captações (M2 e F5), com um valor máximo de 24,89mgkg-1 (M2) no período das chuvas. Já na estiagem os valores estiveram abaixo de 9,00 $\mathrm{mgkg}^{-1}$, (Figura 16).

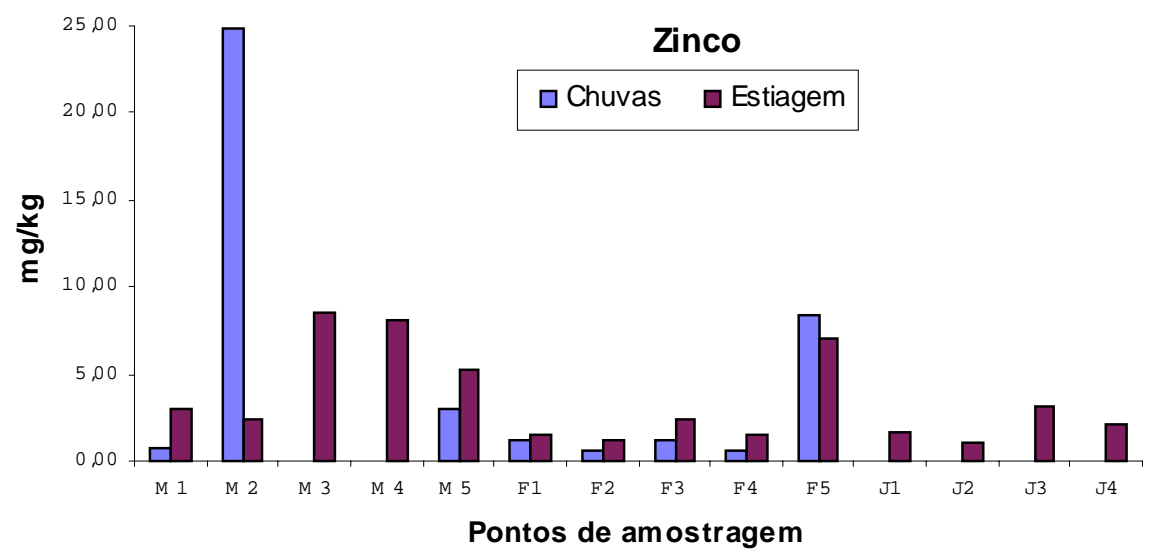

Figura 16. Concentração de zinco potencialmente biodisponível na bacia hidrográfica do Alto Jacaré-Guaçu. 


\subsubsection{Totais}

$\mathrm{Na}$ coleta de agosto, além da análise de metais potencialmente biodisponiveis, foi realizada a análise da concentração total para, desta forma, se conhecer a fração do conteúdo total com potencial para ser incorporado pelos organismos (Tabela III).

Tabela III. Porcentagem referente à fração do conteúdo total de metais do sedimento com potencial para ser incorporado pelos organismos e ordem decrescente de biodisponibilidade do metal, no período de estiagem de 1999, na bacia hidrográfica do Alto Jacaré-Guaçu.

\begin{tabular}{ccccccc}
\hline Pontos & $\mathrm{Ag}$ & $\mathrm{Cu}$ & $\mathrm{Ni}$ & $\mathrm{Pb}$ & $\mathrm{Zn}$ & Biodisponibilidade \\
\hline M1 & 54 & 13 & 41 & 76 & 10 & $\mathrm{~Pb}, \mathrm{Ag}, \mathrm{Ni}, \mathrm{Cu}, \mathrm{Zn}$ \\
M2 & 40 & 11 & 37 & 37 & 12 & $\mathrm{Ag}, \mathrm{Pb}, \mathrm{Ni}, \mathrm{Zn}, \mathrm{Cu}$, \\
M3 & 41 & 10 & 22 & 40 & 11 & $\mathrm{Ag}, \mathrm{Pb}, \mathrm{Ni}, \mathrm{Zn}, \mathrm{Cu}$ \\
M4 & 47 & 14 & 12 & 51 & 15 & $\mathrm{~Pb}, \mathrm{Ag}, \mathrm{Zn}, \mathrm{Cu}, \mathrm{Ni}$ \\
M5 & 42 & 20 & 53 & 84 & 27 & $\mathrm{~Pb}, \mathrm{Ni}, \mathrm{Ag}, \mathrm{Zn}, \mathrm{Cu}$ \\
F1 & 65 & 7 & 39 & 83 & 9 & $\mathrm{Ag}, \mathrm{Pb}, \mathrm{Ni}, \mathrm{Zn}, \mathrm{Cu}$, \\
F2 & 53 & 4 & 89 & 53 & 5 & $\mathrm{Ni}, \mathrm{Pb}=\mathrm{Ag}, \mathrm{Zn}, \mathrm{Cu}$ \\
F3 & 48 & 15 & 54 & 40 & 9 & $\mathrm{Ni}, \mathrm{Ag}, \mathrm{Pb}, \mathrm{Cu}, \mathrm{Zn}$ \\
F4 & 47 & 11 & 19 & 37 & 8 & $\mathrm{Ag}, \mathrm{Pb}, \mathrm{Ni}, \mathrm{Cu}, \mathrm{Zn}$ \\
F5 & 40 & 20 & 26 & 40 & - & $\mathrm{Pb}=\mathrm{Ag}, \mathrm{Ni}, \mathrm{Cu}, \mathrm{Zn}$ \\
J1 & 48 & 5 & 41 & 48 & 5 & $\mathrm{~Pb}=\mathrm{Ag}, \mathrm{Ni}, \mathrm{Zn}=\mathrm{Cu}$ \\
J2 & 33 & 4 & 33 & 33 & 7 & $\mathrm{~Pb}=\mathrm{Ag}=\mathrm{Ni}, \mathrm{Zn}, \mathrm{Cu}$ \\
J3 & 62 & 11 & 25 & 62 & 23 & $\mathrm{~Pb}, \mathrm{Ag}, \mathrm{Ni}, \mathrm{Zn}, \mathrm{Cu}$ \\
J4 & 39 & 4 & 57 & 49 & 13 & $\mathrm{Ni}, \mathrm{Pb}, \mathrm{Ag}, \mathrm{Zn}, \mathrm{Cu}$ \\
\hline
\end{tabular}

Em geral, à porcentagem de biodisponibilidade para a prata foi alta, em relação à concentração total, sendo que o maior valor foi obtido para o ponto F1 (65\%) e a menor para o ponto J2 (33\%).

A porcentagem de biodisponibilidade dos valores detectados de cobre, em geral, foram baixos, com valores máximos de 20\%, nos pontos M5 e F5.

$\mathrm{O}$ níquel variou muito com respeito à porcentagem de disponibilidade, com valores entre $12 \%$ e $89 \%$, para os pontos M4 e F2, respectivamente. 
A biodisponibilidade para o chumbo, não teve uma tendência definida, com uma faixa de valores entre 33\% (J2) e 84\% (M5).

Os valores de biodisponibilidade das concentrações de zinco apresentaram-se, em geral, baixos, com valores máximos próximos a 30\% (no ponto M5).

\subsection{DISCUSSÃO}

Os metais são considerados como um dos contaminantes mais comuns nas águas e sua origem podem ser naturais (ligada à composição do solo) ou antrópica (proveniente de lançamentos de efluentes industriais e domésticos ou lixiviação de produtos agrícolas e de resíduos sólidos).

Segundo FÖRSTNER (1983), é difícil estabelecer valores médios globais de metais nos corpos de água. Isto é devido, em primeiro lugar, à variedade das formações de rochas que conformam os leitos dos corpos de água e, em segundo lugar, as flutuações no transporte destes elementos na água, principalmente nos ambientes lóticos. Os metais mais comumente encontrados em concentrações superiores às naturais nos ecossistemas aquáticos, provenientes da ação antrópica, são o ferro, o manganês, o cobre, o chumbo, o zinco, o cromo, o níquel, o cádmio, o alumínio e, dependendo das atividades desenvolvidas na região, o mercúrio (BARRETTO, 1999).

Os valores das concentrações dos metais detectados foram comparados com os PQA da resolução Conama 20/86 (CETESB, 1986) para corpos de água classe 2 (classe na qual estão enquadrados os principais rios da bacia em estudo) e com dados da literatura.

Com base na Resolução CONAMA 20/86 o cobre e o ferro no período das chuvas e o ferro e o manganês nos pontos após a área urbana (M3, M4 e M5) e o zinco (M5), no período de estiagem estiveram acima dos PQA. 
A contaminação por cobre pode vir a partir de esgotos domésticos e industriais e lixiviação de produtos agrícolas (chuvas). As altas concentrações de ferro devem-se provavelmente à composição do solo (BARRETTO, op. cit.) e aos efluentes industriais, já que foram os pontos após a área urbana os que apresentaram as maiores concentrações deste metal. As concentrações de manganês apresentaram um padrão semelhante às concentrações do ferro, com os maiores níveis após a área urbana, provavelmente devido a que seu uso está associada a utilização do ferro (BARRETTO, 1999).

O fato de que a concentração de zinco, no ponto M5, no período de estiagem, está acima do Padrão da CONAMA 20 pode ser devido ao costume de queimadas nas plantações de cana-de-açúcar, a montante do ponto de coleta (M5), as quais são muito comuns nessa época do ano (ZIOLLI, 1995).

Comparando as concentrações de metais aqui obtidas com estudos anteriores de FISCHER (1995), na sub-bacia do ribeirão do Feijão, no período de estiagem, verificou-se zinco em concentrações

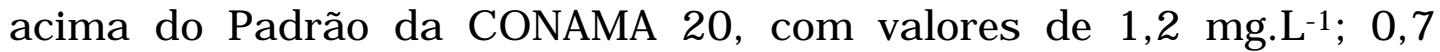
mg.L. $\mathrm{L}^{-1}$, 2,4 mg. $\mathrm{L}^{-1}$ e 1,2 mg.L-1; nos pontos F2, F3, F4 e F5 respectivamente. No presente estudo nessa sub-bacia não foi detectada a presença desse metal, mas cabe ressaltar que nesse período ainda estava funcionando o lixão de São Carlos, a montante do ponto $\mathrm{F} 4$, o qual foi o que apresentou a maior concentração $(2,4$ mgL-1). BARRETO (op. cit.), para a sub-bacia do Monjolinho, detectou $\mathrm{Cu}, \mathrm{Fe}, \mathrm{Mn}$ e $\mathrm{Zn}$ em concentrações similares às do presente estudo.

Em termos gerais, no período das chuvas foi onde se detectou o maior número de ocorrências de metais nos pontos de coleta devido, provavelmente, à lixiviação do solo provocada pelas chuvas. Já no período de estiagem as maiores concentrações dos metais detectados (zinco, ferro e manganês) foram encontradas nos pontos após a área urbana da cidade de São Carlos, evidenciando, como fonte principal, os esgotos domésticos e industriais. 
Os sedimentos no ecossistema aquático refletem a qualidade da água do sistema, suas variações físicas no decorrer do tempo e os fatores hidrodinâmicos. Nos casos em que somente a análise da água é insuficiente, os sedimentos têm papel importante na identificação, no monitoramento e no controle das fontes poluidoras. Isto é de grande importância em termos de metais, pois uma vez despejados em águas superficiais, eles tendem a se ligar ao material particulado, não permanecendo na forma solúvel na coluna da água (TINSLEY, 1979). No sedimento, por processos abióticos ou bióticos, os metais podem retornar, novamente, à coluna da água e incorporar-se na biota presente.

O conteúdo total de metais em sedimentos corresponde ao somatório das quatro principais formas de ocorrência desses elementos nos sedimentos, que são, segundo ROSE et. al. (1979) as seguintes: (1) absorvidos às superfícies por atração iônica; (2) coprecipitados em óxidos, hidróxidos e carbonatos; (3) incorporados à matéria orgânica e sulfetos e (4) como parte integrante da estrutura cristalina dos minerais.

Segundo DE PAULA (1999), para avaliar o risco de contaminação da biota por metais é importante se conhecer a fração móvel ou disponível desses elementos, que é, basicamente, composta pelos metais absorvidos às superfícies por atração iônica, mais parte do conteúdo metálico co-precipitado em óxidos, hidróxidos e carbonatos e parte do incorporado à matéria orgânica e sulfetos. Metais ligados a óxidos, hidróxidos e materiais orgânicos refratários ou formadores da estrutura cristalina dos minerais estão presos por ligações covalentes extremamente fortes e não são rompidas pelas atividades metabólicas de incorporação de elementos químicos, tanto por plantas como por animais.

Uma análise comparativa dos resultados obtidos no presente trabalho com os reportados na literatura (LIMA, 1990; BARRETTO, 
1999; SANTOS, 1999; SILVERIO 2000 e TONISSI, 1999) é apresentada na Tabela IV.

Tabela IV. Concentração de metais biodisponiveis (em mgkg-1 de sedimento seco) em vários trabalhos na literatura para intercomparação com os resultados encontrados na bacia do Alto Jacaré-Guaçu.

\begin{tabular}{|c|c|c|c|c|c|c|}
\hline Corpo de água & $\mathrm{Cd}$ & $\mathrm{Cr}$ & $\mathrm{Cu}$ & $\mathrm{Ni}$ & $\mathrm{Pb}$ & $\mathrm{Zn}$ \\
\hline Rio Monjolinho a & $\mathrm{Nd}$ & 1,16 & 2,86 & 1,23 & 1,43 & 9,00 \\
\hline Córrego do Cafundó b & 0,08 & nd & 4,66 & 0,14 & 1,22 & 6,15 \\
\hline Córrego Boa Sorte ${ }^{b}$ & $\mathrm{Nd}$ & 0,44 & 2,20 & nd & 0,15 & 3,00 \\
\hline Córrego Jataí b & 0,05 & 1,06 & 6,65 & 1,03 & 1,31 & 7,15 \\
\hline Rio Anhumas ${ }^{c}$ & 0,41 & 0,93 & 16,78 & 5,59 & 4,23 & $*$ \\
\hline Represa Billings d & 1,7 & 25 & 62 & $*$ & 32 & 444 \\
\hline Represa de Barra Bonita d & $\mathrm{Nd}$ & 2,40 & 5,20 & 5,80 & 4,50 & 10,7 \\
\hline Represa de Salto Grande ${ }^{\mathrm{e}}$ & 0,08 & 7,41 & 24,5 & 9,08 & 9,77 & 78,27 \\
\hline Alto Jacaré-Guaçu ${ }^{\mathrm{f}}$ & $\mathrm{Nd}$ & nd & 5,25 & 1,45 & 1,33 & 3,49 \\
\hline Rio Monjolinho $\mathrm{f}$ & $\mathrm{Nd}$ & nd & 8,86 & 1,62 & 1,60 & 5,46 \\
\hline
\end{tabular}

Comparando as concentrações de metais potencialmente biodisponíveis com os determinados por BARRETTO (1999) para o rio Monjolinho, LIMA (1990) em córregos da estação Ecológica de Jataí e SANTOS (1999) no rio Anhumas (Américo Brasiliense-SP), pode-se observar que os valores estão, em geral, na mesma ordem de grandeza. Já a comparação com as concentrações detectadas nas represas de Billings e Barra Bonita (SILVEIRO, 2000) e Salto Grande (TONISSI, 1999), ambientes sabidamente impactados 
antropicamente, os valores são até mais de 100 vezes superiores, como é o caso de zinco.

Um aspecto importante que se deve observar quanto a esta fração do sedimento, que reflete a biodisponibilidade potencial desses metais para a coluna da água, é a porcentagem que eles representam para as concentrações totais. Em termos gerais, na bacia do Alto Jacaré-Guaçu, a porcentagem da fração biodisponivel com respeito à concentração total foi alta, principalmente para chumbo (52\%) e prata (47\%), metais altamente tóxicos (FÖRSTNER \& WITTMANN, 1983), o que sugere uma possibilidade significativa de transferência desses metais para a biota aquática, representando um possível risco de toxicidade e/ou bioacumulação para a biota presente. 


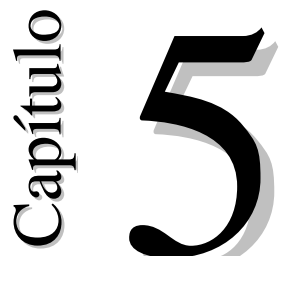

\author{
ANÁLISE DE COMPOSTOS \\ ORGANOCLORADOS (PESTICIDAS E \\ BIFENILAS POLICLORADAS) NA BACIA \\ DO ALTO JACARÉ-GUAÇU, SÃO PAULO
}

\title{
5.1 INTRODUÇÃO
}

Milhares de compostos orgânicos entram nos corpos de água como resultado das atividades humanas. Esses compostos têm significativamente diferentes propriedades físicas, químicas e toxicológicas. Monitorar cada composto individual não é fácil. Porém, é possível selecionar a prioridade dos poluentes orgânicos baseados em sua prevalência, toxicidade e outras propriedades. Óleos minerais, derivados do petróleo, fenóis, pesticidas, bifenilas policloradas e surfactantes são exemplos de tais classes de compostos. No entanto, esses compostos não são universalmente monitorados, já que sua determinação requer instrumentação sofisticada e pessoal altamente treinado.

Entre os compostos orgânicos, os mais importantes em termos de impacto nos ecossistemas aquáticos são os organoclorados. As razões principais são sua toxicidade e as propriedades químicas que determinam sua persistência nos ambientes aquáticos por longo período de tempo. Essa persistência leva à sua acumulação na cadeia alimentar a níveis que podem produzir efeitos nocivos, principalmente aos organismos que ocupam o topo da cadeia alimentar, incluindo o homem.

Desses compostos organoclorados tratar-se-á em particular, dos pesticidas e das bifenilas policloradas (PCBs) que apresentam alta solubilidade em lipídeos, característica responsável pela sua 
assimilação na cadeia alimentar e por uma possível acumulação nos niveis tróficos superiores.

Os pesticidas, também conhecidos como praguicidas, defensivos agrícolas, biocidas, xenobióticos, produtos agrotóxicos e fitossanitários, são compostos com ação tóxica, os quais têm como ingrediente ativo substâncias formuladas para controlar ou erradicar, de maneira geralmente específica, as doenças e pragas de plantas e animais e os vetores transmissores de doenças no homem. Os benefícios que o uso dos pesticidas proporcionam desde o início de sua utilização são importantíssimos, com significativas mudanças qualitativas e quantitativas na produção de alimentos e no combate a doenças como a Malária, a Doença de Chagas e atualmente a Dengue. Mas, em contrapartida, os efeitos negativos da sua utilização se equiparam, ou até superam os efeitos favoráveis, quando seu uso é realizado indiscriminadamente, sem racionalidade ou critério.

Os subprodutos produzidos pelos pesticidas no processo de degradação podem ser tão tóxicos e persistentes quanto o próprio pesticida. Nos corpos da água, os resíduos e os produtos de degradação dos pesticidas podem ser encontrados na forma dissolvida, incorporados no material particulado ou depositados nos sedimentos. Os pesticidas podem deixar o sistema aquático por diferentes meios como: volatilização, co-destilação, degradação ou via cadeia alimentar (peixes, pássaros e outros animais).

Os pesticidas organoclorados são um grupo de compostos de estrutura química muito variada, que têm em comum a presença de cloro em sua molécula. Estruturalmente, podem ser classificados em quatro principais grupos: o Diclorodifeniletano (DDT) e seus análogos (DDD, DDE, Metoxiclor, etc), os Ciclodienos e compostos similares (Aldrin, Dieldrin, Endosulfan, Heptacloro, etc.), os isômeros do $\mathrm{HCH}$ (hexaclorociclohexano) e o HCB (Hexaclorobenzeno). 
Os PCBs são substâncias de amplo uso industrial como fluidos isolantes em transformadores e capacitores elétricos, óleos lubrificantes, tintas, plastificantes, etc. Têm estes ampla utilização na indústria devido a sua estabilidade química (a ácidos e bases) e térmica, não inflamabilidade e às propriedades elétricas como alta constante dielétrica (que lhes confere a propriedade de isolante).

Os organoclorados entram nos ecossistemas aquáticos através de diferentes fontes que podem ser: escoamento de águas de áreas cultivadas; lixiviação profunda, via lençol freático; entrada direta por operações agrícolas de pulverização, limpeza e manejo de embalagens; efluentes industriais e urbanos; chuva e poeira (deposição atmosférica). O destino e a distribuição dos compostos organoclorados nos ecossistemas aquáticos são aparentemente controlados por dois conjuntos de parâmetros: (1) suas propriedades inerentes, tais como estrutura molecular, estabilidade, concentração, solubilidade em água, polaridade, pressão de vapor, reatividade, volatilidade, etc., e (2) a natureza do ambiente no qual ele está presente, isto é, quantidade de matéria orgânica, $\mathrm{pH}$, temperatura, materiais em suspensão, etc. A tendência acumuladora e os efeitos desses agentes químicos ao longo do tempo podem tornar-se um risco, sendo necessária o monitoramento e vigilância desses produtos nos ecossistemas.

A Portaria 191, de 6 de maio de 1986, do Ministério da Agricultura, proíbe a fabricação, importação e a comercialização de produtos de uso veterinário à base de organoclorados. Já a Portaria Interministerial 19, de 29 de janeiro de 1981, proíbe a produção, o uso e a comercialização dos PCBs e indica a troca por produto equivalente.

Este capítulo tem como objetivo detectar e analisar a situação da contaminação dos corpos de água, nos compartimentos água e sedimento, das bacias formadoras do Alto Jacaré-Guaçu (SP), por 
compostos organoclorados, relacionando-a com uso e ocupação das bacias e verificar se essas concentrações na água estão de acordo com os Padrões de Qualidade Ambiental (PQA) da Legislação Brasileira (CONAMA 20/86).

\subsection{METODOlOGIA PARA A ANÁlise DE COMPOSTOS ORGANOCLORADOS}

5.2.1 Análise na água

A metodologia para a análise de resíduos de compostos organoclorados em água foi baseada em ZUIN (1997):

- amostragem: coleta e estocagem da amostra;

- extração dos analitos da água (extração liquido-liquido);

- evaporação do extrato até $1 \mathrm{~mL}$ em um rotaevaporador a $40^{\circ} \mathrm{C}$

- "clean-up" em coluna de alumina

- eluição com $15 \mathrm{~mL}$ de solvente

- evaporação até $1 \mathrm{~mL}$ em fluxo de nitrogênio

- determinação por cromatografia a gás (GC-ECD)

- quantificação por comparação da resposta do detetor com padrões.

\subsubsection{Amostragem coleta e estocagem da amostra}

Foi coletado 1 litro de água superficialmente, em frascos de vidro âmbar, em duplicata, em cada ponto de amostragem, sendo adicionado, para sua preservação, ácido sulfúrico até $\mathrm{pH}<2$. As amostras foram mantidas em isopor com gelo até a chegada ao laboratório onde foram refrigeradas à temperatura de $4^{\circ} \mathrm{C}$.

\subsubsection{Extração}

A extração de organoclorados nas amostras da água foi realizada pela extração líquido-líqido (LLE), utilizando-se hexano 
como solvente. Um litro de água foi colocado em funil de separação de 2 litros, ao qual agregaram-se 100mL de Hexano, agitando-se e separando-se as fases, retirando-se o solvente e repetindo-se a operação duas vezes com 50 e $50 \mathrm{~mL}$ de Hexano, respectivamente.

A fase orgânica combinada foi seca com sulfato de sódio e o solvente evaporado em um rotaevaporador. Em seguida, o extrato foi transferido para um frasco graduado de $1 \mathrm{~mL}$, para o posterior processo de "clean-up".

\subsubsection{3 "Clean-up" e eluição}

Após a extração dos analitos da matriz com a metodologia adequada fez-se a purificação do extrato com o objetivo de remover os interferentes co-extraídos. O "clean-up" foi feito em coluna de alumina (2g) e a eluição com $15 \mathrm{~mL}$ de Hexano. Após, evaporou-se até $1 \mathrm{~mL}$ em fluxo de nitrogênio.

\subsubsection{Determinação e quantificação}

A determinação e quantificação dos organoclorados foram feitas por cromatógrafo a gás, usando-se a técnica de comparação dos tempos de retenção dos padrões previamente injetados no cromatógrafo. Os padrões foram Hexaclorobenzeno (HCB), uma mistura de 16 organoclorados (Aldrin; 4,4 DDD; 4,4 DDE + Dieldrin; 4,4 DDT; $\alpha$-Endosulfan, $\beta$-Endosulfan; Endosulfan-sulfate; Endrin; Endrin-aldeído; $\alpha-\mathrm{HCH} ; \beta-\mathrm{HCH} ; \gamma-\mathrm{HCH} ; \delta-\mathrm{HCH}$; Heptacloro; Epóxido de Heptacloro e Metoxicloro) e os PCBs 28, 52, 18, 138, 153 e 180. Suas escolhas devem-se à grande utilização, no passado, destes compostos no Brasil e, principalmente, devido a suas ocorrências registradas em trabalhos anteriores nas sub-bacias do Ribeirão do Feijão e do Ribeirão da Onça (CARVALHO, 1996) e na Represa do Broa e tributários (CÁCERES et. al. 1980, CELESTE \& CÁCERES, 1987), além da disponibilidade dos padrões no Laboratório de 
Radioquímica e Química Ambiental do IQSC/USP, onde foram feitas as análises.

A determinação dos organoclorados foi feita usando-se um cromatógrafo Hewlett Packard 5890, série 1l, equipado com detetor de captura de elétrons e injetor split, coluna SBP-5 (coluna capilar de sílica fundida $30 \mathrm{~cm}$ de comprimento, diâmetro interno de $0,25 \mathrm{~mm}$, revestida por um filme de $0,25 \mu \mathrm{m})$. As condições de operação foram as seguintes: temperatura da coluna: para o $\mathrm{HCB}\left(180-280^{\circ} \mathrm{C}\right)$ e para o padrão com a mistura dos organoclorados $\left(210-280^{\circ} \mathrm{C}\right)$; temperatura do injetor $270^{\circ} \mathrm{C}$; temperatura do detector $320^{\circ} \mathrm{C}$; fluxo do gás de arraste, Hidrogênio, $1 \mathrm{mLmin}^{-1}$ e auxiliar, Nitrogênio, $1 \mathrm{mLmin}^{-1}$.

Para se determinar a quantidade de organoclorados existente nas amostras, utilizou-se a seguinte equação:

$\mathrm{R}=(\mathrm{C} . \mathrm{Vf} .100 / \mathrm{Vi}) \cdot \mathrm{r}$

Onde:

$\mathrm{R}$ : resíduo de pesticida $\left(\mu \mathrm{g} \mathrm{L}^{-1}\right)$

C : concentração encontrada através da curva analítica por interpolação $\left(\mu \mathrm{gL}^{-1}\right)$

Vf : volume final de diluição (L)

$\mathrm{Vi}$ : volume inicial da amostra (L)

r : recuperação do método (\%)

\subsubsection{Análise no sedimento}

O esquema geral para a análise de resíduos de compostos organoclorados em sedimento foi baseado em AIROLDI (1997):

- Amostragem: coleta e estocagem da amostra;

- extração dos analitos do sedimento (sistema Soxhlet);

- evaporação do extrato até $1 \mathrm{~mL}$ em um rotaevaporador a $40^{\circ} \mathrm{C}$ 
- "clean-up"

- eluição

- evaporação até $1 \mathrm{~mL}$ em fluxo de nitrogênio

- determinação por cromatografia a gás (GC-ECD)

- identificação e quantificação por comparação da resposta do detetor com padrões;

Como pode observar a análise de resíduos de compostos organoclorados em sedimento é similar a análise em água, mudando só a estocagem das amostras e o sistema de extração.

Foi coletado aproximadamente $200 \mathrm{~g}$ de sedimento em frascos de vidro âmbar e/ou frascos transparentes revestidos com papel alumínio, em duplicata, em cada ponto de amostragem. As amostras foram mantidas em isopor com gelo até a chegada ao laboratório onde foram congeladas. Para a extração, após o degelo, o material foi pesado (10g) e colocado com 150mL de Hexano em um sistema Soxhlet.

Na determinação da quantidade de organoclorados existente nas amostras de sedimento, utilizou-se a seguinte equação:

$\mathrm{R}=(\mathrm{C} . \mathrm{Vf} .100 / \mathrm{m}) \cdot \mathrm{r}$

Onde:

$\mathrm{R}$ : resíduo de pesticida ( $\mu \mathrm{gkg}^{-1}$ )

C : concentração encontrada através da curva analítica por interpolação ( $\left.\mu \mathrm{gkg}^{-1}\right)$

Vf : volume final de diluição (L)

$\mathrm{m}$ : peso da amostra (kg)

$r$ : recuperação do método (\%) 
5.2.3 Determinação do conteúdo de umidade do sedimento por gravimetria

Uma vez que a extração de organoclorados é feita com o sedimento úmido e a quantificação é dada em peso seco, quantificase, também, o conteúdo de umidade do sedimento.

Para determinar o conteúdo de umidade no sedimento foram pesados aproximadamente 5,0g de amostra de sedimento em um cadinho previamente pesado e tarado. Deixou-se a amostra em estufa a $103-105^{\circ} \mathrm{C}$, até peso constante, por um período de 16 a 24 horas, após o qual foi pesada. A diferença de peso antes e depois da secagem correspondeu ao teor de umidade.

\subsection{RESULTADOS}

\subsubsection{Análises na água}

Os resultados referentes as concentrações de organoclorados na água são apresentados na Tabela I (ANEXO). Foram tabulados somente aqueles que foram detectados.

Do grupo do DDT foram detectados a mistura 4,4 DDE + Dieldrin; o 4,4'-DDD e o Metoxicloro. A mistura 4,4 DDE + Dieldrin foi detectada no período das chuvas só no ponto F5, com uma concentração de $0,319 \mu \mathrm{gL}^{-1}$, Já no período de estiagem detectou-se

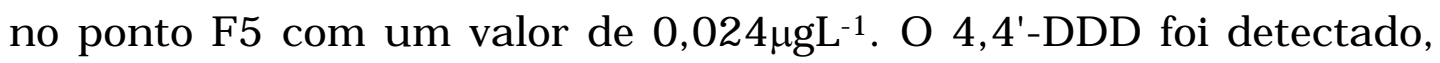
só no período das chuvas, nos pontos M5, F3 e F4 em concentrações de $0,006 \mu g L^{-1}, \quad 0,056 \mu g L^{-1}$ e $0,009 \mu g L^{-1}$, respectivamente. O Metoxicloro, na época das chuvas, detectou-se nos pontos M1 $\left(0,050 \mu \mathrm{gL}^{-1}\right), \mathrm{M} 2\left(0,056 \mu \mathrm{gL}^{-1}\right), \mathrm{F} 2\left(0,080 \mu \mathrm{gL}^{-1}\right), \mathrm{F} 3\left(0,171 \mu \mathrm{gL}^{-1}\right), \mathrm{F} 4$ $\left(0,048 \mu \mathrm{gL}^{-1}\right)$ e F5 $\left(0,052 \mu \mathrm{gL}^{-1}\right)$; no período de estiagem detectou-se no

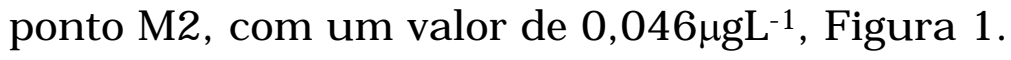



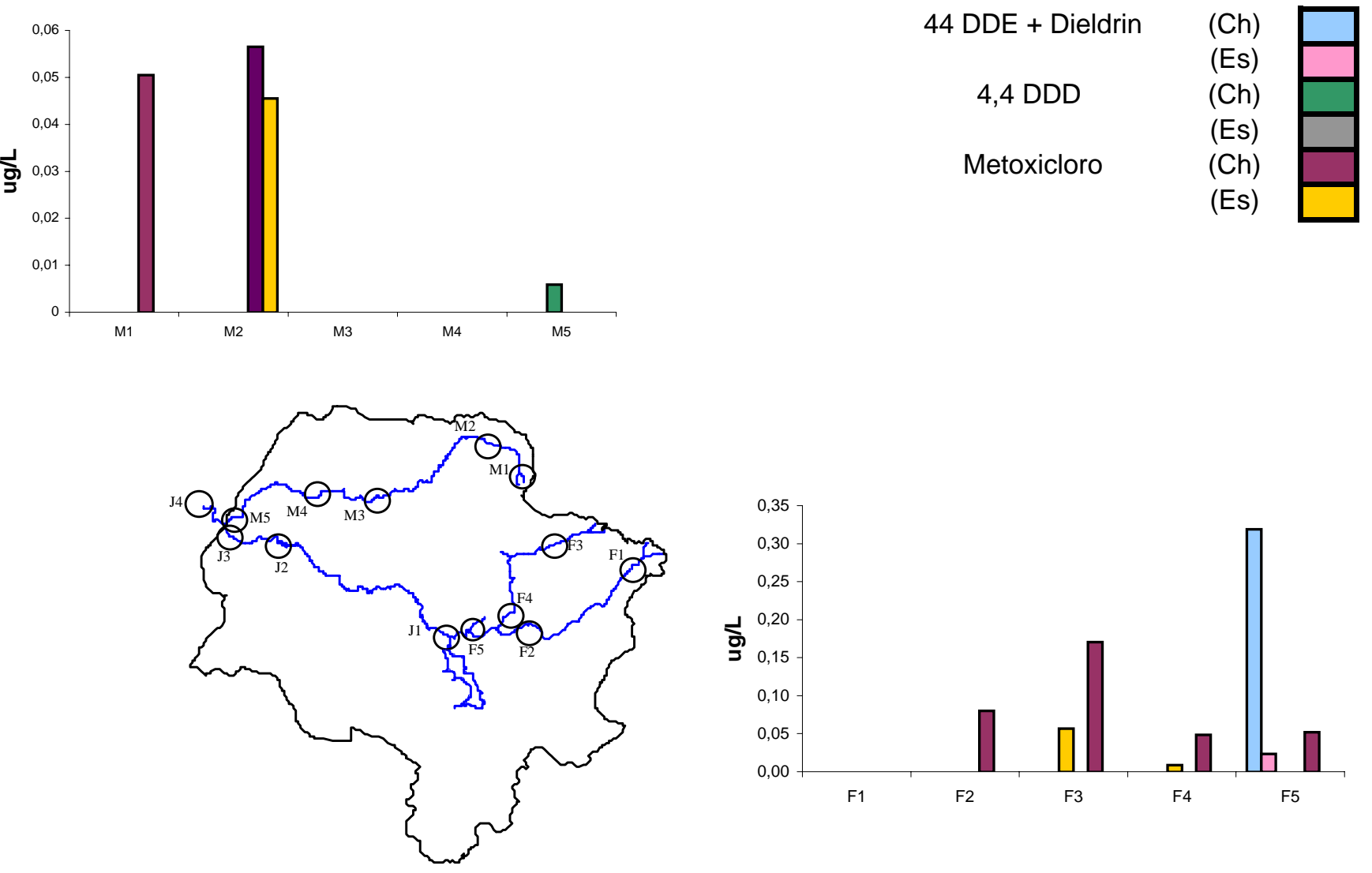

Figura 1. Concentração de 4,4 DDE + Dieldrin, 4,4 DDD e Metoxicloro na águmg/L), na bacia hidrográfica do Alto Jacaré-Guaçu, nas chuva(Gh) e na estiagem(Es) no presente estudo. 
Dos ciclodienos foram encontrados Aldrin, Endrin, Endrinaldeído, $\alpha$-Endosulfan, $\beta$-Endosulfan, Endosulfan-sulfate, Heptacloro e Epóxido de Heptacloro. O Aldrin apresentou valores, no período das

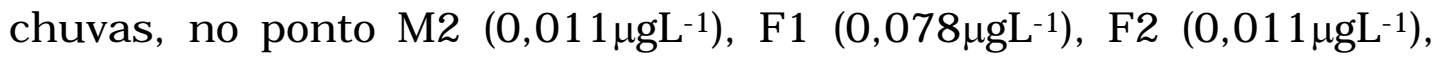
F3 $\left(0,098 \mu \mathrm{gL}^{-1}\right), \mathrm{F} 4\left(0,010 \mu \mathrm{gL}^{-1}\right)$ e F5 $\left(0,015 \mu \mathrm{gL}^{-1}\right)$; já no período de estiagem, foi detectado no ponto M2 (0,019 $\left.\mu \mathrm{gL}^{-1}\right)$; M5 $\left(0,028 \mu \mathrm{gL}^{-1}\right)$;

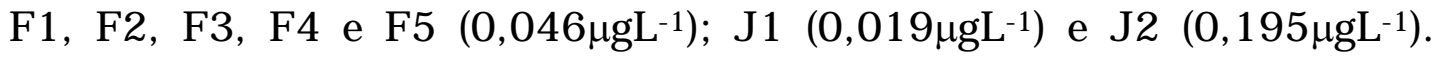
Em relação ao Endrin, no período das chuvas, só foi detectado no ponto F1 com uma concentração de $0,047 \mu \mathrm{gL}^{-1}$; já no período de estiagem, foi detectado em uma altíssima concentração $\left(1,441 \mu \mathrm{gL}^{-1}\right)$ no M2; nos pontos F1, F2 e F5 foi detectado com uma concentração igual de $0,005 \mu \mathrm{gL}^{-1}$; no ponto $\mathrm{Jl}$ foi detectado com uma concentração de $0,004 \mu \mathrm{gL}^{-1}$ e de $0,002 \mu \mathrm{gL}^{-1}$ no ponto J2. O Endrinaldeído, que só foi detectado no período das chuvas, apresentou uma concentração de $0,047 \mu \mathrm{gL}^{-1}$ no ponto F3, Figura 2.

Em termos de Endosulfan total, o isômero $\alpha$ - Endosulfan foi detectado, no período chuvoso, nos pontos M1 e F3, em concentrações de $0,027 \mu g L^{-1}$ e $0,021 \mu g L^{-1}$, respectivamente. Já no período de estiagem, detectou-se, novamente, no ponto M1 $\left(0,225 \mu \mathrm{gL}^{-1}\right)$ e nos pontos M2 e J2, em concentrações de 0,225 $\mu \mathrm{gL}^{-1}$ e $0,521 \mu \mathrm{gL}^{-1}$, respectivamente. O $\beta$-Endosulfan só foi detectado no ponto M3 $\left(0,003 \mu \mathrm{gL}^{-1}\right)$, no período de estiagem. O Endosulfan-sulfato apresentou valores de 0,028 $\mu \mathrm{gL}^{-1}$ (M2) e de 0,020 $\mu \mathrm{gL}^{-1}$ (F3), no período das chuvas; já no período de estiagem, detectou-se no ponto M2, $\left(0,014 \mu \mathrm{gL}^{-1}\right)$, Figura 3. 


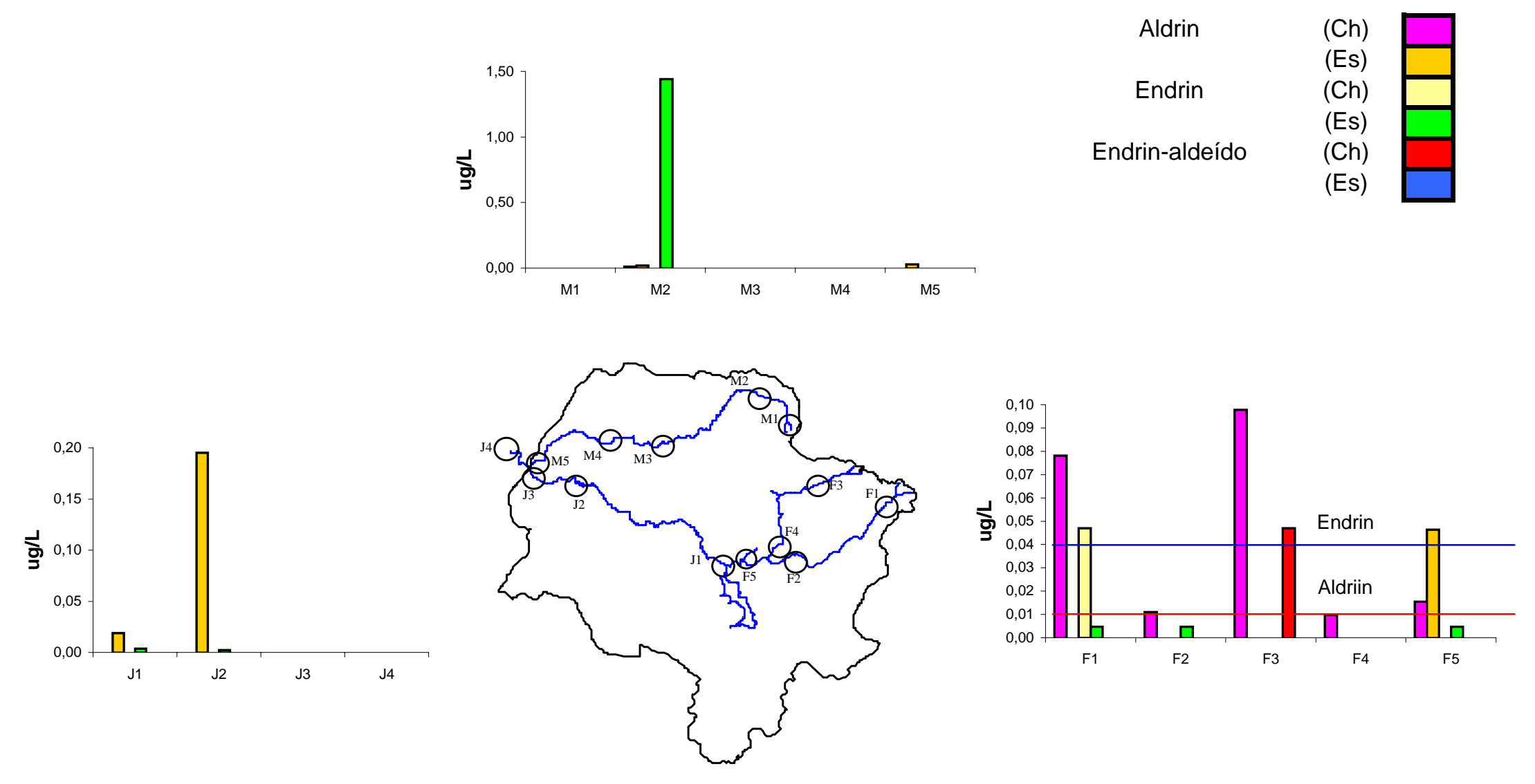

CONAMA 20/86

Figura 2. Concentração de Aldrin, Endrin e Endrin-aldeído na ág(ưg/L), na bacia hidrográfica do Alto Jacaré-Guaçu, nas chuva\$Ch) e na estiagem(Es), no presente estudo. 

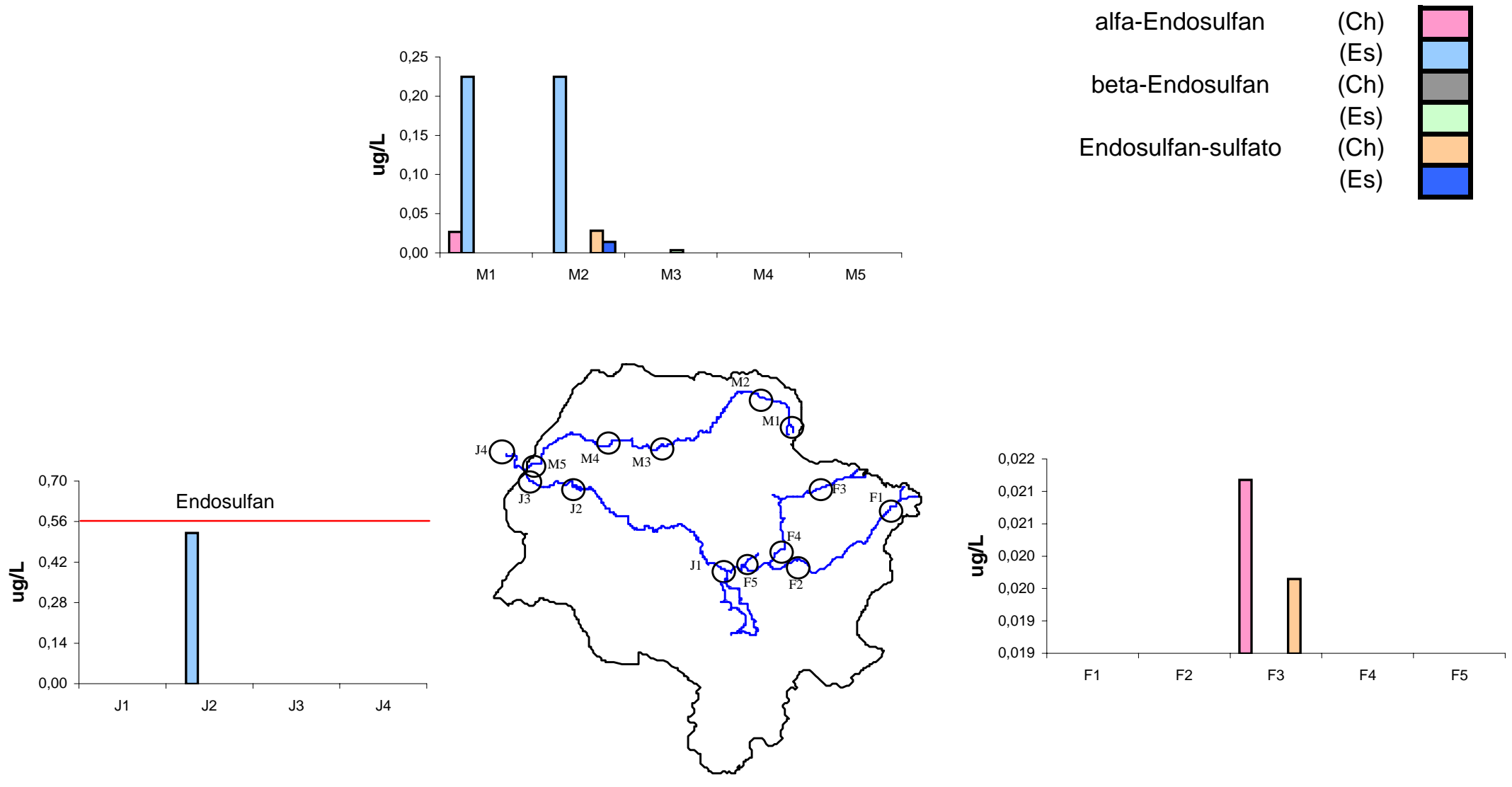

CONAMA 20/86

Figura 3. Concentração de alfa-Endosulfan, beta Endosulfan e Endosulfan-sulfato na águmgr/L), na bacia hidrográfica do Alto Jacaré-Guaçu, nas chuva(sh) e na estiagem(Es) no presente estudo. 
O Heptacloro foi detectado, no período chuvoso, em todos os pontos de amostragem com valores que oscilaram entre $0,049 \mu \mathrm{LL}^{-1}$ (M1) a $0,411 \mu \mathrm{gL}^{-1}(\mathrm{~F} 1)$. No período de estiagem foi detectado em altas concentrações no ponto M2 $\left(1,036 \mu \mathrm{gL}^{-1}\right)$ e no ponto J2 $\left(0,941 \mu \mathrm{gL} \mathrm{L}^{-1}\right)$. O Epóxido de heptacloro, na época das chuvas, detectou-se nos pontos M2, M5, F2, F3, F4 e F5 com valores de: 0,864 $\mu \mathrm{gL}^{-1}, 0,064 \mu g \mathrm{~L}^{-1}$, $0,793 \mu g \mathrm{~L}^{-1}, 0,481 \mu \mathrm{gL}^{-1}, 0,696 \mu \mathrm{gL} \mathrm{L}^{-1}$ e $0,641 \mu \mathrm{gL}^{-1}$ respectivamente. Já na época de estiagem apresentou uma faixa de concentração com valores que oscilaram entre $1,535 \mu \mathrm{gL}^{-1}$ (M2) e $0,010 \mu g \mathrm{~L}^{-1}$ (J4) como demostrado na Figura 4.

O Lindano e seus congêneres só foram detectados no período de estiagem. Em termos de $\mathrm{HCH}$ total, detectou-se o isômero $\alpha-\mathrm{HCH}$, no ponto M2 $\left(0,075 \mu g L^{-1}\right)$, M3 $\left(0,072 \mu g L^{-1}\right)$ e J1 $\left(0,075 \mu g L^{-1}\right)$. Para o isômero $\delta-\mathrm{HCH}$ não houve variações significativas entre os valores encontrados, sendo que o valor mais alto foi detectado no ponto $\mathrm{J} 1$ $\left(0,092 \mu \mathrm{gL}^{-1}\right)$ e o mais baixo no ponto M4 $\left(0,020 \mu \mathrm{gL}^{-1}\right)$. O isômero $\gamma-$ $\mathrm{HCH}$ (Lindano) só foi encontrado no ponto M2 com um valor de $0,036 \mu \mathrm{gL}^{-1}$ (Figura 5).

O HCB só foi quantificado, na época das chuvas, no ponto F4, em uma concentração de $0,022 \mu \mathrm{gL}^{-1}$. Já no período de estiagem, o HCB foi detectado em todos os pontos da bacia, com o maior valor obtido de $0,100 \mu \mathrm{g} \mathrm{L}^{-1}$ (M2) e o menor de $0,002 \mu \mathrm{gL}^{-1}$ (J3) como demostrado na Figura 6.

Quanto aos níveis de PCBs foram detectados: PCB28, PCB52, PCB118, PCB138, PCB153 e PCB180. O PCB28 foi detectado nos pontos M5 e F5 na concentração de 0,005 $\mu \mathrm{gL}^{-1}$ no mês de março. Já no mês de agosto o PCB28 foi detectado nos pontos M4 $\left(0,004 \mu \mathrm{gL}^{-1}\right) \mathrm{e}$ J4 $\left(0,005 \mu \mathrm{gL}^{-1}\right)$. Os PCB118 e PCB 153 só foram detectados no mês de março, com uma concentração de $0,008 \mu \mathrm{gL}^{-1}$ para o PCB18 nos pontos M5 e F5. Já o PCB153 foi detectado nos pontos M5 $\left(0,004 \mu g L^{-1}\right)$, F3 $\left(0,004 \mu g L^{-1}\right)$, F4 $\left(0,004 \mu g L^{-1}\right)$ e F5 $\left(0,011 \mu g L^{-1}\right)$. O 
PCB180 apresentou valores, na época das chuvas, no ponto M2 $\left(0,049 \mu g L^{-1}\right)$, M5 $\left(0,019 \mu g L^{-1}\right), F 1\left(0,036 \mu g L^{-1}\right)$, F2 $\left(0,037 \mu g L^{-1}\right)$, F3 $\left(0,016 \mu g L^{-1}\right)$, F4 $\left(0,015 \mu g L^{-1}\right)$ e F5 $\left(0,172 \mu g L^{-1}\right)$. Já no período de estiagem, detectou-se, novamente, só no ponto M5, com um valor de e 0,016 $\mu \mathrm{gL}^{-1}$. Os PCB52 e PCB138 foram detectados só no ponto M5, no período de estiagem, em concentrações $<0,001 \mu g \mathrm{~L}^{-1}$ e $0,008 \mu \mathrm{gL}^{-1}$, respectivamente (Figura 6). 

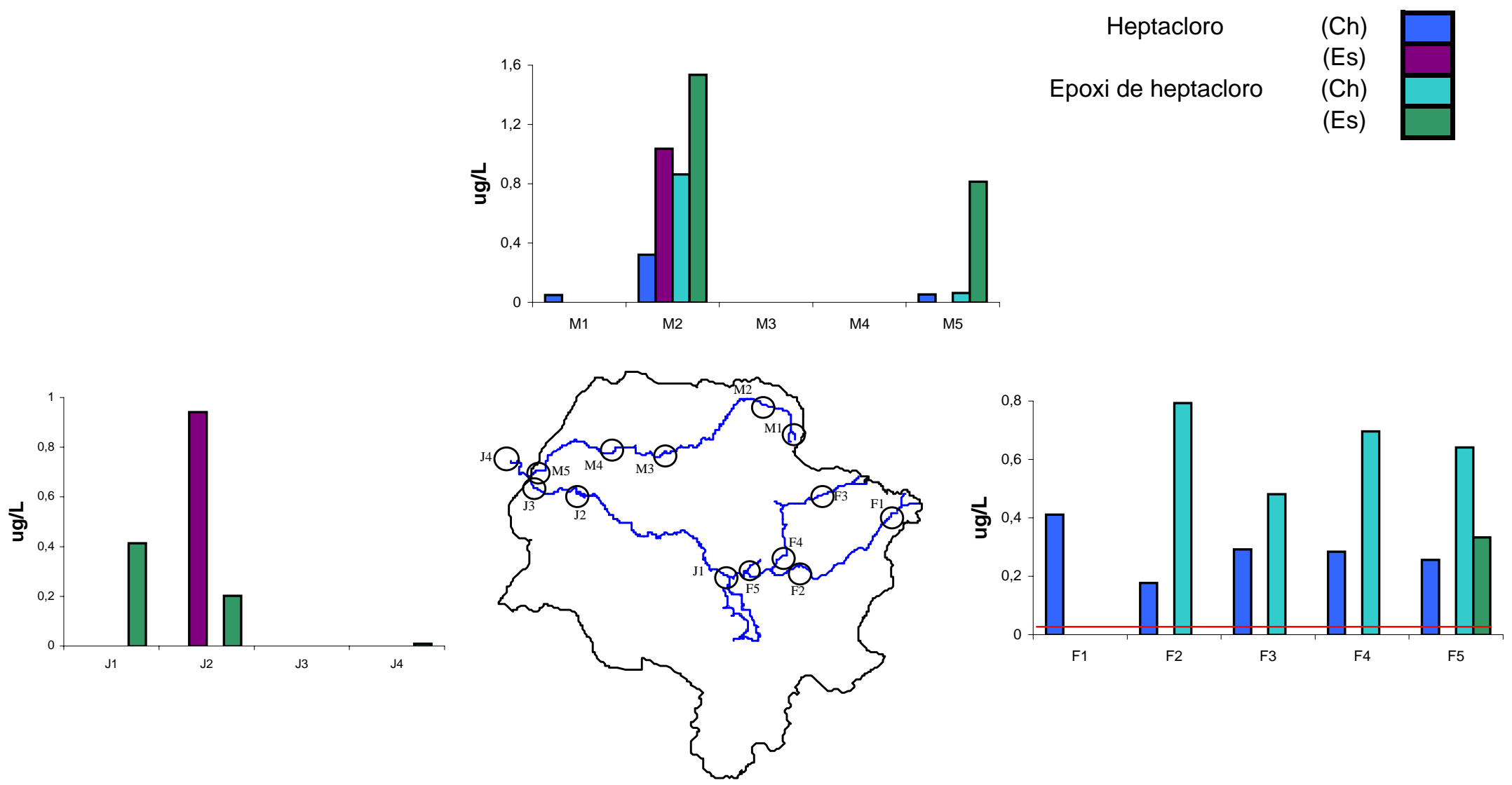

CONAMA 20/86(0,01 ug/L)

Figura 4. Concentração de Heptacloro e Epóxido de heptacloro na á(guga/L), na bacia hidrográfica do Alto Jacaré-Guaçu, nas chuva\$Ch) e na estiagem(Es), no presente estudo. 


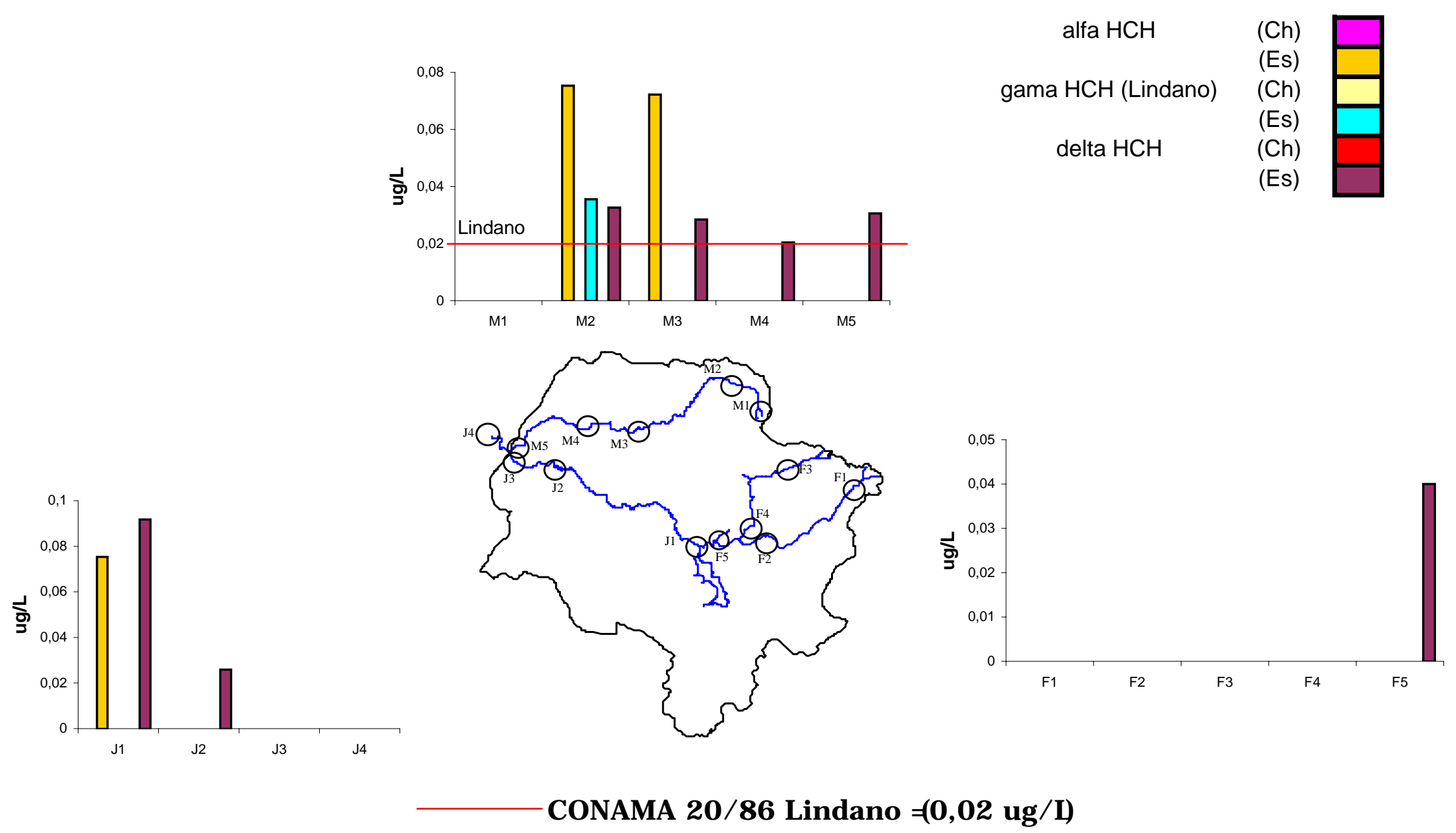

Figura 5. Concentração de alfa-HCH, gama-HCH e beta-HCH na ág(trag/L), na bacia hidrográfica do Alto Jacaré-Guaçu, nas chuvaßCh) e na estiagem(Es), no presente estudo. 

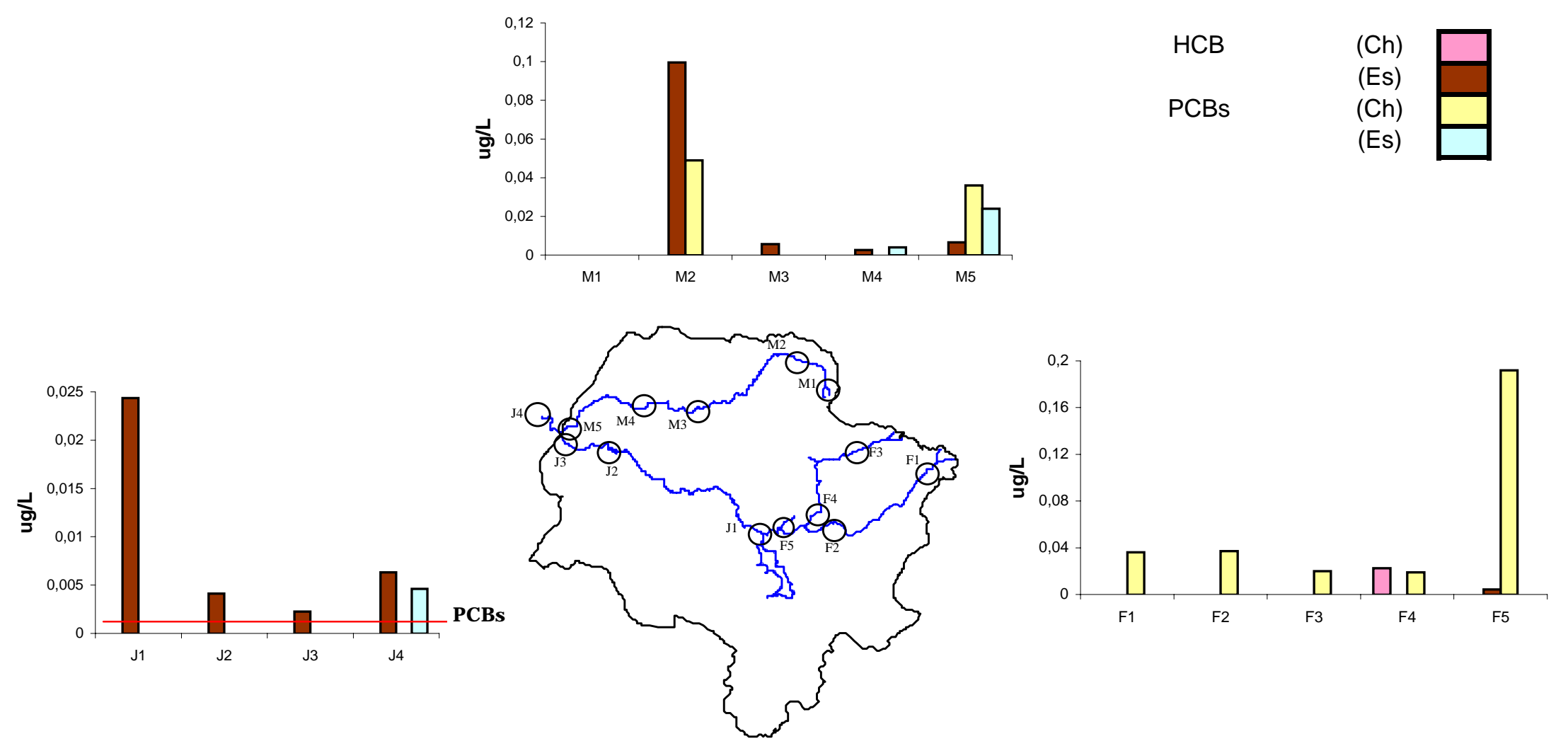

CONAMA 20/86(PCB $=0,001 \mathrm{ug} / \mathrm{I})$

Figura 6. Concentração de HCB e PCBs na águ(aug/L), na bacia hidrográfica do Alto Jacaré-Guaçu, nas chuvas(Ch) e na estiagem(Es), no presente estudo. 


\subsubsection{Análises no sedimento}

Os resultados referentes às concentrações de organoclorados no sedimento são apresentados na Tabela II. Foram tabulados somente aqueles que foram detectados.

Do grupo do DDT foram detectados, na época das chuvas, a mistura 4,4 DDE + Dieldrin; o 4,4'-DDD e o Metoxicloro. A mistura 4,4 DDE + Dieldrin foi detectada nos pontos M1 $\left(21,55 \mu \mathrm{gkg}^{-1}\right)$ e F4 $\left(0,35 \mu \mathrm{gkg}^{-1}\right)$. O 4,4'-DDD foi detectado nos pontos M2, F1, F2, F3 e F5 em concentrações de $3,42 \mu \mathrm{gkg}^{-1}, 2,89 \mu \mathrm{gkg}^{-1}, 3,64 \mu \mathrm{gkg}^{-1}, 2,83 \mu \mathrm{gkg}^{-1} \mathrm{e}$ $1,36 \mathrm{\mu gkg}^{-1}$, respectivamente. O Metoxicloro foi detectado nos pontos

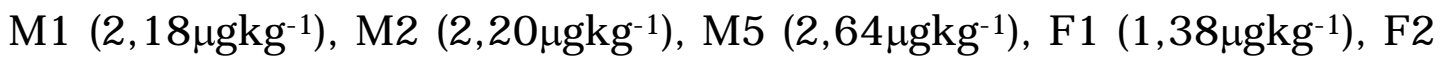
$\left(1,90 \mu \mathrm{gkg}^{-1}\right)$ e F3 $\left(1,71 \mu \mathrm{gkg}^{-1}\right)$. No período de estiagem foram detectados a mistura de 4,4 DDE + Dieldrin e o Metoxicloro. A mistura 4,4'-DDE + Dieldrin foi detectado nos pontos J2 e J3, com valores de $0,91 \mu \mathrm{gkg}^{-1}$ e $1,72 \mu \mathrm{gkg}^{-1}$ e o Metoxicloro nos pontos M3 $\left(1,83 \mu \mathrm{gkg}^{-1}\right)$ e F3 $\left(1,72 \mu \mathrm{gkg}^{-1}\right)$.

Dos ciclodienos, no período das chuvas foram encontrados Aldrin, $\alpha$-Endosulfan, Endosulfan-sulfate, Endrin, Endrin-aldeído, Heptacloro e Epóxido de Heptacloro. O Aldrin apresentou valores no ponto M1 $\left(0,69 \mu \mathrm{gkg}^{-1}\right)$, F1 $\left(0,70 \mu \mathrm{gkg}^{-1}\right)$ e F3 $\left(0,49 \mu \mathrm{gKg}^{-1}\right)$. O isômero $\alpha-$ Endosulfan só foi encontrado no ponto F3, com uma concentração de $0,16 \mathrm{\mu gKg}^{-1}$. O Endosulfan-sulfate apresentou valores de $0,41 \mu \mathrm{Kg}^{-1}$ (M2) e de $0,35 \mu \mathrm{gKg}^{-1}$ (F3). Em relação ao Endrin, este foi detectado nos pontos F3 $\left(5,46 \mu \mathrm{gKg}^{-1}\right)$ e F4 $\left(1,98 \mu \mathrm{gKg}^{-1}\right)$. O Endrinaldeído apresentou uma concentração de $0,79 \mu \mathrm{gKg}^{-1}$ no ponto M2 e de $0,62 \mu \mathrm{gKg}^{-1}$ no ponto F3. O heptacloro, a exemplo das amostras de água, foi detectado em todos os pontos de amostragem com valores que oscilaram entre $14,00 \mu \mathrm{gKg}^{-1}$ (M1) e 1,50 $\mathrm{ggKg}^{-1}$ (M5). O Epóxido de heptacloro foi detectado nos pontos M1, M2, F1, F2, F3 e F4, com valores de: $18,62 \mu \mathrm{gKg}^{-1}, \quad 11,66 \mu \mathrm{KKg}^{-1}, \quad 9,58 \mu \mathrm{KKg}^{-1}, \quad 26,99 \mu \mathrm{KKg}^{-1}$, $20,11 \mu \mathrm{gKg}^{-1}$ e $4,86 \mu \mathrm{gKg}^{-1}$, respectivamente. 
Tabela II. Concentrações de organoclorados no sedimento $\left(\mathrm{mgkg}^{-1}\right)$, no período das chuvas (Ch) e na estiagem (Es), na bacia do Alto Jacaré-Guaçı

\begin{tabular}{|c|c|c|c|c|c|c|c|c|c|c|c|c|c|c|c|}
\hline Ponto de amostragem & Perío & $\mathrm{M} 1$ & $\mathrm{M} 2$ & $\mathrm{M} 3$ & M4 & M5 & F1 & $\mathrm{F} 2$ & F3 & F4 & F5 & $\mathrm{J} 1$ & $\mathrm{~J} 2$ & $\mathrm{~J} 3$ & $\mathrm{~J} 4$ \\
\hline 44 DDE + Dieldrin & $\begin{array}{l}\mathrm{Ch} \\
\mathrm{Es}\end{array}$ & 21,55 & & & & & & & & 0,35 & & & 0,91 & 1,71 & \\
\hline 4,4 DDD & $\mathrm{Ch}$ & & 3,42 & & & & 2,89 & 3,64 & 2,83 & & 1,36 & & & & \\
\hline Metoxicloro & $\mathrm{Ch}$ & 2,18 & 2,20 & & & 2,64 & 1,38 & 1,90 & 1,71 & & & & & & \\
\hline Aldrin & $\begin{array}{l}\text { Es } \\
\text { Ch }\end{array}$ & 0,69 & & 1,82 & & & 0,70 & & $\begin{array}{l}1,72 \\
0,49\end{array}$ & & & & & & \\
\hline alfa Endosulfan & $\mathrm{Ch}$ & & & & & & 0,16 & & & & & & & & \\
\hline Endosulfan - sulfato & $\begin{array}{l}\mathrm{Ch} \\
\mathrm{Es}\end{array}$ & & 0,41 & 0,52 & & & & & 0,35 & & & & & & \\
\hline Endrin & $\mathrm{Ch}$ & & & & & & & & 5,46 & 1,98 & & & & & \\
\hline Endrin - Aldeído & $\mathrm{Ch}$ & & 0,79 & & & & 0,62 & & & & & & & & \\
\hline Heptacloro & $\begin{array}{l}\text { Ch } \\
\text { Es }\end{array}$ & $\begin{array}{l}14,00 \\
1,03\end{array}$ & 5,41 & 1,72 & 2,37 & 1,50 & 9,29 & 12,33 & $\begin{array}{l}7,70 \\
3,04\end{array}$ & $\begin{array}{l}1,53 \\
2,23\end{array}$ & $\begin{array}{l}2,32 \\
21,87\end{array}$ & 2,08 & & 1,77 & \\
\hline Epóxido de heptacloro & $\begin{array}{l}\mathrm{Ch} \\
\mathrm{Es}\end{array}$ & 18,62 & 11,66 & $0 \circ$ & 132 & 019 & 9,58 & 26,99 & 20,11 & 4,86 & 296 & 120 & 111 & 340 & 011 \\
\hline $\begin{array}{l}\text { Lindano } \\
\text { Cont. Tabela II. }\end{array}$ & $\mathrm{Ch}$ & 2,31 & & 0,99 & ו, & 2,96 & $1, \angle 0$ & $2, \pi / 7$ & 2,01 & 3,30 & 2,90 & $1, \angle U$ & 1,11 & 3,40 & 0,11 \\
\hline $\mathrm{HCB}$ & $\begin{array}{l}\text { Ch } \\
\text { Es }\end{array}$ & & 0,09 & & 0,08 & & & & 0,16 & & & 0,45 & 0,27 & & \\
\hline РСB 28 & $\begin{array}{l}\text { Ch } \\
\text { Es }\end{array}$ & 0,25 & 0,29 & 0,24 & 0,44 & 0,26 & 0,28 & 0,23 & 0,28 & $\begin{array}{l}0,37 \\
0,28\end{array}$ & 0,28 & 0,37 & 0.30 & 023 & \\
\hline PCB 52 & Es & & & 0,17 & 0,09 & & 0,11 & & & 0,62 & & 0,26 & 1,46 & 0,01 & \\
\hline PCB 118 & $\mathrm{Ch}$ & & & & & 0,48 & & & & & & & & & \\
\hline PCB 153 & $\mathrm{Ch}$ & 0,22 & 0,22 & & & 0,21 & & & & & & & & & \\
\hline PCB 180 & $\begin{array}{l}\text { Ch } \\
\text { Es }\end{array}$ & 1,11 & 1,10 & & 0,97 & 2,53 & 0,80 & $\begin{array}{l}0,87 \\
0,72 \\
\end{array}$ & 1,70 & $\begin{array}{l}1,16 \\
0,77\end{array}$ & 1,39 & & 1,04 & 0,74 & \\
\hline
\end{tabular}


$\mathrm{Na}$ época de estiagem foram detectados Endosulfan-sulfato, Heptacloro e Epóxido de heptacloro. Em termos de Endosulfan, foi detectado o Endosulfan-sulfato, com o valor de $0,52 \mu \mathrm{gKg}^{-1}$, no ponto

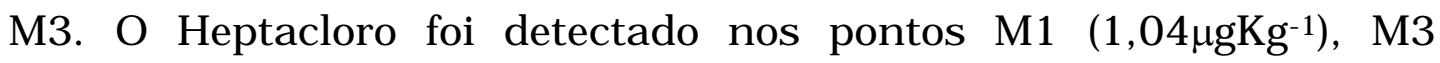
$\left(1,72 \mu \mathrm{gKg}^{-1}\right)$, M4 $\left(2,37 \mu \mathrm{gKg}^{-1}\right)$, F3 $\left(3,04 \mu \mathrm{gKg}^{-1}\right), \mathrm{F} 4\left(2,23 \mu \mathrm{gKg}^{-1}\right), \mathrm{F} 5$ $\left(21,87 \mu \mathrm{gKg}^{-1}\right)$, J1 $\left(2,08 \mu \mathrm{gKg}^{-1}\right)$ e J3 $\left(1,77 \mu \mathrm{gKg}^{-1}\right)$. O Epóxido de heptacloro apresentou uma faixa de concentração com valores que oscilaram entre 5,31 $\mu \mathrm{gKg}^{-1}(\mathrm{~F} 4)$ e $0,11 \mu \mathrm{gKg}^{-1}(\mathrm{~J} 4)$.

Em termos de $\mathrm{HCH}$ total, detectou-se só o isômero $\gamma-\mathrm{HCH}$, o qual foi encontrado no ponto M5, com um valor de $2,96 \mu \mathrm{gKg}^{-1}$, no período das chuvas.

O HCB foi quantificado, no período das chuvas, nos pontos M2 $\left(0,09 \mu \mathrm{gKg}^{-1}\right)$ e F3 $\left(0,16 \mu \mathrm{gKg}^{-1}\right)$. No período de estiagem foi detectado nos pontos M4, J1 e J2 com valores de $0,08 \mu \mathrm{gKg}^{-1}, 0,45 \mu \mathrm{gKg}^{-1}$ e $0,27 \mu \mathrm{gKg}^{-1}$, respectivamente.

$\mathrm{Na}$ coleta de março foram encontrados os mesmos PCBs detectados na água (PCB28, PCB118, PCB153 e PCB180). O PCB28 foi detectado nos pontos M2 e F4 em concentrações de $0,29 \mu \mathrm{gKg}^{-1}$ e $0,37 \mathrm{\mu gKg}^{-1}$, respectivamente. O PCB118 foi detectado só no ponto M5 $\left(0,48 \mu \mathrm{gKg}^{-1}\right)$ e o PCB153 nos pontos M1 $\left(0,22 \mu \mathrm{gKg}^{-1}\right)$, M2 $\left(0,22 \mu \mathrm{gKg}^{-1}\right)$ e M5 $\left(0,21 \mu \mathrm{gKg}^{-1}\right)$. O PCB180 foi detectado em todos os pontos da bacia, com o maior valor obtido de $2,53 \mu \mathrm{gKg}^{-1}$ (M5) e o menor de $0,80 \mathrm{\mu gKg}^{-1}$ (F1). Na coleta de agosto foram quantificados o PCB28, PCB52 e PCB180. Estes compostos apresentaram uma distribuição maior no sedimento do que na água. O PCB28 foi detectado nos pontos M1 $\left(0,25 \mu \mathrm{gKg}^{-1}\right), \quad$ M3 $\quad\left(0,24 \mu \mathrm{gKg}^{-1}\right), \quad$ M4 $\quad\left(0,44 \mu \mathrm{gKg}^{-1}\right)$, M5 (0,26ugKg- $\left.{ }^{-1}\right), F 1\left(0,28 \mu \mathrm{gKg}^{-1}\right)$, F2 $\left(0,23 \mu \mathrm{gKg}^{-1}\right), \mathrm{F} 3\left(0,28 \mu \mathrm{gKg}^{-1}\right), \mathrm{F} 4$ $\left(0,28 \mu \mathrm{gKg}^{-1}\right), \quad$ F5 $\left(0,28 \mu \mathrm{KKg}^{-1}\right), \quad J 1 \quad\left(0,37 \mu g \mathrm{Kg}^{-1}\right), \quad J 2 \quad\left(0,30 \mu \mathrm{Kg}^{-1}\right)$ e J3 $\left(0,23 \mu \mathrm{gKg}^{-1}\right)$. O PCB52 foi detectado nos pontos M3, M4, F1, F4,

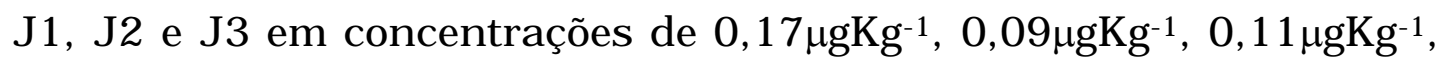
$0,62 \mu \mathrm{gKg}^{-1}, 0,26 \mu \mathrm{gKg}^{-1}, 1,46 \mu \mathrm{gKg}^{-1}$ e $0,01 \mu \mathrm{gKg}^{-1}$, respectivamente. Já 
o PCB180 foi detectado nos pontos M4 $\left(0,97 \mu g \mathrm{Kg}^{-1}\right)$, F2 $\left(0,72 \mu \mathrm{gKg}^{-1}\right)$,

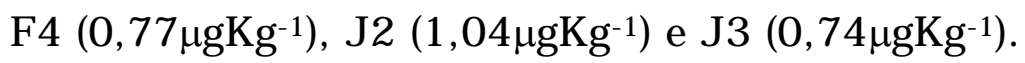

\subsection{DISCUSSÃO}

Os organoclorados estão sujeitos à degradação e transformação no meio ambiente, cuja concentração varia muito dependendo do composto e das condições ambientais. Apesar de não ter sido detectado o DDT, a presença de DDD pode ser indicativo de conversão DDT para DDD (produto da degradação por declorinação), o mesmo acontecendo na mistura DDE + Dieldrin, a qual está composta pelo DDE, produto de degradação do DDT (facilitada em condições aeróbias) e o Dieldrin, Epóxido do Aldrin (CALHEIROS, 1993).

O Aldrin foi detectado na maioria dos pontos de amostragem apresentando valores, em todos os pontos, acima do Padrão CONAMA 20, que é de $0,004 \mu \mathrm{gL}^{-1}$. O Aldrin é de classe toxicológica I (altamente tóxico) ou II (medianamente tóxico), dependendo da formulação. Seu uso como fungicida, no tratamento de sementes, ainda é permitido, sendo usado em culturas de banana, cana-de-açúcar e reflorestamento. As duas últimas ocupam grande parte da área da bacia, o que corrobora sua detecção na maioria dos pontos amostrados. Sua $\mathrm{CL}_{50-24}$ varia de 0,013 a 0,089 $\mathrm{gL}^{-1}$ em diferentes espécies de peixes (CALHEIROS, op.cit.), indicando o potencial tóxico deste produto nos pontos onde sua concentração foi superior a esse valor (F1, F3 e F5).

O Endrin é a forma epóxi do isodrin (endo-endo isômero do Aldrin) e também é o endo-endo isômero do Dieldrin. Possui efeitos tóxicos similares àqueles do Aldrin e Dieldrin, mas é menos estável (CALHEIROS, 1993). Nos pontos onde foi detectado, suas concentrações estiveram acima da CL50-96 (peixes), que está entre 0,0006 e $0,0019 \mu \mathrm{gL}^{-1}$. O Endrin é de classe toxicológica I, inseticida 
com uso freqüentemente em culturas de cana-de-açúcar, algodão, milho e soja.

O Endosulfan, denominado comercialmente como Thiodan, é de classe toxicológica I. O Endosulfan técnico contém de 90\% a 95\% da mistura de dois isômeros $(70 \%$ de $\alpha$-Endosulfan e 30\% de $\beta$ Endosulfan). Analisando as concentrações de Endosulfan, como Endosulfan total, seus valores foram maiores no período de estiagem, nos pontos M1 $\left(0,225 \mu \mathrm{gL}^{-1}\right)$, M2 $\left(0,239 \mu \mathrm{gL}^{-1}\right)$ e J2 $\left(0,521 \mu \mathrm{gL}^{-1}\right)$.

Nos pontos onde foi detectado o Heptacloro, suas concentrações estiveram acima do limite da resolução CONAMA 20 $\left(0,010 \mu \mathrm{gL}^{-1}\right)$. O Heptacloro pertence à classe toxicológica I; sendo inseticida (formicida e cupinicida) com uso permitido, no passado, em culturas de cana-de-açúcar, banana e reflorestamento. O Heptacloro sofre epoxidação tornando-se Epóxido de heptacloro, o qual é mais persistente e tóxico que seu produto de origem (Heptacloro) (CALHEIROS, 1993). O Epóxi de heptacloro, a exemplo de seu precursor, apresentou alta distribuição e altas concentrações na bacia.

Os congêneres do $\mathrm{HCH}$ só foram detectados no período de estiagem. Na formulação o isômero $\alpha-\mathrm{HCH}$ é o que apresenta maior proporção (53 - 70\%), o $\gamma$-HCH (11 a 18\%), o $\beta$-HCH (3 - 14\%), o $\delta$ HCH (6 - 10\%) e o $\in-\mathrm{HCH}$ (3 - 5\%). Os isômeros $\gamma$ (Lindano) e $\alpha$ são estimulantes do sistema nervoso central e o $\beta$ é depressor e praticamente atóxico sendo, entretanto, capaz de condicionar intoxicações crônicas devido à sua retenção prolongada em tecidos adiposos. O Lindano, do ponto de vista de toxicidade aguda, é o mais tóxico (classe toxicológica I) e só foi encontrado no ponto M2 com um valor acima do limite CONAMA 20, que é de $0,02 \mu \mathrm{gL}^{-1}$. O Lindano teve seu uso permitido em grande escala nas partes aéreas e/ou sementes de culturas de algodão, cacau, café, cana-de-açúcar, coco, frutas, hortaliças, leguminosas e mandioca. 
O HCB só foi quantificado, na época das chuvas, no ponto F4 e na estiagem em todos os pontos da bacia com um valor máximo no ponto M2 $\left(0,100 \mu \mathrm{gL}^{-1}\right)$, o qual é o valor limite para águas com fins de abastecimento público (MINISTÉRIO DA SAÚDE, 1990); embora não exista PQA para este produto. O HCB é um fungicida de classe toxicológica - I. Pode também ser liberado durante processos industriais de cloração (cloração do benzeno) ou como impureza na produção de pesticidas. É utilizado na produção de tintas e preservantes de madeiras.

Pelos resultados das concentrações de pesticidas obtidos na bacia hidrográfica do Alto Jacaré-Guaçu, as áreas de influência dos pontos M3, M4 e J3 foram consideradas como aceitáveis em termos de PQA, e os outros pontos e suas áreas de influência foram considerados não aceitáveis (Figura 7). Esses dados podem estar relacionados ao uso da bacia hidrográfica por pequenos proprietários, cuja maioria utiliza o solo para pastagens e culturas temporárias, onde poderiam estar sendo utilizados esses pesticidas. Tais pesticidas, apesar de serem proibidos por lei, poderiam estar sendo comercializados. A comercialização ilegal dificulta o controle por parte das autoridades. Nas áreas de influência dos pontos M3, M4 e J3 o uso do solo predominante é a monocultura de cana-de-açúcar, que provavelmente não faz uso desses produtos, como foi constatado por BRONDI (2000).

Em geral os níveis de PCBs detectados na bacia foram maiores e mais uniformemente distribuídos no período das chuvas, possivelmente pelo efeito desta na lixiviação do solo. Já no período de estiagem, só foram detectados nos pontos M4, M5 e J4 (após a área urbana). Devido à grande persistência desses compostos no ambiente, isto pode ser um indicativo de depósitos industriais ainda existentes. A Resolução CONAMA 20 fixa um valor de 0,001 $\mu \mathrm{gL}^{-1}$ para PCBs total, valor ultrapassado em todos os pontos onde foram detectados. 


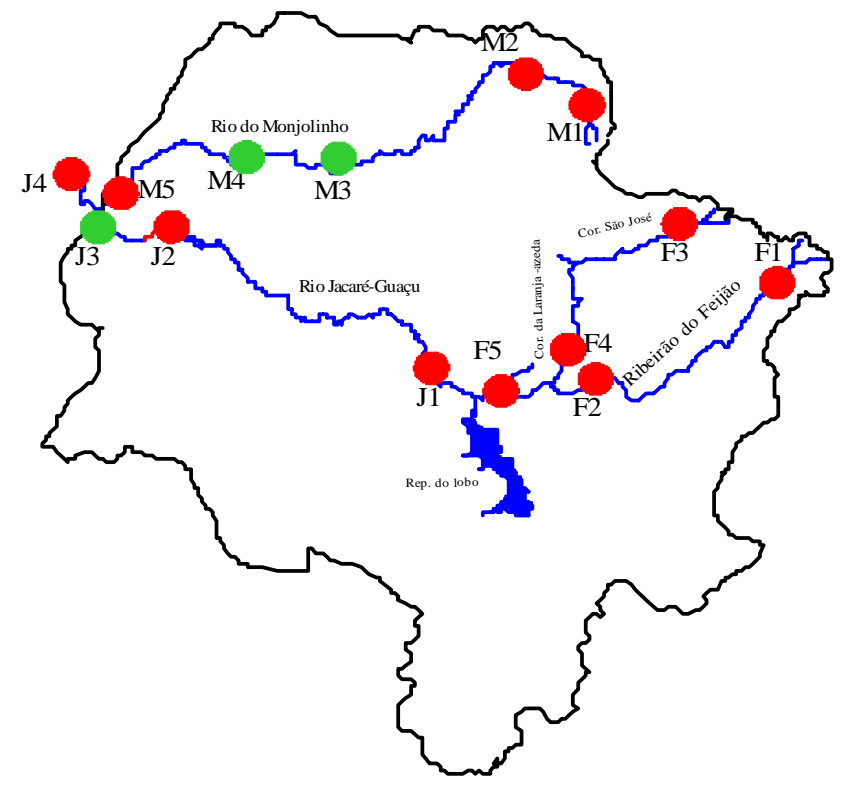

CONAMA 20/86

$\square$ Atende

Não atende

Figura 7. Mapa da bacia do Alto Jacaré-Guaçu, classificada segundo a concentração de pesticidas organoclorados, detectados no presente trabalho, que atendem ou não, os PQA da Resolução CONAMA 20/86. 
Uma análise comparativa dos resultados das concentrações de organoclorados obtidos no presente trabalho com os reportados na literatura (CARVALHO, 1996; CÁCERES, et. al., 1980; Del Grande, 2001; NAVAS 1985; CALHEIROS 1993 e CETESB, 1996), é apresentada na Tabela III.

Tabela III. Concentração máxima de organoclorados ( $\left.\mu g \mathrm{~L}^{-1}\right)$ em coletânea de vários trabalhos na literatura para intercomparação com os resultados encontrados na bacia do Alto Jacaré-Guaçu.

\begin{tabular}{lcccccccc}
\hline Corpo de água & HCB & HCH & Lindano & Heptacloro & Aldrin & DDT & PCBs \\
& & Total & & Total & & & Total \\
\hline Valor CONAMA 20 & & & 0,02 & 0,02 & 0,004 & 0,001 & 0,001 \\
Rio do Feijão a & na & $<0,001$ & nd & 0,008 & na & 0,006 & na \\
Tributários represa do Lobo b & na & 0,357 & 0,020 & 0,080 & 0,048 & 0,040 & na \\
Rio Piracicaba c & 0,026 & na & na & na & na & na & nd \\
Represa de Barra Bonita d & na & 0,160 & 0,030 & 0,010 & na & na & na \\
Represa de Barra Bonita ${ }^{2}$ & nd & 0,050 & 0,007 & nd & nd & 0,070 & nd \\
Represa Billings ${ }^{f}$ & $<0,003$ & 0,070 & 0,034 & 0,008 & 0,014 & nd & na \\
Alto Jacaré-Guaçug & 0,100 & 0,144 & 0,036 & 2,571 & 0,195 & 0,060 & 0,175 \\
Ribeirão do Feijãog & 0,004 & 0,040 & nd & 0,900 & 0,046 & nd & 0,175
\end{tabular}

a(CARVALHO, 1996); b(CÁCERES, et. al., 1980); c(Del Grande, 2001); d(NAVAS (S/D); e(CALHEIROS 1993); f(CETESB, 1996) e g(presente trabalho). na = não analisado; nd = não detectado

Comparando-se os dados apresentados na tabela III, pode-se observar que, grosso modo, as concentrações de organoclorados estão na mesma ordem de grandeza, na bacia do Alto Jacaré-Guaçu, com os dados reportados pelos diferentes autores, embora o Heptacloro 
(Heptacloro total) apresentasse concentrações até 300 vezes acima das reportadas na literatura.

Já no sedimento, em relação às concentrações de organoclorados detectadas no período das chuvas verificou-se, de modo geral, que a quantidade e a diversidade foram mais elevadas quando comparadas com as detectadas na água, o que era esperado pelo efeito das chuvas na lixiviação do solo e, por conseguinte, aumento do material particulado (capítulo 3), ao qual os organoclorados têm alta afinidade. Já no período de estiagem, tanto a quantidade como a diversidade dos organoclorados foi menor.

No sedimento, semelhante a água, os pesticidas Heptacloro e seu epóxi apresentaram altas concentrações nos dois períodos estudados, em concentrações consideradas com potencial efeito adverso na biota presente (SMITH, et. al., 1996). A mistura 44 DDE + Dieldrin, no período das chuvas, no ponto M1, apresentou também uma concentração elevada de $21,55 \mu \mathrm{gkg}^{-1}$, sendo o DDE produto de degradação do DDT. Esse alto valor pode indicar o uso de DDT na área de influência do ponto de amostragem em anos anteriores.

O Aldrin e o Lindano só foram detectados no sedimento no período das chuvas, em concentrações próximas à reportada para a Represa Billings de 2,5 $\mathrm{gkg}^{-1}$ e 2,0 $\mathrm{ggkg}^{-1}$, respectivamente (CETESB, 1996). O valor máximo detectado como PCBstotal foi $3,22 \mu \mathrm{gkg}^{-1}$, concentração considerada baixa se comparada às reportadas para o Rio Piracicaba - 88,65 $\mu \mathrm{gkg}^{-1}$ (Del Grande, 2001) e para as represas de Barra Bonita - 26,47 $\mathrm{\mu gkg}^{-1}$ (CALHEIROS 1993) e Billings - 664 $\mu \mathrm{gkg}^{-1}$ (CETESB, 1996). 


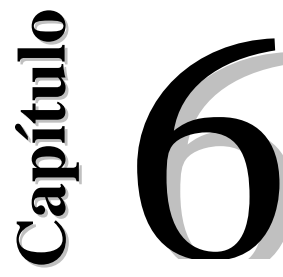

\section{ANÁLISE DA COMUNIDADE DE MACROINVERTEBRADOS NA BACIA DO ALTO JACARÉ-GUAÇU (SP)}

\subsection{INTRODUÇÃO}

Cada ser vivente ocupa na natureza um nicho determinado. Isto quer dizer que a espécie, no meio em que vive, é exigente em relação à qualidade física, química e estrutural do meio, e assim como as demais espécies que ocupam o mesmo habitat. As mudanças físicas e químicas que ocorrem no ambiente se refletem na composição dos nichos, causando prejuízo às espécies sensíveis e permitindo selecionar as espécies resistentes às mudanças ambientais, as quais passam a ser espécies indicadoras do ambiente em questão.

As espécies indicadoras de poluição por despejos domésticos são, em geral, formas resistentes à falta parcial ou total de oxigênio, ao soterramento decorrente do material particulado em suspensão, à baixa intensidade de luz e à presença de compostos químicos tóxicos. A poluição no ambiente varia de acordo com a proporção do despejo em relação ao corpo da água receptor, sendo comuns na literatura as expressões: ambiente "muito poluído", "medianamente poluído" ou "pouco poluído".

A avaliação da poluição orgânica de um sistema aquático utilizando a análise da biota presente pode ser feita através de três tipos principais de medidas:

- Determinação de Índices comunitários (diversidade; riqueza, etc.)

- Aplicação de Índices bióticos (Sapróbio, BMWP, etc);

- Aplicação de Índices de similaridade (Jaccard, Sorensen, PSc, etc).

$\mathrm{Na}$ avaliação da qualidade da água através de organismos indicadores os macroinvertebrados bentônicos têm sido os mais 
freqüentemente utilizados principalmente em sistemas lóticos, sendo que sua utilização se justifica pelas seguintes razões (TRIVINHOSTRIXINO \& NASCIMENTO 2000):

- A estrutura da comunidade de macroinvertebrados reflete a qualidade ambiental uma vez que diferentes macroinvertebrados têm diferentes níveis de tolerância a poluentes, erosão, modificação do substrato e regime hídrico;

- São relativamente grandes, o que facilita sua coleta e posterior identificação;

- São relativamente sedentários, permitindo correlações diretas com o ambiente em que ocorrem;

- Possuem, em geral, ciclos de vida longos, permitindo a análise de várias gerações e os efeitos a longo prazo.

Os macroinvertebrados bentônicos de água doce são dominados pelos insetos que apesar de constituírem um grupo essencialmente terrestre, desenvolveram adaptações que lhes permitiram explorar com sucesso os vários sistemas aquáticos, tanto lóticos quanto lênticos. A principal adaptação relaciona-se à respiração na água, de tal forma que diferentes insetos desenvolveram diferentes mecanismos de obtenção de oxigênio, alguns mais, outros menos eficientes. Neste aspecto, a distribuição destes está condicionada à sua capacidade de respirar na água.

Entre os insetos que têm verdadeira respiração aquática estão as formas imaturas de representantes de várias ordens que exibem maior ou menor sensibilidades quanto ao déficit de oxigênio dissolvido na água. Assim, grupos como ninfas de Plecoptera e Ephemeroptera são altamente dependentes de locais com elevada oxigenação, enquanto outros, como, por exemplo, algumas larvas de Chironomidae (Diptera), são menos exigentes e passam grande parte 
do ciclo de vida no interior de sedimentos de lagos e rios, muitas vezes em condições anóxicas.

A maior ou menor susceptibilidade desses insetos à disponibilidade de oxigenação das águas torna-os de grande importância como indicadores das condições ambientais. Além disso, também são considerados indicadores sanitários, principalmente porque os sedimentos onde vivem são, em geral, acumuladores de substâncias persistentes tóxicas como pesticidas e metais pesados provenientes de atividades antrópicas.

O emprego de organismos indicadores de qualidade de água através da comunidade de macroinvertebrados bentônicos nos países desenvolvidos é amplamente aplicado no monitoramento e classificação de recursos hídricos. No Brasil, esta classificação baseia-se, principalmente, no uso de análises físicas e químicas da água, embora já haja grande esforço, como o da CETEC (MG), da FEEMA (RJ) e da CETESB (SP), na adaptação e implantação de análises das comunidades bentônicas em programas de monitoramento.

De acordo com a legislação vigente, os corpos hídricos brasileiros são classificados segundo seus usos preponderantes e suas águas são enquadradas em diferentes classes, conforme Resolução Federal CONAMA 20/86. Os corpos de água que compõem a bacia hidrográfica do Alto Jacaré-Guaçu enquadram-se na classe 2, categoria que incluí os sistemas cujas águas são destinadas, entre outros usos, à proteção das comunidades aquáticas.

Com o objetivo de avaliar a qualidade da água de dois rios principais dessa bacia hidrográfica foi feita a análise da comunidade de macroinvertebrados em locais com diferentes usos da terra e da água. No presente estudo são analisados aspectos relacionados à estrutura taxonômica, dominância e diversidade e são aplicados índices bióticos de qualidade da água e de similaridade. 


\subsection{MATERIAIS E MÉTODOS}

\subsubsection{Amostragem, triagem e identificação}

As coletas da fauna foram realizadas com o auxílio de rede de mão, com malha de $0,5 \mathrm{~mm}$, a qual permite explorar os vários biótopos e substratos de um corpo de água, como margens, vegetação e fundo e, desta forma, obter um conjunto de exemplares mais representativos da fauna do local. Com a finalidade de padronizar as coletas e poder comparar as informações obtidas nos diferentes pontos de amostragem, utilizou-se um esforço de amostragem (tempo) de 5 minutos, conforme recomendações de FONTOURA (1985).

As amostras foram acondicionadas em recipientes plásticos contendo água do local e posteriormente, no Laboratório de Entomologia Aquática, DHb/UFSCar, foram lavadas sobre peneiras de malha fina $(0,5 \mathrm{~mm})$. Para facilitar a triagem, as amostras foram submetidas várias vezes a uma solução saturada de cloreto de sódio em bandejas brancas sobre fonte de luz (bandejas transiluminadas) e os exemplares retirados diretamente da superfície da suspensão com auxílio de pinças e estiletes. Os organismos foram preservados em álcool a 70\%, exceto os exemplares de Oligochaeta, que foram previamente fixados em solução de formol a $4 \%$ durante $24 \mathrm{~h}$.

Os exemplares analisados sob microscópio estereoscópico e/ou montados em lâminas para análise em microscópio ótico foram identificados até os níveis taxonômicos possíveis, com auxílio de literatura especializada (McCAFFERTY, 1981; ROLDAN, 1988; BRIKHURST \& MARCHESE, 1989; TRIVINHO-STRIXINO \& STRIXINO, 1995), sob a orientação da Profa. Dra. SUSANA TRIVINHO STRIXINO. 


\subsection{2 Índices da estrutura da comunidade}

A estrutura da comunidade foi determinada através da composição taxonômica, do grau de dominância de cada táxon e de índices comunitários (riqueza, diversidade de Margalef e de Shannon, de equitatividade e de dominância de McNaughton).

Para o grau de dominância foram estabelecidas as seguintes classes, conforme STRIXINO \& TRIVINHO-STRIXINO (1998): Eudominante $>10 \%$; Dominante $>5-10 \%$; Subdominante $>2-5$ e recessivos $1-2 \%$. O índice de dominância de McNaughton $\left(\mathrm{D}_{2}\right)$ foi determinado de acordo com KANIEWSKA-PRUS \& KIDAWA (1983), que leva em consideração o grau de participação dos dois táxons mais abundantes em relação ao total de indivíduos da amostra; os valores do índice variam de 0 a 1 .

Considerando que não foi possível a identificação dos táxons até o nível de espécie, os índices aqui aplicados foram calculados com base no menor nível taxonômico obtido.

\subsection{2 Índices bióticos}

Segundo MOSS in TEIXEIRA (1993), a identificação taxonômica em nível de família pode ser usado com sucesso no monitoramento da poluição, sendo seu uso suficiente para demonstrar a resposta dos macroinvertebrados ao estresse ambiental, e de uso generalizado na aplicação de índices bióticos da qualidade da água.

Entre os índices bióticos reportados pela literatura foram selecionados para a aplicação na bacia hidrográfica os seguintes índices: Índice Biótico Belga (DE PAUW \& VANHOOREN, 1983) e o BMWP - score system (ARMITAGE et al., 1983).

A avaliação da qualidade biológica de um curso de água, através do Índice Biótico Belga (IBB), se faz pela determinação de um índice biótico cujo valor varia de 0 a 10. O método dispensa identificações em nível de espécie. São considerados o número de unidades sistemáticas de cada grupo taxonômico (UTOs); o grau de 
sensibilidade de ordens ou famílias e o número total de unidades sistemáticas presentes na amostra. A determinação do IBB se faz utilizando-se a Tabela I.

Tabela I. Diagrama para determinação do Índice Biótico Belga (IBB) com modificações (FONTURA, 1985 e TRIVINHO-STRIXINO \& NASCIMENTO, 2000).

\begin{tabular}{|c|c|c|c|c|c|c|c|}
\hline \multicolumn{2}{|c|}{$\begin{array}{c}\text { I } \\
\text { Grupos Faunísticos }\end{array}$} & \multirow[t]{2}{*}{ II } & \multicolumn{5}{|c|}{$\begin{array}{c}\text { III } \\
\mathrm{N} \text { o total de unidades sistemáticas na } \\
\text { amostra }\end{array}$} \\
\hline & & & $0-1$ & $2-5$ & $6-10$ & $\begin{array}{l}11- \\
15\end{array}$ & $\begin{array}{c}16 \text { ou } \\
+\end{array}$ \\
\hline & & & & & IBB & & \\
\hline 1 Plecoptera ou & 1 & + de 1 UTO & - & 7 & 8 & 9 & 10 \\
\hline Leptophlebiidae & 2 & $1 \mathrm{UTO}$ & 5 & 6 & 7 & 8 & 9 \\
\hline 2 Trichoptera & 1 & + de 1 UTO & - & 6 & 7 & 8 & 9 \\
\hline $\mathrm{C} / \mathrm{tubo}$ & 2 & $1 \mathrm{UTO}$ & 5 & 5 & 6 & 7 & 8 \\
\hline 3 Ancylidae & 1 & + de 1 UTO & - & 5 & 6 & 7 & 8 \\
\hline Ephemeroptera * & 2 & 1 UTO & 3 & 4 & 5 & 6 & 7 \\
\hline $\begin{array}{c}\text { Aphelocheirus } \\
\text { Odonata } \\
\text { Gamaridae } \\
\text { Mollusca** }\end{array}$ & 0 & $\begin{array}{l}\text { Todas as } \\
\text { UTOs acima } \\
\text { ausentes }\end{array}$ & 3 & 4 & 5 & 6 & 7 \\
\hline $\begin{array}{l}5 \text { Asellus ou } \\
\text { Hirudinea ou } \\
\text { Sphaeridae ou } \\
\text { Hemiptera }{ }^{* * *}\end{array}$ & 0 & $\begin{array}{l}\text { Todas as } \\
\text { UTOs acima } \\
\text { ausentes }\end{array}$ & 2 & 3 & 4 & 5 & - \\
\hline $\begin{array}{l}6 \text { Tubificidae ou } \\
\text { Chironominae } \\
\text { (Chironomus) }\end{array}$ & 0 & $\begin{array}{l}\text { Todas as } \\
\text { UTOs acima } \\
\text { ausentes }\end{array}$ & 1 & 2 & 3 & - & - \\
\hline $7 \quad$ Eristalinae & 0 & $\begin{array}{l}\text { Todas as } \\
\text { UTOs acima } \\
\text { ausentes }\end{array}$ & 0 & 1 & 1 & - & - \\
\hline
\end{tabular}


A avaliação da qualidade da água é feita comparando-se os valores obtidos com as classes de qualidade apresentada na Tabela II.

Tabela II. Classificação de qualidade da água conforme o IBB.

\begin{tabular}{|c|c|c|c|}
\hline Classe & Faixa & Qualidade da água & $\begin{array}{c}\text { Cor indicativa } \\
\text { (Padrão) }\end{array}$ \\
\hline I & $9-10$ & Água não Poluída & \\
\hline II & $7-8$ & Ligeiramente Poluída & \\
\hline III & $5-6$ & Moderadamente Poluída & \\
\hline IV & $3-4$ & Muito Poluída & \\
\hline V & $0-2$ & Fortemente Poluída & \\
\hline
\end{tabular}

O Índice biótico BMWP também leva em consideração o nível de famílias, ordenando-as em 9 grupos, seguindo um gradiente de menor a maior tolerância à poluição. A cada família corresponde uma pontuação (score), que varia de 1 a 10 , sendo que famílias mais sensiveis recebem as maiores pontuações.

A tabela III indica a pontuação das famílias coletadas na bacia do Alto Jacaré-Guaçu de acordo com o grau de tolerância proposto no índice. Foram incluídas na tabela famílias que não constam no índice original, segundo CETEC (1994), TRIVINHO-STRIXINO \& NASCIMENTO (2000) e presente trabalho. 
Tabela III. Famílias coletadas na bacia do Alto Jacaré-Guaçu e seus respectivos valores de tolerância, segundo o método BMWP, com modificações.

\begin{tabular}{|c|c|}
\hline Famílias & Pontos \\
\hline $\begin{array}{l}\text { PLECOPTERA: Grypopterigidae. } \\
\text { TRICHOPTERA: Leptoceridae, Odontoceridae. }\end{array}$ & 10 \\
\hline $\begin{array}{l}\text { DIPTERA: Dixidae. } \\
\text { ODONATA: Calopterygidae, Gomphidae, Libellulidae, } \\
\text { Megapodagrionidae. }\end{array}$ & 8 \\
\hline $\begin{array}{l}\text { EPHEMEROPTERA: Caenidae, Leptohyphidae. } \\
\text { TRICHOPTERA: Polycentropodidae. }\end{array}$ & 7 \\
\hline $\begin{array}{l}\text { TRICHOPTERA: Hydroptilidae. } \\
\text { LEPIDOPTERA: Pyralidae. } \\
\text { ODONATA: Coenagrionidae. } \\
\text { CRUSTACEA: Palaemonidae. }\end{array}$ & 6 \\
\hline $\begin{array}{l}\text { HEMIPTERA: Corixidae, Naucoridae, Notonectidae, Pleidae, Veliidae. } \\
\text { DIPTERA: Tipulidae, Simuliidae. } \\
\text { TRICHOPTERA: Hydropsychidae. } \\
\text { COLEOPTERA: Curculionidae, Dryopidae, Dytiscidae, Hydrophilidae, } \\
\quad \text { Notoridae, Syrtidae. }\end{array}$ & 5 \\
\hline $\begin{array}{l}\text { EPHEMEROPTERA: Baetidae. } \\
\text { COLEOPTERA: Elmidae. } \\
\text { HIDRACARINA }\end{array}$ & 4 \\
\hline $\begin{array}{l}\text { MOLLUSCA: Physidae, Lymnaeidae. } \\
\text { HIRUDINEA: Glossiphonidae. } \\
\text { DIPTERA: Ceratopogonidae, Culicidae. }\end{array}$ & 3 \\
\hline DIPTERA: Chironomidae. & 2 \\
\hline OLIGOCHAETA & 1 \\
\hline
\end{tabular}

CETEC, 1994: grupos em itálico

TRIVINHO-STRIXINO \& NASCIMENTO, 2000: sublinhados

Presente trabalho: negrito

O índice de qualidade da água é calculado pela somatória dos pontos (scores) e a avaliação é feita comparando-se os valores obtidos na somatória, com as classes de qualidade apresentada na Tabela IV. 
Tabela IV. Classificação de qualidade da água conforme o BMWP.

\begin{tabular}{|c|c|c|c|}
\hline Classe & Faixa & Qualidade da água & $\begin{array}{c}\text { Cor indicativa } \\
\text { (Padrão) }\end{array}$ \\
\hline 1 & $80-61$ & Excelente & \\
\hline 2 & $60-41$ & Boa & \\
\hline 3 & $40-26$ & Ruim & \\
\hline 4 & $\leq 25$ & Péssima & \\
\hline 5 & & & \\
\hline
\end{tabular}

\subsection{3 Índice de similaridade}

O Modelo de Porcentagem de Similaridade desenvolvido por NOVAK \& BODE (1992) baseia-se na comparação das comunidades objeto de estudo com uma comunidade considerada ideal para uma região. O modelo estabelece a participação relativa de 7 grupos de macroinvertebrados (Chironomidae, Trichoptera, Ephemeroptera, Plecoptera, Coleoptera, Oligochaeta e outros) e a afinidade ao modelo é medida usando-se a Porcentagem de Similaridade (PSc), (WHITTAKER \& FAIRBANKS, 1958).

$\mathrm{PSc}=100-0.5 \sum|\mathrm{a}-\mathrm{b}|$

Onde: a é a porcentagem de individuos do táxon $\mathrm{A}$ e b é a porcentagem do mesmo táxon na amostra B

A avaliação da qualidade da água é feita comparando-se os valores de similaridade com as classes de qualidade apresentadas na Tabela V. 
Tabela V. Valores indicativos de Porcentagem de Similaridade (PSc) e sua respectiva classe de qualidade de água.

\begin{tabular}{|c|c|c|}
\hline PSc (\%) & Qualidade de Água & Cor indicativa \\
\hline$>64$ & Não Poluída & \\
\hline $50-64$ & Ligeiramente Poluída \\
\hline $35-49$ & Moderadamente Poluída \\
\hline$<35$ & Fortemente Poluída & \\
\hline
\end{tabular}

\subsection{RESULTADOS}

\subsubsection{Estrutura taxonômica}

Nos dois períodos de estudo foram coletados, na bacia do Alto Jacaré-Guaçu, 941 exemplares de macroinvertebrados aquáticos pertencentes a 73 táxons de 43 famílias, sendo 33 de Insecta, 3 de Oligochaeta, 1 de Hirudinea, 3 de Hydracarina, 2 de Gastropoda e 1 de Crustácea (Tabelas VI, VII e VIII).

As classes de dominância dos diferentes táxons nos dois períodos climáticos são apresentadas na Tabela IX (anexo). Na Tabela $X$ estão registrados os táxons eudominantes $(>10)$ e o número total de táxons nos vários pontos amostrados da bacia hidrográfica, nos períodos das chuvas e de estiagem de 1999. De modo geral, foram coletados mais indivíduos no período de estiagem do que no período das chuvas em todos os pontos de amostragem, exceto no ponto F4, que apresentou maior número de exemplares no período chuvoso. 
Tabela VI. Famílias de insetos aquáticos coletados na bacia do Alto Jacaré-Guaçu nos períodos de estiagem e chuva de 1999.

\begin{tabular}{|c|c|c|c|}
\hline \multirow[t]{2}{*}{ Ordem } & \multirow[t]{2}{*}{ Família } & \multicolumn{2}{|c|}{ Número de Indivíduos } \\
\hline & & chuvas & estiagem \\
\hline \multirow[t]{3}{*}{ Ephemeroptera } & Baetidae & 9 & 7 \\
\hline & Caenidae & & 1 \\
\hline & Leptohyphidae & 1 & 1 \\
\hline \multirow[t]{5}{*}{ Odonata } & Calopterygidae & 7 & 7 \\
\hline & Coenagrionidae & 10 & 34 \\
\hline & Gomphidae & 3 & 37 \\
\hline & Libellulidae & 3 & 17 \\
\hline & Megapodagrionidae & 1 & \\
\hline Plecoptera & Grypopterygidae & & 1 \\
\hline \multirow[t]{5}{*}{ Hemiptera } & Corixidae & 9 & \\
\hline & Naucoridae & 6 & 2 \\
\hline & Notonectidae & 1 & 1 \\
\hline & Veliidae & 1 & 51 \\
\hline & Pleidae & 4 & 1 \\
\hline \multirow[t]{7}{*}{ Coleoptera } & Curculionidae & 1 & \\
\hline & Dryopidae & & 1 \\
\hline & Dytiscidae & & 4 \\
\hline & Elmidae & & 5 \\
\hline & Hydrophilidae & 1 & 2 \\
\hline & Notoridae & 3 & 2 \\
\hline & Syrtidae & & 1 \\
\hline \multirow[t]{5}{*}{ Trichoptera } & Hydropsychidae & & 1 \\
\hline & Hydroptilidae & 1 & 1 \\
\hline & Leptoceridae & 3 & 17 \\
\hline & Odontoceridae & 2 & 2 \\
\hline & Polycentropodidae & & 5 \\
\hline Lepidoptera & Pyralidae & 1 & \\
\hline \multirow[t]{6}{*}{ Diptera } & Ceratopogonidae & 1 & 5 \\
\hline & Chironomidae & 59 & 449 \\
\hline & Culicidae & 3 & \\
\hline & Dixidae & & 2 \\
\hline & Simuliidae & 1 & 1 \\
\hline & Tipulidae & 2 & 2 \\
\hline
\end{tabular}


Tabela VII. Gêneros de Chironomidae (Diptera) coletados na bacia do Alto Jacaré-Guaçu nos períodos de estiagem e chuva de 1999.

\begin{tabular}{|c|c|c|c|c|}
\hline \multirow{2}{*}{$\begin{array}{l}\text { Subfamília } \\
\text { Tanypodinae }\end{array}$} & \multirow{2}{*}{$\begin{array}{l}\text { Tribo } \\
\text { Coelotanypodini }\end{array}$} & \multirow{2}{*}{$\begin{array}{l}\text { Gênero - sp } \\
\text { Clinotanypus }\end{array}$} & \multicolumn{2}{|c|}{$\begin{array}{l}\text { No de Indivíduos } \\
\text { chuvas estiagem }\end{array}$} \\
\hline & & & & 3 \\
\hline & Macropelopiini & Fittkauimyia & & 2 \\
\hline & Pentaneurini & Ablabesmyia & 1 & 19 \\
\hline & & Labrundinia & 1 & \\
\hline & & Larsia & 5 & 18 \\
\hline & & Pentaneura (?) & 1 & \\
\hline & Procladiini & Djalmabatista & & 6 \\
\hline & & Procladius & & 1 \\
\hline \multirow[t]{18}{*}{ Chironominae } & Chironomini & Apedilum & & 1 \\
\hline & & Chironomus gr. decorus & 41 & 244 \\
\hline & & Cryptochironomus & 5 & 15 \\
\hline & & Endotribelos & 2 & \\
\hline & & Goeldichironomus holoprasinus & 1 & \\
\hline & & Harnischia & & 2 \\
\hline & & Prox. Harnischia & & 11 \\
\hline & & Nilothauma & & 1 \\
\hline & & Parachironomus & & 8 \\
\hline & & Paratendipes & & 1 \\
\hline & & Polypedilum (Polypedilum) & 1 & 14 \\
\hline & & Polypedilum (Tripodura) & 1 & 25 \\
\hline & & Saetheria (?) & & 1 \\
\hline & Tanytarsini & Nimbocera & & 1 \\
\hline & & Rheotanytarsus & & 3 \\
\hline & & Stempellinella & & 1 \\
\hline & & Tanytarsus & 2 & 5 \\
\hline & & Tanytarsini Gênero B & & 3 \\
\hline \multirow[t]{5}{*}{ Orthocladinae } & Corynoneurini & Thienemanniella & & 3 \\
\hline & Metriocnemini & Parametriocnemus & & 3 \\
\hline & Orthocladiini & Cricotopus & & 22 \\
\hline & & Lopescladius & & 7 \\
\hline & & Paracladius & & 28 \\
\hline
\end{tabular}


Tabela VIII. Outros macroinvertebrados aquáticos coletados na bacia do Alto Jacaré-Guaçu nos períodos de estiagem e chuva de 1999.

\begin{tabular}{|c|c|c|c|c|}
\hline Classe & Família & Gênero - sp & $\begin{array}{l}\text { No de In } \\
\text { chuvas }\end{array}$ & $\begin{array}{l}\text { ivíduos } \\
\text { estiagem }\end{array}$ \\
\hline \multirow[t]{5}{*}{ OLIGOCHAETA } & Alluroididae & Brinkhurstia americanus & 3 & 3 \\
\hline & Naididae & Allonais paraguayensis & 1 & \\
\hline & & Dero (Aulophorus) sp & & 11 \\
\hline & & Pristina sp & & \\
\hline & Tubificidae & Limnodrilus hoffmeisteri & 2 & 35 \\
\hline HIRUDINEA & Glossiphoniidae & & 1 & 30 \\
\hline \multirow[t]{3}{*}{ HIDRACARINA } & Arrenuridae & & 1 & \\
\hline & Hygrobatidae & & 1 & \\
\hline & Lymnessiidae & & 13 & 13 \\
\hline \multirow[t]{2}{*}{ GASTROPODA } & Lymnaeidae & & 1 & \\
\hline & Physidae & & & 6 \\
\hline CRUSTACEA & Palaemonidae & Macrobrachium sp. & 20 & 6 \\
\hline
\end{tabular}


Tabela X. Número de táxons e táxons eudominantes (>10) nos pontos amostrados da bacia hidrográfica do Alto Jacaré-Guaçu, nos períodos de chuva e de estiagem de 1999.

\begin{tabular}{|c|c|c|c|}
\hline $\begin{array}{c}\text { Ponto de } \\
\text { amostragem }\end{array}$ & Período & $\begin{array}{l}\text { Número de } \\
\text { táxons }\end{array}$ & $\begin{array}{l}\text { Táxons eudominantes } \\
\qquad(>10 \%)\end{array}$ \\
\hline M1 & Chuva & 7 & Larsia, Naucoridae, Baetidae, Tipulidae. \\
\hline M1 & Estiagem & 12 & $\begin{array}{l}\text { Libellulidae, Larsia, } \\
\text { hoffmeisteri, Notoridae. }\end{array}$ \\
\hline M2 & Chuva & 6 & $\begin{array}{l}\text { Corixidae, Chironomus gr. decorus, } \\
\text { Naucoridae. }\end{array}$ \\
\hline M2 & Estiagem & 10 & $\begin{array}{l}\text { Chironomus gr. decorus, Libellulidae, } \\
\text { Larsia, Cryptochironomus. }\end{array}$ \\
\hline M3 & Estiagem & 1 & Chironomus gr. decorus. \\
\hline M4 & Estiagem & 4 & $\begin{array}{l}\text { Chironomus gr. decorus, Limnodrilus } \\
\text { hoffmeisteri. }\end{array}$ \\
\hline M5 & Chuva & & \\
\hline M5 & Estiagem & 5 & Chironomus gr. decorus, Glossiphoniidae. \\
\hline $\mathrm{F} 1$ & Chuva & 18 & Chironomus gr. decorus. \\
\hline $\mathrm{F} 1$ & Estiagem & 19 & Gomphidae, Larsia. \\
\hline $\mathrm{F} 2$ & Chuva & 10 & $\begin{array}{l}\text { Baetidae, Coenagrionidae, Calopterygidae, } \\
\text { Cryptochironomus, Lymnesiidae. }\end{array}$ \\
\hline $\mathrm{F} 2$ & Estiagem & 15 & $\begin{array}{l}\text { Cryptochironomus, Chironomus gr. decorus, } \\
\text { Elmidae. }\end{array}$ \\
\hline F3 & Chuva & 5 & Lymnesiidae, Gomphidae, Pleidae. \\
\hline F3 & Estiagem & 11 & Polypedilum (Tripodura), Lymnesiidae. \\
\hline $\mathrm{F} 4$ & Chuva & 9 & Coenagrionidae, Calopterygidae. \\
\hline $\mathrm{F} 4$ & Estiagem & 3 & $\begin{array}{l}\text { Cricotopus, Brinkhurtia americanus, } \\
\text { Hydropsychidae. }\end{array}$ \\
\hline F5 & Chuva & 8 & Libellulidae, Notoridae. \\
\hline F5 & Estiagem & 17 & $\begin{array}{l}\text { Polypedilum (Polypedilum), Prox. Harnischia, } \\
\text { Leptoceridae. }\end{array}$ \\
\hline $\mathrm{J} 1$ & Estiagem & 5 & Gomphidae, Cricotopus, Paracladius \\
\hline J2 & Estiagem & 21 & Veliidae, Chironomus gr. decorus. \\
\hline J3 & Estiagem & 9 & Coenagrionidae. \\
\hline $\mathrm{J} 4$ & Estiagem & 5 & $\begin{array}{l}\text { Cricotopus, Paracladius, Thienemanhiella, } \\
\text { Brinkhurtia americanus, Polycentropodidae. }\end{array}$ \\
\hline
\end{tabular}

No ponto M1 foram identificados 7 táxons no período chuvoso e 12 na estiagem: Larsia (33\%), Naucoridae (20\%), Baetidae $(13,3 \%)$ e Tipulidae $(13,3 \%)$ foram eudominantes no período chuvoso e Libellulidae (22,2\%), Larsia (22,2\%), Limnodrilus hoffmeisteri $(22,2 \%)$ e Notoridae $(11,1 \%)$ na estiagem. 
No ponto M2 foram identificados 6 táxons no período chuvoso, sendo eudominantes Corixidae (40,9\%), Chironomus gr. decorus $(31,8 \%)$ e Naucoridae (13,6\%). No período de estiagem, dos 10 táxons identificados, Chironomus gr. decorus (31\%), Libellulidae (13,8\%), Larsia (10,3\%) e Cryptochironomus (10,3\%) foram eudominantes.

Nos pontos M3 e M4, amostrados só na época de estiagem, Chironomus gr. decorus foi o único táxon presente no ponto M3 e eudominante (65,9\%), juntamente com Limnodrilus hoffmeisteri $(24,4 \%)$, no ponto M4.

No ponto M5 não foram obtidos exemplares no período chuvoso. Na estiagem, dos 5 táxons coletados, Chironomus gr. decorus $(70,4 \%)$ e Glossiphoniidae $(23,2 \%)$ foram eudominantes.

No ponto F1 coletaram-se 18 táxons no período de precipitação, sendo eudominante Chironomus gr. decorus $(61,1 \%)$. Na estiagem dos 19 táxons identificados, Gomphidae (34\%) e Larsia (12\%) foram eudominantes.

No ponto F2, foram coletados 10 e 15 táxons nas épocas de maior precipitação e estiagem, respectivamente, sendo eudominantes, no chuvoso, Baetidae (18,8\%), Coenagrionidae (18,8\%), Calopterygidae (15,6\%), Cryptochironomus (12,5\%) e Lymnesiidae (12,5\%). Na estiagem, além de Cryptochironomus $(21,4 \%)$, foram eudominantes Chironomus gr. decorus e Elmidae, ambos com a mesma participação (10,7\%).

O ponto F3 apresentou 5 táxons no período das chuvas e 11 no período de estiagem, sendo eudominantes Lymnesiidae (53,9\%), Gomphidae $(15,4 \%)$ e Pleidae $(15,4 \%)$ no período chuvoso e, na estiagem, Polypedilum (Tripodura) com 56,1\% e Lymnesiidae com $14,6 \%$.

No ponto F4 houve maior número de táxons na época das chuvas (9), sendo Coenagrionidae $(30,8 \%)$ e Calopterygidae $(15,4 \%)$ eudominantes; Pentaneura (50\%), Cricotopus, Brinkhurtia americanus e Hydropsychidae foram os táxons coletados na estiagem. 
No ponto F5 foram identificados 8 táxons no período das chuvas, sendo eudominantes Libellulidae e Notoridae, cada um contribuindo com $20 \%$ da fauna. No período de estiagem foram identificados 17 táxons, dos quais Polypedilum (Polypedilum) (22,2\%), prox. Harnischia (14,3\%) e Leptoceridae $(12,7 \%)$ foram eudominantes.

Os pontos J1 (15 táxons), J2 (21 táxons), J3 (9 táxons) e J4 (5 táxons), que só foram amostrados no período de estiagem, apresentaram os seguintes táxons eudominantes: Gomphidae (52,9\%), Cricotopus (23,5\%), Paracladius (11,8\%), no ponto J1; Veliidae (44,4\%) e Chironomus gr. decorus (12,2\%), em J2; Coenagrionidae (53,3\%) em J3; Cricotopus (28,6\%), Paracladius (28,6\%), Thienemanhiella (14,3\%), Brinkhurtia americanus (14,3\%) e Polycentropodidae $(14,3 \%)$ no ponto J4.

Os gêneros mais representativos da família Chironomidae foram Chironomus gr. decorus, Larsia e Cricotopus, tendo sido eudominantes respectivamente em oito, quatro e três localidades.

\subsection{2 Índices comunitários}

Os índices de diversidade de Margalef $\left(\mathrm{I}_{\mathrm{Mg}}\right)$ foram mais elevados no período de estiagem. Em ambos os períodos os valores foram mais elevados nos locais próximos às nascentes e mais baixos após a área urbana (Tabela XI). O indice de diversidade de Shannon (H') apresentou valores mais elevados no período de estiagem, exceto no ponto F4. Os maiores valores foram obtidos nas nascentes M1 $(2,35)$ e F1 $(2,41)$, nas áreas de captação de água M2 $(2,08)$ e F5 $(2,47)$ e nos pontos F2 $(2,52)$ e J2 $(2,18)$. Os pontos após a área urbana foram os que apresentaram valores mais baixos (M3 =0, M4 =0,87 e M5 =0,82). Na Tabela IX estão indicados os valores obtidos nos vários pontos de coleta da bacia do Alto Jacaré-Guaçu, nos dois períodos estudados. Os valores do índice de equitatividade tiveram o mesmo padrão da diversidade (Shannon), variando entre 0 e 0,6 (Tabela XI). 
Tabela XI. Valores dos índices de diversidade (Shannon), Equitatividade (Pielou), Riqueza e Dominância (McNaughton), no período chuvoso (Ch) e de estiagem (Es) de 1999, na bacia do Alto Jacaré-Guaçu.

\begin{tabular}{|c|c|c|c|c|c|c|}
\hline $\begin{array}{c}\text { Ponto de } \\
\text { Amostragem }\end{array}$ & Período & $\begin{array}{l}\text { Diversidade } \\
\text { (Margalef) }\end{array}$ & $\begin{array}{l}\text { Diversidade } \\
\text { (Shannon) }\end{array}$ & $\begin{array}{c}\text { Equitatividade } \\
\text { (Pielou) }\end{array}$ & Riqueza & $\begin{array}{c}\text { Dominância } \\
\text { (McNaughton] }\end{array}$ \\
\hline M1 & (Ch) & 2,22 & 1,77 & 0,41 & 7 & 0,53 \\
\hline M1 & (Es) & 3,81 & 2,35 & 0,55 & 12 & $*$ \\
\hline M2 & (Ch) & 1,62 & 1,42 & 0,33 & 6 & 0,73 \\
\hline M2 & (Es) & 2,67 & 2,08 & 0,48 & 10 & 0,45 \\
\hline M3 & (Es) & 0 & 0 & 0 & 1 & 1,00 \\
\hline M4 & (Es) & 0,62 & 0,87 & 0,20 & 4 & 0,90 \\
\hline M5 & (Ch) & $*$ & $*$ & $*$ & $*$ & $*$ \\
\hline M5 & (Es) & 0,83 & 0,82 & 0,19 & 5 & 0,94 \\
\hline $\mathrm{F} 1$ & (Ch) & 3,98 & 1,78 & 0,41 & 18 & 0,74 \\
\hline $\mathrm{F} 1$ & (Es) & 4,23 & 2,41 & 0,56 & 19 & 0,44 \\
\hline $\mathrm{F} 2$ & (Ch) & 2,60 & 2,11 & 0,49 & 10 & 0,38 \\
\hline $\mathrm{F} 2$ & (Es) & 4,20 & 2,52 & 0,58 & 15 & $*$ \\
\hline F3 & (Ch) & 1,56 & 1,30 & 0,30 & 5 & $*$ \\
\hline F3 & (Es) & 2,69 & 1,58 & 0,37 & 11 & 0,71 \\
\hline $\mathrm{F} 4$ & (Ch) & 3,12 & 2,03 & 0,47 & 9 & 0,46 \\
\hline $\mathrm{F} 4$ & (Es) & 1,82 & 1,10 & 0,26 & 3 & $*$ \\
\hline F5 & (Ch) & 3,04 & 2,03 & 0,47 & 8 & 0,40 \\
\hline F5 & (Es) & 3,74 & 2,47 & 0,57 & 17 & 0,33 \\
\hline $\mathrm{J} 1$ & (Es) & 1,41 & 1,26 & 0,29 & 5 & 0,76 \\
\hline $\mathrm{J} 2$ & (Es) & 4,15 & 2,18 & 0,51 & 21 & 0,52 \\
\hline J3 & (Es) & 1,93 & 1,59 & 0,37 & 9 & 0,63 \\
\hline J4 & (Es) & 2,06 & 1,55 & 0,36 & 5 & 0,57 \\
\hline
\end{tabular}

*Não foram calculados por problemas na metodologia

O índice de dominância de McNaughton apresentou valores inversos aos da diversidade. Os menores valores foram obtidos nos pontos junto às nascentes $(\mathrm{F} 1=0,44)$ e nos pontos de captação $(\mathrm{M} 2=0,45$ e $\mathrm{F} 5=0,33)$. Os maiores índices ocorreram nos pontos após a área urbana $(\mathrm{M} 3=1,0, \mathrm{M} 4=0,90$ e $\mathrm{M} 5=0,94)$, conforme apresentado na Tabela XI. 


\subsection{3 Índices bióticos}

O Índice Biótico Belga (IBB), para o período chuvoso e seco de 1999, na bacia do Alto Jacaré-Guaçu, estão indicados na Figura 1. O IBB apontou a bacia, no período chuvoso, como de qualidade boa em 2 pontos (F1 e F2), regular em 4 (M1, M2, F4 e F5), ruim em 1 (F3) e péssima em 1 (M5). Já no período de estiagem, o IBB indicou qualidade excelente em 2 pontos (F1 e F5), boa em 3 (M1, F2 e J2), regular em 5 (M2, F3, F4, J3 e J4), ruim em 3 (M4, M5 e J1) e péssima em 1 (M3).

O Índice Biótico BMWP, para os períodos chuvoso e seco de 1999, na bacia do Alto Jacaré-Guaçu, estão indicados na Figura 2. O índice, no período das chuvas, apontou qualidade regular em 2 pontos (F2 e F4), ruim em 3 (F1, F3 e F5) e péssima em 2 (M1 e M2). No período de estiagem a qualidade da água foi excelente em 1 ponto (F1), regular em 4 (M1, F2, F3 e J3), ruim em 3 (M2, F5 e J2) e péssima em 6 (M3, M4, M5, F4, J1 e J4).

\subsubsection{Porcentagem de similaridade}

Para o cálculo da porcentagem de similaridade considerou-se a estrutura da comunidade do ponto F1, no período de estiagem, como comunidade modelo, com as seguintes participações: Oligochaeta $(0 \%)$, Ephemeroptera (10\%), Plecoptera (2\%), Coleoptera (5\%), Trichoptera (3\%), Chironomidae (29\%) e outros (51\%). A classificação da qualidade biológica da água dos pontos amostrados nos períodos de chuvas e de estiagem, de acordo com o modelo é apresentada na Figura 3.

$\mathrm{Na}$ época das chuvas observou-se a seguinte classificação: locais não poluídos (M1, M2, F1, F2 e F4) e locais ligeiramente poluídos (F3 e F5).

$\mathrm{Na}$ estiagem: locais não poluídos (F1, J1, J2 e M1), locais ligeiramente poluídos (F2, F3, M2 e J3), locais moderadamente poluídos (F5) e locais fortemente poluídos (F4, J4, M5, M3 e M4). 


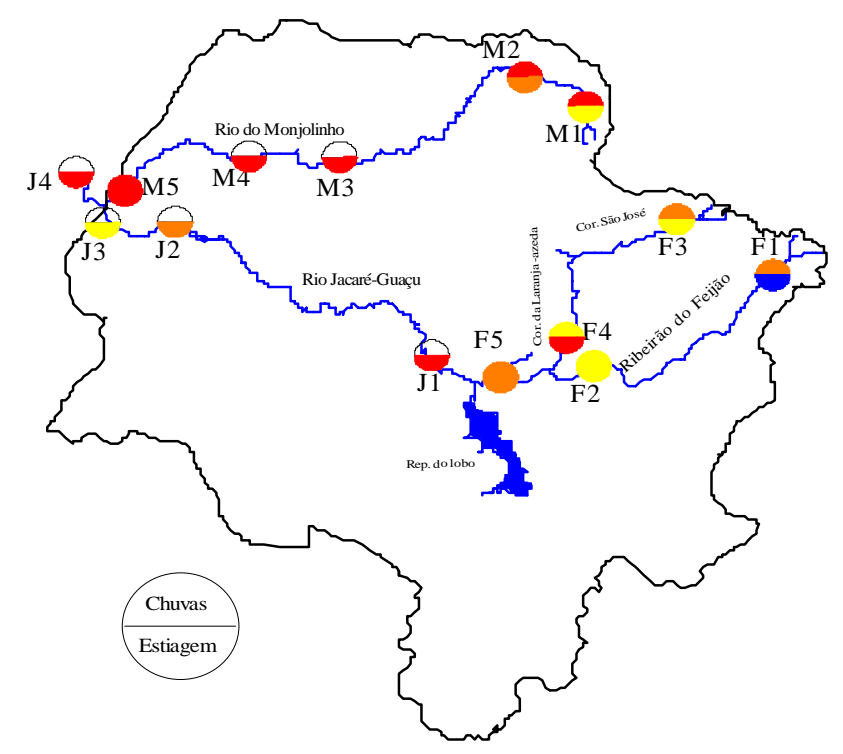

\section{Gualidade da água}

$\square \quad$ Água não Poluída

$\square$ Ligeiramente Poluída

$\square$ Moderadamente Poluída

$\square \quad$ Muito Poluída

$\square$ Fortemente Poluída

Figura 1. Mapa da qualidade da água, da bacia hidrográfica do Alto Jacaré-Guaçu, classificada para o período de estudo segundo o IBB. 


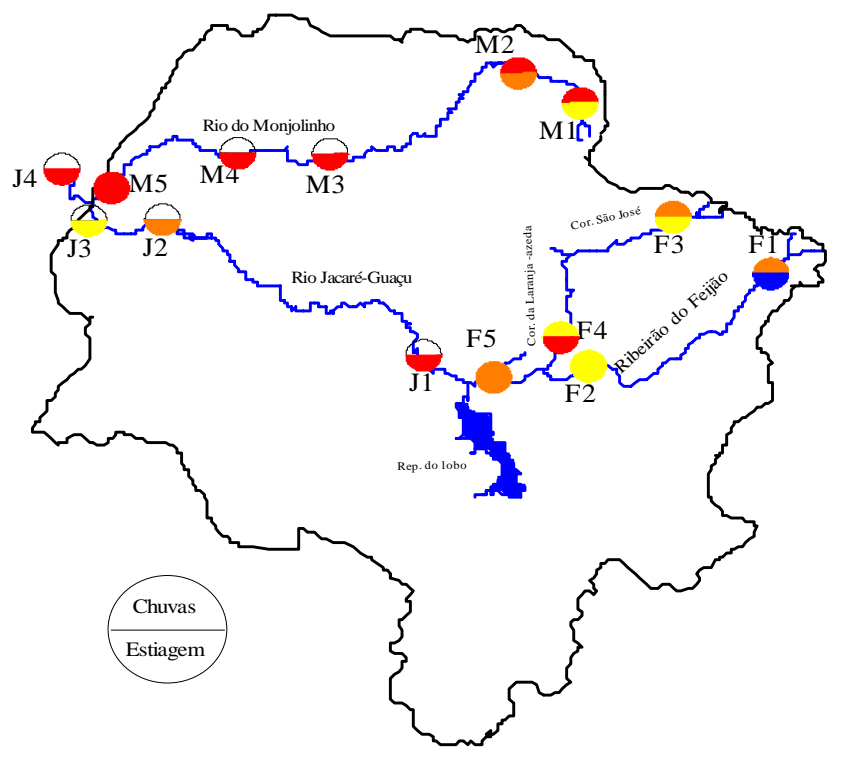

\section{Qualidade da água}

$\square$ Excelente

$\square \quad$ Boa

$\square \quad$ Regular

$\square$ Ruim

$\square \quad$ Péssima

Figura 2. Mapa da qualidade da água, da bacia hidrográfica do Alto Jacaré-Guaçu, classificada para o período de estudo segundo o BMWP. 


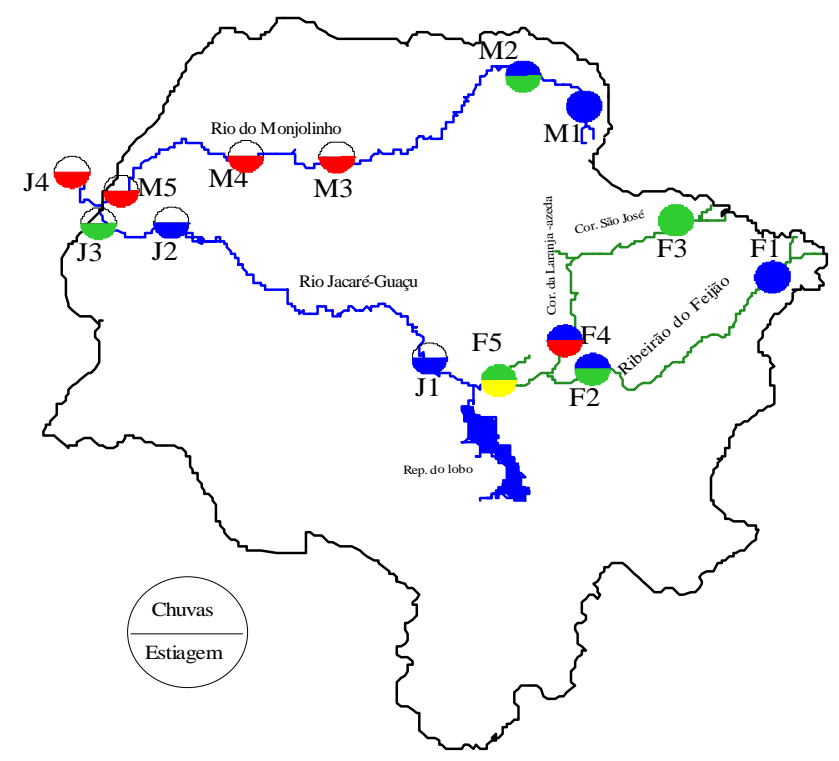

\section{Qualidade da água}

$\square \quad$ Água não Poluída

Ligeiramente Poluída

Moderadamente Poluída

Fortemente Poluída

Figura 3. Mapa da qualidade da água, da bacia hidrográfica do Alto Jacaré-Guaçu, classificada para o período de estudo segundo o Modelo de Porcentagem Similaridade 


\subsection{DISCUSSÃO}

A comunidade macrobentônica dos rios analisados apresentou uma estrutura onde os representantes da família Chironomidae dominaram espacialmente e numericamente, estando presente praticamente em todos os pontos amostrados e contribuindo com aproximadamente $54 \%$ da fauna coletada. A supremacia dos representantes dessa família parece ser uma característica dos rios e córregos da região, já tendo sido registrada em vários trabalhos (NASCIMENTO, 2000; FREIER, 2000; ROQUE, 2001).

Segundo SAETHER, (1979) a família Chironomidae, como um todo, apresenta baixo valor indicativo devido à grande variedade de táxons que possui. Alguns gêneros, porém, são característicos de ambientes com baixa carga orgânica, como, por exemplo, Lopescladius que esteve presente em locais não impactados (F1 e F2) ou ligeiramente impactados (F5 e J1). Outros gêneros, como por exemplo, Chironomus, são altamente tolerantes à poluição orgânica, sendo em determinados ambientes altamente impactados os únicos representantes da família. Este foi o caso do ponto M3, localizado imediatamente após a área urbana, onde a sua presença isolada é altamente indicativa do grau de perturbação local. Este gênero também se apresentou com elevada participação (>65\%) em duas outras localidades (M4 e M5) do Rio do Monjolinho, após a área urbana.

Um gênero cuja presença parece estar relacionada à atividade agropecuária é Larsia, dominante em algumas localidades aparentemente livres de poluição orgânica urbana, mas próximas de fazendas e assentamentos rurais. Situação semelhante foi observada por Nascimento (2000), no Córrego do Barrinha em Pirassununga.

Além disso, a presença ou a dominância de determinados gêneros pode ser indicativa das características físicas e hidrológicas do sistema. Um bom exemplo disso é a restrição dos representantes 
da subfamília Orthocladiinae nas sub-bacias do Ribeirão do Feijão e do Rio Jacaré-Guaçu, que se caracterizam por apresentarem águas mais rápidas do que a sub-bacia do Rio do Monjolinho.

Entre os outros macroinvertebrados de particular importância na caracterização dos sistemas e detecção de possíveis impactos estão os Plecoptera e Annelida. Os primeiros, representados por uma única família (Grypopterygidae) que, segundo ROLDAN (1988), é indicador de águas não poluídas, foi observado apenas no ponto $\mathrm{F} 1$, confirmando a qualidade do local. A dominância de Limnodrilus hoffmeisteri, juntamente com Chironomus no ponto (M4), junto à usina da Serra, indica o grau de comprometimento local, decorrente da elevada carga orgânica e de nutrientes provenientes, além do esgoto urbano, das atividades relacionadas à cultura de cana-deaçúcar. O local a jusante deste ponto (M5) apresentou significativa dominância de Hirudinea (Glossiphoniidae), que parece indicar uma discreta recuperação no curso da água, confirmada pela análise dos componentes principais (Capítulo 3).

Os resultados faunísticos aqui obtidos foram semelhantes aos obtidos por GUERESCHI (1995) na sub-bacia do Rio do Monjolinho. Houve coincidência na dominância de Chironomus, Oligochaeta e Hirudinea. Na sub-bacia do Ribeirão do Feijão, TEIXEIRA (1993) encontrou como táxons eudominantes, Chironomidae, Elmidae e Gomphidae, que também dominaram nas mesmas localidades no presente estudo.

Segundo WASHINGTON (1984), os índices de diversidade não podem ser utilizados como única medida, "varinha mágica", em avaliações de poluição de água. Porém, devem ser considerados como ferramentas complementares importantes na avaliação da poluição, não sendo recomendada a sua utilização isolada.

Em geral, no sistema analisado, os maiores valores de diversidade, dos dois índices aplicados, foram registrados no período de estiagem. Os valores mais baixos obtidos no período das chuvas, 
possivelmente decorram, em parte, do aumento do fluxo de água que resulta na deriva da fauna, principalmente nos locais com baixa cobertura vegetal. Na época das chuvas o menor valor foi observado no ponto M5 que, possivelmente, devido a erros de amostragem não apresentou macroinvertebrados e, conseqüentemente, o resultado dos índices foi zero. Os maiores índices foram observados nos pontos F1 e F2. A presença de margens protegidas por mata ciliar (F2) e o fundo pedregoso e arenoso ( $\mathrm{F} 1$ e F2) possivelmente fornecem uma maior variedade de microhabitats para os organismos bentônicos. Os menores valores de diversidade foram registrados após à área urbana $(<1)$, confirmando, desta maneira, o impacto da poluição orgânica, procedente de esgotos urbanos sem tratamento da cidade de São Carlos e dos efluentes da agroindústria da cana-de-açúcar.

WILHM apud WASHINGTON (1984) sugere a seguinte classificação das águas segundo o índice de Shannon:

- $\mathrm{H}=3$ - 5 águas limpas;

- $\mathrm{H}=1$ - 3 águas moderadamente poluídas;

- $\mathrm{H}<1$ águas altamente poluídas.

De acordo com essa classificação, a bacia do Alto JacaréGuaçu não apresenta águas limpas, podendo ser enquadradas como moderadamente poluídas, nos pontos sem influência urbana, e altamente poluídas, nos pontos à jusante da cidade de São Carlos.

Situação semelhante foi obtida utilizando-se o índice de dominância de McNaughton, que apresentou os valores mais elevados $(>0,90)$ nos locais mais poluídos.

Dos índices bióticos aplicados à comunidade de macroinvertebrados bentônicos, o IBB foi o que melhor caracterizou a qualidade da água da bacia do Alto Jacaré-Guaçu. O índice BMWP não apresentou resultados satisfatórios, provavelmente devido à pobreza faunística da bacia hidrográfica, que é característica de sistemas lóticos com leitos predominantemente arenosos, como é o caso da bacia em questão. Possivelmente esta baixa diversidade de 
grupos seja uma característica dos rios que percorrem zonas de cerrado (TRIVINHO-STRIXINO \& NASCIMENTO, 2000). Este fato pode ser considerado como um dos inconvenientes na aplicação deste indice, pois o mesmo depende muito da riqueza faunística da área amostrada.

Embora sejam promissoras as expectativas sobre a utilização de índices biológicos de qualidade da água, o conhecimento taxonômico da maioria dos grupos de macroinvertebrados ainda é deficiente; alguns grupos foram identificados apenas até o nível de família devido à ausência de chaves regionais. Além disso, a importação desses índices, criados para países do hemisfério norte com clima totalmente diverso e com rios estruturalmente diferentes, para nossa região deve ser feita com o devido cuidado, pois muitos macroinvertebrados que constam nas tabelas de classificação de tolerâncias não fazem parte de nossa fauna; ao contrário, outros macroinvertebrados são característicos apenas de nossa fauna.

São necessários, além disso, a padronização da metodologia de coleta, um maior número de amostragens em locais com características ambientais diferenciadas e readaptações das tabelas de tolerância para que se tenha um uso mais confiável desses índices bióticos.

A aplicação do modelo de porcentagem de similaridade mostrou resultados mais de acordo com as propriedades físicas e químicas da água (Capítulo 3) e com o conhecimento prévio da bacia. Embora tenha se elegido a comunidade do ponto F1 como modelo, pela sua composição taxonômica, maior diversidade, alta riqueza, alta equitatividade, baixa dominância e boa qualidade de água pelos indices bióticos, são necessárias mais informações sobre o local e um maior número de amostragens para ter dados mais confiáveis, e poder implementar este modelo em programas de biomonitoramento na bacia. 


\section{CONCLUSÕES}

De uma maneira geral, através dos resultados obtidos das características físicas e químicas da água e análise da comunidade de macroinvertebrados, pode-se inferir que:

- Segundo os valores das variáveis físicas e químicas e da análise através do ACP, a qualidade da água dos pontos de amostragem em que se dividiu a bacia hidrográfica do Alto Jacaré-Guaçu, no presente estudo, podem ser classificados em 3 grupos:

- Sem influência urbana (M1, M2, F1, F2, F3, F4, F5, J1, J2, J3), sendo não poluída a ligeiramente poluída;

- Com influência da área urbana da Cidade de São Carlos (M3 e M4), sendo fortemente poluída;

- A jusante desses dois últimos pontos (M3 e M4), no ponto M5, com uma poluição moderada, indicando sinais de recuperação. Esta classificação é corroborada pela composição dos macroinvertebrados presentes nos diferentes pontos.

- A dominância de Limnodrilus hoffmeisteri (Annelida-Oligochaeta), juntamente com Chironomus (Insecta-Diptera) no Rio do Monjolinho, junto à usina da Serra (M4), indica o grau de comprometimento local decorrente da elevada carga orgânica e de nutrientes provenientes do esgoto urbano e das atividades relacionadas à cultura de cana-de-açúcar. 
- Dos índices bióticos aplicados à comunidade de macroinvertebrados, o Índice Biológico Belga (IBB) foi o que melhor caracterizou a qualidade da água da bacia do Alto JacaréGuaçu.

- A aplicação do Modelo de Porcentagem de Similaridade para a comunidade de macroinvertebrados mostrou resultados coerentes com as propriedades físicas e químicas da água, podendo ser implementado após um conhecimento mais apurado da fauna local, em programas de biomonitoramento.

- As concentrações dos metais analisados, em geral, apresentaramse dentro dos limites da Resolução CONAMA 20/86. Exceção é feita para o cobre e ferro no período das chuvas e no período de estiagem nas áreas localizadas após a malha urbana, para o ferro, manganês e zinco.

- Com relação à concentração de metais no sedimento, a fração biodisponivel foi alta, principalmente para chumbo (52\%) e prata (47\%), metais altamente tóxicos, o que sugere uma alta probabilidade de retorno destes metais para o compartimento água e um possível risco de toxicidade e/ou bioacumulação para a biota que se supre dela.

- A maior parte da área da bacia do Alto Jacaré-Guaçu (80\%) não atende aos Padrões da Resolução CONAMA 20/86 para os pesticidas organoclorados analisados, detectados em concentrações acima dos limites permitidos. 
- Em geral os níveis de PCBs detectados estiveram acima dos PQA da CONAMA 20/86 devido à grande persistência desses compostos no ambiente.

- No sedimento, em relação às concentrações de organoclorados detectadas, no período das chuvas verificou-se, em geral, que a quantidade $\mathrm{e}$ a diversidade foram mais elevadas quando comparadas com as detectadas na água, o que era de se esperar pelo efeito das chuvas na lixiviação do solo e, por conseguinte, aumento do material particulado (Capítulo 3), ao qual os organoclorados têm alta afinidade. Já no período de estiagem, tanto a quantidade como a diversidade dos organoclorados foi menor.

- Dos pesticidas organoclorados analisados, as concentrações de Endrin, Heptacloro e Epóxido de heptacloro foram muito altas, principalmente no período de seca, no ponto M2, onde os usos predominantes do solo são as pastagens e culturas temporárias, indicando um possível uso indiscriminado desses produtos nas lavouras na área de influência do ponto M2, local de captação (20\%) da água para abastecimento da cidade de São Carlos.

- Entre as nascentes dos rios formadores da bacia, a do Rio do Monjolinho é a que merece atenção especial e imediata, já que se encontra em estado moderado de impacto, segundo as características físicas, químicas e biológicas da água, devido às atividades agropastoris em suas margens e ausência de mata ciliar. A situação tende a piorar devido ao crescimento da área urbana da cidade nessa direção, se não se tomarem as medidas necessárias para seu controle e posterior recuperação. 
Quanto à identificação dos diferentes impactos no uso da terra e da água na bacia hidrográfica, pode-se citar, entre as atividades antrópicas que vem acelerando o processo de degradação ambiental, principalmente na qualidade da água as seguintes atividades:

- falta de tratamento do esgoto doméstico, principalmente na área urbana;

- o desmatamento contínuo levando a substituição da vegetação natural por monoculturas e pastagens;

- o uso irregular do solo causando erosão e assoreamento nos corpos de água;

- expansão sem controle da área urbana próximas as margens e principalmente nas nascentes dos corpos de água;

- falta de controle na comercialização e uso de defensivos agrícolas. 


\section{REFERÊNCIAS BIBLIOGRÁFICAS}

AIROLDI F.P. da S. (1997). Determinação de Pentaclorofenol e Hexaclorobenzeno em solo contaminado por resíduos industriais. Dissertação de Mestrado. Instituto de Guímica de São Carlos. Departamento de Físico-Química. Universidade de São Paulo.

APHA (1989). Standard methods for the examination of water and waste water. $17^{\text {th }}$ Edition. Washington, U.S.A.

ARMITAGE, P.D.; MOSS, D.; WRIGHT, J.F. \& FURSE, M.T. (1983). The performance of a new biological water quality score system based on macroinvertebrates over a wide range of unpolluted running-water sites. Water Res. v. 17 n. 3 p. 333-347.

BARRETO, A. dos S. (1999) Estudo da distribuição de metais em ambiente lótico, com ênfase na assimilação pelas comunidades biológicas e na sua quantificação no sedimento e na água. Tese de Doutorado. Escola de Engenharia de São Carlos. Universidade de São Paulo. 276p. São Carlos-SP.

BRANCO, S.M. (1991) A água e o homem. In PORTO, R.L.L.; BRANCO, S.M.; CLEARY, R.W.; COIMBRA, R.M.; EIGER, S.; LUCA, S.J. de; NOGUEIRA, V. De P.Q.; PORTO, M.F. do A. (1991). Hidrologia ambiental. Editora da Universidade de São Paulo: Associação Brasileira de Recursos Hídricos; v. 3. 414p.

BRIKHURST, R.O.; MARCHESE, M.R. (1989). Guia para la identificación de Oligoquetos acuaticos de Sud y Centroamerica. Asociación Ciencias Naturales del Litoral. Argentina. Colección Climax (5), 207p.

BRONDI, S.H.G. (2000). Determinação de multiresiduos de agrotóxicos de água de abastecimento de Araraquara (Ribeirão das Cruzes, Ribeirão das Anhumas e Córrego do Paio). Teses de Doutorado. Escola de Engenharia de São Carlos. Universidade de São Paulo. 133p. São Carlos-SP.

CÁCERES, O.; TUNDISI, J.G.; CASTELLAN, O.A.M. (1980). Resíduos de insecticidas organoclorados na Represa do Broa e nos seus rios tributários. Ciência e Cultura 32 (12). 1659-1662p. 
CALHEIROS, D.F. (1993). Ecotoxicologia de compostos organoclorados persistentes em um ecossistema eutrófico: Represa de Barra Bonita (Médio Tietê-SP). Dissertação de Mestrado. Escola de Engenharia de São Carlos. Universidade de São Paulo. 198p. São Carlos-SP.

CARLSON, R.E. (1977). A trophic state index for lakes. Limnological and Oceanography. v. 22(2). p. 361-369

CARVALHO, A. R. (1996). Avaliação da qualidade da água e da interacção entre o ecossistema aquático e o terrestre em dois afluentes do Rio Jacaré-Guaçu, na APA Corumbataí (Itirapina/SP). Dissertação de Mestrado. Escola de Engenharia de São Carlos. Universidade de São Paulo. 115p. São Carlos-SP.

CELESTE, M. de F.; CÁCERES, O. (1987). Resíduos de praguicidas clorados na represa do Ribeirão do Lobo (Broa) e nos seus rios tributários. Ciência e Cultura 39 (1). 66-70p.

COMPANHIA DE SANEAMENTO AMBIENTAL DO ESTADO DE SÃO PAULO - CETESB (1986). LEGISLAÇÃO FEDERAL - Resolução CONAMA n ${ }^{0} 20$.

CHAPMAN, D. (1992). Water quality assessment. A guide to the use of biota, sediments and water in enviromental monitoring. 1. ed. UNESCO/WHO/UNEP. Chapman \& Hall. 585p.

COMPANHIA DE SANEAMENTO AMBIENTAL DO ESTADO DE SÃO PAULO - CETESB (1996). Avaliação do Complexo Billings: comunidades aquáticas, égua e sedimento (out/92 a out/93). Relatório Técnico. 53p + anexos.

Del GRANDE, M. (2001). Determinação de compostos organoclorados, Pentaclorofenol, Hexaclorobenzeno e Bifenilas Policloradas em Água, sedimento e peixes da bacia do Rio Piracicaba/SP. Dissertação de Mestrado. Instituto de Química de São Carlos. Universidade de São Paulo. 107p. São Carlos-SP.

DE PAUW, N.; VANHOOREN, G. (1983). Method for biological quality assessment of sampling of macroinvertebrates in the assessment of water quality by the Belgian Biotic Index. Hydrobiologia 133: 153-168.

ESTEVES, F. de A. (1988). Fundamentos de limnologia. Rio de Janeiro. Interciência: FINEP. 575p. 
FERRANTE, J.T.E. (1989). Mapeamento geotécnico regional da bacia do Alto Jacaré-Guaçu-São Paulo, com base nas aplicações de técnicas de sensoriamento remoto e sistema geográfico de informação. Proposta metodológica. Dissertação de Mestrado. Escola de Engenharia de São Carlos. Universidade de São Paulo. V 1. 183p. São Carlos-SP.

FISCHER, E.G. (1995) Determinação do grau de contaminação do Ribeirão do Feijão através de levantamento de dados e modelo matemático de qualidade da água, SP Dissertação de Mestrado. Escola de Engenharia de São Carlos. Universidade de São Paulo. 136p. São Carlos-SP.

FONTOURA, A.P. (1985). Manual de vigilância da qualidade das águas superficiais. Avaliação biológica da qualidade da água. Instituto de zoologia "Dr. Augusto Nobre". Faculdade de Ciências - Universidade do Porto. Porto-Portugal. 38p.

FÖRSTNER, U.; WITTMANN, G.T.W. (1983). Metal pollution in the aquatic environment. Second Revised Edition. 486p.

FREIER, C.F. (2000). Impacto de diversos usos do solo sobre o Ribeirão Canchim (CPPSE-EMBRAPA), São Carlos-SP: Macroinvertebrados bentônicos como bioindicadores. Dissertação de Mestrado. Universidade Federal de São Carlos. 87p. São Carlos-SP.

FUNDAÇÃO CENTRO TECNOLÓGICO DE MINAS GERAIS (CETEC), (1994). Desenvolvimento de métodos e técnicas de bioindicadores de qualidade de água na bacia do Alto Rio das Velhas. Belo Horizonte. 171p. Relatório Técnico Final.

GOLTERMAN, H.L.; CLYMO, R.S.; OHNSTAD, M.A.M. (1978). IBP Handbook n. 8. Methods for physical and chemical analysis of fresh waters. 2 Ed. Blackwell Scientific Publications. Oxford. $213 \mathrm{p}$.

GUERESCHI, R.M. (1995). Monitoramento biológico da bacia hidrográfica do Rio do Monjolinho pelo uso de invertebrados bentônicos. Monografia. Universidade Federal de São Carlos. 97p. São Carlos-SP.

KANIEWSKA-PRUS, M.; KIDAWA, A. (1983). Application of some benthic indices for quality evaluation of water highly polluted with municipal sewage. Pol. Arch. Hydrobiol. v. 30(3): p. 263-269. 
FORSTNER, U.; AHLF, W.; CALMANO, W.; KERSTEN, M. (1990). Sediment criteria development. In: Sediments and Enviromental Chemistry. D. Heling et. al. (Eds.). Springer Berlin. p. 311-338.

KOROLEFF, F. (1976). Determination of nutrients. In: Methods of seawater analysis. GRASSNOF, K. (ed.), Verlag. Chemie. Weinhein: p. 117-181.

LIMA, N.R.W. (1990). Análise dos níveis de metais pesados no sistema hídrico da Estação Ecológica de Jataí, SP. Acta Limnológica Brasiliensia, v. III, Tomo 2, p.101-1021.

LIKENS, G.R.: BORMANN, F.H. (1974). Linkages between terrestrial and aquatic ecosystems. Bioscience 24: 447-456.

MACKERETH, F.J.H.; HERON, J.; TALLING, J.F. (1978). Water analysis: some revised methods for limnologists. Fresh water Biological Association. Scientific Publication 36. Titus Wilson \& Son ltd., Kendall. 117 p.

NASCIMENTO, V.M. da C. (2000). Estudo da carga de nutrientes e da comunidade bentônica do Córrego Barrinha, Pirassununga-SP. Tese de Doutorado. Universidade Federal de São Carlos. 159p. São Carlos-SP.

McCAFFERTY, W.P. (1981). Aquatic entomology: The fishermen's and ecologists illustrated guide to insects and their relatives. Boston: Jones and Bartlett Publishers. 448p.

MENDES, A.J.S. (1998). Avaliação dos impactos sobre a comunidade macrozoobentônica no Córrego do Monjolinho (São Carlos, SP). Dissertação de Mestrado. Escola de Engenharia de São Carlos. Universidade de São Paulo. 128p. São Carlos-SP.

MEYBECK, M.; HELMER R. (1992). An introduction to water quality In CHAPMAN, D. (1992) Water quality assessment. Cambridge, University Press. 585p.

MEYBECK, M. (1996). River water quality global ranges, time and space variabilities, proposal for some redefinitions. Verh. Internat. Verein. Limnol. Stuttgart. 26. 81-96p.

MINISTÉRIO DA SAÚDE (1990). Diário Oficial da União - Portaria n. 36.

MOZETO, A.A. (1999). Sedimentos e particulados lacustres: amostragens e análises biogeoquímicas. Laboratório de Biogeoquímica Ambiental - Apostila. Departamento de Química. Universidade Federal de São Carlos. 24p. São Carlos-SP. 
NAVAS-PEREIRA, D.; De PÁDUA, H.B.; EYSINK, G.G.J.; PIVABERTOLETTI S.A.E. (1985). Niveis de contaminação por metais pesados e pesticidas na água, sedimento e peixes da Represa de Barra Bonita. 21p.

NOVAK, M.A.; BODE, R.W. (1992). Percent Model Afinity: a new measure of macroinvertebrate community composition. J.N. Am. Benthol. Soc. v. 11, n. 1, p. 80-85.

OLIGOELEMENTOS ON LINE. www.oligoelementos.br

PAULA, F.C.F. de (1999). Biogeoquímica de elementos traço dos sedimentos de uma bacia de drenagem numa área nãoimpactada da costa sudeste brasileira (Ilha Grande, RG). Tese de Doutorado. Universidade Federal de São Carlos. 94p. São Carlos-SP.

PEDROSO, F.; BONETTO, C.A.; ZALOCAR, Y.A. (1988). Comparative study on phosphorus and nitrogen transport in the Parana, Paraguay and Bermejo rivers. Limnologia e Manejo de Represas. Séries: Monografias em Limnologia. São Paulo. ACIESP. v. 1, t. 1, p. 91-117.

PRADO, H.; OLIVEIRA, J.B.; ALMEIDA, C.L.F. (1981). Levantamento pedológico semi-detalhado do Estado de São Paulo. Quadricula de São Carlos. Impressão Aerofoto Cruzeiro, Rio de Janeiro. Mapa 1:100:000.

RIOS, L. (1993). Estudo limnológico e fatores ecológicos em ribeirões e córregos da bacia hidrográfica do Ribeirão do Feijão (Estado de São Paulo) Dissertação de Mestrado. Escola de Engenharia de São Carlos. Universidade de São Paulo. 146p. São Carlos-SP.

ROLDÁN-PÉREZ, G. (1988). Guía para el estudio de los macroinvertebrados acuáticos del Departamento de Antioquia. Bogotá, Colombia. Editorial Presencia Ltda. 217p.

ROQUE, F. de O. (2001). Distribuição especial dos macroinvertebrados bentônicos nos córregos do Parque Estadual do Jaraguá (SP): Considerações para a conservação ambiental. Dissertação de Mestrado. 73p. Universidade Federal de São Carlos. São Carlos-SP.

ROSE, A.W.; HAUKES, H.E.; WEBB, J.S. (1979). Geochemistry in mineral exploration. London Academic Press. p. 206-215.

SAETHER, O.A. (1979). Chironomid communities as water quality indicators. Holarctic Ecology. 2: p. 65-74. 
SALAMI. L.N.B.P. (1996). Estudo das influências climáticas e antropogênicas nas características físico-químicas no Rio Monjolinho. Dissertação de Mestrado. Escola de Engenharia de São Carlos. Universidade de São Paulo. 132p. São Carlos-SP.

SANTOS, M.F. dos (1993). Subsídios para o planejamento conservacionista da bacia hidrográfica do Ribeirão do Feijão. Dissertação de Mestrado. Escola de Engenharia de São Carlos. Universidade de São Paulo. 222p. São Carlos-SP.

SÉ, J.A.S. (1992). O Rio Monjolinho e sua bacia hidrográfica como integradores de sistemas ecológicos. Dissertação de Mestrado. Escola de Engenharia de São Carlos. Universidade de São Paulo. 392p. São Carlos-SP.

SILVA, F.J.P. de (1998). Caracterização abiótica do Ribeirão do Feijão, considerando-se dois regimes hidrológicos, chuva e seca (São Carlos- SP). Dissertação de Mestrado. Escola de Engenharia de São Carlos. Universidade de São Paulo. 184p. São Carlos-SP.

SILVÉRIO, P.F. (2000). Participação, biodisponibilidade e toxicidade de metais pesados a organismos bentônicos em sedimentos. Dissertação de Mestrado. Universidade Federal de São Carlos. 78p. São Carlos-SP.

SMITH, S.L.; MACDONALD, D.D.; KEENLEYSIDE, K.A.; GAUDET, C.L. The development and implementation of Canadian sediment Quality Guidelines. In MUNAWAR, M.; DAVE, G. (1996). Development and progress in sediment Quality Assessment: Rationale, challenges, techniques \& strategies. Ecovision World Monograph Series. p. 233-249.

STRIXINO, G.; TRIVINHO-STRIXINO, S. (1998). Povoamentos de chironomidae (Diptera) em lagos artificiais. Oecologia Brasiliensis pp. 141-154. In NESSIMIAN, J.L.; CARVALHO, A.L. (eds). Ecologia de insetos aquáticos. Series Oecologia Brasiliensis. Vol. V. PPGE-UFRJ. Rio de Janeiro, Brasil.

SUGUIO, K. (1973). Introdução à sedimentologia. São Paulo. Editora Edgard Blucher Ltda. 317p.

TEIXEIRA, D. (1993). Caracterização limnologica dos sistemas lóticos e variação temporal e espacial de invertebrados bentônicos na bacia do Ribeirão do Feijão (São Carlos/SP). Dissertação de Mestrado. Escola de Engenharia de São Carlos. Universidade de São Paulo. 193p. São Carlos-SP.

TINSLEY, I.J. (1979). Chemical concepts in pollutant behavior. 1.ed. Willey Interscience, NY. 
TOLEDO JR, A.P. de; TALARICO, M.; CHINEZ, S.J.; AGUDO, E.G. (1983). A aplicação de modelos simplificados para a avaliação do processo da eutrofização em lagos e reservatórios tropicais. In $12^{\circ}$ CONGRESSO BRASILEIRO DE ENGENHARIA SANITÁRIA E AMBIENTAL. Balneário Camboriú, Santa Catarina. DENG-22: p. $1-34$.

TONISSI, F.B. (1999). Avaliação ecotoxicológica do Reservatório de Salto Grande, Americana (SP), como subsídio para a análise da qualidade ambiental do sistema. Dissertação de Mestrado. Escola de Engenharia de São Carlos. Universidade de São Paulo. 137p. São Carlos-SP.

TRIVINHO-STRIXINO, S. \& STRIXINO, G. (1995). Larvas de Chironomidae (Diptera) do Estado de São Paulo: guia de identificação de diagnose dos gêneros. São Carlos: PPGERN/UFSCar. 229p.

TRIVINHO-STRIXINO, S. \& NASCIMENTO, V.M. (2000). Indicadores básicos de qualidade ambiental para bacias hidrográficas: macroinvertebrados bentônicos como indicadores biológicos. Curso teórico-prático sobre bioindicadores de qualidade de água. Organizado pela Embrapa meio Ambiente.

WASHINGTON, H.G. (1984). Review. Diversity, biotic and similarity indices. A review with special relevance to aquatic ecosystems. Water Res. v. 18 n. 6 p 653-694.

WHITTAKER, R.H.; FAIRBANKS, C.W. (1958). A study of plankton copepod communities in the Colombian Basins, South-eastern Washington. Ecology 39, pp46-65.

ZIOLLI, et. al., (1995). Estudo preliminar da composição da água da chuva na região de Campinas/SP. Anais da 18 ${ }^{\text {a }}$. Reunião Anual da Sociedade Brasileira de Química e $7^{0}$ Encontro Brasileiro de Fotoquímica e Fotobiologia.

ZUIN V.G. (1997). Determinação de Pentaclorofenol e Hexaclorobenzeno em águas naturais de superfície de áreas afetadas por resíduos de organoclorados. Dissertação de Mestrado. Instituto de Guímica de São Carlos. Departamento de Físico-Química. 66p. Universidade de São Paulo. 
ANEXOS 
Tabela I (Capítulo 3). Resultado das análises físicas e químicas da água realizadas nos diferentes pontos de coleta da bacia hidrográfica do alto Jacaré-Guaçu em março/99.

\begin{tabular}{|c|c|c|c|c|c|c|c|c|}
\hline Variável & M1 & $\mathrm{M} 2$ & M5 & F1 & F2 & $\mathrm{F3}$ & F4 & F5 \\
\hline $\begin{array}{l}\text { Temperatura da água }{ }^{0} \mathrm{C} \\
\mathrm{pH}\end{array}$ & $\begin{array}{c}21 \\
4,99\end{array}$ & $\begin{array}{c}24 \\
5,40\end{array}$ & $\begin{array}{c}25 \\
6,64\end{array}$ & $\begin{array}{c}21 \\
5,83\end{array}$ & $\begin{array}{c}24 \\
5,55\end{array}$ & $\begin{array}{c}23 \\
5,90\end{array}$ & $\begin{array}{c}24 \\
5,58\end{array}$ & $\begin{array}{c}24 \\
5,41\end{array}$ \\
\hline Oxigênio dissolvido $\left(\mathrm{mgL}^{-1}\right)$ & 5,84 & 5,67 & 6,46 & 8,56 & 6,62 & 6,50 & 5,99 & 6,40 \\
\hline $\begin{array}{l}\text { Condutividade }\left(\mathrm{uScm}^{-1}\right) \\
\text { Turbidez (NTU) }\end{array}$ & $\begin{array}{l}21 \\
62\end{array}$ & $\begin{array}{l}24 \\
92\end{array}$ & $\begin{array}{c}82 \\
100\end{array}$ & $\begin{array}{l}26 \\
26\end{array}$ & $\begin{array}{l}11 \\
22\end{array}$ & $\begin{array}{l}33 \\
24\end{array}$ & $\begin{array}{l}23 \\
98\end{array}$ & $\begin{array}{l}19 \\
58\end{array}$ \\
\hline Materiais suspensão totais $\left(\mathrm{mgL}^{-1}\right)$ & 17,56 & 23,15 & 38,94 & 6,90 & 12,75 & 6,28 & 68,82 & 14,82 \\
\hline Materiais suspensão inorgânicos $\left(\mathrm{mgL}^{-1}\right)$ & 12,86 & 17,04 & 30,71 & 4,38 & 7,49 & 4,68 & 59,33 & 9,15 \\
\hline Materiais em suspensão orgânicos $\left(\mathrm{mgL}^{-1}\right)$ & 4,70 & 6,11 & 8,23 & 2,52 & 5,26 & 1,60 & 9,49 & 5,67 \\
\hline Carbono dissolvido total $\left(\mathrm{mgL}^{-1}\right)$ & 2,34 & 2,88 & 6,83 & 3,47 & 1,97 & 3,34 & 3,17 & 2,42 \\
\hline Carbono dissolvido inorgânico $\left(\mathrm{mgL}^{-1}\right)$ & 1,79 & 2,65 & 5,72 & 1,78 & 0,89 & 3,21 & 1,87 & 1,36 \\
\hline Carbono dissolvido orgânico $\left(\mathrm{mgL}^{-1}\right)$ & 0,55 & 0,24 & 1,11 & 1,69 & 1,08 & 0,13 & 1,30 & 1,06 \\
\hline $\mathrm{DBO} 5\left(\mathrm{mgL}^{-1}\right)$ & 0,59 & 0,08 & 1,81 & 0,62 & 0,69 & 0,16 & 0,96 & 0,38 \\
\hline Nitrogênio Kjeldahl $\left(\mathrm{ugL}^{-1}\right)$ & 494 & 270 & 1194 & 261 & 391 & * & 643 & 429 \\
\hline Fosfato Total $\left(\mathrm{ugL}^{-1}\right)$ & 39 & 38 & 117 & 23 & 26 & * & 67 & 43 \\
\hline Íon amônio $\left(\mathrm{ugL}^{-1}\right)$ & 35 & 56 & 118 & 44 & * & 34 & 53 & 35 \\
\hline Nitrito $\left(\mathrm{ugL}^{-1}\right)$ & 4 & 3 & 61 & 5 & * & 4 & 6 & 4 \\
\hline Nitrato $\left(\mathrm{ugL}^{-1}\right)$ & 490 & 90 & 329 & 252 & * & 133 & 157 & 125 \\
\hline
\end{tabular}

* dados não analisados 
Tabela II (Capítulo 3). Resultado das análises físicas e químicas da água realizadas nos diferentes pontos de coleta da bacia hidrográfica do alto Jacaré-Guaçu em agosto/99.

\begin{tabular}{|c|c|c|c|c|c|c|c|c|c|c|c|c|c|c|}
\hline Variável/Ponto de amostragem & M1 & M2 & M3 & M4 & M5 & F1 & $\mathrm{F} 2$ & F3 & F4 & F5 & J1 & $\mathrm{J} 2$ & J3 & J4 \\
\hline Temperatura da água ${ }^{0} \mathrm{C}$ & 18 & 19 & 19 & 17 & 17 & 13 & 16 & 15 & 16 & 16 & 17 & 17 & 18 & 18 \\
\hline pH & 6,40 & 6,31 & 6,51 & 6,71 & 6,71 & 6,01 & 6,24 & 6,36 & 6,40 & 6,73 & 6,07 & 6,13 & 6,32 & 6,62 \\
\hline Oxigênio dissolvido $\left(\mathrm{mgL}^{-1}\right)$ & 8,30 & 7,79 & 8,52 & 9,43 & 6,20 & 11,57 & 9,73 & 9,26 & 9,72 & 9,65 & 9,23 & 9,48 & 9,04 & 9,08 \\
\hline Condutividade $\left(\mathrm{uScm}^{-1}\right)$ & 11 & 12 & 113 & 119 & 133 & 17 & 6 & 15 & 17 & 11 & 11 & 20 & 16 & 27 \\
\hline Turbidez (NTU) & 4 & 10 & 45 & 45 & 19 & 5 & 6 & 3 & 10 & 11 & 7 & 4 & 7 & 8 \\
\hline Materiais suspensão totais $\left(\mathrm{mgL}^{-1}\right)$ & 2,16 & 6,60 & 47,67 & 50,33 & 10,60 & 3,12 & 4,96 & 1,12 & 10,30 & 9,00 & 8,70 & 2,57 & 3,71 & 4,57 \\
\hline Materiais suspensão inorgânicos $\left(\mathrm{mgL}^{-1}\right)$ & 0,72 & 2,10 & 22,33 & 24,00 & 3,80 & 1,04 & 2,16 & 0,40 & 2,50 & 2,90 & 3,00 & 1,57 & 1,57 & 1,71 \\
\hline Materiais suspensão orgânicos $\left(\mathrm{mgL}^{-1}\right)$ & 1,44 & 4,50 & 25,33 & 26,33 & 6,80 & 2,08 & 2,80 & 0,72 & 7,80 & 6,10 & 5,70 & 1,00 & 2,14 & 2,86 \\
\hline alcalinidade $\left(\mathrm{mgL}^{-1}\right)$ & 8 & 13 & 40 & 44 & 51 & 9 & 5 & 14 & 7 & 7 & 7 & 10 & 9 & 13 \\
\hline dureza $\left(\mathrm{mgL}^{-1}\right)$ & 8 & 8 & 28 & 28 & 30 & 6 & 2 & 12 & 6 & 4 & 4 & 6 & 6 & 8 \\
\hline Cálcio $\left(\mathrm{mgL}^{-1}\right)$ & 2,57 & 7,50 & 24,70 & 21,00 & 20,80 & 7,15 & 6,10 & 10,00 & 6,35 & 6,04 & 5,60 & 6,47 & 6,90 & 7,36 \\
\hline Magnésio $\left(\mathrm{mgL}^{-1}\right)$ & 0,82 & 0,84 & 0,92 & 0,93 & 1,03 & 0,90 & 0,21 & 0,98 & 0,42 & 0,53 & 0,32 & 0,49 & 0,44 & 0,53 \\
\hline Sódio $\left(\mathrm{mgL}^{-1}\right)$ & 1,00 & 0,90 & 8,50 & 8,80 & 9,20 & 1,20 & 0,50 & 1,10 & 1,00 & 0,70 & 1,00 & 0,90 & 0,90 & 1,70 \\
\hline Potássio $\left(\mathrm{mgL}^{-1}\right)$ & 1,60 & 1,20 & 3,00 & 3,80 & 4,00 & 2,60 & 0,60 & 0,90 & 1,30 & 0,90 & 1,00 & 0,80 & 0,90 & 1,10 \\
\hline Bicarbonatos $\left(\mathrm{mgL}^{-1}\right)$ & 8,00 & 13,00 & 40,00 & 44,00 & 51,00 & 9,00 & 5,00 & 14,00 & 7,00 & 7,00 & 7,00 & 10,00 & 9,00 & 13,00 \\
\hline Sulfatos $\left(\mathrm{mgL}^{-1}\right)$ & 10,00 & 13,00 & 17,00 & 13,00 & 11,00 & 10,00 & 2,00 & 2,00 & 2,00 & 1,00 & 1,00 & 1,00 & 1,00 & 1,00 \\
\hline Cloretos $\left(\mathrm{mgL}^{-1}\right)$ & 0,80 & 0,80 & 5,80 & 8,00 & 9,60 & 2,80 & 1,00 & 29,00 & 1,40 & 1,00 & 3,40 & 1,20 & 1,00 & 1,70 \\
\hline $\mathrm{DQO}\left(\mathrm{mgL}^{-1}\right)$ & 6 & 6 & 54 & 46 & 22 & 9 & 4 & 4 & * & 6 & 4 & 1 & 4 & 4 \\
\hline $\mathrm{DBO} 5\left(\mathrm{mgL}^{-1}\right)$ & * & * & 24 & 19 & 11 & * & * & * & * & * & * & * & * & * \\
\hline Nitrogênio Kjeldahl $\left(\mathrm{ugL}^{-1}\right)$ & 2000 & 3200 & 3200 & 5600 & 1980 & 5600 & 800 & 800 & 3200 & 900 & 800 & 1200 & 1980 & 1380 \\
\hline Fosfato Total $\left(\mathrm{ugL}^{-1}\right)$ & 210 & 202 & 1230 & 1550 & 1570 & 210 & 220 & 195 & 330 & 230 & 220 & 260 & 200 & 340 \\
\hline Ion amônio (ugL $\left.\mathrm{L}^{-1}\right)$ & 76 & 154 & 3100 & 2470 & 1540 & 195 & 50 & 95 & 90 & 60 & 80 & 310 & 80 & 360 \\
\hline Nitrito $\left(\mathrm{ugL}^{-1}\right)$ & 4 & 4 & 7 & 4 & 70 & 2 & 2 & 2 & 4 & 3 & 2 & 2 & 2 & 8 \\
\hline Nitrato $\left(\mathrm{ugL}^{-1}\right)$ & 890 & 230 & 780 & 690 & 720 & 930 & 258 & 480 & 489 & 357 & 360 & 850 & 920 & 440 \\
\hline
\end{tabular}

* Dados não analisados 
Tabela I (Capítulo 4). Concentração de metais na água $\left(\mathrm{mgL}^{-1}\right)$, em março/99 (Ch) e agosto/99 (Es), na bacia do Alto Jacaré-Guaçu

\begin{tabular}{|c|c|c|c|c|c|c|c|c|c|c|c|c|c|c|c|}
\hline Metal & $\begin{array}{l}\text { Ponto } \\
\text { Período }\end{array}$ & M1 & M2 & M3 & M4 & M5 & F1 & F2 & F3 & F4 & F5 & J1 & $\mathrm{J} 2$ & J3 & J4 \\
\hline$\overline{\mathrm{Ag}}$ & $\begin{array}{l}\text { Ch } \\
\text { Es }\end{array}$ & 0,005 & 0,005 & & & 0,005 & 0,008 & 0,005 & 0,008 & 0,005 & 0,005 & & & & \\
\hline $\mathrm{Cd}$ & $\begin{array}{l}\text { Ch } \\
\text { Es }\end{array}$ & & & & & & & & & & & & & & \\
\hline Co & $\begin{array}{l}\text { Ch } \\
\text { Es }\end{array}$ & 0,005 & 0,005 & & & 0,006 & 0,005 & 0,006 & 0,005 & 0,006 & 0,006 & & & & \\
\hline $\mathrm{Cr}$ & $\begin{array}{l}\text { Ch } \\
\text { Es }\end{array}$ & & & & & & & & & & & & & & \\
\hline $\mathrm{Cu}$ & $\begin{array}{l}\text { Ch } \\
\text { Es }\end{array}$ & 0,039 & 0,041 & & & 0,044 & 0,040 & 0,038 & 0,033 & 0,043 & 0,035 & & & & \\
\hline $\mathrm{Fe}$ & $\begin{array}{l}\text { Ch } \\
\text { Es }\end{array}$ & $\begin{array}{c}1.319 \\
0,06\end{array}$ & $\begin{array}{c}3.625 \\
0,8\end{array}$ & 4,23 & 5,2 & $\begin{array}{c}5.319 \\
6,6\end{array}$ & $\begin{array}{c}1.425 \\
0,1\end{array}$ & $\begin{array}{c}2.656 \\
0,48\end{array}$ & $\begin{array}{c}1.550 \\
0,27\end{array}$ & $\begin{array}{c}4.644 \\
0,91\end{array}$ & $\begin{array}{c}3.656 \\
1,75\end{array}$ & 0,88 & 0,52 & 0,70 & 0,70 \\
\hline $\mathrm{Mn}$ & $\begin{array}{l}\text { Ch } \\
\text { Es }\end{array}$ & $\begin{array}{c}0,008 \\
0,05\end{array}$ & $\begin{array}{c}0,044 \\
0,03\end{array}$ & 0,11 & 0,12 & $\begin{array}{c}0,058 \\
0,23\end{array}$ & $\begin{array}{c}0,041 \\
0,02\end{array}$ & $\begin{array}{c}0,016 \\
0,02\end{array}$ & $\begin{array}{c}0,036 \\
0,03\end{array}$ & 0,063 & 0,009 & & & & \\
\hline $\mathrm{Ni}$ & $\begin{array}{l}\mathrm{Ch} \\
\mathrm{Es}\end{array}$ & & & & & & & 0,001 & & & & & & & \\
\hline $\mathrm{Pb}$ & $\begin{array}{l}\text { Ch } \\
\text { Es }\end{array}$ & 0,004 & 0,001 & & & 0,005 & 0,003 & 0,003 & 0,003 & 0,004 & 0,003 & & & & \\
\hline $\mathrm{Zn}$ & $\begin{array}{l}\text { Ch } \\
\text { Es }\end{array}$ & 0,065 & 0,03 & 0,14 & 0,15 & $\begin{array}{c}0,044 \\
0,26 \\
\end{array}$ & 0,031 & 0,030 & 0,044 & 0,038 & 0,028 & & & & \\
\hline
\end{tabular}


Tabela II (Capítulo 4). Concentração de metais biodisponiveis no sedimento ( $\left.\mathrm{mgL}^{-1}\right)$, em março/99 (Ch) e agosto/99 (Es), na bacia do Alto Jacaré-Guaçu

\begin{tabular}{|c|c|c|c|c|c|c|c|c|c|c|c|c|c|c|c|}
\hline Metal & $\begin{array}{l}\text { Ponto } \\
\text { Período } \\
\end{array}$ & M1 & M2 & M3 & M4 & M5 & F1 & F2 & $\mathrm{S} 1$ & L1 & F3 & $\mathrm{J} 1$ & $\mathrm{~J} 2$ & J3 & $J 4$ \\
\hline \multirow[t]{2}{*}{$\overline{\mathrm{Ag}}$} & Ch & 0,73 & 0,91 & & & 0,72 & 0,67 & 0,76 & 0,75 & 0,89 & 0,69 & & & & \\
\hline & Es & 1,14 & 0,88 & 0,89 & 1,11 & 0,76 & 1,04 & 1,01 & 0,85 & 0,96 & 0,78 & 0,95 & 0,58 & 1,05 & 0,76 \\
\hline \multirow[t]{2}{*}{ Co } & Ch & 1,10 & 2,94 & & & 1,44 & 1,01 & 0,91 & 2,26 & 1,33 & 7,41 & & & & \\
\hline & Es & & & & & & & & 1,49 & 0,19 & 10,93 & & & & \\
\hline \multirow[t]{2}{*}{$\mathrm{Cr}$} & Ch & & & & & & & & & & & & & & \\
\hline & Es & & 0,35 & & & & & & & & 0,39 & & & & \\
\hline \multirow[t]{2}{*}{$\mathrm{Cu}$} & Ch & 1,83 & 6,34 & & & 1,80 & 1,34 & 1,09 & 3,38 & 1,33 & 5,86 & & & & \\
\hline & Es & 9,32 & 7,71 & 6,93 & 10,48 & 9,87 & 1,04 & 1,01 & 8,72 & 7,70 & 4,88 & 1,14 & 0,81 & 2,31 & 1,52 \\
\hline \multirow[t]{2}{*}{$\mathrm{Fe}$} & Ch & 362 & 936 & & & 388 & 81 & 184 & 223 & 174 & 2099 & & & & \\
\hline & Es & 768 & 845 & 413 & 914 & 882 & 520 & 261 & 1117 & 737 & 3025 & 455 & 429 & 1306 & 838 \\
\hline \multirow[t]{2}{*}{$\mathrm{Mn}$} & $\mathrm{Ch}$ & 5 & 87 & & & 17 & 17 & 7 & 27 & 27 & 308 & & & & \\
\hline & Es & 17 & 32 & 12 & 19 & 75 & 203 & 25 & 133 & 106 & 220 & 66 & 61 & 157 & 86 \\
\hline \multirow[t]{2}{*}{$\mathrm{Ni}$} & Ch & & & & & & & & & & & & & & \\
\hline & Es & 1,59 & 1,23 & 1,78 & 2,01 & 1,52 & 1,25 & 1,01 & 2,55 & 0,96 & 2,15 & 1,14 & 0,58 & 1,26 & 1,33 \\
\hline \multirow[t]{2}{*}{$\mathrm{Pb}$} & Ch & 0,55 & 0,68 & & & 0,54 & 0,50 & 0,36 & 0,19 & 0,22 & 1,03 & & & & \\
\hline & Es & 1,59 & 1,23 & 1,42 & 2,23 & 1,52 & 1,87 & 1,01 & 1,06 & 1,16 & 1,95 & 0,95 & 0,46 & 1,26 & 0,95 \\
\hline \multirow[t]{2}{*}{$\mathrm{Zn}$} & Ch & 0,73 & 24,89 & & & 3,06 & 1,17 & 0,54 & 1,13 & 0,67 & 8,49 & & & & \\
\hline & Es & 2,96 & 2,45 & 8,53 & 8,03 & 5,31 & 1,46 & 1,21 & 2,34 & 1,54 & 7,03 & 1,71 & 1,04 & 3,15 & 2,10 \\
\hline
\end{tabular}


TABELA I (Capítulo 5). Concentração de pesticidas na água $\left(\mathrm{mgL}^{-1}\right)$, em março/99 (Ch) e agosto/99 (Es), na bacia do Alto Jacaré-Guaçu.

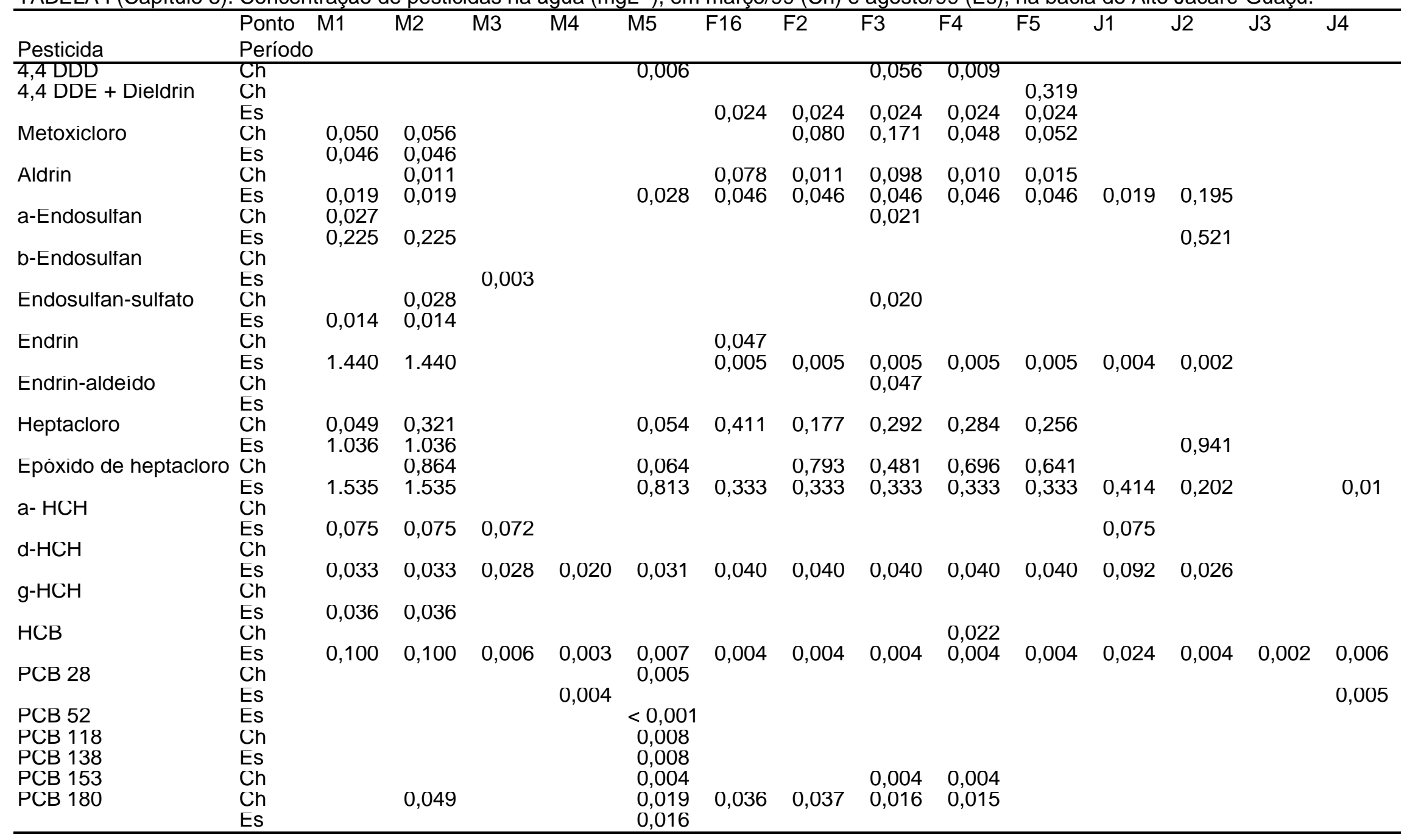


Tabela IX. (Capítulo 6).Classes de dominância dos diferentes táxons, nas chuvas (Ch) e na Estiagem (Es), coletados na bacia.

\begin{tabular}{|c|c|c|c|c|c|c|c|c|c|c|c|c|c|c|c|c|c|c|c|c|c|c|}
\hline \multirow[t]{2}{*}{ Grupo taxonômico } & \multicolumn{2}{|c|}{ M1 } & \multicolumn{2}{|c|}{ M2 } & \multicolumn{4}{|c|}{ M3 M4 M5 } & \multicolumn{2}{|c|}{$\mathrm{F} 1$} & \multicolumn{2}{|c|}{$\mathrm{F} 2$} & \multicolumn{2}{|c|}{ F3 } & \multicolumn{2}{|c|}{$\mathrm{F} 4$} & \multicolumn{2}{|c|}{$\mathrm{F} 5$} & \multicolumn{4}{|c|}{$\begin{array}{lll}\mathrm{J} 1 & \mathrm{~J} 2 & \mathrm{~J} 3 \\
\end{array}$} \\
\hline & $\mathrm{Ch}$ & Es & $\mathrm{Ch}$ & Es & $\mathrm{Es}$ & Es & $\mathrm{Ch}$ & $\mathrm{Es}$ & $\mathrm{Ch}$ & Es & $\mathrm{Ch}$ & Es & $\mathrm{Ch}$ & Es & $\mathrm{Ch}$ & $\mathrm{Es}$ & $\mathrm{Ch}$ & Es & Es & $\mathrm{Es}$ & Es & Es \\
\hline \multicolumn{23}{|l|}{ Clinotanypus } \\
\hline \multicolumn{23}{|l|}{ Fittkauimyia } \\
\hline \multicolumn{23}{|l|}{ Ablabesmyia } \\
\hline \multicolumn{23}{|l|}{ Labrundinia } \\
\hline \multicolumn{23}{|l|}{ Larsia } \\
\hline \multicolumn{23}{|l|}{ Pentaneura } \\
\hline \multicolumn{23}{|l|}{ Djalmabatista } \\
\hline \multicolumn{23}{|l|}{ Procladius } \\
\hline \multicolumn{23}{|l|}{ Apedilum } \\
\hline \multicolumn{23}{|l|}{ Chironomus decorus } \\
\hline \multicolumn{23}{|l|}{ Cryptochironomus } \\
\hline \multicolumn{23}{|l|}{$\begin{array}{l}\text { Goeldichironomus } \\
\text { holoprasinus }\end{array}$} \\
\hline \multicolumn{23}{|l|}{ Harnischia } \\
\hline \multicolumn{23}{|l|}{ Prox. Harnischia } \\
\hline Nilothauma & & & & & & & & & & & & & & & & & & & & & & \\
\hline Parachironomus & & & & & & & & & & & & & & & & & & & & & & \\
\hline Paratendipes & & & & & & & & & & & & & & & & & & & & & & \\
\hline Polypedilum (Poly) sp & & & & & & & & & & & & & & & & & & & & & & \\
\hline Polypedilum (Trip) $s p$ & & & & & & & & & & & & & & & & & & & & & & \\
\hline Saetheria (?) & & & & & & & & & & & & & & & & & & & & & & \\
\hline Nimbocera & & & & & & & & & & & & & & & & & & & & & & \\
\hline Rheotanytarsus & & & & & & & & & & & & & & & & & & & & & & \\
\hline Stempellinela & & & & & & & & & & & & & & & & & & & & & & \\
\hline Tanytarsus & & & & & & & & & & & & & & & & & & & & & & \\
\hline TanytarsiniGênero $B$ & & & & & & & & & & & & & & & & & & & & & & \\
\hline
\end{tabular}




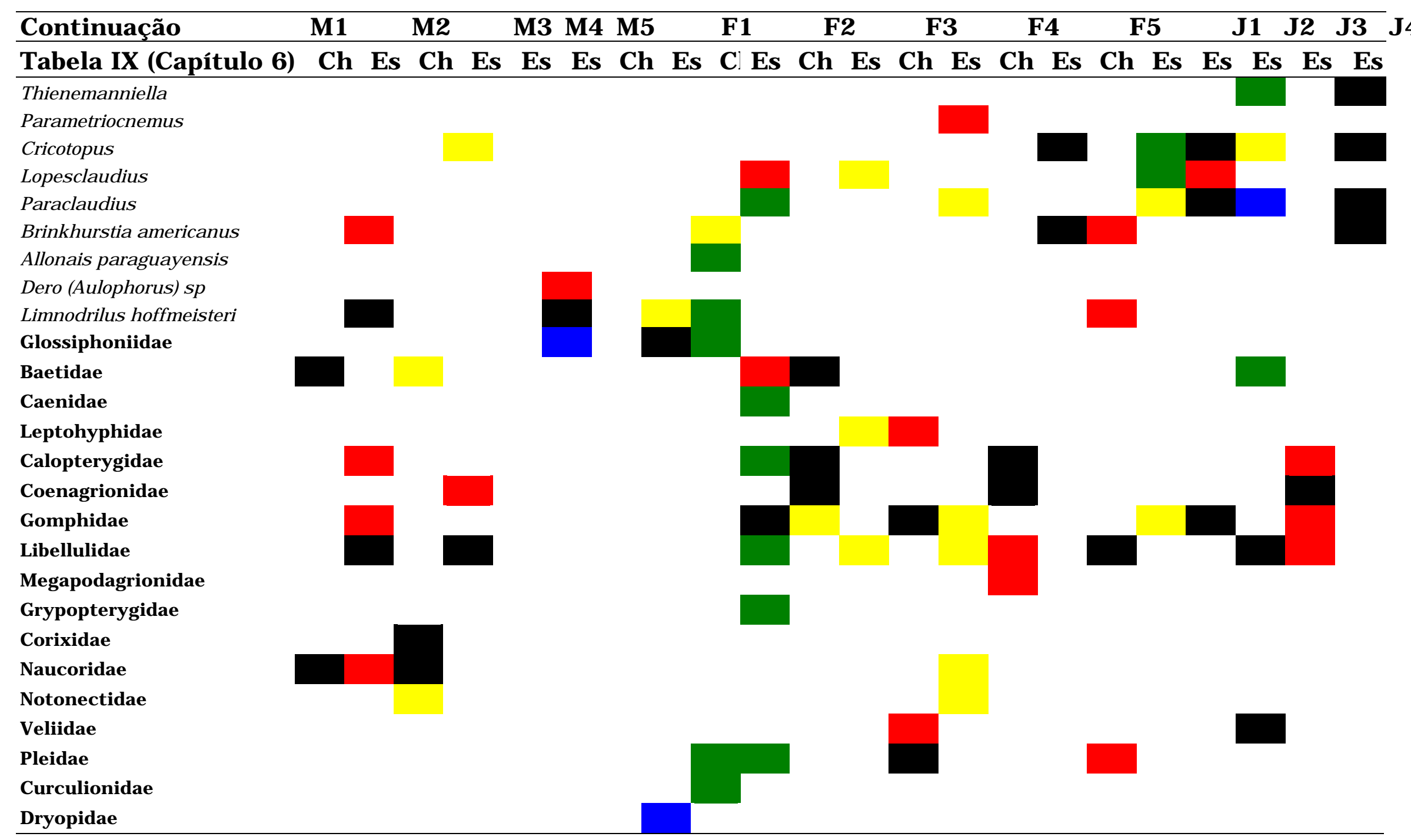




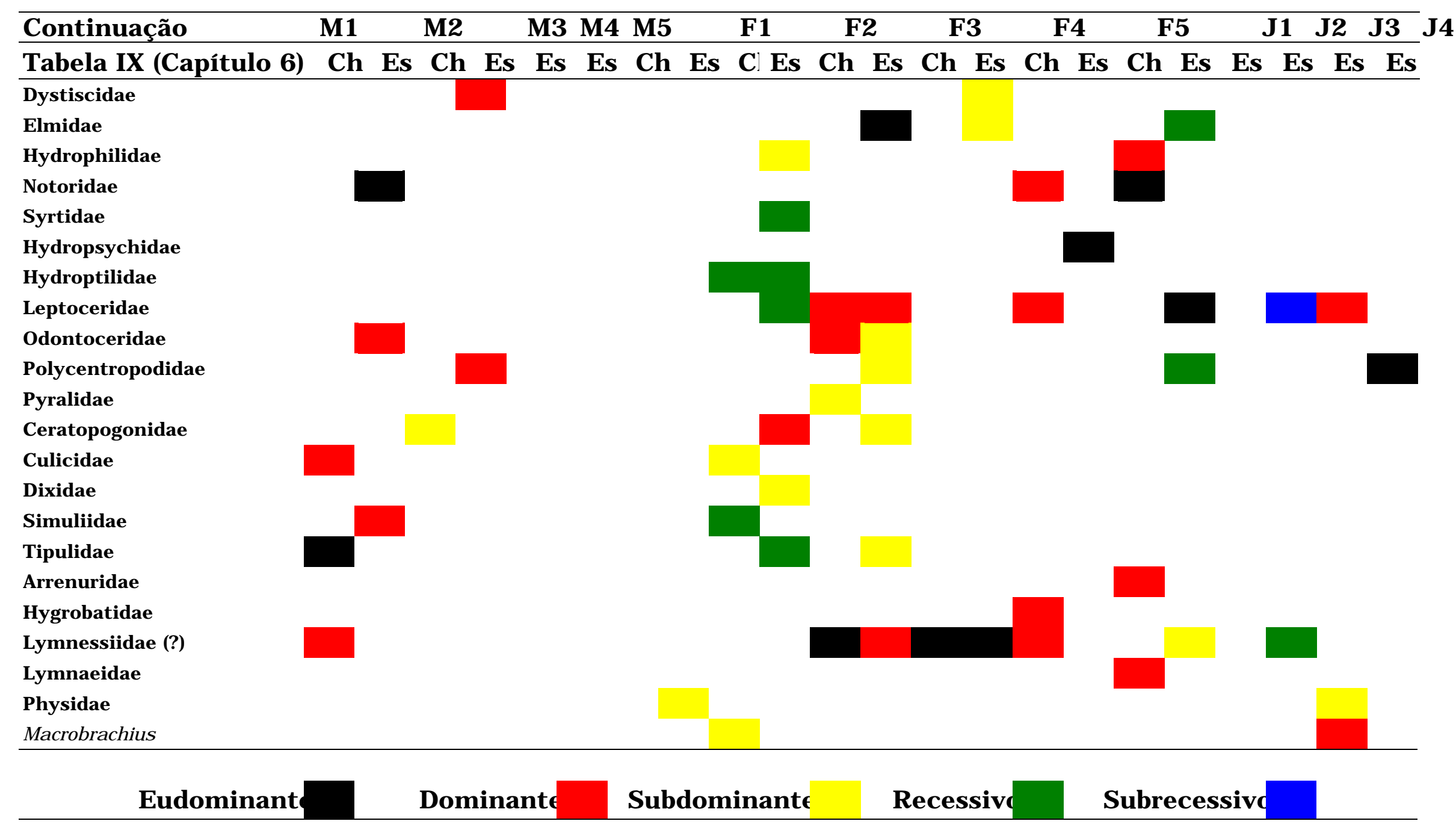

